UNIVERSIDADE DE SÃO PAULO

FACULDADE DE FILOSOFIA, LETRAS E CIÊNCIAS HUMANAS DEPARTAMENTO DE LETRAS ORIENTAIS

PROGRAMA DE PÓS-GRADUAÇÃO EM ESTUDOS JUDAICOS E ÁRABES

PAULA DA COSTA CAFFARO

PARA UMA PADRONIZAÇÃO EM PORTUGUÊS DA TERMINOLOGIA MORFOSSINTÁTICA DO VERBO ÁRABE

VERSÃO CORRIGIDA

"De acordo" do orientador:

Orientadora: Prof ${ }^{a} \mathrm{Dr}^{\mathrm{a}}$ Safa Alferd Abou Chahla Jubran

SÃO PAULO

2012 


\title{
PARA UMA PADRONIZAÇÃO EM PORTUGUÊS DA TERMINOLOGIA MORFOSSINTÁTICA DO VERBO ÁRABE
}

\begin{abstract}
Dissertação apresentada ao Programa de Pós-Graduação em Estudos Judaicos e Árabes, do Departamento de Letras Orientais da Faculdade de Filosofia, Letras e Ciências Humanas da Universidade de São Paulo, para a obtenção do título de Mestre em Estudos Árabes.
\end{abstract}

Área de Concentração: Estudos Árabes

Orientadora: Prof ${ }^{\mathrm{a}} \mathrm{Dr}^{\mathrm{a}}$ Safa Alferd Abou Chahla Jubran

BANCA EXAMINADORA

Prof $^{a}$ Dr $^{a}$ Safa Alferd Abou Chahla Jubran

Instituição: USP - FFLCH

Presidente

Prof $^{\mathrm{a}} \mathrm{Dr}^{\mathrm{a}}$ Paola Giustina Baccin

Instituição: USP - FFLCH

Titular

Prof. Dr. João Baptista de Medeiros Vargens

Instituição: UFRJ - Faculdade de Letras - Externo

Titular 


\section{DEDICATÓRIA}

A Deus, por me sustentar nos momentos em que minhas forças já não eram mais suficientes e por estar sempre ao meu lado.

A minha amada mãe, por seu apoio incondicional e por suas ternas palavras que acalentam meu coração.

A minha querida irmã, por sua presença amiga em minha vida.

A meus avós, Juarez e Pedrina, pelo acolhimento e por serem um exemplo para mim. 


\section{AGRADECIMENTOS}

Começo estes agradecimentos, louvando a Deus pelo fim de mais esta importante etapa em minha vida acadêmica e profissional. Agradeço ao Senhor por toda capacitação, inspiração e graça concedida durante este árduo período de estudos.

Agradeço a minha orientadora, $\operatorname{Dr}^{\mathrm{a}}$ Safa Jubran, que me aceitou sem nem mesmo me conhecer. Obrigada por ter confiado em mim e ter me dado uma oportunidade de desabrochar academicamente. Agradeço sua hospitalidade genuinamente árabe, por me acolher e me guiar nos momentos em que eu não conseguia perceber o melhor caminho a seguir. Obrigada por me ajudar a lidar com a ansiedade, um desafio para mim, e a me ensinar que a pesquisa precisa ser gerada dentro de nós até que floresça. Obrigada por sua amizade, incentivo e carinho.

Agradeço aos membros da banca examinadora, porque mesmo de longe, acompanharam meu desenvolvimento.

Agradeço aos meus colegas e amigos "uspianos", tão comprometidos com a pesquisa e o saber. Obrigada pelo exemplo, companheirismo, simpatia, amizade e apoio. Agradeço, em especial, à Rita de Cássia Gomes, Amanda Aziz, Wafa Hage, Elias Mendes, Rafael Minussi (e aos colegas do DL), a todos os colegas do Departamento de Letras Orientais e aos amigos do Grupo de Orientalismos na História.

Aproveito o ensejo, para agradecer a Mamede Jarouche, Michel Sleiman, Mona Hawi, Miguel Attie Filho, Arlene Clemesha, caríssimos professores dos Estudos Árabes da USP. Obrigada pela disponibilidade nos momentos de dúvida, pelo empenho e amor à causa. Muito aprendi com vocês.

Não poderia deixar de mencionar meus amigos e professores da Universidade Federal do Rio de Janeiro, minha primeira casa. Agradeço ao Monsenhor Alphonse Nagib Sabbagh, nosso Abuna, por ser nosso referencial e mestre incansável na busca pelo saber. Com 93 anos de idade, ainda encontra disposição e ânimo para novos projetos conjuntos. Realmente, nosso maior exemplo.

Agradeço ao Prof. Dr. João Baptista, por me acompanhar em toda minha trajetória acadêmica, desde a época da graduação, passando por Damasco, Rio de 
Janeiro, São Paulo, Itaboraí, Tanguá, Rio Bonito. Sua presença tutorial e amiga me traz segurança e confiança de que sou capaz, de que posso ir além.

Obrigada Sueli Lima, Geni Harb, Cristiane Duarte, Bianca Graziela pela amizade, companheirismo, orientação, incentivo. É muito bom ter vocês em minha vida.

Agradeço aos professores Hani Hazime e Ibrahim G. Khalil por me convencerem a não abandonar o curso de árabe ainda no princípio da graduação.

Agradeço a Rafael Lopes, caro colega e técnico de TI, por me ajudar e orientar quando as ferramentas tecnológicas falharam e o desespero de perder todo meu trabalho tomou conta de mim.

Agradeço à CAPES (Coordenação de Aperfeiçoamento de Pessoal de Ensino Superior), pela concessão da bolsa de mestrado e pelo suporte financeiro para realização desta pesquisa.

Agradeço ao apoio irrestrito da minha família e de meus familiares, vocês são minha base. Agradeço, em especial, a meu primo Vitor Caffaro, que antes de mim cruzou a Dutra rumo a São Paulo e fixou moradia. Obrigada pela acolhida e pelo cuidado quando eu também fui cidadã paulistana.

Agradeço aos meus verdadeiros amigos, por compreenderem minhas ausências por causa dos estudos, por me incentivarem mesmo admirados com minha escolha, por se orgulharem de mim e de meu trajeto.

Obrigada a todos que compõem minha história e contribuem para quem sou hoje. 
"A vida é uma peça de teatro que não permite ensaios. Por isso, cante, chore, dance, ria e viva intensamente, antes que a cortina se feche e a peça termine sem aplausos."

\section{Charles Chaplin}

"Tudo tem seu tempo. Há um momento oportuno para cada coisa debaixo do céu: tempo para plantar e tempo para colher (...)"

Eclesiastes, 3, 1 . 
CAFFARO, Paula da C. Para uma padronização em português da terminologia morfossintática do verbo árabe. 158 f. Dissertação (Mestrado) - Departamento de Letras Orientais - Programa de Pós-Graduação em Estudos Judaicos e Árabes. Faculdade de Filosofia, Letras e Ciências Humanas, Universidade de São Paulo, São Paulo, 2012.

\section{RESUMO}

Este trabalho consiste na investigação da terminologia gramatical árabe, visando à padronização em língua portuguesa. Tendo em vista a grande quantidade dos fenômenos linguísticos, a análise restringiu-se às denominações da classe verbal. Dez termos principais e dezesseis termos secundários foram investigados em três corpora constituídos de gramáticas árabe-árabes; gramáticas árabes elaboradas por arabistas e de obras de referência cujo tema é a terminologia gramatical árabe. O objetivo principal desta pesquisa é propor uma padronização em português da terminologia morfossintática do verbo árabe que seja aparente aos leitores especializados brasileiros, a priori, e aos pesquisadores lusófonos cujo objeto de estudo seja a língua árabe. Elabora-se ainda um glossário terminológico Árabe-Português/ Português-Árabe.

Palavras-chave: Língua árabe, Verbo árabe, Língua portuguesa, Terminologia Gramatical. 
CAFFARO, Paula da C. For a standardization in Portuguese of the morphosynthatic terminology of the Arabic verb. $158 \mathrm{f}$. Thesis (Masters Degree) Departamento de Letras Orientais - Programa de Pós-Graduação em Estudos Judaicos e Árabes. Faculdade de Filosofia, Letras e Ciências Humanas, Universidade de São Paulo, São Paulo, 2012.

\section{ABSTRACT}

This work consists of an investigation of Arabic grammatical terminology, aiming at the standardization in Portuguese language. In view of the great amount of linguistic phenomena, the analysis was restricted to the verbal class names. Ten principal terms and sixteen secondary terms were investigated in three corpora constituted by Arabic-Arabic Grammars; Arabic Grammar elaborated by Arabists and other reference works on Arabic Grammatical Terms. The main aim of this search is to suggest standardization in Portuguese of the morphosynthatic terminology of the Arabic verb which can be understandable to Brazilian skilled readers, at first, to Lusophone searchers whose study objective is Arabic language. It is elaborated a Terminological Glossary Arabic-Portuguese/ Portuguese-Arabic.

Key Words: Arabic language, Arabic verb, Portuguese language, Grammatical terminology. 
CAFFARO, Paula da C. توحيدُ مُصطََحاتِ الفِعْل العَرَبيّ النَّحَويّة والصَّرْفيّة في اللُّفة البرتغاليّة 158 f. بَحْبُ المَجِنْتِنِ - Departamento de Letras Orientais - Programa de Pós-Graduação em Estudos Judaicos e Árabes. Faculdade de Filosofia, Letras e Ciências Humanas, Universidade de São Paulo, São Paulo, 2012.

\section{الإخِتصار}

هذا العمل هو تحقيق للمصطلحات النحوية العربية، ويهذف إلى توحيد المصطلحات في اللغة البرتغالية. نظرا لكثرة الظواهر اللغوية، يقتصر الدرس على اسماء الأفعال. عشر مصطلحات أساسية وستة عشر مصطلح ثانوي. وكان التحقيق في ثلاثة مجاميع مكونة من "كتب قواعد عربية-عربية؛ كتب قواعد الّقها مستعربون ومراجع هدفها المصطلحات النحوية العربية". أما الهدف الرئيسي لهذا البحث هو الاشارة الى توحيد المصطلحات النحوية الصرفية للافعال العربية كي تكون مفهومة بدئيا من قبل القراء المتخصصين البرازيلين ومن ثم من قبل الباحثين الناطقين باللغة البرتغالية الهادفين لدرس اللغة العربية في اللغة البرتغالية. وقام البحث ايضا بوضع معجم مصطلحات عربية-برتغالية وبرتغالية-عربية.

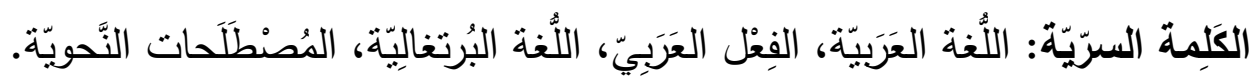


A TRANSLITERAÇÃO ADOTADA NESTA DISSERTAÇÃO' ${ }^{1}$ :

\begin{tabular}{|c|c|c|}
\hline Grafema árabe & Transliteração & Transcrição Fonética \\
\hline 1 & $\overline{\mathrm{a}}$ & /a:/ \\
\hline ب ب & $\mathrm{b}$ & $/ \mathrm{b} /$ \\
\hline ت ت ت ت & $\mathrm{t}$ & $/ \mathrm{t} /$ \\
\hline ث & $\underline{\mathrm{t}}$ & $/ \theta /$ \\
\hline ج & $\mathrm{j}$ & $/ 3 /$ \\
\hline$\tau$ & ḥ & $/ \mathbf{h} /$ \\
\hline$\dot{\tau}$ & $\underline{h}$ & $/ \mathrm{x} /$ \\
\hline د & d & $/ \mathrm{d} /$ \\
\hline$\dot{j}$ & $\underline{\mathrm{d}}$ & $/ \mathrm{d} /$ \\
\hline J & $\mathrm{r}$ & $/ \mathrm{r} /$ \\
\hline j & $\mathrm{z}$ & $\mid \mathrm{z} /$ \\
\hline س & $\mathrm{s}$ & $/ \mathrm{s} /$ \\
\hline ش & $\check{s}$ & $/ 2 /$ \\
\hline ص & ș & $|s|$ \\
\hline ض & $\bar{d}$ & $/ \mathrm{d} /$ \\
\hline b & $t$ & $|k|$ \\
\hline ظ & $\underline{\mathrm{d}}$ & $\mid \mathrm{A} /$ \\
\hline$\varepsilon$ & $\mathrm{c}$ & $/ \Omega /$ \\
\hline$\dot{\varepsilon}$ & $\dot{\mathrm{g}}$ & $|\gamma|$ \\
\hline ف & $\mathrm{f}$ & $/ \mathrm{f} /$ \\
\hline ق ق & $\mathrm{q}$ & $/ \mathrm{q} /$ \\
\hline
\end{tabular}

\footnotetext{
${ }^{1}$ As palavras árabes transliteradas que aparecerem nas citações ao longo deste trabalho serão adaptadas segundo a convenção acima adotada.
} 


\begin{tabular}{|c|c|c|}
\hline 5) & $\mathrm{k}$ & $/ \mathrm{k} /$ \\
\hline J & 1 & $/ 1 /$ \\
\hline s & $\mathrm{m}$ & $/ \mathrm{m} /$ \\
\hline$\dot{ن}$ & $\mathrm{n}$ & $/ \mathrm{n} /$ \\
\hline ه & $\mathrm{h}$ & $/ \mathrm{h} /$ \\
\hline \multirow{2}{*}{9} & $\overline{\mathrm{u}}$ (vogal longa) & /u:/ \\
\hline & w (semiconsoante) & $/ \mathrm{w} /$ \\
\hline \multirow[b]{2}{*}{ ي } & $\overline{1}($ vogal longa $)$ & /i:/ \\
\hline & y (semiconsoante) & $/ \mathrm{j} /$ \\
\hline $\mathcal{G}$ & à & /a:/ \\
\hline$\varepsilon$ & , & $/ 2 /$ \\
\hline$\ddot{0}$ & $\begin{array}{l}\mathrm{t} \text { (quando pronunciado } \\
\text { entre duas vogais }{ }^{2} \text { ) }\end{array}$ & $/ \mathrm{t} /$ \\
\hline- & $\mathrm{u}($ vogal breve $)$ & $/ \mathrm{u} /$ \\
\hline- & a (vogal breve) & $/ \mathrm{a} /$ \\
\hline$=$ & i (vogal breve) & /i/ \\
\hline
\end{tabular}

\footnotetext{
${ }^{2}$ Quando não pronunciado, ao final de palavras, não será transliterado.
} 


\begin{tabular}{|c|c|}
\hline NÚMERO & DENOMINAÇÃO \\
\hline Tabela 1 & Níveis de atualização da língua \\
\hline Tabela 2 & Campos das fichas terminológicas \\
\hline Tabela 3 & Termos investigados \\
\hline Tabela 4 & Conjugação do verbo jجََ jalasa \\
\hline Tabela 5 & $\begin{array}{l}\text { Tabela ilustrativa do paradigma facala } \\
y a f i l u \text {, cujo } w \bar{a} w \text { é a primeira radical }\end{array}$ \\
\hline Tabela 6 & Tipologia das raízes verbais árabes \\
\hline Tabela 7 & $\begin{array}{l}\text { Conceitos de tempo, aspecto e modo } \\
\text { verbal }\end{array}$ \\
\hline Tabela 8 & $\begin{array}{c}\text { Semelhanças e diferenças entre a voz } \\
\text { ativa/ passiva árabe e portuguesa }\end{array}$ \\
\hline Tabela 9 & $\begin{array}{c}\text { Semelhanças entre 'afäl nāqișa, verbo } \\
\text { defectivo e verbo de ligação }\end{array}$ \\
\hline Tabela 10 & Raiz, radical e afixo em árabe e português \\
\hline Tabela 11 & 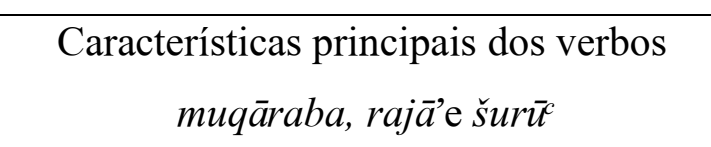 \\
\hline Tabela 12 & Verbos madh e damm \\
\hline
\end{tabular}


INTRODUÇÃO

CAPÍTULO I: DA TERMINOLOGIA, DA TERMINOGRAFIA, DA LEXICOLOGIA,DA LEXICOGRAFIA......................................................

1 Da Terminologia e seus objetos de estudo ............................................. 04

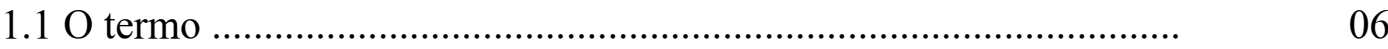

1.2 A fraseologia ................................................................................. 08

1.2 A definição terminológica ............................................................

2 Da Terminografia ..............................................................................

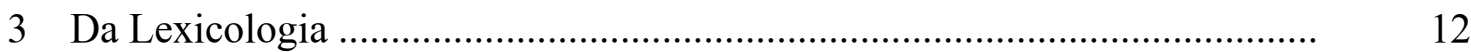

4 Da Lexicografia ......................................................................... 14

5 Obras de referência: dicionário de língua, dicionário terminológico, glossário

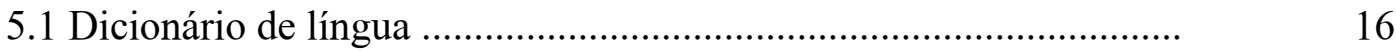

5.2 Dicionário terminológico ................................................................ 17

5.3 Glossário ....................................................................................

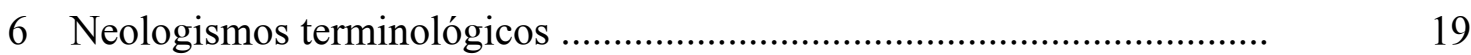

CAPÍTULO II: DA METODOLOGIA DE TRABALHO ........................... 23

CAPÍTULO III: ANÁLISE E DISCUSSÃO DOS TERMOS ...................... 33

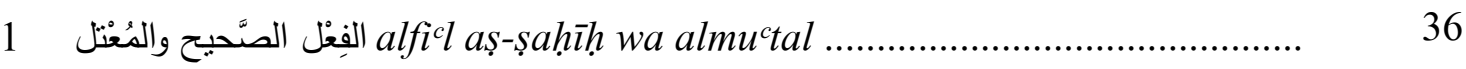

1.1 صَّيح

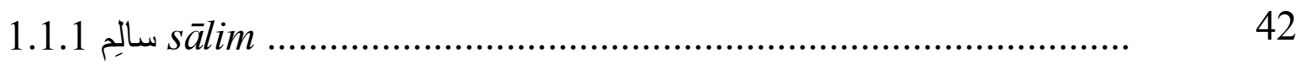

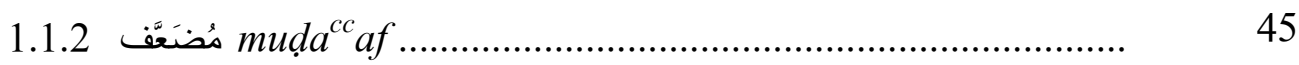

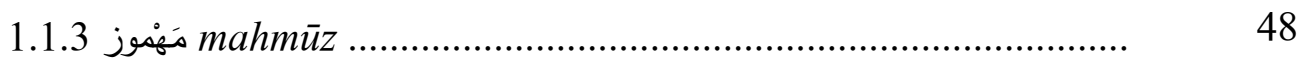

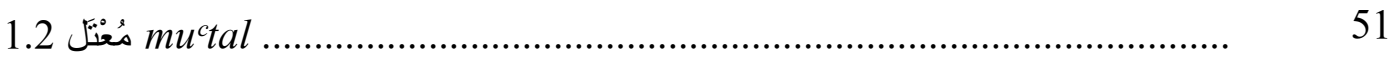

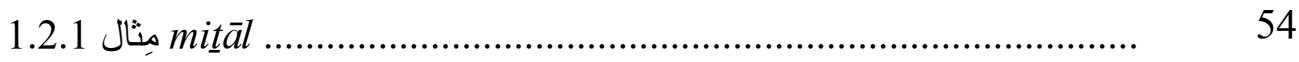

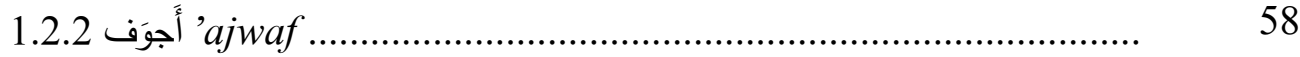




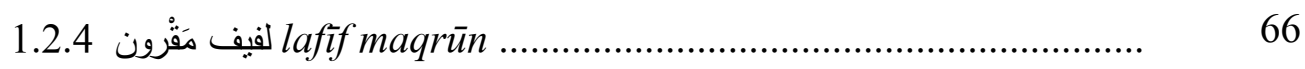

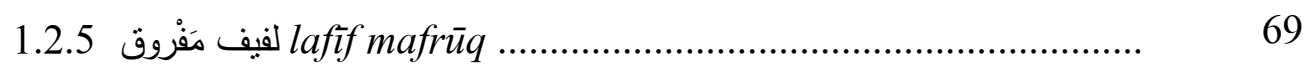

2 O tempo, o aspecto e o modo verbal: um panorama .............................. 71

2.1 الفِعْل الماضي alficl almād

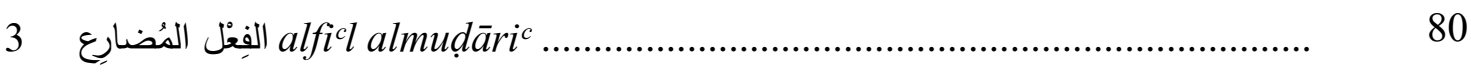

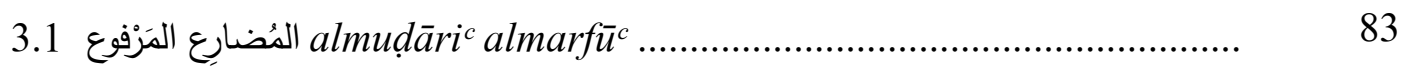

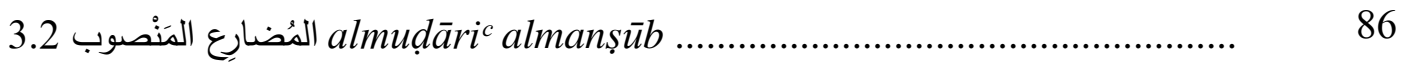

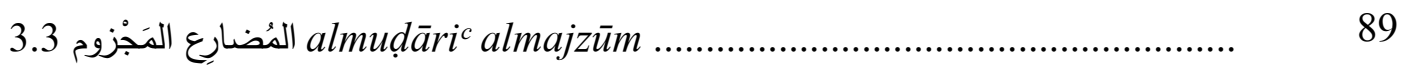

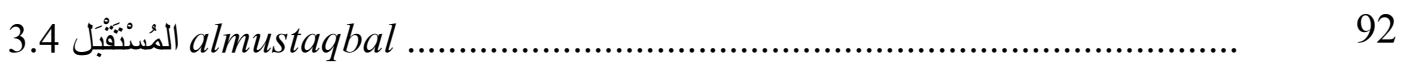

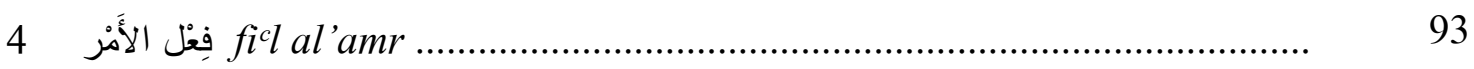

5 Os verbos $l \bar{a} z i m$ e mutac $^{c} a d d i n$ e a transitividade verbal ........................... 94

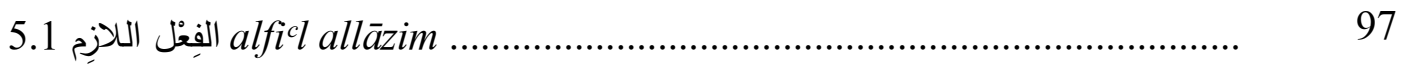

5.2 الفِعْل المُنَتَدَّي 100

$6 \quad$ A voz do verbo árabe e português: categorias correspondentes? ............... 102

6.1 الفِعْل المَبْني لِلْمَعْلوم alficl almabnī lil-maclūm .......................................... 107

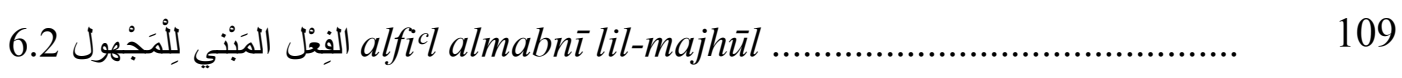

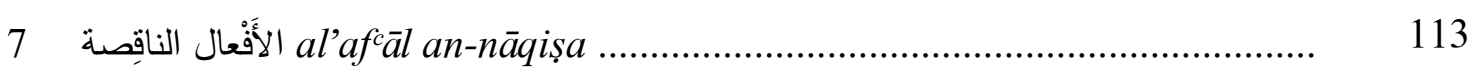

$8 \quad 120$

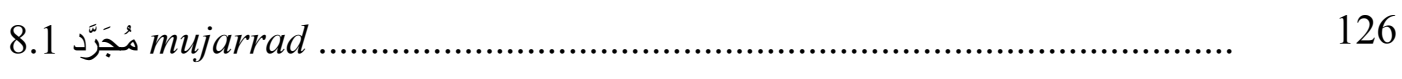

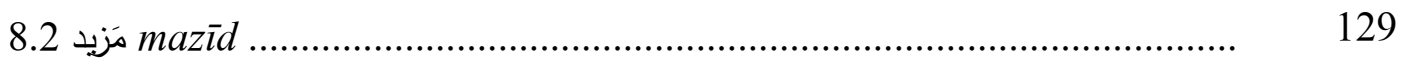

$9 \quad 131$

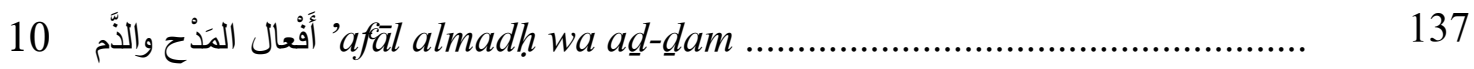

CAPÍTULO IV: GLOSSÁRIO DA TERMINOLOGIA VERBAL MORFOSSINTÁTICA .................................................................................. 141

1. Glossário Árabe-Português da Terminologia Verbal Morfossintática ....... 143 
2. Glossário Português-Árabe da Terminologia Verbal Morfossintática ........ 145

CONSIDERAÇÕES FINAIS ................................................................. 147

REFERÊNCIAS BIBLIOGRÁFICAS ......................................................... 152 


\section{INTRODUÇÃO}

A importância de se estudarem as terminologias gramaticais foi observada ainda em sala de aula durante a graduação, quando o ensino da gramática árabe causava quase um desconforto entre professor/aluno, não devido aos pontos gramaticais apresentados, mas pelas denominações, em língua vernácula, atribuídas aos processos linguísticos. Uma linguagem hermética e pouco aparente não favorece a compreensão para quem não é "iniciado" ou apenas iniciante no assunto (Krieger \& Finatto, 2004, p. 67). Como exemplo da afirmação acima, tem-se o termo árabe ’iḍăfa, referido comumente em português pelo termo "anexação". Esta terminologia não evoca nenhuma associação de ideias ou de estruturas existentes na língua portuguesa que guie o entendimento do aluno.

A fim de desenvolver o estudo das terminologias, pensou-se em focalizar as denominações do verbo. Devido à grande quantidade de fenômenos linguísticos da língua árabe, assim como de qualquer língua, foi necessário que se restringuisse o escopo, e, para esta primeira fase de pesquisas, o mestrado, procuram-se discutir as terminologias aplicadas à classe verbal. A escolha foi motivada, também, pelo interesse pessoal da pesquisadora, que possui por esta classe maior interesse.

Ao reunir todos os termos verbais, verificou-se que estes foram elaborados em bases que versavam majoritariamente sobre a morfologia e a sintaxe dos verbos. Há, contudo, termos ligados à semântica e à fonética dos mesmos. Esta mistura de critérios tem origem na classificação depreendida pelos primeiros gramáticos árabes, os quais sistematizaram e compilaram as regras gramaticais e sua terminologia em fins do século VIII e princípio do IX, sendo Sībawayhi ${ }^{1}$ (morte em 793) o principal ícone deste processo. Ao longo dos séculos, os gramáticos árabes optaram pela simplificação de certos aspectos gramaticais e de sua terminologia, em relação ao Árabe Clássico (objeto de estudo e descrição dos primeiros gramáticos), dando início ao Árabe Moderno Padrão (objeto deste trabalho), no entanto, tal mistura de critérios classificatórios

\footnotetext{
${ }^{1}$ Conhecido como "o pai da gramática árabe", Sībawayhi escreveu o primeiro tratado gramatical árabe de valor imensurável para a tradição linguística. Publicado apenas após sua morte e, por isso deixada sem título, ficou conhecida como Alkitāb, "O Livro".
} 
permaneceu, sendo exaustivamente reproduzida nas gramáticas modernas escritas por árabes e não árabes.

Dez termos verbais foram selecionados para esta pesquisa, os quais se desdobram em outros termos secundários também considerados, totalizando uma lista final de vinte e seis itens a serem investigados em três corpora principais. O primeiro corpus é formado por quatro gramáticas árabe-árabe; o segundo compõe-se de sete gramáticas árabes elaboradas por arabistas de nacionalidades e épocas diferentes, e o terceiro, por três obras de referência cujo tema é a terminologia gramatical árabe.

O objetivo desta dissertação é investigar os vinte e seis termos nos três corpora supracitados e verificar:

1. o comportamento gramatical de cada item, observando a coerência com a terminologia adotada pelos gramáticos árabes;

2. as opções terminológicas de cada gramático não árabe para designar, em suas línguas de chegada, os termos estudados, averiguando se foram provenientes de traduções literais ou fruto de reflexões linguísticas;

3. se há padronização entre os termos adotados pelos gramáticos não árabes e se esta é pertinente ao leitor especializado brasileiro;

4. se é possível estabelecer algum paralelo biunívoco entre o processo gramatical árabe e português, a fim de se buscar termos correspondentes em ambas as línguas ${ }^{2}$.

Quando for constatado que a padronização terminológica existente não é aparente ao leitor brasileiro ou quando não houver correspondência gramatical entre termos árabes e portugueses, são sugeridos novos termos que deem conta do item em estudo.

Assim, este é um exemplo de trabalho terminológico cujo objetivo principal consiste em instrumentalizar a comunidade especialista deste domínio do saber, a fim de garantir que o fluxo comunicacional seja preciso e isento de ambiguidades. Portanto, o propósito central deste trabalho é auxiliar o leitor especializado brasileiro na compreensão dos termos gramaticais do verbo árabe e propor uma padronização destas

\footnotetext{
${ }^{2}$ A pesquisa sobre os processos linguísticos portugueses será extraída de um quarto corpus, composto por cinco gramáticas e um dicionário de linguística e gramática portuguesa.
} 
terminologias as quais serão sistematizadas em um glossário ÁrabePortuguês/Português-Árabe.

Destarte, o Capítulo I traz uma revisão da literatura quanto aos conceitos da Terminologia, Terminografia, Lexicologia e Lexicografia e suas interseções conceituais. Enfoca-se, ainda no primeiro capítulo, os objetos de estudo da Terminologia, a diferenciação entre três obras de referência, a saber, o dicionário de língua, o terminológico e o glossário, seguida da justificativa pela escolha deste último tipo para sistematizar o produto da análise, e um breve resumo sobre os neologismos terminológicos devido à necessidade de criação de novas palavras ao longo da pesquisa.

O Capítulo II ocupou-se em explicar a metodologia adotada neste trabalho. Antes de delinear os caminhos metodológicos, os seguintes aspectos técnicos foram esclarecidos: o objetivo, o público alvo, os limites da pesquisa, a delimitação da nomenclatura e a organização interna do glossário. Ainda neste capítulo, foram apresentadas as justificativas de escolha das sete gramáticas não árabes, as três fichas terminológicas e os critérios de tratamento dos termos.

No Capítulo III, dá-se a análise dos vinte e seis termos. Cada item é analisado segundo as determinações previstas pela metodologia. A padronização em português da terminologia morfossintática do verbo árabe, fruto deste trabalho terminológico, será sistematizada no glossário Árabe-Português/Português-Árabe, presente no Capítulo IV, e por fim, tecem-se algumas considerações finais. 


\section{CAPÍTULO I}

\section{Da Terminologia, da Terminografia, da Lexicologia, da Lexicografia}

Fazer terminologia repetimos, continuamente, não é, por exemplo, traduzir. A unidade de tradução não é, de forma alguma, a unidade terminológica, e, portanto, fazer uma pesquisa terminológica bilíngue não é partir de uma nomenclatura preestabelecida em uma dada língua por um dicionário e traduzir para outra selecionando palavras semanticamente equivalentes. A qualidade de um trabalho terminológico pressupõe a descrição de uso e só, posteriormente, a avaliação da conveniência da denominação. - (nosso grifo)

Maria Teresa Cabré ${ }^{3}$

\section{Da Terminologia e seus objetos de estudo}

A Terminologia é a disciplina que estuda cientificamente o léxico de natureza técnica, científica e especializada (léxico temático ou especializado) que constitui as linguagens de especialidade ${ }^{4}$.

A Terminologia, compreendida como o estudo científico, teve suas bases estabelecidas na segunda metade do século XX, pelo engenheiro austríaco Eugen Wüster $^{5}$ (1898-1977), que a introduziu na Universidade de Viena em 1972, contudo, o uso das terminologias não é um fenômeno recente. Este remonta ao tempo em que o homem começou a utilizar a linguagem para expressar conceitos dos mais variados domínios de conhecimento e a denominá-los (cf. Krieger \& Finatto, 2004, p. 16).

Especialistas apontam para a já conhecida polissemia do termo terminologia, que, nas palavras de Maciel (2001b, p. 40) "paradoxalmente contradiz o ideal de univocidade perseguido por sua própria teoria tradicional", uma vez que pode expressar

\footnotetext{
${ }^{3}$ Fragmento extraído do prefácio do livro Curso Básico de Terminologia (Barros, 2004, p. 17).

${ }^{4}$ Segundo Pavel \& Nolet (2002 apud Barros, 2004, p. 42), linguagem de especialidade constitui um "sistema de comunicação oral ou escrito usado por uma comunidade de especialistas de uma área particular do conhecimento".

${ }^{5}$ Eugen Wüster, considerado o fundador da Terminologia moderna, lecionou na Universidade de Viena de 1972 a 1974, como professor honorário ligado ao Departamento de Linguística Geral e Aplicada, onde ministrou o curso Introdução à Teoria Geral da Terminologia e à Lexicografia Terminológica. (Barros, 2004, p. 54)
} 
tanto a disciplina ou campo de estudos teórico e aplicado do léxico especializado como indicar o conjunto de termos de uma área específica ${ }^{6}$.

Em seu artigo Terminologia: conceitos e aplicações, Augusto Dias (2000, p. 90) apresenta a seguinte citação de Sager (1998) que resume, de maneira sucinta, o que é Terminologia em sua perspectiva poliédrica. Sager afirma que:

[...] como teoria, terminologia é um conjunto de premissas, argumentos e conclusões necessário para explicar o relacionamento entre conceitos e termos especializados; como prática, é um conjunto de métodos e atividades voltado para coleta, descrição, processamento e apresentação de termos; como produto, é um conjunto de termos, ou vocabulário, de determinada área."

O objetivo principal da Terminologia, a nosso ver, está em instrumentalizar a comunidade especialista de determinado domínio do saber a fim de garantir que o fluxo comunicacional seja preciso, conciso, adequado e sem ambiguidades. Para tal, estuda-se cientificamente o léxico especializado, organizando e harmonizando as noções (conceitos) ou conjunto de noções dos domínios específicos do conhecimento (Cintra et al., 2001, p. 21). Por isso, a Terminologia tradicional, também conhecida por Teoria Geral da Terminologia (TGT), formulada por Eugen Wüster, empenhava-se no estudo terminológico com o objetivo de normativização ${ }^{7}$, sendo seu princípio motor a busca pela univocidade entre o conceito e o termo. Com o avanço das pesquisas terminológicas, um paradigma alternativo surgiu, tendo como base a visão comunicativa da linguagem em domínios de especialidade. Nesse sentido, a sinonímia, a homonímia, a polissemia e a variação linguística passaram a ser previstos.

O objetivo, nesse novo e alternativo paradigma (ou a Teoria Comunicativa da Terminologia) ${ }^{8}$, deslocou-se da prescrição de termos anterior para a descrição formal, semântica e funcional das unidades linguísticas que podem adquirir o valor

\footnotetext{
${ }^{6}$ A fim de evitar ambiguidades, será observada a seguinte convenção: um $T$ maiúsculo para referir-se ao campo de estudos e um $t$ minúsculo para designar o conjunto de termos.

${ }^{7} \mathrm{O}$ termo "normatizar" será adotado no sentido prescritivo, da imposição de formas caracterizadas pelo conceito fluido de "bom-uso", requerida pelas autoridades organizacionais que tratam da Terminologia em seus documentos prescritivos. (Demai, 2006, p. 72) A diferenciação entre "normatizar" e "normalizar" advém de conceitos extraídos da Socioterminologia que considera a língua como fato histórico-social. Tal diferenciação assume função didática no texto. Pretende-se com isso discriminar entre o caráter prescritivo e descritivo.

${ }^{8}$ Este paradigma alternativo foi proposto por Maria Teresa Cabré, chama-se Teoria Comunicativa da Terminologia (TCT).
} 
terminológico, suas relações sígnicas com outras unidades da língua e como fazem progredir o conhecimento especializado (Cabré 1999b apud Barros, 2004, p.59).

Ressalte-se que, nessa nova perspectiva da Terminologia, importa normalizar, isto é, fazer uma descrição prévia do uso terminológico seguida da padronização e sistematização dos termos, levando em conta a variação linguística, conforme salienta Faulstich "um dos parâmetros para a normalização é a variação" (1999 apud Demai, 2006, p. 72).

Observa-se que, mesmo com o amadurecimento das teorias terminológicas, a preocupação com a padronização, sistematização e harmonização das terminologias manteve-se constante, visto ser esse um dos mecanismos que garantirá a eficácia da comunicação entre os especialistas. Demai (2006, p. 42) declara que "a Terminologia tem o poder - e o dever - de normalização dos termos, [...]". Vale à pena ressaltar que, qualquer tentativa de normalização das terminologias não deve ser artificial ou imposta, ao contrário, deve ser refletida por especialistas que, em situação ideal, trabalhem em cooperação com o terminólogo.

A Terminologia possui três objetos de estudo, a saber, o termo, a fraseologia e a definição terminológica. Krieger \& Finatto (2004, p. 22) afirmam que tanto a descrição e explicação destes objetos quanto o conjunto de diretrizes metodológicas para o tratamento dos mesmos configura a identidade da disciplina em foco.

\section{$1.1 \mathrm{O}$ termo}

O termo é a unidade padrão de análise da Terminologia. Trata-se das unidades lexicais técnicas com as quais o leitor se depara em um texto técnico, científico ou de alguma área de especialidade. Os termos revelam a especialização do campo de conhecimento e caracterizam a linguagem de especialidade. A função do termo é essencialmente referencial dentro de um sistema de conceitos (Maciel, 2001, p. 276).

Devido à diversidade de definições encontradas para a unidade terminológica que varia de acordo com a perspectiva teórica de cada autor, decidiu-se apresentar três visões do que venha a ser um termo a fim de se chegar a um denominador comum.

A primeira é a versão registrada pelos organismos internacionais de normalização, definindo o termo como uma "designação, por meio de uma unidade linguística, de um conceito, definida em uma língua de especialidade" (ISO 1087 apud 
Barros, 2004, p. 40), é, portanto, uma unidade lexical com um conteúdo específico dentro de um campo específico.

A segunda trata-se da definição de Wüster. Esta afirma que "uma unidade terminológica consiste em uma palavra à qual se atribui um conceito como seu significado (...)" (Wüster, 1998 apud Krieger \& Finatto, 2004, p. 76). Para o autor, o conceito é o componente responsável pela atribuição do estatuto de termo a uma unidade lexical. O termo, na TGT, é uma unidade de conhecimento. A diferenciação entre palavra e termo está fundamentada no conteúdo especializado de sua dimensão conceitual.

A terceira visão reflete a perspectiva da Teoria Comunicacional da Terminologia (TCT), que define o termo como sendo uma palavra "ativada singularmente por suas condições pragmáticas de adequação a um tipo de comunicação" (Cabré, 1999a apud Barros, 2004, p. 41). Isto quer dizer que as unidades linguísticas só se tornam termos quando são empregadas em textos de especialidade, o que ratifica o argumento de que os termos são unidades lexicais das línguas naturais. Assim, é o contexto especializado que seleciona o conteúdo específico das unidades lexicais.

Observando as três proposições acima, nota-se que o fator determinante para o estatuto terminológico é sua dimensão conceitual (Krieger, 2001, p. 122). Mesmo na consideração da TCT, é a acepção específica selecionada que faz de uma unidade lexical um termo, integrando-a a um campo de especialidade.

É importante chamar a atenção, também, para a dupla dimensão dos termos, que compreendem tanto uma dimensão cognitiva, por expressarem conhecimentos especializados, quanto uma dimensão linguística, por constituírem o léxico temático ou especializado das línguas (Krieger \& Finatto, 2004, p. 16). Dupla também é sua função, pois, ao mesmo tempo em que representam os conceitos e sua estruturação - função cognitiva, eles transmitem os conteúdos próprios de cada área do saber - função comunicativa. Os termos podem ter estrutura simples ou sintagmática (sintagma terminológico).

Os termos em estudo nesta dissertação, cuja área de especialidade é a morfossintaxe verbal árabe, serão enfocados na perspectiva textual-discursiva desenvolvida a partir dos estudos de Maria Teresa Cabré. Para esta visão, os termos compõem o léxico geral da língua, tendo seu conteúdo específico selecionado de acordo com o contexto discursivo em que estão inseridos. 


\subsection{A fraseologia}

As fraseologias são expressões recorrentes tanto nas comunicações gerais, quanto nas especializadas. São estruturas complexas que podem ser definidas como "conjuntos de unidades pluriverbais lexicalizadas e frequentes na comunicação" (Ettiger, 1982 apud Krieger \& Finatto, 2004, p. 84) e representam os compostos, os provérbios, as expressões idiomáticas e as locuções, por exemplo.

O interesse da Terminologia pela fraseologia especializada pode ser considerado recente, como afirmam Krieger \& Finatto (2004, p. 84), manifestando-se, principalmente, devido a sua frequência nas comunicações especializadas e a seu vínculo semântico com os conteúdos em voga. Coexistem com os termos num sistema de complementaridade de expressão e conteúdos de uma área específica.

Há duas tendências principais quanto à conceituação de fraseologia, cuja descrição encontra-se em Krieger \& Finatto (2004, p. 86-90). A primeira define as unidades fraseológicas como colocações, isto é, combinações pluriverbais fixas ou semifixas, formadas basicamente por duas unidades léxicas, como, por exemplo, anulação de contrato. Nesta tendência, em que se sobrepõe o critério formal de prevalência sintática, a fraseologia aproxima-se do sintagma terminológico. A segunda as define como fórmulas ou frases feitas, próprias de determinado campo de especialidade, por exemplo, para efeitos da lei, sendo também chamada de extralinguística, pois importa mais as relações com a área de conhecimento do que os aspectos morfossintáticos dos elementos formantes das estruturas fraseológicas.

Observa-se a preocupação, nas pesquisas atuais, quanto à delimitação das fronteiras entre termo, do tipo sintagmático (o sintagma terminológico) e a fraseologia devido à semelhança de configuração, como, por exemplo, expressa na estrutura com elemento deverbal absorção de energia. Há estudos hoje, que buscam identificá-los e descrevê-los, apesar da complexidade do tema. A título de exemplificação, cita-se o trabalho de Borges (2001, p. 430) "Identificação de sintagmas terminológicos em Geociências", no qual a autora relata que "a grande maioria dos termos identificados para a composição de um dicionário bilíngue em Geociências apresentava a estrutura sintagmática do tipo (...) nome + preposição + nome e nome + adjetivo”. Seus resultados levaram-na a comprovar a hipótese de que a criação dos sintagmas terminológicos é motivada por categorias semânticas próprias dos diferentes domínios 
do conhecimento. Outra conclusão a que a autora chegou refere-se à predominância da constituição morfológica dos sintagmas. Segundo ela, predomina a forma nome + adjetivo. Da mesma maneira, dentre os termos investigados nesta pesquisa, há a predominância das estruturas sintagmáticas nome + adjetivo e nome + preposição + nome, assim como há fraseologias especializadas, porém, em menor número.

Não constitui interesse, deste trabalho, delinear os contornos mais profundos da fraseologia especializada, importa-nos apenas conceituar e justificar sua inserção no quadro dos objetos de estudo da Terminologia.

\subsection{A definição terminológica}

A definição terminológica, doravante DT, constitui o último objeto de estudo da Terminologia. Particulariza-se por sua função delimitadora do enunciado-texto, que procura dar conta dos significados de termos e expressões especializadas, transmitindo os conceitos de uma área de conhecimento em situação comunicacional. Conforme afirmam Krieger \& Finatto (2004, p. 93), para haver uma boa formulação da DT, é imprescindível que tanto o gênero próximo ${ }^{9}$ como a diferença específica deem conta, juntos, da delimitação e singularidade do conceito expresso, de modo que tal definição seja aplicada apenas àquele conjunto de entes.

A DT é um elemento fundamental na formação e veiculação do conhecimento técnico, científico e especializado, por isso, passou a ser um foco de interesse das pesquisas terminológicas. Krieger \& Finatto (2004, p. 95) atestam que

[...] pela definição é possível observar tanto a linguagem quanto o conhecimento especializado num processo de evolução e alteração, evidenciando a DT como elemento de sustentação tanto para as terminologias quanto para as linguagens especializadas em geral.

\footnotetext{
${ }^{9}$ Tanto o gênero próximo quanto a diferença específica são categorias aristotélicas, sendo a primeira definida como "[...] a parte da definição que expressa a categoria ou a classe geral a que pertence o ente definido", e a segunda descrita como "[...] a indicação da(s) particularidade(s) que distingue(m) esse ente em relação a outros de uma mesma classe.” (Krieger \& Finatto 2004, p. 93)
} 
Finatto (2001b, p. 288-292) expõe como é concebida a DT em duas escolas com perspectivas diferentes, a primeira possui uma visão mais linguística, é representada por Sager, A. Rey e Cabré, e, a segunda, com uma visão menos linguística, representada por Wüster e seus sucessores.

Na primeira escola de pensamento, Sager afirma que a DT é a descrição linguística de um conceito que dá conta de seu significado; Rey, por sua vez, acrescenta que a DT difere das demais definições por reunir a definição lexicográfica e a descrição enciclopédica, evocando o conceito; Cabré endossa que a DT é um enunciado que descreve uma noção dentro de um sistema nocional, diferenciando-a de outras noções. O ponto de encontro entre esses autores é a aproximação entre a dimensão linguística e a dimensão do conhecimento especializado. No mesmo texto citado, Finatto destaca a posição de Rey, afirmando que a DT, em sua expressão linguística, apenas evoca o conceito, sem representá-lo diretamente.

Wüster considera a definição como uma descrição de um conceito, a descrição do significado de uma designação (o termo). Este autor justifica a interferência de estudiosos em favor do desenvolvimento consciente das terminologias, daí, prevê uma descrição prescritiva, diferenciando-a da primeira, da seguinte forma: "as definições descritivas mostram como as coisas são, e as prescritivas, como deveriam ser" (Finatto, 2001b, p. 290), no entanto, este posicionamento gera problemas quanto à fidelidade na representação dos conceitos da linguagem natural.

Outro representante desta visão citado por Finatto é Weissenhoff, para quem "a DT deve oferecer uma delimitação estrita e uma definição precisa do conceito para tornar a comunicação tão eficiente e tão sem ambiguidades quanto possível" (Finatto, 2001b, p. 290). Weissenhoff reconhece que, longe do imobilismo lógico-matemático, a DT é fortemente condicionada pela natureza do domínio em que se insere.

Nesta visão menos linguística, segundo Finatto (2001b, p. 291) há a tentativa de isolar o processo definitório ${ }^{10}$ do processo de conceituação ${ }^{11}$, como se fosse possível encontrar conceitos expressos ou representados fora de uma representação linguística.

\footnotetext{
${ }^{10}$ A definição pertence ao nível semiótico, resultado da análise e descrição das grandezas sígnicas, da interpretação das unidades lexicais; definir, por sua vez, consiste na análise e descrição do semema linguístico para construir o mundo mental, partindo da estrutura linguística (processo semasiológico). (Barbosa 2001, p. 77)
} 
Em outra pesquisa acerca das definições terminológicas, Finatto (2001a, p. 434-435) evidenciou que, desde os estudos clássicos da Filosofia, Retórica e Lógica, a constituição e estrutura da DT tem sido apreciada em função da presença ou ausência das categorias aristotélicas de gênero próximo e diferença específica. Esses padrões foram sendo reinterpretados na literatura, deixando de ser grandezas referenciais, passando a valores lógicos essenciais.

Ao longo de nossa pesquisa, não será necessário formular definições terminológicas para cada termo selecionado, posto que todas serão extraídas do corpus em estudo, a saber, as gramáticas árabes e não árabes relacionadas.

\section{Da Terminografia}

A Terminografia constitui a face aplicada da Terminologia, é a chamada "prática de elaboração de vocabulários". Ela compila sistematicamente termos que figuram no universo de uma área especializada e cria uma obra onde os mesmos ficarão registrados, disponibilizando informações linguísticas e conceituais. A aplicação prática da Terminografia volta-se à produção de glossários, dicionários técnicos ou terminológicos e banco de dados.

Silva (2009, p. 51) destaca alguns objetivos práticos da Terminografia:

(a) A identificação de terminologias, (b) reconhecimento da variedade de suas formas, tanto no plano linguístico e semiótico, (c) os princípios de análise do funcionamento dos termos com intenção de serem registrados como instrumento de referência especializado.

Ainda segundo Silva, os estudos terminográficos auxiliam na produção dos fundamentos teóricos e metodológicos para a aplicação prática nas obras de referência. Os estudos terminográficos buscam verificar a funcionalidade da obra produzida, a adequação das definições terminológicas, a pertinência das informações gramaticais, entre outras.

\footnotetext{
${ }^{11} \mathrm{O}$ conceito pertence ao nível pré-linguístico, é resultado da interpretação dos fatos naturais e culturais; conceituar, portanto, constitui o processo de construção de um modelo mental seguida da estrutura léxica, o ponto de partida é o universo. (processo onomasiológico). (Barbosa 2001, p. 76)
} 


\section{Da Lexicologia}

Se a Terminologia é o estudo científico do léxico especializado, a Lexicologia define-se pelo estudo científico do léxico comum, especificamente, das palavras de uma língua. A Lexicologia, portanto, apresenta um escopo mais amplo que a Terminologia visto ocupar-se do componente lexical geral não especializado das línguas.

A unidade padrão da Terminologia é o termo e a da Lexicologia é o lexema ${ }^{12}$, caracterizada pela inseparabilidade entre significado e significante, assim como proposto por Ferdinand Saussure (2006). Na teoria defendida por Wüster, a unidade terminológica não segue o modelo de Saussure. Na TGT, o conceito pode ser tratado independentemente de sua expressão, a prioridade de análise é do conceito, para, apenas em seguida, buscar uma designação correspondente (Barros, 2004, p. 60).

Refletir sobre os níveis de atualização da língua auxilia na compreensão sobre o estatuto científico da Terminologia e da Lexicologia. Os fundamentos para essa reflexão remontam à dicotomia saussuriana langue (língua) e parole (fala), em que língua é "o produto social da faculdade da linguagem, e um conjunto de convenções necessárias, adotadas pelo corpo social para permitir o exercício dessa faculdade nos indivíduos" (Saussure, 2006, p.17). Parole (fala) é a parte individual da linguagem, constitui-se de atos individuais, sendo assim múltipla e imprevisível. Esses atos são ilimitados, por isso não formam sistema; trata-se da concretização em discurso da língua.

Louis Hjelmslev (1968) retoma a dicotomia saussuriana língua/fala, opondo-a à outra: sistema/processo. Para o autor, a teoria da linguagem deve verificar a existência de um sistema subjacente a um processo, em suas palavras "a todo processo corresponde um sistema que permite analisá-lo e descrevê-lo por meio de um número restrito de princípios" (Hjelmslev, 1968 apud Barros, 2004, p. 62). O sistema corresponde à língua e o processo constitui as realizações individuais e concretas da língua.

Eugênio Coseriu (1979) constata que a formulação de Hjelmslev não foge à dicotomia saussuriana e inova ao introduzir o nível da norma no modelo precursor. Assim, Coseriu define sistema como o nível mais abstrato de atualização da língua

\footnotetext{
${ }^{12}$ Lexema, ou lexia, é a unidade de conteúdo de uma língua, de acordo com a classificação de Pottier (Demai, 2006, p. 38) pode ser simples (formado de um único lexema ou lexemas afixados), composto (formado por dois lexemas) ou complexo (formado por sintagma fixo).
} 
funcional ${ }^{13}$. Trata-se de um conjunto estruturado de possibilidades do qual o falante deve servir-se no momento da enunciação (Baccin, 2003, p.63). Tais possibilidades de escolhas são infinitas, desde que o caráter funcional (as características obrigatórias deste nível) seja respeitado.

Quanto à norma, Coseriu define ser as "estruturas simplesmente normais e tradicionais na comunidade" (Coseriu, 1979 apud Barros, 2004, p. 63). Representa as convenções do grupo no qual o falante está inserido, e impõe-se ao enunciador no momento da fala. Segundo Baccin (2003, p.64) "a norma consiste em um conjunto de realizações obrigatórias, implicitamente definidas por um grupo social, geográfica profissional ou culturalmente delimitado, utilizadas apenas no âmbito desse grupo". Ferir a norma de determinado grupo, seja ele representado por adolescentes, acadêmicos ou agricultores, constitui-se em um desvio das convenções daquele grupo de falantes, embora não comprometa a compreensão da mensagem, desde que o caráter funcional do sistema não seja afetado.

O falar concreto de Coseriu não difere da definição de fala saussuriana, isto é, "são os atos linguísticos concretamente registrados no próprio momento de sua produção" (Coseriu, 1979 apud Baccin, 2003, p. 65). Baccin salienta que, no Brasil, se convencionou chamar este nível de discurso, de acordo com a proposição de Mattoso Câmara, com o objetivo de se evitarem mal-entendidos quanto à natureza oral e escrita do falar concreto.

A Tabela abaixo ilustra o desenvolvimento do modelo dos níveis de atualização da língua:

\begin{tabular}{llcc}
\hline & \multicolumn{2}{c}{ Níveis de atualização da língua } \\
\hline Saussure & Língua & Fala \\
Hjelmslev & Sistema & Processo \\
Coseriu & Sistema & Norma(s) & Falar \\
& & concreto/Discurso \\
\hline
\end{tabular}

Tabela 1: Níveis de atualização da língua

\footnotetext{
${ }^{13}$ Segundo Coseriu (1980) apud Baccin (2003, p. 63), "língua funcional é definida como uma técnica linguística determinada (unitária e homogênea), considerada sob o ponto de vista sincrônico (um período historicamente determinado), sintópico (uma única realidade geográfica), sinstrático (um único estrato social) e sinfásico (uma única modalidade expressiva).”
} 
Após a explanação acima, verifica-se que os estudos terminológicos e as linguagens de especialidade situam-se no nível da norma, por tratar das padronizações técnicas, tecnológicas, científicas ou especializadas; e os estudos lexicológicos situamse no nível do sistema (língua geral ou comum).

\section{Da Lexicografia}

Enquanto a Terminografia é a face aplicada da Terminologia, a Lexicografia constitui a interface do léxico geral, sendo responsável pela elaboração de dicionários de língua ou especiais ${ }^{14}$. De acordo com Barbosa (1990 apud Demai, 2006, p. 40)

Em relação à ciência-base Lexicologia, a Lexicografia define-se como ciência-aplicada, cujo objetivo é a produção de dicionários; em relação à prática lexicográfica, a Lexicografia se define como pesquisa fundamental, cujo objeto são as teorias e os modelos de confecção de dicionários.

Assim, à guiza de resumo, podemos dizer que "o léxico de uma língua é a pedra fundamental do estudo de todas as ciências da linguagem: a Lexicologia, a Lexicografia, a Terminologia e a Terminografia", como bem observa Silva (2009, p. 48).

\section{Obras de referência: dicionário de língua, dicionário terminológico e glossário}

Zucchi (2010) define coesa e claramente o que vem a ser uma obra dicionarística:

\footnotetext{
Um dicionário é um texto estruturado num eixo vertical e num eixo horizontal. Existe uma terminologia específica que denomina suas partes. O eixo vertical é formado pelo conjunto de entradas. A entrada é cada unidade lexical - palavra simples, composta, expressões, abreviaturas (dependendo da proposta da obra) - à qual

14 “Dicionários especiais são os dicionários de língua que registram apenas um tipo de unidade lexical ou fraseológica, como, por exemplo, os dicionários de expressões idiomáticas, de provérbios, de ditados, de sinônimos, de antônimos, etc., os quais podem ser monolíngue, bilíngue ou multilíngue." (Barros, 2004, p. 64)
} 
segue o enunciado lexicográfico. O conjunto de entradas é chamado de nomenclatura ou nominata. A forma como é organizada a obra como um todo recebe o nome de macroestrutura. Organização que define a ordem das entradas, de tipo onomasiológico ou semasiológico, a inclusão de tabelas, de símbolos fonéticos, de textos com explicações gramaticais e de uso, de ilustrações, e outros. Já o conjunto de informações que segue cada entrada recebe o nome de microestrutura. A microestrutura é formada pela entrada e pelo enunciado lexicográfico. Zucchi (2010 apud Gomes, 2011, p. 81)

Segundo Barros (2004, p. 133), dicionário ou repertório constitui o modo genérico de chamar as obras lexicográficas - dicionários de língua, dicionários especiais e outros que registrem as unidades lexicais em todas as suas acepções dentro do sistema linguístico; e as obras terminográficas - dicionários terminológicos (ou vocabulários) que contêm o conjunto de termos de um domínio especializado (de uma técnica, uma ciência, uma profissão etc.).

A tipologia dos dicionários depende de muitos fatores. De acordo com Maciel (2001b, p. 42), um fator que influencia o formato de um dicionário é a perspectiva linguística do autor, aliada às necessidades reais, desejos e preferências do usuário da obra, uma vez que "o dicionário é, antes de tudo, a interface discursiva de autor e consulente a partir da proposição de um texto definitório". Além disso, a autora destaca as exigências do mercado editorial e publicitário que, se por um lado, impulsionam a produção de dicionários, por outro, põem entraves e prejudicam a excelência desejada pelos autores.

Silva (2009, p. 52) elenca quatro critérios básicos para a realização e produção de dicionários, (a) o público-alvo; (b) a relevância das informações privilegiadas, de natureza linguística ou extralinguística; (c) a disposição das entradas (se alfabética, isto é, pela forma, ou sistemática, pelo conteúdo); (d) o número de unidades linguísticas que deverão compor a nomenclatura ${ }^{15}$.

Barbosa (2001, p. 26) aponta que não há consenso quanto à delimitação conceitual das obras lexicográficas e terminográficas, apesar das pesquisas avançadas na área e dos organismos normalizadores existentes em diferentes países. Assim, após

\footnotetext{
${ }^{15}$ Se o objetivo da obra for levantar o maior número possível de unidades de uma língua ou de um domínio, então ela será extensiva; contudo, se o propósito for oferecer grande número de informações na microestrutura, neste caso será intensiva.
} 
analisar a proposta de variados autores para conceituação da tipologia dessas obras, a autora mencionada restringe-se à classificação dos três tipos básicos de obras enfocados, correlacionando-as com os três níveis de atualização da língua, de acordo com o modelo de Coseriu (1979): sistema, norma(s) e fala ou discurso.

Barros (2004, p. 143) trilha um percurso de análise semelhante ao realizado por Barbosa (2001), e, apoiando-se nos modelos estudados, apresenta uma proposta própria de classificação tipológica das obras lexicográficas e terminográficas. Os critérios adotados foram: (a) nível de atualização da unidade lexical; (b) presença ou ausência de definições; (c) presença ou ausência de dados enciclopédicos.

A seguir, apresentam-se três modelos e considerações propostos por Maciel (2001), Barbosa (2001) e Barros (2004) sobre os três tipos de obras enfocados, a saber, o dicionário de língua, o dicionário terminológico e o glossário, seguido do posicionamento da presente pesquisa.

\subsection{Dicionário de língua}

O dicionário de língua, segundo Maciel (2001b, p. 42), representa o inventário do léxico comum de uma língua. Sua nomenclatura tende a abarcar a totalidade das unidades lexicais da língua geral, focalizando as formas correntes de sua época de elaboração. Partindo de uma realização padronizada, tal dicionário apresenta todos os significados e usos possíveis da unidade lexical, assim como as formas que a palavra possa assumir, seu paradigma morfológico, campos semânticos, quadro derivacional, níveis de uso, sinônimos e antônimos. Contemplam-se todas as categorias gramaticais, do substantivo à interjeição.

A nomenclatura do dicionário de língua é organizada alfabeticamente e compreende desde formas do uso popular até palavras eruditas. Embora, teoricamente, apenas os termos mais representativos de cada área, os mais importantes e mais divulgados fizessem parte do conjunto de entradas de um dicionário de língua geral, estima-se que mais de 40\% das entradas sejam termos (Landau, 1993 apud Maciel, 2001 b, p. 43). Krieger (2001, p. 124) reitera a assertiva, afirmando que o aumento dos termos em dicionários de língua, isto é, a incorporação das terminologias no léxico geral 
da língua deve-se à larga difusão do conhecimento e sua circulação em amplas esferas comunicacionais.

Segundo Barbosa (2001, p. 33), dicionário de língua é uma obra que se situa no nível do sistema linguístico e contém o conjunto das unidades lexicais de uma língua em todas as suas acepções e contextos.

De acordo com os critérios elencados por Barros (2004, p. 143) e mencionados acima, dicionário de língua situa-se no nível do sistema, lista uma grande quantidade de unidades lexicais ou fraseológicas de uma língua, registrando, também, as diferentes acepções que a palavra possa ter nos inúmeros universos de discurso. Apresenta, obrigatoriamente, definições, mas não dados enciclopédicos.

Observa-se, assim, que há certa homogeneidade quanto à conceituação de dicionário de língua, sendo sua característica principal dar conta do maior número possível de unidades lexicais da língua geral ou comum, registrando as diferentes acepções que essa possa ter nos contextos mais variados.

\subsection{Dicionário terminológico}

O dicionário terminológico é aquele cujas bases de elaboração pautam-se nos princípios teóricos e metodológicos da Terminologia e Terminografia. Para Maciel (2001b, p. 44), o dicionário terminológico é um subgrupo, ao lado do dicionário lexicográfico, dos dicionários técnicos. No dicionário técnico lexicográfico, o termo é um elemento linguístico do vocabulário especializado, já no dicionário terminológico, o termo é um conceito único em um sistema de conceitos específicos. A definição terminológica, conjugando o aspecto lexical e o conceito do termo a sua função comunicativa, pode apresentar dados linguísticos e enciclopédicos. Os exemplos e menção da fonte validam a pertinência temática e pragmática do termo dentro do campo de especialidade.

A nomenclatura do dicionário terminológico inclui expressões complexas, sintagmas, siglas, abreviaturas, fórmulas, nomes próprios, de objetos e até de entidades envolvidos na área repertoriada. A categoria gramatical mais contemplada é a do 
substantivo. A disposição das entradas pode ser por ordem alfabética ou por ordem sistemática, isto é, respeitando o mapa conceitual do domínio estudado.

Para Barbosa (2001, p. 32), o vocabulário (ou dicionário terminológico) situase no nível da norma e recobre um ou mais universos de discurso; o conjunto de termos tratados nessa obra constitui um subconjunto do universo lexical. Nota-se que, dentre os autores estudados por Barbosa, não há uma relação biunívoca entre conceitos e termos na área da tipologia das obras terminográficas, como ilustrado pela variação na terminologia "dicionário terminológico" e "vocabulário" para indicar, basicamente, o mesmo referente - "inventário de termos de um domínio e que descreve os conceitos designados por meio de definições e/ou ilustrações". Há, portanto, variadas denominações para o mesmo núcleo conceitual, como demonstra o exemplo acima, da mesma forma como se encontram conceitos muito diferentes para uma mesma denominação, como, por exemplo, "vocabulário" no sentido de "repertório de termos" e no sentido de "dicionário de uma área".

Barros (2004, p. 144) propõe que o dicionário terminológico (termo tolerado: vocabulário) situe-se no nível da(s) norma(s), registrando unidades terminológicas de um ou vários domínios, apresenta definições, mas nenhum dado enciclopédico. Neste último aspecto, a definição de Barros afasta-se da de Maciel (2001b), pois esta prevê a existência de dados enciclopédicos. Outro aspecto interessante é que, para Barros, “dicionário terminológico" é o termo principal, sendo "vocabulário" o termo tolerado, enquanto que, para Barbosa (2001), "vocabulário" assume o termo principal. Essa diferença ocorre devido aos critérios priorizados por cada autora, fato que conduz à multiplicidade de denominações para o mesmo conceito.

\subsection{Glossário}

Em seu artigo, Maciel (2001b) não investiga o tema "glossário", por isso, passa-se a segunda autora que, antes de apresentar sua proposta de denominação, cita diferentes fontes, nas quais se encontram as seguintes definições básicas para o termo:

(a) Glossário (termo tolerado: vocabulário): dicionário terminológico baseado num trabalho terminológico que apresenta a terminologia de um 
domínio ou de subdomínios ou de vários domínios associados. (tradução da ISO 1087, pela CEETT ${ }^{16}$ )

(b) Denomina-se glossário um dicionário que contém, sob forma de simples definições (ou equivalentes), as significações das palavras raras ou pouco comuns. (Lino at al.s/d apud Barbosa, 2001, p. 30)

(c) Glossário: repertório que define termos de uma área científica ou técnica, dispostos em ordem alfabética, podendo apresentar ou não remissivas. (Faulstich,1995 apud Barbosa, 2001, p. 32)

A visão do termo glossário também não é consensual entre os especialistas de Terminologia/Terminografia, sendo usado para designar tanto um dicionário, vocabulário ou uma coleção de palavras-ocorrência de um discurso, isto é, o léxico de uma obra determinada. Nesse sentido, Barbosa (2001, p. 33) situa glossário no nível da fala, definindo-o como um "repertório que reúne as palavras-ocorrência de um texto específico".

Segundo a proposta de Barros (2004, p. 144), glossário (termo tolerado: dicionário bilíngue, dicionário multilíngue) pode situar-se tanto no nível do sistema como no da(s) norma(s), sua característica principal é não apresentar definições, mas apenas uma lista de unidades lexicais ou terminológicas acompanhadas de seus equivalentes em outras línguas. Esta será, pois, a acepção adotada na presente dissertação, cujo objetivo final é propor um glossário Árabe-Português e PortuguêsÁrabe da terminologia verbal morfossintática árabe, sistematizando uma proposta de padronização em língua portuguesa.

\section{Neologismos terminológicos}

Neologia é o fenômeno de criação de novas unidades lexicais, de acordo com as regras de produção incluídas no sistema lexical vigente (Guilbert, 1975 apud Demai,

\footnotetext{
${ }^{16}$ Grupo de trabalho da Comissão de Estudo Especial Temporária de Terminologia, criada no âmbito do IBICT (Instituto Brasileiro de Informação em Ciência e Tecnologia) /ABNT (Associação Brasileira de Normas Técnicas), (cf. Barbosa, 2001, p. 27)
} 
2004, p. 74). Neologismo, então, consiste no produto deste processo; podendo ocorrer na língua geral ou nas linguagens de especialidade - o neologismo terminológico ${ }^{17}$.

Alves (2001, p. 54) estabelece que o neologismo trata-se de "uma unidade lexical de criação recente, uma acepção nova atribuída a um elemento existente, ou então, uma unidade recebida de um outro código". Segundo Boulanger (1979 apud Alves, 2001, p. 54) os neologismos são classificados em:

(a) Formais: criados com base na derivação, composição, formação por sintagmas, siglas, redução de palavras ou ainda na criação de um radical inédito;

(b) Semânticos: são resultados de um novo significado atribuído a um significante já existente;

(c) Por empréstimo: resultantes da adoção de uma unidade lexical estrangeira.

Verifica-se que, por esta classificação, tanto os neologismos da língua geral como os terminológicos são constituídos pelos mesmos processos de formação de palavras, assumindo, desde o momento de sua criação, as características do sistema ou $\mathrm{da}(\mathrm{s})$ norma(s) de que fazem parte $^{18}$.

Os neologismos terminológicos resultam da necessidade de designar novos conceitos vinculados às novas descobertas, teorias, produções das áreas técnicas, científicas ou de outra especialidade. A esta característica Guilbert (1975 apud Correia, 1998, p. 62) chama de função denominativa dos neologismos terminológicos. Cabré (1993 apud Correia, 1998, p. 65), por sua vez, estabelece condições linguísticas para viabilidade de implantação desses neologismos. Assim, o neologismo

(1) deve denominar um conceito estável, delimitado com o qual mantenha relação de univocidade;

(2) deve ser breve e conciso;

(3) deve ser construído de acordo com as regras do próprio sistema linguístico;

(4) deve ser transparente;

(5) deve poder constituir base para série de palavras derivadas;

\footnotetext{
17 Também chamado de neônimo (Rondeau, 1984 apud Alves, 2001, p. 57) ou neotermo (Boulanger, 1989 apud Alves, 2001, p. 57). Contudo, neste trabalho usaremos o termo "neologismo terminológico".

${ }^{18}$ Para um estudo mais pormenorizado a respeito dos processos de formação das unidades neológicas das áreas de especialidade ver Alves (2011, pp. 53-70).
} 
(6) deve adaptar-se ao sistema fonológico e ortográfico da língua.

Correia (1998, p. 67) frisa que tão ou mais importante que criar termos é normalizá-los e divulgá-los entre os utilizadores mais diretos no âmbito da comunicação científica ou técnica.

Uma outra forma de expressar conceitos novos ou inexistentes na língua de chegada está na paráfrase (do termo original), definida como um enunciado descritivo do conteúdo vinculado pelo termo que, no entanto, não substitui a definição terminológica. Loguercio (2001, p. 416) alerta o terminólogo quanto ao uso da mesma e aponta para o perigo de sua inadequação quando esta não se limita ao conceito expresso pelo termo na outra língua. A solução dada ao terminólogo é, ao mesmo tempo, analisar o termo numa perspectiva textual-discursiva, não como mero portador de um conceito isolado, e possuir o conhecimento profundo do domínio em questão, o que auxiliará nas tomadas de decisão mais adequadas.

Considera-se oportuno citar aqui o que Quemada (1971 apud Alves, 2001, p. 67) diz acerca da importância do processo neológico para a evolução das línguas naturais, um assunto controverso entre os profissionais que pregam o purismo linguístico:

[...] uma língua de cultura, moderna, necessariamente científica e técnica, não pode ver na neologia lexical apenas um mal inevitável. É a primeira condição a partir da qual o idioma pode permanecer um instrumento de comunicação nacional, mesmo internacional, e não ser apenas uma língua viva. Deve até considerar a criatividade lexical como parte responsável pela sua riqueza imediata, como sinal evidente de sua vitalidade. Uma língua que não conhecesse nenhuma forma de neologia seria uma língua morta e, em suma, a história de todas as nossas línguas constitui a de sua neologia.

Neste primeiro capítulo, revisaram-se os pressupostos teóricos da Terminologia, Terminografia, Lexicologia e Lexicografia, bem como foram delimitados os objetos de estudo da Terminologia. Em seguida, foram retomadas as definições de três obras de referência - dicionário de língua, dicionário terminológico e glossário, de acordo com a visão de três autoras especializadas, a saber, Maciel (2001), Barbosa (2001) e Barros (2004), acompanhada da justificativa pela escolha da elaboração de um 
glossário dos termos gramaticais estudados. Foi abordada, também, a conceituação dos neologismos terminológicos devido à necessidade de criação de novos termos ao longo da dissertação.

No próximo capítulo, apresentam-se a metodologia de trabalho adotada nesta pesquisa, os corpora investigados, certos aspectos técnicos do glossário e as fichas terminológicas elaboradas para análise dos termos selecionados. 


\section{Capítulo II}

\section{Da Metodologia de Trabalho}

Antes de delinear a metodologia usada neste trabalho, julga-se necessário o esclarecimento de certos aspectos técnicos, a saber, seu objetivo, o público alvo, os limites da pesquisa, a delimitação da nomenclatura e a organização interna do glossário. Posteriormente, serão apresentadas as fichas terminológicas, bem como serão discutidos os critérios de tratamento dos termos.

- Objetivo: esta pesquisa busca padronizar a terminologia morfossintática do verbo árabe por meio da investigação científica, para que, ao final, seja produzido um glossário Árabe-Português/ Português-Árabe que auxilie tanto os profissionais da área - pesquisadores e professores, quanto os estudantes de árabe, os quais recorrerão à obra a fim de "adquirir certos conhecimentos que lhes permitam decodificar textos científicos e avançar em seus estudos" (Barros, 2004, p. 191).

Não foi observada a necessidade, neste momento, da elaboração de um dicionário terminológico, entretanto, o necessário contraste dos semas das definições, para que se chegue a uma padronização em português, será realizado durante o capítulo de análise. Dessa forma, o glossário apenas sistematizará o produto de tal análise, facilitando a consulta e o acesso às informações.

- Público alvo: este trabalho destina-se a priori ao leitor brasileiro que tenha a língua árabe como objeto de estudo ou interesse, sendo possível atender às necessidades dos interessados lusófonos. Poderá ser útil também aos árabes que, por motivos diversos, tenham a língua portuguesa como objeto de estudo e de interesse. Por esse motivo, após a apresentação do glossário principal ÁrabePortuguês, organizou-se sua contraparte Português-Árabe a fim de auxiliar os arabófonos interessados na busca de informações.

- Limites da pesquisa e delimitação da nomenclatura: este trabalho encontra-se no domínio da morfossintaxe do verbo árabe, de onde foram extraídos dez termos principais. Sabe-se que, dentro da teoria gramatical, cada um desses referidos 
termos desdobra-se em subclassificações de onde emergem novos termos correlatos, os quais também serão contemplados neste trabalho terminológico. Assim, farão parte da nomenclatura (ou nominata) final do glossário os dez termos principais somados aos subitens de cada unidade terminológica estudada (sem diferenciar entre entrada principal ou secundária), assim totalizando vinte e seis termos.

- Organização interna: a macroestrutura do glossário Árabe-Português será organizada seguindo a ordem alfabética árabe, no entanto, a metodologia de elaboração da obra será baseada no sistema conceitual, isto quer dizer que, durante a análise, os termos serão tratados de acordo com a ordem em que aparecem no sistema de conceitos ${ }^{19}$.

Cada entrada no glossário Árabe-Português estará posicionada à direita ${ }^{20}$ e será escrita em caracteres árabes, sendo seguida por sua transliteração, e, a sua esquerda, constará a proposta de padronização em português. Portanto, a microestrutura da obra final será constituída apenas pela lista de unidades terminológicas padronizadas em português, segundo a proposta de Barros (2004) para glossário.

As entradas da contraparte Português-Árabe estarão posicionadas à esquerda, segundo a ordem de escrita portuguesa e organizadas alfabeticamente. $\mathrm{Na}$ segunda coluna, virá o termo em árabe correspondente, seguido por sua transliteração.

- A metodologia de trabalho seguirá o percurso abaixo e terá como objetivo final o preenchimento dos campos das fichas terminológicas que serão apresentadas $\operatorname{logo}$ a seguir. Com as fichas devidamente preenchidas, o plano geral do tratamento terminológico de cada termo será evidenciado, o que auxiliará o processo de padronização. Segue, então, o percurso metodológico:

\footnotetext{
${ }^{19}$ De acordo com as teorias terminográficas, esta ordem é chamada de alfassistemática, por mesclar tanto a ordem alfabética (a ordem da macroestrutura) quanto à sistemática (base para a metodologia de trabalho).

${ }^{20}$ A ordem de escrita da língua árabe inicia-se da direita para esquerda, por isso a nomenclatura estará posicionada à margem direita.
} 


\section{(1) Descrição do termo de acordo com a teoria gramatical árabe ${ }^{21}$ :}

Acredita-se que o ponto de partida da investigação seja a própria língua árabe, isto é, como a gramática prescreve os fatos linguísticos para os árabes. Por isso, consideram-se quatro autores árabes modernos, a saber, Alḥawṣ (1987), Alhatīb \& Jațal (1993), Almªrī (2002) e c ${ }^{c} \bar{A} l \bar{i}$ (2006). O objeto de descrição dos mesmos é a língua Árabe Moderna Padrão cuja estrutura e vocabulários são mais simplificados se comparados ao Árabe Clássico.

\section{(2) Apresentação da tradução literal em português:}

A tradução literal dos termos foi pautada nas definições encontradas nos dicionários Wehr (árabe-inglês, 1976), Al-Mawrid ${ }^{22}$ (1995); Corriente (árabe-espanhol, 1991) e Sabbagh (árabe-português, 2011).

Já que a unidade terminológica faz parte do léxico geral da língua, considerar outras acepções possíveis de cada termo, quando não houver uma especificamente linguística, auxiliará o entendimento das opções terminológicas dos gramáticos não árabes selecionados, assim como poderá nortear a padronização em português.

\section{(3) Indicação da escolha terminológica feita pelos arabistas selecionados para o item estudado:}

Neste passo, as opções terminológicas de cada gramático não árabe selecionado serão analisadas e contrastadas, verificando a pertinência temática ${ }^{23}$ e pragmática dos termos adotados.

Foram selecionadas sete gramáticas árabes escritas por arabistas de diferentes nacionalidades e épocas, com o intuito de observar o tratamento dado às terminologias gramaticais. Segue a lista dos arabistas e suas obras, assim como a justificativa por sua escolha:

\footnotetext{
${ }^{21}$ Foi adotado o seguinte critério quanto à escrita e transliteração dos termos árabes: a primeira vez em que os termos forem mencionados, estes serão escritos em caracteres árabes seguidos de sua transliteração. Nas outras vezes em que forem citados, constará apenas sua transliteração.

22 Trata-se do dicionário árabe-inglês, cujo autor é Dr. Rohi Baalbaki. Este foi o nome pelo qual a obra lexicográfica ficou conhecida.

${ }^{23}$ Segundo Maciel (2001a, p. 277) “Os termos, sejam unidades sígnicas ou lexicais, são vinculadas à área temática pelo significado ou pela funcionalidade. No primeiro caso, trata-se de pertinência temática propriamente dita, no segundo, de pertinência pragmática".
} 


\section{a) Instituições da Língua Arabiga para o Uso das Escolas da Congregação da} Terceira Ordem (1774), de Fr. António Baptista Abrantes, primeiro professor da cadeira de árabe no Convento de Nossa Senhora de Jesus, em Lisboa. Para a elaboração desta gramática, Fr. António seguiu o modelo da gramática de Thomas Erpenius, publicada em 1612, a qual permaneceu como guia para estudiosos europeus ao longo de dois séculos. Da mesma forma que Erpenius, Fr. António Baptista preocupou-se em oferecer aos estudantes textos árabes, como base para leitura, recorrendo com maior frequência a textos religiosos devido, principalmente, à dificuldade de acesso a textos de autores árabes. Por isso, ao final de sua descrição, há um salmo de David em árabe como exercício das lições apresentadas. Frei Abrantes foi designado confessor da princesa do Brasil, D. Carlota Joaquina, em 1794, por esse motivo, acompanhou a família real portuguesa na transmigração para o Brasil em 1807. Em pesquisa recente à Biblioteca Nacional, encontrou-se um exemplar impresso da gramática de Abrantes, a qual, provavelmente, era parte integrante da Real Biblioteca transladada para a nova sede do reino português.

b) A Grammar of Arabic Language (1859 e 1862), de William Wright, professor da Universidade de Dublin, importante centro de estudos orientais no século XIX. Sua gramática foi uma das mais destacadas durante décadas, continuando a ser referência até o momento. Segundo o autor, esta gramática veio preencher uma lacuna na literatura filológica inglesa da época. Em seu prefácio, Wright cita autores de renome, como De Sacy e Edwald, cujas obras serviram de base para seu estudo, sem, contudo, se limitar ao produzido por eles. Explicita também que sua gramática apresenta uma abordagem comparativa do árabe com outras línguas semíticas (hebraico, amárico ${ }^{24}$, fenício, aramaico, caldeu e siríaco), uma perspectiva pouco compreendida em seu país naquele momento. Abordaram-se os volumes 1 e 2 de sua gramática. No primeiro volume, o autor trata da ortografia e morfologia árabe, no segundo, da sintaxe e prosódia.

\footnotetext{
${ }^{24}$ Idioma semítico falado na Etiópia.
} 
c) Nouvelle Grammaire Arabe (1911), de Augustin Périer. Professor pósgraduado em árabe, hebraico e etíope, abordou em sua obra os conteúdos gramaticais voltados a alunos iniciantes. Segundo o autor, duas falhas eram constantes nos materiais elaborados por autores contemporâneos: 1) a explicação dos conteúdos era rudimentar, sendo aplicada a textos fáceis, o que resultava em um conhecimento insuficiente para a leitura e compreensão dos grandes prosadores e poetas árabes; 2) emprego desordenado e maciço de termos gramaticais. Périer procurou evitar tais 'falhas' em seu trabalho, assim como propôs exercícios práticos para fixação dos conteúdos gramaticais e extraiu seus exemplos das melhores obras da literatura árabe. É interessante também a metodologia empregada na divisão dos capítulos, pois o autor divide sua gramática em três partes: a primeira é chamada de "leitura" e reservada à iniciação no idioma, reconhecimento de seus fonemas e características primordiais para o prosseguimento do estudo; na segunda parte, estuda-se a morfologia da língua árabe; e, na terceira, sua sintaxe.

d) A New Arabic Grammar of Written Language (1965), de J.A. Haywood e H.M. Nahmad, uma gramática que pretendia modificar o paradigma de estudo do árabe no pós Segunda Guerra, quando a língua árabe ganhou representatividade devido aos movimentos de independência dos países do Oriente Próximo. Esta gramática foi reeditada por diversas vezes, e se destaca, em sua época, por apresentar exemplos tanto do Árabe Clássico como do Árabe Moderno Padrão, indicando quais os usos são obsoletos e quais continuam sendo utilizados. Além disso, há, ao final do livro, uma seleção de textos provenientes de fontes clássicas e da mídia moderna somados a três anexos (A, B e C) que contêm informações sobre os diferentes dialetos árabes, um guia para estudos posteriores e notas gramaticais suplementares, respectivamente. Esta gramática continua sendo, ainda hoje, um referencial para professores e alunos.

e) Gramática Árabe (1992), de F. Corriente, célebre catedrático dos estudos árabes e islâmicos da Universidade Complutense de Madrid. Em sua gramática, Corriente considera tanto a língua clássica em toda sua complexidade, como o vocabulário e características morfossintáticas do Árabe 
Moderno Padrão. Segundo o autor, sua metodologia veio preencher uma lacuna existente na literatura em língua espanhola.

f) A Reference Grammar of Modern Standard Arabic (2005), de Karin Ryding, em que a autora descreve as estruturas do Árabe Moderno Padrão, empregando uma abordagem teórica contemporânea. É interessante também a maneira como a autora lida com as terminologias, pois, sem perder de vista seu leitor, apresenta os termos em árabe e inglês, optando, muitas vezes, pela caracterização árabe de determinado fenômeno devido a seu pragmatismo. Ao fim de sua gramática, Ryding disponibiliza um glossário árabe-inglês dos termos gramaticais árabes.

g) Gramática do árabe moderno: uma introdução (2007), de David Cowan, a primeira gramática sistemática do árabe traduzida e adaptada para o português do Brasil. Originalmente escrita em língua inglesa, a gramática de Cowan foi editada pela primeira vez em 1958 e reimpressa em média a cada dois anos. Possui metodologia simples e clara, com exercícios de fixação ao fim de cada capítulo, porém, a motivação da escolha da obra para este trabalho é o fato de ser uma tradução para o português, em que a questão terminológica foi pensada por duas vezes, seja pelo autor, Cowan, seja pela tradutora, Jubran (2006).

Foram utilizados, também, como fonte de pesquisa três obras de referência sobre terminologia gramatical árabe, uma árabe-francês Vocabulaire des Principaux Terms Techniques de la Grammaire Arabe (Machuel, 1908), e duas árabe-inglês A Dictionary of Arabic Grammatical Terms (Cachia, 1973) e A Dictionary of Modern Linguistic Terms (Bakalla et al., 1983). Observa-se que tais obras possuem estrutura de glossário assim como definida por Barros (2004, p. 144) e adotada nesta pesquisa, isto é, dicionário bilíngue que apresenta somente uma lista de unidades terminológicas acompanhadas de seus equivalentes em outras línguas. 


\section{(4) Verificação de possíveis correspondências gramaticais entre o árabe e o português do Brasil.}

Quanto às correspondências gramaticais entre a língua de partida - o árabe, e a língua de chegada - o português, acredita-se que três situações diferentes se revelarão: (a) possível correspondência direta, relação biunívoca; (b) correspondência indireta, isto é, um termo árabe com dois ou mais referentes na gramática portuguesa; (c) ausência de correspondente em português. Quando tal correspondência não for evidenciada, outros aspectos da gramática portuguesa serão investigados, a fim de se encontrar uma terminologia mais adequada.

Caso se verifique a ausência da biunivocidade entre a terminologia verbal árabe e a portuguesa, haverá a necessidade de criação neológica. Os neologismos terminológicos serão do tipo formais ou por empréstimos, segundo a classificação de Boulanger, apresentada no item 6, do capítulo anterior. Os neologismos por empréstimos serão grafados entre aspas, a fim de sinalizar o estatuto neológico.

A investigação na gramática portuguesa, bem como as definições terminológicas dos possíveis fatos gramaticais portugueses correspondentes aos árabes serão extraídas do seguinte corpus:
a) Gramática do Português Brasileiro - Castilho (2010)
b) Gramática Houaiss da Língua Portuguesa - Azeredo (2010)
c) Gramática Descritiva do Português - Perini (2003)
d) Gramática Normativa da Língua Portuguesa - Rocha Lima (2002)
e) Moderna Gramática Portuguesa - Bechara (1999)
f) Dicionário de Linguística e Gramática - Mattoso Câmara (1981)

Faz-se importante esclarecer que os comentários gramaticais desenvolvidos antes de alguns dos termos estudados não buscam o aprofundamento exaustivo de tais categorias ou processos linguísticos, visam antes ao contraponto da realidade em ambas as línguas, fornecendo um pano de fundo para a posterior análise e discussão terminológica cujo objetivo é a padronização em língua portuguesa. 
Para cada situação acima descrita, no item (4), um tipo de ficha terminológica foi elaborado, a fim de dar conta do termo pesquisado. Assim, para a primeira situação, segue a Ficha Terminológica 1:

\begin{tabular}{|c|c|c|c|c|}
\hline \multicolumn{2}{|r|}{ Termo } & $\begin{array}{c}\text { Possível correspondência } \\
\text { em Pt }\end{array}$ & \multicolumn{2}{|c|}{ Proposta de padronização } \\
\hline DT: & & DT & TL: & \\
\hline Ex.: & & Ex.: & Fonte: & \\
\hline Fonte: & & Fonte: & & \\
\hline $\mathbf{P t}_{1774}$ & & $\mathbf{E s}_{1992}$ & $\operatorname{Voc}_{1908}$ & \\
\hline $\mathbf{P t}_{2007}$ & & $\mathbf{F r}_{1911}$ & Dic $_{1973}$ & \\
\hline $\operatorname{In}_{1859}$ & & $\operatorname{In}_{1965}$ & Dic $_{1983}$ & \\
\hline $\operatorname{In}_{2005}$ & & & & \\
\hline
\end{tabular}

Para a segunda situação, segue a Ficha Terminológica 2:

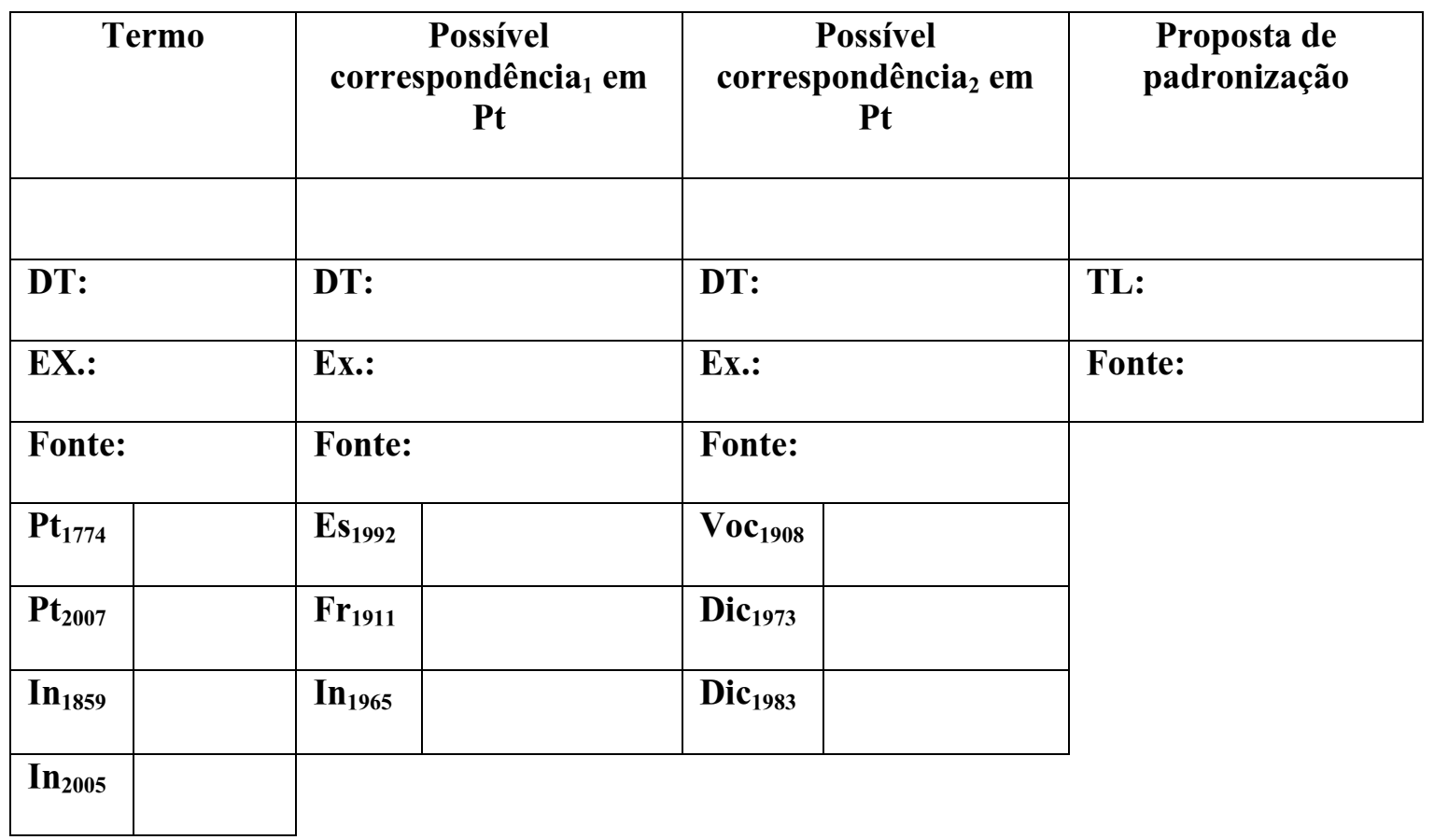


Para a terceira situação, segue a Ficha Terminológica:

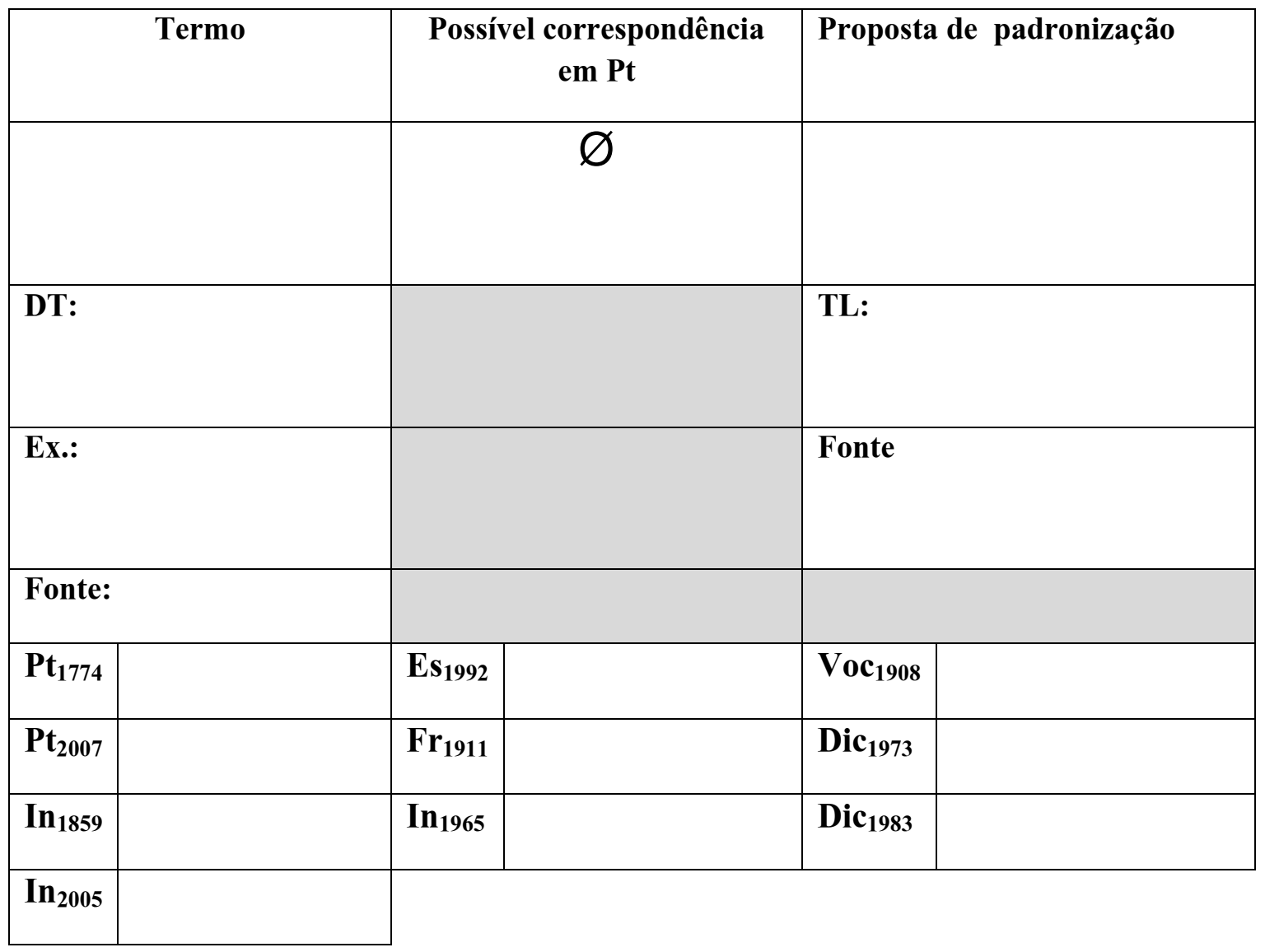

As fichas acima foram elaboradas em função das necessidades e dos objetivos do presente trabalho. Elas sintetizarão os dados mais relevantes para uma padronização pertinente e funcional dos termos árabes em português. A tabela seguinte explica cada campo das fichas terminológicas: 


\begin{tabular}{|c|c|}
\hline Campos & Explicação \\
\hline Termo & Termo escrito em árabe e transliterado \\
\hline DT & Definição terminológica \\
\hline Fonte & $\begin{array}{c}\text { Fonte da definição terminológica e da } \\
\text { tradução literal }\end{array}$ \\
\hline Ex. & $\begin{array}{l}\text { Exemplo do termo ou do correspondente em } \\
\text { português }\end{array}$ \\
\hline TL & Tradução literal \\
\hline Possível correspondente em Pt & $\begin{array}{c}\text { Possibilidade de correspondência gramatical } \\
\text { em português }\end{array}$ \\
\hline$\varnothing$ & Ausência de correspondente em português \\
\hline $\mathbf{P t}_{1774}$ & Gramática do Frei Abrantes (1774) \\
\hline $\mathbf{P t}_{2007}$ & Gramática do Cowan (2007) \\
\hline $\mathbf{E s}_{1992}$ & Gramática do Corriente (1992) \\
\hline $\mathrm{Fr}_{1911}$ & Gramática de Périer (1911) \\
\hline $\operatorname{In}_{1859}$ & Gramática do Wright, vol. 1 (1859) \\
\hline $\operatorname{In}_{1862}$ & Gramática do Wright, vol. 2 (1862) \\
\hline $\operatorname{In}_{1965}$ & Gramática do Haywood \& Nahmad (1965) \\
\hline $\mathbf{I n}_{2005}$ & Gramática da Ryding (2005) \\
\hline Voc $_{1908}$ & $\begin{array}{c}\text { Vocabulaire des Principaux Terms Techniques } \\
\text { de la Grammaire Arabe (1908) }\end{array}$ \\
\hline Dic $_{1973}$ & $\begin{array}{l}\text { A Dictionary of Arabic Grammatical Terms } \\
\qquad(1973)\end{array}$ \\
\hline Dic $_{1983}$ & $\begin{array}{l}\text { A Dictionary of Modern Linguistic Terms } \\
\qquad(1983)\end{array}$ \\
\hline
\end{tabular}

Tabela 2 Campos das fichas terminológicas

Após o esclarecimento do percurso metodológico adotado nesta pesquisa, passa-se à apresentação dos termos árabes selecionados e sua efetiva investigação segundo os critérios acima delineados. 


\section{Capítulo III}

\section{Análise e Discussão dos Termos}

Trabalhem, trabalhem, trabalhem. Doutor Alphonse Nagib Sabbagh ${ }^{25}$

Este capítulo destina-se à análise e discussão dos termos árabes em estudo. A investigação será encabeçada pelos termos principais enumerados de 1 a 10, conforme a tabela 3 abaixo:

\begin{tabular}{|c|c|c|c|}
\hline & Tradução literal $^{26}$ & Transliteração & Termos árabes \\
\hline 1 & "o verbo forte e fraco" & alficl aș-șaḥihh wa almuctal & الفِعْل الصَّحيح والمُعْتَّل \\
\hline 2 & "o verbo passado" & alficl almāọ̄ & الفِعْلَ الماضي \\
\hline 3 & "o verbo semelhante" & alficl almuḍāic $^{c}$ & الفِعْل المُضارِع \\
\hline 4 & "o verbo da ordem" & ficl al'amr & فِعْل الأمَز \\
\hline 5 & $\begin{array}{c}\text { "o verbo necessário e o } \\
\text { excedente" }\end{array}$ & $\begin{array}{l}\text { alficl al-lāzim wa } \\
\text { almutacad }^{c}\end{array}$ & الفِعْل اللازِمِ والمَتَْْدَي \\
\hline 6 & $\begin{array}{c}\text { "o verbo construído para o } \\
\text { conhecido e para o } \\
\text { ignorado" }\end{array}$ & $\begin{array}{l}\text { alficl almabnì li-almaclūm } \\
\text { wa li-almajhūl }\end{array}$ & اللَفِلْ المَبْنِي للمَعْلوم \\
\hline 7 & "os verbos defectivos" & al'af'āl an-nāqiṣa & الأَفْعال الناقِصة \\
\hline 8 & $\begin{array}{l}\text { "o verbo nu e o } \\
\text { aumentado" }\end{array}$ & $\begin{array}{l}\text { alficl almujarrad wa } \\
\text { almazìd }\end{array}$ & الفعل المُجَرَّد والمَزيد \\
\hline 9 & $\begin{array}{l}\text { "verbos de aproximação, } \\
\text { de desejo e de iniciação" }\end{array}$ & $\begin{array}{l}\text { 'afcāl almuqāriba wa ar- } \\
\text { rajā' wa aš-šurüc }\end{array}$ & 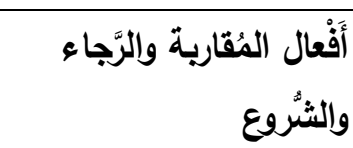 \\
\hline 10 & $\begin{array}{l}\text { "verbos de louvor e de } \\
\text { depreciação" }\end{array}$ & $\begin{array}{l}\text { 'af'āl almadh wa ad- } \\
\text { damm }\end{array}$ & أَفْعال المَدَح والذَّمّ \\
\hline
\end{tabular}

Tabela 3. Termos investigados

\footnotetext{
${ }^{25}$ Trecho do discurso do Monsenhor Alphonse Nagib Sabbagh em ocasião do I Simpósio de Arabistas Luso-Brasileiros (Vargens \& Caffaro (org.), 2010, p.22).

${ }^{26}$ A tradução literal será abordada em cada ficha terminológica. Sua inserção, nesta tabela, tem por objetivo auxiliar o leitor não especializado na compreensão prévia de cada termo.
} 
Como cada termo deste representa um fato gramatical, outros correlatos emergirão os quais serão submetidos ao mesmo processo de análise adotado, a fim de compor o glossário final.

Antes, porém, de iniciar a análise dos termos propostos, julga-se importante posicionar a presente pesquisa dentro da teoria gramatical árabe, que classifica os itens lexicais da língua em três categorias: o nome (إسنْ 'ism), a partícula (حَرْ harf) e o verbo $\left({ }^{2} f^{c} l\right)^{27}$ - sendo este último o foco do trabalho.

O "nome" - compreende as classes de substantivo, adjetivo, numeral e pronome portugueses.

A "partícula" - refere-se ao artigo, à preposição, à conjunção, ao advérbio e à interjeição portuguesa.

O "verbo" - equivale ao verbo, tanto em português quanto nas línguas de chegada estudadas, a saber, o espanhol, o francês e o inglês.

No intuito de observar se a correspondência terminológica é realmente direta, apresentam-se as definições do termo verbo em ambas as línguas para o contraste dos semas que constituem o semema ${ }^{28}$ das DT.

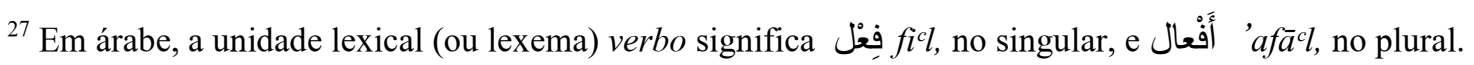
28 "Definindo semema como um conjunto de semas, podemos afirmar que a cada lexema deve corresponder no mínimo um semema, ou seja, uma acepção aceita culturalmente, no âmbito da língua em apreço." (Pietroforte \& Lopes, 2003, p. 119)
} 


\begin{tabular}{|c|c|c|c|c|c|}
\hline & Termo & Pos: & $\begin{array}{l}\text { el correspondência } \\
\text { em Pt }\end{array}$ & Propo & a de padronização \\
\hline & فِ فِعْل & & Verbo & & Verbo \\
\hline $\begin{array}{l}\text { DT: } \\
\text { "O qu } \\
\text { um ac } \\
\text { um ten }\end{array}$ & $\begin{array}{l}\text { indica o significado de } \\
\text { ntecimento associado a } \\
\text { po }^{29} \text {." }\end{array}$ & $\begin{array}{l}\text { DT: } \\
\text { "O ve } \\
\text { um a } \\
\text { passa } \\
\text { torno } \\
\text { oraçã } \\
\text { de } \\
\text { grama } \\
\text { grama } \\
\text { mude } \\
\text { cinco } \\
\text { númer }\end{array}$ & $\begin{array}{l}\text { o expressa um fato, } \\
\text { ntecimento: o que se } \\
\text { om os seres, ou em } \\
\text { s seres. É a parte da } \\
\text { nais rica em variações } \\
\text { ma ou acidentes } \\
\text { cais. Estes acidentes } \\
\text { cais fazem que ele } \\
\text { forma para exprimir } \\
\text { deias: modo, tempo, } \\
\text { pessoa e voz." }\end{array}$ & $\begin{array}{l}\text { TL: } \\
\text { 1. Açã } \\
\text { Verbo. } \\
\text { 2. Acc } \\
\text { Verbo. }\end{array}$ & $\begin{array}{l}\text { ato, fato, efeito. } \\
\text { n, acto. Función. }\end{array}$ \\
\hline $\begin{array}{l}\text { Ex.: } \\
\text { kataba } \\
\text { qara'a } \\
\text { 'ahabb }\end{array}$ & & $\begin{array}{l}\text { Ex.: } \\
\text { Canta }\end{array}$ & beber, partir & $\begin{array}{l}\text { Fonte: } \\
\text { 1. Sabb } \\
\text { 2. Corr }\end{array}$ & $\begin{array}{l}\text { h, 2010, p. } 516 \\
\text { te, } 1991, \text { p. } 591\end{array}$ \\
\hline $\begin{array}{l}\text { Fonte: } \\
\text { Alhaw }\end{array}$ & 1987, p. 16 & $\begin{array}{l}\text { Fonte } \\
\text { Lima, }\end{array}$ & 02, p. 122. & & \\
\hline $\mathbf{P t}_{1774}$ & Verbo & $\mathbf{E s}_{1992}$ & Verbo & Voc $_{1908}$ & Action, acte. Verbe \\
\hline $\mathbf{P t}_{2007}$ & Verbo & $\mathrm{Fr}_{1911}$ & Verbe & Dic $_{1983}$ & Verb \\
\hline $\mathbf{I n}_{1859}$ & Verb & $\mathbf{I n}_{1965}$ & Verb & $\mathbf{I n}_{2005}$ & Verb \\
\hline
\end{tabular}

Apesar de a definição terminológica do termo em português ser bem mais densa do que a DT árabe, ambas expressam ideias convergentes. Os semas concordantes são: a. indicar um acontecimento, uma ação e b. ação associada a um tempo.

As informações registradas na ficha terminológica demonstram que há consenso quanto à padronização do termo $\mathrm{fi}^{c} \mathrm{l}$ na língua de chegada dos autores estudados. É possível que a escolha pela padronização tenha sido proveniente também

\footnotetext{
${ }^{29}$ Tradução nossa de: "ما يَلَّ على معنى حدوث عمل في نفسه، مقترنٍ بالزمن"(mä yadullu calà macnà hudūtin ${ }^{c}$ amalin fì nafsihi, muqtarinin biz-zaman.)
} 
da tradução do termo, cuja raiz $f_{-}{ }^{-}-l$ abarca o sentido de "execução", "ação" e, por extensão de sentido, tenha originado o termo verbo.

Esta raiz foi (e ainda é) usada para indicar todos os paradigmas nominais e verbais previstos na língua árabe. Cowan (2007, p. 33) acrescenta que:

Quando os árabes começaram a ensinar sua língua, depois da expansão islâmica no século VII, adotaram a palavra mais simples da sua língua فَعَ facala, ele fez, e utilizaram suas três letras radicais ف

$\mid f$, ع/c, J/l, com total independência de toda a ideia de "fazer", para descrever os diferentes modelos de palavras que eles constataram como existentes.

É interessante notar que embora não haja interdependência entre o conteúdo da raiz $f_{-} c_{-} l$ e os paradigmas tanto nominais quanto verbais que ela representa, observa-se estreita conexão entre o termo $f i^{c}$ e o fenômeno que ele designa, isto é, ser o verbo da oração.

Assim, a DT árabe embora concisa ajusta-se perfeitamente à DT portuguesa, por isso, verifica-se que a correspondência entre os termos $f i^{c} l$ e verbo é, de fato, direta.

\section{1. alficl aṣ-ṣaḥihh wa almuctal}

O sintagma terminológico الفِعْل الصَّحيح والمُعْنَّل alficl aṣ-ṣahīh wa almuctal refere-se à tipologia das raízes verbais ${ }^{30}$ árabes, que podem ser triconsonantais ${ }^{31}(d-r-s$, raiz de "estudar") ou quadriconsonatais ( $t-r-j-m$, raiz de "traduzir").

De acordo com a formação fonêmica das raízes, os verbos são classificados entre صَحِ șiḥh - aqueles que, entre suas consoantes formadoras, não há a presença

\footnotetext{
${ }^{30}$ Schramm (1962, p. 360) afirma que o radical verbal árabe é um complexo de dois morfemas descontínuos e interligados, uma raiz consonantal, com a informação lexical, e um padrão vocálico, com o conteúdo da voz (passiva vs. não passiva).

${ }^{31} \mathrm{O}$ presente estudo priorizará os verbos triconsonantais por serem a maioria na língua árabe. Os verbos quadriconsonantais são, contudo, menos frequentes.
} 
de semiconsoantes ${ }^{32}$; e مُعْres $m u^{c} t a l$ - aqueles verbos que, entre suas letras consonantais - os chamados radicais, verifica-se, ao menos, uma das duas semiconsoantes da língua árabe: $و w \bar{a} w$ e $y \bar{a}$.

De acordo com a classificação proposta pelos gramáticos árabes, o verbo șaḥịh pode ser de três tipos:

(1) Sālim ("forte") : verbos cuja raiz não possui nem a consoante hamza ${ }^{34}$ nem consoantes duplicadas. A característica deste grupo é que sua raiz se adapta a qualquer paradigma flexional a que for submetido, sem incorrer em alterações morfológicas. $\mathrm{O}$ paradigma triconsonantal é $\mathrm{C}_{\mathrm{v}} \mathrm{C}_{\mathrm{v}} \mathrm{C}_{\mathrm{v}}$. Exemplo: kataba (escrever), jalasa (sentar-se);

(2) Sُضَعََّّف $m u d a^{c c} a f$ (“dobrado"): verbos cuja segunda e terceira consoantes radicais são idênticas. Em seu paradigma, ocorre uma duplicação na segunda consoante e alteração do padrão vocálico, podendo ser ilustrado desta forma: $\mathrm{C}_{\mathrm{v}} \mathrm{C}_{\varnothing} \mathrm{C}_{\mathrm{v}}>\mathrm{C}_{\mathrm{v}} \mathbf{C C}_{\mathrm{v}}$. Em árabe, a duplicação é marcada por um diacrítico (o šadda _ ${ }^{-}$) colocado sobre a consoante radical duplicada. Exemplo: marra (passar por), tamma (completar-se); كَهْموز mahmūz ("golpeado"): verbos que possuem a consoante hamza como constituinte da raiz, podendo ser a primeira, a segunda ou a terceira

\footnotetext{
${ }^{32}$ Observou-se que não há padronização terminológica entre os gramáticos não árabes estudados quando se referem aos elementos $[\mathrm{w}]$ e $[\mathrm{y}]$, caracterizados por suas qualidades vocálicas e distribuição consonantal. Ambos são chamados na tradição gramatical árabe de أَحْرُف العِلّة 'ahruf ak illa (literalmente "letras fracas"), contudo, Ryding (2005, p. 431) chama-os de semi-consonant, Cowan (2007, p. 127) denomina-os de letras fracas, Haywood \& Nahmad (1965, p. 215) empregam tanto o termo semi-vowel quanto semi-consonant para indicá-los, Abrantes $(1774$, p. 24) chama-os de letras débeis e quiescentes. Assim, para fins desta dissertação, propõe-se o termo semiconsoante para expressar o [w] e [y] quando formadores da raiz consonantal, seguindo a definição de Mattoso Câmara (1981, p. 216), em que prevê a consonantização de ambos os elementos, em contraste com sua natureza vocálica (embora assilábica) nos ditongos crescentes.

${ }^{33}$ A tradução literal de cada um dos termos acima explicados será abordada quando de sua análise individual.

${ }^{34} \mathrm{O}$ hamza é uma consoante árabe, pronunciada como uma oclusão glotal, fonologicamente representada / $\mathrm{Y} /$, e, de acordo com a transliteração adotada, será simbolizada assim /\%.

${ }^{35}$ Observa-se regularidade no paradigma flexional dos verbos chamados de mahmūz, as mudanças que ocorrem são nas letras que sustentam o hamza. Há regras ortográficas previstas para a escrita desta consoante.
} 
consoante radical. Exemplo: 'amara (ordenar), sa'ala (perguntar), qara'a (ler).

O termo sés $m u^{c} t a l$ se refere aos verbos que contam com o wāw e/ou $y \bar{a}$, como uma de suas três consoantes radicais. Estes verbos possuem uma particularidade em relação ao primeiro grupo: a semiconsoante está sujeita à elisão ou à alteração morfológica quando é formadora de raiz, devido a seu caráter instável e fraco.

De acordo com a gramática árabe, os verbos $m u^{c} t a l$ se subdividem em cinco a partir da posição das semiconsoantes e de sua quantidade na raiz. São eles:

(1) مِنال mitâal ("modelo"): verbos iniciados pelo wāw ou yā'. Exemplo: yabisa (secar) e wajada (encontrar);

(2) أَجَوَف 'ajwaf (“oco”): verbos cuja segunda radical é uma semiconsoante. De

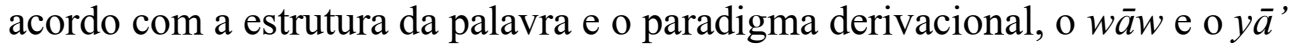
modificam-se em I 'alif, vogal breve, vogal longa ou hamza (Ryding, 2005, p. 461). Exemplo: qā la (dizer), șāra (tornar-se);

(3) ناقِصِ nāqiṣ (“defectivo"): verbos cuja consoante final é um wāw ou um $y \bar{a}$ '. Raízes em que o $w \bar{a} w$ é a consoante final, serão escritas com l 'alif țawīl ${ }^{36}$, e aquelas em que o $y \bar{a}$ ' for a consoante final, serão escritas ou com o próprio $y \bar{a}$ ' ou com o $\mathrm{s}$ 'alif maqșūra ${ }^{37}$. Exemplo: dacia (convidar), radiya (consentir), ramà (lançar).

(4) lafif maqrūn (“misturado ligado"): verbos formados por duas semiconsoantes subsequentes. Exemplo: rawà (narrar) e hayā (viver).

(5) lafíf mafrūq ("misturado intercalado"): verbos formados por duas semiconsoantes intercaladas por uma consoante. Exemplo: wafà (honrar, cumprir uma promessa), waliya (estar a mando de)

Após a delimitação dos termos segundo os pressupostos da gramática árabe, passa-se a análise individual de cada um deles. Serão discutidos dez termos ao total, dois principais e oito subclassificações.

\footnotetext{
${ }^{36} \mathrm{O}$ termo que em árabe significa “ 'alif longo" faz alusão a sua forma e serve para diferenciá-lo do 'alif maqșūra.

$37 \mathrm{O}$ ى'alif maqșūra indica que, devido à ambiência vocálica do paradigma verbal, o $y \bar{a}$ ' sofre alteração em alguns de seus traços característicos, passando de anterior a central, e de alta para baixa.
} 


\section{$1.1 \quad$ sَahịh}

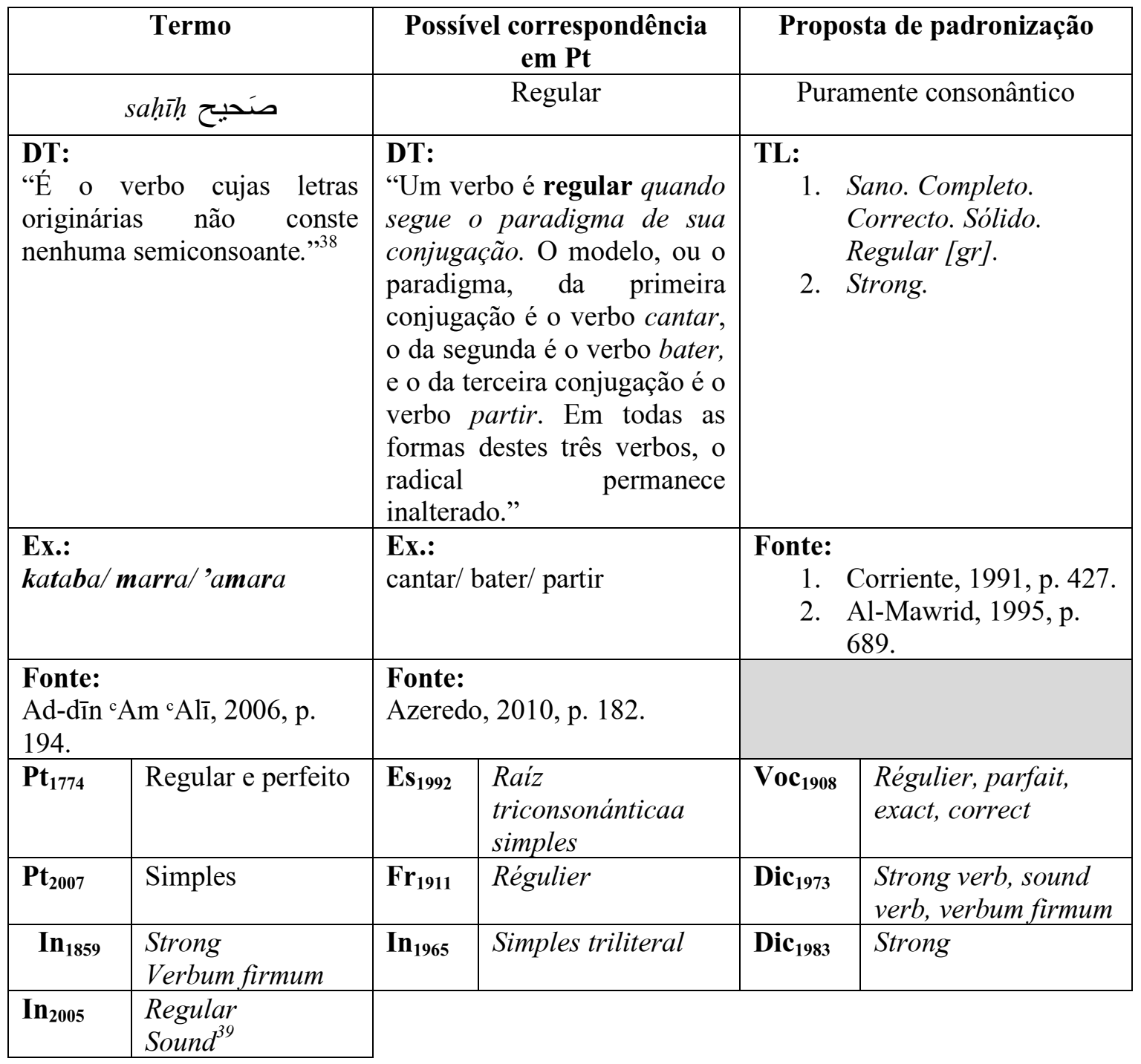

A definição terminológica árabe determina que os verbos șaḥih são aqueles que não possuem em sua constituição as semiconsoantes ${ }^{40}$, letras morfologicamente instáveis formadoras de nomes e verbos.

Wright (1859, p. 48), gramático inglês, define os mesmos verbos como sendo os formados apenas por consoantes radicais fortes, as quais na teoria gramatical árabe

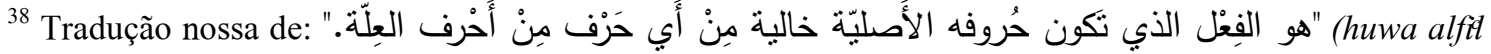
alld̄i takunu hurufuhu al'aṣliya hāliya min 'ay harfin min 'ahrufi ak illa.)

${ }^{39}$ Isto é "são, sadio, saudável".

${ }^{40}$ As semiconsoantes que correspondem ao g $w \bar{a} w$ e $\quad y \bar{a}$ ' são letras cuja natureza é fraca e maleável. Quando estas constituem a raiz de verbos ou nomes, são suscetíveis a alterações na medida em que se conjugam e declinam, respectivamente.
} 
são designadas pelo termo ُروف صحيحة hurūf șaḥịha (El-Daḥdaḥ, 1997, p. 134) e referem-se às vinte e seis consoantes do alfabeto ${ }^{41}$, com exceção das vogais longas - 'alif ${ }^{42}, w \bar{a} w$ e $y \bar{a}$ '.

A característica preponderante das consoantes radicais "fortes" é não sofrer alteração morfológica quando o verbo que elas constituem é flexionado. $\mathrm{Na}$ tabela 4 , o verbo sentar-se - جَلَسَ jalasa - é conjugado. Note como suas consoantes radicais em negrito permanecem inalteradas:

Sentido da leitura

\begin{tabular}{|c|c|c|c|c|}
\hline "Imperativo"43 & "Futuro" & $\begin{array}{l}\text { "Presente do } \\
\text { indicativo" }\end{array}$ & $\begin{array}{l}\text { "Pretérito } \\
\text { Perfeito" }\end{array}$ & $\begin{array}{l}\text { Pessoas do } \\
\text { discurso }\end{array}$ \\
\hline- & $\begin{array}{c}\text { (sentarei) } \\
\text { (سَأَجلِْسُ sa'ajlisu }\end{array}$ & $\begin{array}{c}\text { (sento) } \\
\text { أَجْلِسُ 'ajlisu }\end{array}$ & $\underbrace{\text { جَلَسْنُ jalastu }}_{\text {(sentei) }}$ & أنَا 'anā (eu) \\
\hline & $\begin{array}{c}\text { (sentará) } \\
\text { سَيَجْلِسُ sayajlisu }\end{array}$ & $\begin{array}{c}\text { (senta) } \\
\text { يَجْلِسُ yajlisu }\end{array}$ & $\begin{array}{c}\text { (sentou) } \\
\text { جَلَسَ jalasa }\end{array}$ & hwa (ele) \\
\hline & $\begin{array}{c}\text { سَيَجلِسونَ } \\
\text { sayajlisūna } \\
\text { (sentarão) }\end{array}$ & $\begin{array}{c}\text { يَجْلِسونَ } \\
\text { yajlisūna } \\
\text { (sentam) }\end{array}$ & $\begin{array}{c}\text { جَلَسُوا } \\
\text { jalasu }(\text { sentaram) }\end{array}$ & hُ هُن \\
\hline
\end{tabular}

Tabela 4. Conjugação do verbo جَلَ jalasa

A raiz trilítera $\boldsymbol{j} \boldsymbol{l} \boldsymbol{s}$ manteve-se intacta em todas as conjugações a que foi submetida, alterando-se apenas o padrão vocálico e a afixação inerente a cada paradigma flexional. O comportamento da raiz foi, portanto, regular.

\footnotetext{
${ }^{41}$ A saber \& hamza,

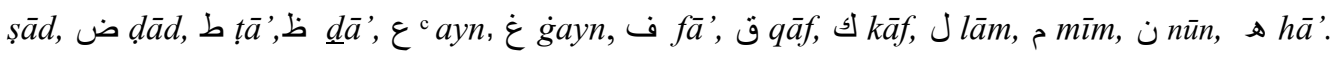

${ }^{42} \mathrm{O} I$ 'alif, forma junto com o $w \bar{a} w$ e o $y \bar{a}$,' o grupo das vogais longas, também referido na teoria árabe pelo termo 'ahruf akilla.

${ }^{43}$ Os termos que indicam as noções de tempo, aspecto e modo estão entre aspas, pois serão discutidos em momento oportuno.
} 
Observa-se que há correspondência entre os seguintes semas das definições árabe e portuguesa, a primeira proposta pelo gramático Wright $(1859$, p. 48), na qual afirma que "[...] as letras radicais [...] não sofrem qualquer mudança [...]" e a segunda, de Azeredo (2010, p. 182), que diz que "[...] o radical permanece inalterado". Tal correspondência justificaria, em parte, a escolha feita por alguns dos autores citados pelo termo "regular" a fim de indicar o verbo șaḥhh, entretanto, constata-se que a regularidade das raízes nos paradigmas flexionais é o resultado da ausência das semiconsoantes entre as consoantes formadoras dos verbos, e não seu princípio motivador.

Quatro acepções foram recorrentes entre os autores listados na ficha terminológica, são elas: "regular", "perfeito", "forte", "simples" e "são". As três primeiras remetem à regularidade flexional destes verbos, como descrita acima, no entanto, acredita-se que a acepção "são", sinônima de "saudável, sadio", tenha sido proposta em oposição a "enfermo"/“fraco", tradução possível da raiz $c-l$ - $l$ (“enfermidade"; “falta”; “fraqueza”), de onde derivam-se o vocábulo أَحْرُف العِلّة ak illa (letras enfermas ou fracas) e o verbo مُعْنَّ $\boldsymbol{m} \boldsymbol{u}^{c} \boldsymbol{t a l}$ (enfermo, fraco). O traço de "enfermidade"/“fraqueza" nestes elementos provém justamente da presença das semiconsoantes $w \bar{a} w$ e $y \bar{a}$ '.

Vê-se que este é o caráter primordial quando se trata da classificação tipológica das raízes verbais. Por esse motivo, sugere-se que o termo șahīh seja designado, em português, pelo sintagma terminológico puramente consonântico, isto é, aquele verbo constituído unicamente por "consoantes fortes", sem contar com nenhuma das semiconsoantes árabes em sua formação.

Dessa forma, acredita-se que a terminologia proposta seja aparente aos leitores mais especializados, aos estudantes de árabe e àqueles mais leigos, refletindo de imediato a característica principal deste grupo de verbos. 


\subsection{1 sālim}

\begin{tabular}{|c|c|c|c|c|c|}
\hline & Termo & \multicolumn{2}{|c|}{$\begin{array}{c}\text { Possível correspondência } \\
\text { em Pt }\end{array}$} & \multicolumn{2}{|c|}{ Proposta de padronização } \\
\hline \multicolumn{2}{|r|}{ sālim سالمِ } & \multicolumn{2}{|c|}{ Regular } & \multicolumn{2}{|c|}{ Triconsonântico simples } \\
\hline \multicolumn{2}{|c|}{$\begin{array}{l}\text { DT: } \\
\text { "Se o verbo for desprovido } \\
\text { de qualquer uma das } \\
\text { semiconsontes (...) e também } \\
\text { de hamza ou duplicação, } \\
\text { então, será chamado de alfì } \\
\text { aș-șah̆h̆ as-sālim. ."44 }\end{array}$} & \multicolumn{2}{|c|}{$\begin{array}{l}\text { DT: } \\
\text { "Um verbo é regular quando } \\
\text { segue o paradigma de sua } \\
\text { conjugação. O modelo, ou o } \\
\text { paradigma, da primeira } \\
\text { conjugação é o verbo cantar, } \\
\text { o da segunda é o verbo bater, } \\
\text { e o da terceira conjugação é o } \\
\text { verbo partir. Em todas as } \\
\text { formas destes três verbos, o } \\
\text { radical permanece } \\
\text { inalterado." }\end{array}$} & \multicolumn{2}{|c|}{$\begin{array}{l}\text { TL: } \\
\begin{array}{ll}\text { 1. } & \text { Regular [verb]. } \\
\text { 2. } & \text { Regular, sano }[\mathrm{gr}] .\end{array}\end{array}$} \\
\hline \multicolumn{2}{|c|}{$\begin{array}{l}\text { Ex.: } \\
\text { kataba/darasa/jalasa }\end{array}$} & \multicolumn{2}{|c|}{$\begin{array}{l}\text { Ex.: } \\
\text { cantar/ bater/ partir }\end{array}$} & \multicolumn{2}{|c|}{$\begin{array}{l}\text { Fonte: } \\
\text { 1. Wehr, 1976, p. } 444 . \\
\text { 2. Corriente, 1991, p. } 370 .\end{array}$} \\
\hline \multicolumn{2}{|c|}{$\begin{array}{l}\text { Fonte: } \\
\text { Alme arī, 2002, vol. 1, p. } 11 .\end{array}$} & \multicolumn{2}{|c|}{$\begin{array}{l}\text { Fonte: } \\
\text { Azeredo, 2010, p. } 182 .\end{array}$} & \multirow[b]{2}{*}{ Voc $_{1908}$} & \multirow[b]{2}{*}{$\begin{array}{l}\text { Sain, régulier, qui ne } \\
\text { renferm pas de } \\
\text { lettres faible (racine) }\end{array}$} \\
\hline $\mathbf{P t}_{1774}$ & Regular e perfeito & $\mathbf{E s}_{1992}$ & \begin{tabular}{|l|} 
Raíz \\
triconsonántica \\
simples
\end{tabular} & & \\
\hline $\mathbf{P t}_{2007}$ & Simples & $\mathbf{F r}_{1911}$ & Régulier & Dic $_{1973}$ & $\begin{array}{l}\text { Strong verb, soun } \\
\text { verb, verbum } \\
\text { infirmum }\end{array}$ \\
\hline In $_{1859}$ & Strong & $\mathbf{I n}_{1965}$ & Simples triliteral & Dic $_{1983}$ & Strong \\
\hline $\mathbf{I n}_{2005}$ & Regular or sound & \\
\hline
\end{tabular}

O verbo سالِم sālim é a primeira subclassificação dos verbos șahīh. Segundo a

DT árabe é aquele que: a. não possui semiconsoantes entre suas radicais; b. não possui hamza; c. não possui consoantes duplicadas.

Observa-se grande semelhança entre as fichas terminológicas do termo șaḥịh e do termo sālim, principalmente no que diz respeito à terminologia adotada pelos gramáticos não árabes, cujas opções variam entre "regular", "perfeito", "forte", "são" e

\footnotetext{
${ }^{44}$ Tradução nossa de: ". يُسَمَّى الفعل الصَّحيح السالِِ ('iḍa kāna alfit hāliyan min harfin min hurūfi alilla ('alif, wāw, yā') wāw hālyian min hamza 'aw šadda yusammà alfit aș-șaḥ̆h as-sālim.)
} 
"simples". A justificativa para este fato está nos critérios utilizados e a classificação proposta por cada autor.

Abrantes (1774, p.121) divide os verbos árabes em regulares e perfeitos e irregulares e imperfeitos. Por regulares e perfeitos, ele entende serem os verbos șahīh do tipo sālim, reunindo ambos os termos em um único grupo.

Wright (1859, p.47) segmenta os verbos em strong verbs ("verbos fortes") e weak verbs ("verbos fracos"). Os primeiros correspondem aos verbos șahīh do tipo sālim e do tipo sُضَعَّف $m u d a^{c c} a f$. O segundo grupo engloba os outros tipos apresentados.

Périer (1911, p. 16) chama os verbos de régulier e irrégulier. Para ele, os verbos regulares são apenas os șahīh do tipo sālim. Todas as outras subdivisões são consideradas irregulares por este autor.

Haywood \& Nahmad (1965, p. 191) inserem dentro do termo simple triliteral verb ("verbo trilítero simples") apenas o șaḥhh do tipo sālim, a todos os outros ele chamará de irregulares, embora afirmem que este talvez seja uma classificação imprecisa no que se refere aos verbos árabes.

Corriente (1992, p. 149) denomina os verbos șaḥiḥ do tipo sālim de verbos de raíz triconsonántica simples ("verbos de raiz triconsonântica simples"), e chama as outras classificações de anomalias morfológicas na flexão verbal.

Ryding (2005, p. 430) atribui o termo regular apenas aos verbos que sejam ao mesmo tempo șahịh e sālim. Para cada um dos outros tipos apresentados ela terá sua opção classificatória, dissociada da proposta árabe.

Cowan (2007, p. 63) concorda em sua classificação com os demais autores, uma vez que chama os verbos șaḥ̂h do tipo sālim de simples.

A razão pela qual a unanimidade dos gramáticos não árabes pesquisados terem unido a dupla classificação árabe șaḥiḥ e sālim em um termo apenas consiste na natureza e no comportamento dos verbos sālim os quais são os fiéis representantes do grupo dos verbos șahịh, uma vez que o suas consoantes radicais permanecem estáveis e inalteradas em qualquer um dos paradigmas flexionais a que sejam submetidas. 
Embora este grupo de verbos atenda ao ideal de regularidade pretendido até mesmo pela gramática portuguesa, visto que o traço delimitador, segundo Azeredo (2010, p. 182) é que o radical do verbo permaneça inalterado, observa-se que esta característica não é exclusividade dos verbos sālim. O radical dos verbos mudac af e mahmūz, que serão estudados a seguir, da mesma forma permanece inalterado, o que muda é o padrão vocálico, no primeiro, e as regras ortográficas, no segundo. Por isso, acredita-se que designar os verbos sālim pelo termo "regular" não individualize esse grupo.

Por isso, sugere-se que seja adotado, em português, o termo verbo triconsonântico simples, assim como proposto por Corriente. Espera-se que pelo adjetivo "simples" entenda-se a ausência de duplicação consonantal e da consoante hamza. 


\subsection{2 مُضَعََّف $m u d a^{c c} a f$}

\begin{tabular}{|c|c|c|c|c|c|}
\hline & Termo & \multicolumn{2}{|c|}{$\begin{array}{c}\text { Possível correspondência } \\
\text { em Pt }\end{array}$} & \multicolumn{2}{|c|}{ Proposta de padronização } \\
\hline \multicolumn{2}{|c|}{ muḍacaf مُضَعََّفَ } & & $\varnothing$ & \multicolumn{2}{|r|}{ Duplicado } \\
\hline \multicolumn{2}{|c|}{$\begin{array}{l}\text { DT: } \\
\text { "Se no verbo houver uma } \\
\text { letra duplicada, o verbo } \\
\text { será chamado de alfid aṣ- } \\
\text { șahīh almudacaf." } 45\end{array}$} & & & \multicolumn{2}{|c|}{$\begin{array}{l}\text { TL: } \\
\text { 1. (re)duplicado, doblado. } \\
\text { 2. Twofold, Double. }\end{array}$} \\
\hline \multicolumn{2}{|c|}{$\begin{array}{l}\text { Ex.: } \\
\text { marra } \\
\text { tamma }\end{array}$} & & & \multicolumn{2}{|c|}{$\begin{array}{l}\text { Fonte: } \\
\text { 1. Corriente, 1991, p. } 459 . \\
\text { 2. Wehr, 1976, p. } 542 .\end{array}$} \\
\hline \multicolumn{2}{|c|}{$\begin{array}{l}\text { Fonte: } \\
\text { Alme arī, 2002, vol. 1, p. } 11 .\end{array}$} & & & & \\
\hline $\mathbf{P t}_{1774}$ & Surdo & $\mathbf{E s}_{1992}$ & $\begin{array}{l}\text { Morfema radical } \\
\{122\}\end{array}$ & Voc $_{1908}$ & --- \\
\hline $\mathbf{P t}_{2007}$ & $\begin{array}{l}\text { Simples duplo } \\
\text { Reduplicado } \\
\text { Geminado }\end{array}$ & $\mathrm{Fr}_{1911}$ & Sourd & Dic $_{1973}$ & Reduplicated \\
\hline $\mathbf{I n}_{1859}$ & $\begin{array}{l}\text { Médio (secundoe) } \\
\text { radicalis } \\
\text { geminatoe } \\
\text { Doubled }\end{array}$ & $\mathbf{I n}_{1965}$ & Doubled & Dic $_{1983}$ & --- \\
\hline $\mathbf{I n}_{2005}$ & $\begin{array}{l}\text { Geminate } \\
\text { Doubled }\end{array}$ & & & & \\
\hline
\end{tabular}

Todos os gramáticos árabes e não árabes investigados concordam quanto à definição do termo Sُضَعَفَف $m u d a^{c c} a f$, como sendo aquele verbo que possui a segunda e terceira radicais idênticas ${ }^{46}$, o que difere entre eles é a classificação proposta.

Abrantes (1774, p. 176), Périer (1911, p. 43), Haywood \& Nahmad (1965, p. 191) e Corriente (1992, p. 178) localizam-no como integrante do grupo dos verbos irregulares. Wright (1859, p. 65) insere-o dentro dos strong verbs ("verbos fortes"); Ryding (2005, p. 430) atribui um grupo a parte a esse tipo de verbo, separado daqueles a

\footnotetext{
45 Tradução nossa de: " (id "ida kāna fí alfì harfun mušaddadun yusammà alfit aș-șahịh almuḍacaf.)

46 Corriente (1992, p. 178) refere-se a estes verbos como os "antigos biconsonânticos". Haywood \& Nahmad (1965, p. 192) sinalizam para a mesma direção quando argumentam que as línguas semíticas eram originalmente bilíteras e não trilíteras, o que indicaria um ancestral comum com as línguas hamíticas. Afirmam ainda que, em árabe, é possível encontrar um grande número de radicais em que a segunda radical se duplicou para se moldar ao padrão trilítero da língua.
} 
que chama de regulares e de irregulares. Cowan (2007, p. 108) parece entendê-los como uma segunda opção para os verbos por ele chamados de "simples". Este gramático aponta ainda que essa classe de verbos não apresenta grandes dificuldades em sua conjugação, porém salienta que certos aspectos exigem a atenção do estudante, os quais estão relacionados com a assimilação ou não das consoantes idênticas ${ }^{47}$.

Verificar-se que não há um consenso em relação às opções terminológicas dos gramáticos não árabes abordados. Os termos nas línguas de chegada estudadas variaram entre surdo, simples duplo, reduplicado, dobrado e geminado. Diferentemente dos demais, Corriente (1992, p. 178) prefere representar o morfema do verbo a sugerir uma terminologia. Diante deste panorama múltiplo, qual seria o termo mais adequado para indicar essa classe de verbos ao leitor especializado brasileiro?

Em seu Dicionário de Linguística e Gramática, Mattoso Câmara (1981, p. 125) define o termo geminado da seguinte forma:

Diz-se da consoante que apresenta uma parte pós-vocálica, decrescente, numa sílaba, e uma parte pré-vocálica, crescente, na sílaba seguinte. Na escrita, indica-se a geminação pela letra dobrada.

Câmara complementa que as consoantes geminadas eram frequentes em latim, contudo, na evolução para o português, passaram a consoantes simples devido ao esvaziamento da consoante pós-vocálica decrescente, por exemplo, bucca $>$ boca, peccare $>$ pecar.

O autor registra ainda que não há vocábulos com consoantes geminadas na língua portuguesa e explica que, até mesmo, os eruditos ${ }^{48}$ foram, desde o início, pronunciados em português como consoantes simples, embora mantivessem, na antiga ortografia, as letras dobradas.

\footnotetext{
${ }^{47}$ As possibilidades de assimilação/dissimilação das consoantes idênticas, segundo Cowan (2007, p. 108):

a. Quando a terceira radical for vocalizada, as consoantes idênticas assimilam-se, e sobre elas, escreve-se o diacrítico šadda _, marcando a duplicação, como em جَ jarra "ele arrastou" (ao invés de جَjarara);

b. Quando a terceira radical não for vocalizada, isto é, sobre ela houver o diacrítico sukūn que simboliza a ausência de vogal, as radicais idênticas serão escritas separadamente, como jarartu "eu arrastei".

${ }^{48}$ Vocábulos latinos introduzidos tardiamente na língua portuguesa por via erudita, por meio social culto que sabia o latim. (Câmara, 1981, p. 108)
} 
Descarta-se a opção geminado, por ser este um termo opaco aos leitores brasileiros contemporâneos, visto que a geminação não figura na gramática da língua portuguesa. Quando um aluno brasileiro estuda vocábulos como carregar, passarinho aprende que o duplo /r/ e /s/ são os dígrafos, isto é, "duas letras que numa ortografia dada servem para indicar um único fonema" (Câmara, 1981, p. 97), a geminação de consoantes não faz parte, assim, da gramática da língua portuguesa.

O termo surdo utilizado tanto por Abrantes (1774, p. 176) quanto por Périer (1991, p. 43), justifica-se devido à mudança do padrão vocálico em que a segunda radical do verbo perde sua vogal breve e recebe sukūn, isto quer dizer que a consoante medial ficaria "ensurdecida", sem vogal. Embora o primeiro deles fosse um gramático português, o termo proposto não evoca nenhuma associação de ideias que possa ajudar o estudante a relacioná-lo com o significante árabe.

Restaram os termos reduplicado e dobrado. Como "reduplicar" em português pode referir-se a algo dobrado duas vezes, quadriplicado, afastando-se da ideia central desta classe de verbos, e "dobrado", embora possa representar o fenômeno de duplicação da segunda consoante, consiste em um vocábulo português polissêmico ${ }^{49}$, sugere-se que o termo duplicado seja adotado para indicar os verbos árabes do tipo muda $a^{c c} a f$.

\footnotetext{
${ }^{49}$ Segundo Houaiss, o lexema dobrar pode significar:

a. Duplicar;

b. Tornar maior, mais intenso;

c. Curvar(-se);

d. Fazer dobras em tecido, papel...;

e. Dominar (alguém ou alguma situação);

f. Mudar a direção, virar.
} 


\subsection{3 نَ mahmūz}

\begin{tabular}{|c|c|c|c|c|c|}
\hline \multicolumn{2}{|c|}{ Termo } & \multicolumn{2}{|c|}{$\begin{array}{c}\text { Possível correspondência } \\
\text { em Pt }\end{array}$} & \multicolumn{2}{|c|}{ Proposta de padronização } \\
\hline \multicolumn{2}{|c|}{ mahmūz مَهْموز } & & $\varnothing$ & & "Hamzado" \\
\hline \multicolumn{2}{|c|}{$\begin{array}{l}\text { DT: } \\
\text { "Se no verbo houver hamza } \\
\text { no seu princípio, no seu } \\
\text { meio ou no seu final, então, } \\
\text { será chamado de alfit aṣ- } \\
\text { șaḥ̂h almahmūz." } 50\end{array}$} & & & \multicolumn{2}{|c|}{$\begin{array}{l}\text { TL: } \\
\begin{aligned} \text { 1. } & \text { Verbo com } \\
& \text { hamza/hamzado. } \\
\text { 2. } & \text { Hamzado. }\end{aligned}\end{array}$} \\
\hline \multicolumn{2}{|c|}{$\begin{array}{l}\text { Ex.: } \\
\text { 'amara } \\
\text { sa'ala } \\
\text { qara'a }\end{array}$} & & & \multicolumn{2}{|c|}{$\begin{array}{c}\text { Fonte: } \\
\text { 1. } \text { Sabbagh, 2011, p. } 695 . \\
\text { 2. }\end{array}$} \\
\hline \multicolumn{2}{|c|}{$\begin{array}{l}\text { Fonte: } \\
\text { Almarī, 2002, vol. 1, p. } 11 .\end{array}$} & & & & \\
\hline $\mathbf{P t}_{1774}$ & Hamzato & $\mathbf{E s}_{1992}$ & $\begin{array}{l}\text { Morfema radical } \\
\left\{{ }^{\prime} 3\right\},\left\{1^{\prime} 3\right\},\left\{12^{\prime}\right\}\end{array}$ & Voc $_{1908}$ & Hamzé \\
\hline $\mathbf{P t}_{2007}$ & $\begin{array}{l}\text { Hamza como } \\
\text { radical }\end{array}$ & $\mathbf{F r}_{1911}$ & Hamzé & Dic $_{1973}$ & Hèmzatum \\
\hline $\mathbf{I n}_{1859}$ & Hèmzatum & $\mathbf{I n}_{1965}$ & Hamzated & Dic $_{1983}$ & Glottalized \\
\hline
\end{tabular}

A consoante chamada em árabe de hamza é descrita como oclusiva, laríngea, surda (Jubran, 2004, p. 23). Lipiński ${ }^{51}$ (1997, p. 141) registra que o protossemítico ${ }^{52}$ já contava com o fonema laríngeo /R/, e, com a evolução das línguas semíticas, esse fonema permaneceu tal como original em algumas das línguas descendentes, como é o caso do árabe (p.148).

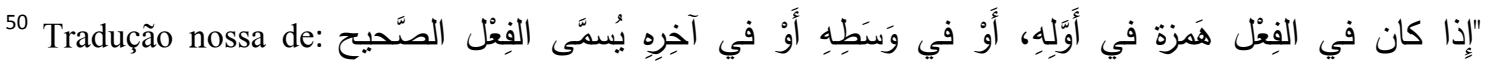

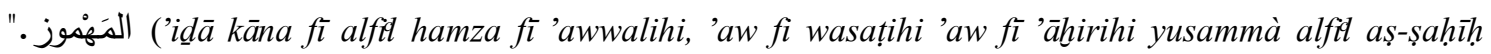
almahmūz .)

${ }^{51}$ Lipiński (1997) realizou um estudo gramatical comparativo da família das línguas semíticas, no qual mostra a evolução de diferentes aspectos linguísticos desde o protossemítico até o estágio contemporâneo das línguas em foco.

${ }^{52}$ Ressalta-se que o protossemítico seria uma língua homogênea da qual descenderam as línguas semíticas, diz-se "seria" porque não há comprovação documental de sua existência além das línguas que dela vieram. Lipiński (1997, p. 41) afirma que este é mais do que um nome convencional dado ao grupo de elementos compartilhados pela família sob consideração. Para ele, este conceito poderia ser comparado ao latim, com respeito às línguas românicas. 
Observa-se que a transposição do termo árabe مَهْهوز mahmūz para cada uma das línguas de chegada foi homogênea, isto porque o fonema representado pela consoante hamza se encontra ausente do quadro consonantal das línguas portuguesa, espanhola, francesa e inglesa. Desta maneira, a estratégia dos gramáticos foi criar um neônimo, ou termo neológico, para indicar essa categoria de verbos.

Os gramáticos árabes situam essa classe de verbos dentro daqueles chamados de șaḥịh, como apresentado em seção anterior, porém, cada gramático não árabe possui uma classificação própria.

Abrantes (1774, p.185) situa-os no grupo dos verbos imperfeitos e irregulares, no entanto, diz que sua conjugação é "da mesma sorte que o Verbo Perfeito" (p. 186), devendo ser respeitadas as regras de escrita do hamza.

Wright (1859, p.69) localiza-os como um dos dois tipos do weak verbs ou verba infirma ("verbos fracos").

Périer (1911, p. 47) chama-os de irregulares e acrescenta que a particularidade destes verbos vem da mudança que a "letra fraca", suporte do hamza $a^{53}$, pode sofrer.

Haywood \& Nahmad (1965, p. 199) classificam os verbos mahmūz como irregulares, salientando que a dificuldade principal que envolve essa classe é a ortografia do hamza, uma vez que pode ser escrito sobre o 'alif (أَ أ أُ إl (l) sob o 'alif), sobre o $w \bar{a} w(\mathfrak{g})$ e sobre o $y \bar{a}^{\prime}(\mathfrak{s})^{54}$.

Corriente (1992, p. 177) não sugere uma terminologia para esses verbos, antes, representa o morfema de suas raízes. $\mathrm{O}$ autor afirma que as variações meramente ortográficas do suporte do hamza são condicionadas pelo entorno vocálico da raiz verbal.

\footnotetext{
${ }^{53}$ Chamam-se de suporte (ou apoio) do hamza as três vogais longas (l'alif, و wāw e $y \bar{a}^{\prime}$ ) que sustentam esta consoante na escrita. As vogais longas são definidas de acordo com regras ortográficas específicas e com o padrão vocálico do paradigma nominal ou verbal da palavra formada.

${ }^{54}$ Para um aprofundamento nas regras ortográficas da consoante hamza, consulte Haywood \& Nahmad (1965, p. $199-200)$, Wightwick \& Gaatar (2008, p.38).
} 
Para Ryding (2005, p. 431), esse grupo de verbos é considerado uma categoria separada devido às regras morfofonêmicas ${ }^{55}$ que governam a ocorrência e distribuição do hamza, como também por suas regras ortográficas.

Cowan (2007, p. 113) não indica um termo específico para denominar essa classe, prefere o sintagma terminológico "verbos com hamza como radical" para expressá-los. O autor atesta que a conjugação destes verbos é totalmente regular e que o hamza possui um valor consonântico pleno.

Nota-se que apenas o termo "glottalized", sugerido em A Dictionary of Modern Linguistic Terms (Bakalla et al. 1983, p. 97), destoa dos demais apresentados. O termo faz referência à zona de articulação do fonema /R/, produzido na laringe. Lipiński (1997, p. 141) atesta que este fonema é frequentemente classificado sob o título de gutural, um termo que tem sido bem aceito em diversos círculos, embora não o descreva precisamente do ponto de vista de sua articulação, uma vez que sua classificação precisa é fonema oclusivo, laríngeo, surdo, conforme mencionado anteriormente.

Assim, sugere-se que seja adotado, em português, o termo "hamzado" para indicar o verbo mahmūz, por se tratar de um uso convencional entre os gramáticos pesquisados e também porque este termo já se encontra dicionarizado com a acepção específica desejada. Acredita-se, portanto, que "hamzado" seja aparente e claro ao leitor especializado, transmitindo de imediato a ideia central dessa classe de verbos.

55 Segundo Mattoso Câmara (1981, p. 171), morfofonêmica consiste na "parte da linguística descritiva que estuda a distribuição das variantes posicionais das formas linguísticas em juntura (...)". 


\subsection{Ss muctal}

\begin{tabular}{|c|c|c|c|c|c|}
\hline \multicolumn{2}{|r|}{ Termo } & \multicolumn{2}{|c|}{$\begin{array}{c}\text { Possível correspondência } \\
\text { em Pt }\end{array}$} & \multicolumn{2}{|c|}{ Proposta de padronização } \\
\hline \multicolumn{2}{|c|}{ מعُنَّictal } & \multicolumn{2}{|c|}{ Irregular } & \multicolumn{2}{|c|}{$\begin{array}{c}\text { Consonântico- } \\
\text { semiconsonântico }\end{array}$} \\
\hline \multicolumn{2}{|c|}{$\begin{array}{l}\text { DT: } \\
\text { "É aquele que contém uma } \\
\text { ou duas semiconsoantes." }\end{array}$} & \multicolumn{2}{|c|}{$\begin{array}{l}\text { DT: } \\
\text { "Irregular é, ao contrário, } \\
\text { todo o verbo que apresenta } \\
\text { algum desvio em relação ao } \\
\text { modelo, ou paradigma, de } \\
\text { sua conjugação. São } \\
\text { irregulares verbos como dar } \\
\text { (cf. dou, deste em face de } \\
\text { canto, cantaste), perder (cf. } \\
\text { perco/perde em face de } \\
\text { bato/bate) e caber (cf. } \\
\text { caibo/cabe/coube em face de } \\
\text { bato/bate/bati)." }\end{array}$} & \multicolumn{2}{|c|}{$\begin{aligned} \text { TL: } & \\
\text { 1. } & \text { Enfermo, débil. } \\
& \text { Defectuoso. Defectivo. } \\
\text { 2. } & \text { Enfermo, dolente, } \\
& \text { doente. Com vogal } \\
& \text { (verbo). }\end{aligned}$} \\
\hline \multicolumn{2}{|c|}{$\begin{array}{l}\text { Ex.: } \\
\text { wajada/ qāla/ ramà } \\
\text { rawà /wafă }\end{array}$} & \multicolumn{2}{|c|}{$\begin{array}{l}\text { Ex.: } \\
\text { dar/ perder/ caber }\end{array}$} & \multicolumn{2}{|c|}{$\begin{aligned} \text { Fonte: } & \\
\text { 1. } & \text { Corriente, 1991, p. } \\
& 528 . \\
\text { 2. } & \text { Sabbagh, 2011, p. } \\
& 656 .\end{aligned}$} \\
\hline \multicolumn{2}{|c|}{$\begin{array}{l}\text { Fonte: } \\
\text { Ad-dīn }{ }^{\mathrm{c}} \mathrm{Am}{ }^{\mathrm{c}} \mathrm{Al} \overline{1}, 2006, \mathrm{p} . \\
195 .\end{array}$} & \multicolumn{2}{|c|}{$\begin{array}{l}\text { Fonte } \\
\text { Azeredo, 2010, p. } 182 .\end{array}$} & & \\
\hline $\mathbf{P t}_{1774}$ & $\begin{array}{l}\text { Irregular e } \\
\text { imperfeito }\end{array}$ & Es $_{1992}$ & --- & Voc $_{1908}$ & Infirme, irrégulier \\
\hline $\mathbf{P t}_{\mathbf{2 0 0 7}}$ & --- & $\operatorname{Fr}_{1911}$ & $\begin{array}{l}\text { Irrégulier } \\
\text { Verbes à lettres } \\
\text { faibles }\end{array}$ & Dic $_{1973}$ & $\begin{array}{l}\text { Weak } \\
\text { Verbum infirmum } \\
\text { unsound }\end{array}$ \\
\hline $\operatorname{In}_{1859}$ & $\begin{array}{l}\text { Weak } \\
\text { Verbum infirmum }\end{array}$ & $\operatorname{In}_{1965}$ & Irregular & Dic $_{1983}$ & --- \\
\hline $\operatorname{In}_{2005}$ & $\begin{array}{l}\text { Roots with semi- } \\
\text { consonants }\end{array}$ & & & & \\
\hline
\end{tabular}

A ficha terminológica acima apresenta um panorama heterogêneo quanto aos termos adotados pelos gramáticos estudados, que variam entre irregular e imperfeito, enfermo/fraco, verbos com semiconsoante, verbos com letras fracas.

Haywood \& Nahmad (1965, p. 191), ao abrirem o capítulo 24 - "Irregular Verbs"- de sua gramática, introduzem a ideia de que o termo irregular talvez seja impreciso e inadequado para expressar o verbo árabe, se pelo termo for compreendido idiossincrasias isoladas, uma vez que há toda uma classe de verbos em que certas

\footnotetext{
${ }^{56}$ Tradução nossa de: "هو ما كان فيه حَرف عِلّة أَو حَرْفان" (huwa mā kāna fìhi harfu illa 'aw harfān).
} 
alterações e desvios do paradigma ocorrem, devido a contrações e assimilações de radicais. Segundo eles, uma das causas para essas mudanças na raiz é a presença de uma "letra fraca" (weak letter) como uma das consoantes radicais do lexema ${ }^{57}$.

Périer (1911, p. 43) estabelece uma comparação entre o que seria a irregularidade verbal em francês e em árabe. Em francês, segundo ele, os verbos irregulares possuem radicais diferentes ou ocorrem alterações das formas originais das raízes quando estas são conjugadas nas diferentes pessoas do discurso. Em árabe, um verbo não admite vários radicais, nem a conjugação nas pessoas do discurso apresenta grandes dificuldades. Todas as anomalias são provenientes, entre outras ${ }^{58}$, da alteração que sofrem as semiconsoantes empregadas como parte integrante da raiz do verbo.

Em português, a irregularidade verbal é semelhante ao francês. Um verbo da língua portuguesa é chamado de irregular quando, em algumas formas, apresenta variação no radical ou na flexão, afastando-se do modelo da conjugação a que pertence (Bechara, 1999, p. 225). Os gramáticos tradicionais costumam classificar os verbos irregulares em três grupos:

a) Irregulares fracos: aqueles que podem mudar de radical, sem aparente explicação, ao variar a pessoa (Azeredo, 2010, p. 183). Exemplo: perder perco e perde; medir - meço e mede.

b) Irregulares fortes: aqueles que apresentam no pretérito perfeito um radical diverso do presente (Azeredo, 2010, p. 183). Exemplo: dizer dizes e disseste; saber - sabes e soubeste.

c) Irregulares anômalos: aqueles que apresentam diversidade total de radicais entre tempos ou mesmo entre pessoas do mesmo tempo (Azeredo, 2010, p. 183). São representantes deste grupo apenas os verbos ser e ir. Bechara (1999, p. 226) explica que a irregularidade desses verbos acontece porque ambos reúnem radicais primários diferentes - ser

\footnotetext{
${ }^{57}$ Haywood \& Nahmad (1965, p. 191) listam entre as causas das mudanças da raiz a presença da consoante hamza e de duas consoantes duplicadas, isso porque eles classificam os verbos duplicados e "hamzados" como verbos irregulares.

${ }^{58}$ Périer (1911, p. 47), assim como Haywood \& Nahmad (1965, p. 191), classifica os verbos duplicados e "hamzados" como verbos irregulares, por isso consideram que tanto a presença do hamza como de uma consoante duplica dê origem a anomalias na raiz verbal.
} 
é o resultado da união dos verbos latinos sedēre e ěsse; e ir reúne três radicais latinos ire, vadēre e ěsse.

Mattoso Câmara (1981, p. 148) define irregularidade como um "conceito da gramática descritiva, referente às formas linguísticas que ficam fora do paradigma correspondente às demais da mesma estrutura" (grifo nosso).

Em árabe, os verbos classificados como sُ $m u^{c} t a l$ possuem um paradigma próprio de conjugação, devido à existência das semiconsoantes na constituição da raiz. A presença do $w \bar{a} w$ e $y \bar{a}^{\prime}$ como consoantes radicais destes verbos exigem que sua flexão seja diferenciada daqueles chamados, nesta dissertação, de puramente consonânticos.

Os verbos $m u^{c} t a l$, em que uma das semiconsoantes ocorre na primeira radical, conjugam-se de acordo com regras específicas. Já aqueles verbos, em que uma das semiconsoantes for a consoante central, seguem outras recomendações. E, por último,

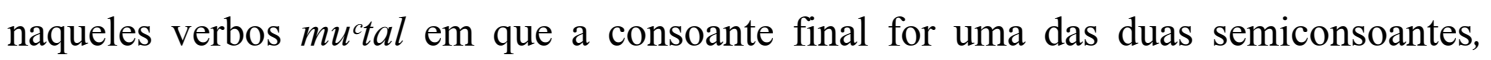
regras determinadas deverão ser observadas.

É importante esclarecer que o parâmetro flexional é o mesmo para todas as classes de verbos árabes, isto é, todos têm por princípio a conjugação dos verbos șaḥ̄h do tipo sālim, chamados de triconsonântico simples neste trabalho, contudo, por causa das características inerentes de cada raiz, alterações ao parâmetro comum acontecem.

Chega-se a duas questões antagônicas, pois, ao mesmo tempo em que se observa "irregularidade" nos verbos $\mathrm{mu}^{c} t a l$, se comparados com o comportamento dos verbos puramente consonânticos, eles não "ficam fora do paradigma correspondente aos demais da mesma estrutura" (Câmara, 1981, p. 148). Por isso, acredita-se ser pertinete afastar o termo irregular para designar esse grupo de verbos.

O que caracteriza, então, o comportamento peculiar dessa classe é a presença das semiconsoantes $w \bar{a} w$ ou $y \bar{a}^{\prime}$ como constituinte da raiz verbal. Esta é a característica primordial e que motiva as transformações pelas quais as raízes passam. Por essa razão, sugere-se que a classe dos verbos $m u^{c} t a l$ seja referida, em português, por consonânticoseminconsonântico, alertando o leitor especializado, por meio da terminologia, que estes verbos são constituídos por consoantes, mas também, por semiconsoantes. 
A classificação genuína árabe opõe os verbos șaḥiḥ e $m u^{c} t a l$, como os grandes representantes de seus grupos. A terminologia proposta puramente consonântico e consonântico-semiconsonântico, respectivamente, além de manter a classificação dos árabes, valoriza a simetria entre os novos termos, um artifício didático que pretende auxiliar o leitor especializado e interessado na compreensão das terminologias verbais árabes.

\subsection{1 منثِال mitâl}

\begin{tabular}{|c|c|c|c|c|c|}
\hline \multicolumn{2}{|c|}{ Termo } & \multicolumn{2}{|c|}{$\begin{array}{c}\text { Possível correspondência } \\
\text { em Pt }\end{array}$} & \multicolumn{2}{|c|}{ Proposta de Padronização } \\
\hline \multicolumn{2}{|r|}{ mițāl مِنال } & & $\varnothing$ & \multicolumn{2}{|c|}{$\begin{array}{c}\text { Verbo com gou ي como } 1^{\text {a }} \\
\text { radical }\end{array}$} \\
\hline \multicolumn{2}{|c|}{$\begin{array}{l}\text { DT: } \\
\text { "O mitāal é aquele cuja } \\
\text { primeira radical é uma } \\
\text { semiconsoante." }\end{array}$} & & & \multicolumn{2}{|c|}{$\begin{aligned} \text { TL: } & \\
\text { 1. } & \text { Modelo, tipo, ejemplo. } \\
\text { 2. } & \text { Exemplo, modelo. Ideal, } \\
& \text { padrão, paradigma, } \\
& \text { norma. }\end{aligned}$} \\
\hline \multicolumn{2}{|c|}{$\begin{array}{l}\text { Ex.: } \\
\text { wajada/yabisa }\end{array}$} & & & \multicolumn{2}{|c|}{$\begin{array}{l}\text { Fonte: } \\
\text { 1. Corriente, 1991, p. } 708 . \\
\text { 2. } \text { Sabbagh, 2011, p. } 603 .\end{array}$} \\
\hline \multicolumn{2}{|c|}{$\begin{array}{l}\text { Fonte: } \\
\text { Ad-dīn }{ }^{\mathrm{C} A m}{ }^{\mathrm{c} A l \overline{1}}, 2006, \mathrm{p} . \\
195 .\end{array}$} & & & & \\
\hline $\mathbf{P t}_{1774}$ & $\begin{array}{l}\text { Quiescente }{ }^{60} \text { ف } \\
\text { Símile }\end{array}$ & $\mathbf{E s}_{1992}$ & $\begin{array}{l}\text { Morfema radical } \\
\{w 23\} .\{y 23\}\end{array}$ & Voc $_{1908}$ & Assimilé \\
\hline $\mathbf{P t}_{2007}$ & $\begin{array}{l}\text { Verbo com و ou } \\
\text { ي como } 1^{\mathrm{a}} \text { radical }\end{array}$ & $\mathbf{F r}_{1911}$ & Assimilé & Dic $_{1973}$ & $\begin{array}{l}\text { Paradigm. Quasi- } \\
\text { sound }\end{array}$ \\
\hline $\operatorname{In}_{1859}$ & $\begin{array}{l}\text { Verbumprimoe } \\
\text { radicalis g et }\end{array}$ & $\operatorname{In}_{1965}$ & Assimilated & Dic $_{1983}$ & --- \\
\hline $\mathbf{I n}_{2005}$ & Assimilated & & & & \\
\hline
\end{tabular}

O verbete assimilar, na língua portuguesa, está assim descrito por Ferreira (1986, p. 148):

\footnotetext{
${ }^{59}$ Tradução nossa de: "المِنال: هو ما كانَ أَوَّل حُروفه حَرْف عِلَّة. (almitāl huwa mā kāna 'awwal hurüfihi harfa illa.)

60 "Quiescente [Do lat. quiescente]. Adj. 2 g. 1. Que está em descanso. 2. Que está sereno, tranquilo." (Ferreira, 1986, p. 1173)
} 
[Do lat. assimilare] V.t.d. 1. Tornar semelhante ou igual; assemelhar. 2. Apropriar-se, compenetrar-se de (ideia, sentimento, etc.) (...) 3. Compenetrarse de; fixar, apreender, aprender (ideias, ensinamentos): (...) 4. Fisiol. (...) 5. Gram. Dar lugar à assimilação ${ }^{61}$. (...)

Dentre as acepções listadas acima, as relevantes para esse estudo são as de número 1 e 5 . A primeira delas reflete o significado da raiz primária de $J$ م $m-\underline{t}-l$ de onde se deriva o termo مِثِال mițāl e diversos outros lexemas que, de alguma forma, perpassam a ideia central de semelhança, similitude, como, por exemplo,

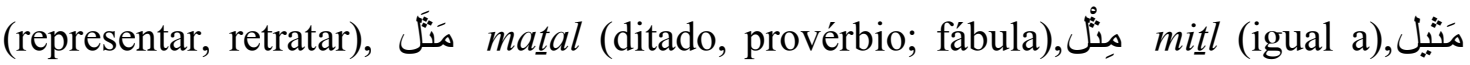
mațīl (semelhante, similar; equivalente, par).

A quinta acepção direciona-se exatamente para a ciência gramatical e apresenta o processo fonético da assimilação, que, segundo Grammont (1933 apud Câmara 1981, p. 62), “consiste na extensão de um ou vários movimentos articulatórios além de seu domínio originário", isto é, um fonema adquire traços articulatórios novos pela influência de outro contíguo. Mattoso Câmara acrescenta que, na evolução da língua portuguesa, a assimilação desempenhou papel importantíssimo, como fenômeno de sonorização, vocalização, palatalização e fechamento de timbre de ditongo decrescente assimilado pelas semivogais ${ }^{62}$ (/layte/, de lacte- $>$ leite; tauru- $i>$ touro).

Embora semas semelhantes sejam observados entre os termos مِثَال mitâal e "assimilado", este não expressa concretamente o comportamento das semiconsoantes presentes nesta classe de verbos. De acordo com a DT selecionada na ficha terminológica, os verbos do tipo مِ mițâl são aqueles que possuem como primeira consoante radical uma das semiconsoantes $w \bar{a} w$ ou $y \bar{a}$. Todos os gramáticos pesquisados concordam que aqueles verbos iniciados por $y \bar{a}$ ' apresentam um sistema flexional regular, isto quer dizer que a seminconsoante se mantém inalterada nas diferentes flexões, por possuir um valor consonântico pleno.

\footnotetext{
61 "Transformação dum fonema em outro, seguinte: esse ( $<$ lat. ipse), nosso $(<$ nosso $<$ nostro $<$ lat. nostru), ou precedente: enteado (< antenatu)." (Ferreira, 1986, p. 148)

${ }^{62}$ De acordo com a definição de Mattoso Câmara (1981, p. 217), uma semivogal é uma "vogal assilábica que acompanha a base de uma sílaba para constituir um ditongo descrescente.”
} 
Alterações na raiz verbal ocorrem quando o $w \bar{a} w$ é a primeira radical e, que sob certas condições, será elidido. Wright (1859, p. 74) explica que aqueles verbos iniciados por $w \bar{a} w$ e que seguem o paradigma facala yacilu rejeitam a semiconsoante nas formas de "presente do indicativo" e "imperativo". Como exemplo, observe a tabela 5 abaixo:

\begin{tabular}{|c|c|c|c|}
\hline "Imperativo" & $\begin{array}{l}\text { "Presente do } \\
\text { indicativo" }\end{array}$ & $\begin{array}{l}\text { "Pretérito } \\
\text { perfeito" }\end{array}$ & Tradução \\
\hline quتَ quت & يَقفة yaqifu & وَقَفَت waqafa & Parar,estacionar \\
\hline عِدْ cid & يَعِدُ yacidu & w wَعَدَ wac $^{c} a d a$ & Prometer \\
\hline s sِ sِلْ & yașilu & wوصَلَ waṣala & Chegar \\
\hline
\end{tabular}

Tabela 5: Tabela ilustrativa do paradigma focala yafilu, cujo wāw é a primeira radical

Verbos que seguem o paradigma facila yafiilu, ao invés de yacalu, também rejeitam a semiconsoante na forma de "presente do indicativo" وَرِتَ بَرِتُ (herdar) e وَفِقِ يَفِق wafiqa yafiqu (prosperar), porém, tanto os verbos que seguem o paradigma facila yac $a^{c}{ }^{63}$ e os chamados, nesta dissertação, de duplicados conservarão o $w \bar{a} w$ na forma de "presente do indicativo", como, por exemplo, وَجْلَ يَوْجَلُ wajila

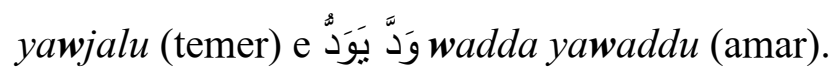

Constata-se, portanto, que a elisão ou a permanência do $w \bar{a} w$ está relacionado com o padrão vocálico do paradigma flexional a que o verbo faz parte e não com o processo fonético de assimilação no qual a semiconsoante adquire traços articulatórios do fonema subsequente e se torna a ele semelhante.

\footnotetext{
${ }^{63}$ Apenas um grupo de oito verbos que seguem o paradigma facala yafcalu rejeita o wāw na forma "presente do indicativo", Wright (1859) justifica a elisão da semiconsoante pela presença de uma consoante 'gutural' ou 'semigutural' como segunda ou terceira radical. Para lista completa, veja Wright (1859, p. 75).
} 
Dentre os sete gramáticos pesquisados, encontra-se um posicionamento equilibrado quanto aos termos adotados para indicar os verbos do tipo مِثنال mitâal. Périer (1911, p. 55), Haywood \& Nahmad (1965, p. 215) e Ryding (2005, p. 431) optaram pela denominação "verbo assimilado". Ryding (2005, p. 460) ensina que o esses verbos são assim chamados em inglês porque, apesar do $w \bar{a} w$ inicial fazer parte da raiz, frequentemente desaparece, é elidido ou assimilado pelo prefixo marcador do sujeito. Vê-se, porém, que o termo "assimilado" não é exclusividade dos falantes de língua inglesa, foi adotado também pelos franceses, como registra Périer (1911).

Wright (1859, p. 74), Corriente (1992, p. 179) e Cowan (2007, p. 114) preferem empregar uma estrutura composta para expressar os verbos em questão. $\mathrm{O}$ sintagma terminológico "Verba primae radicalis g et ي", "morfema radical $\{\mathrm{w} 23\}$, $\{\mathrm{y} 23\} "$ e "verbos com g como $1^{\mathrm{a}}$ radical" descrevem a característica principal destes verbos e sinalizam ao leitor especializado qual deverá ser sua postura e tratamento diante dos mesmos.

Abrantes (1774, p. 192) propôs o termo principal quiescente $\dot{\Theta}$, em que $f \vec{a}$ ' refere-se à primeira consoante radical, e o termo símile, referência direta ao termo árabe مِثنال mitâl. O termo quiescente para Abrantes (1774, p. 24) indica quando as "letras débeis" l'alif, و $و$ wâw e $y \bar{a}$ ' não recebem nenhum tipo de diacrítico. No capítulo reservado ao verbo símile, o autor não justifica o motivo de chamar essa classe de quiescente $\dot{\omega}$, o qual parece ser um termo inadequado, já que a semiconsoante participante da raiz está submetido ao padrão vocálico verbal, formado pelas vogais breves.

Das opções encontradas nas gramáticas não árabes, acredita-se que os compostos tenham sido os mais aparentes e precisos no papel de expressar essa classe de verbos ao leitor especializado. Por isso, sugere-se que, em português, seja adotada a fraseologia especializada verbos com و ou como $1^{\text {a }}$ radical, ao invés de delimitar um termo único que se afaste ou tangencie a característica principal desse grupo, e 
incorra no risco de não alcançar um dos objetivos desta dissertação que é auxiliar o estudante no percurso de aprendizagem da língua árabe.

\subsection{2 أَجوَف 1.jajwaf}

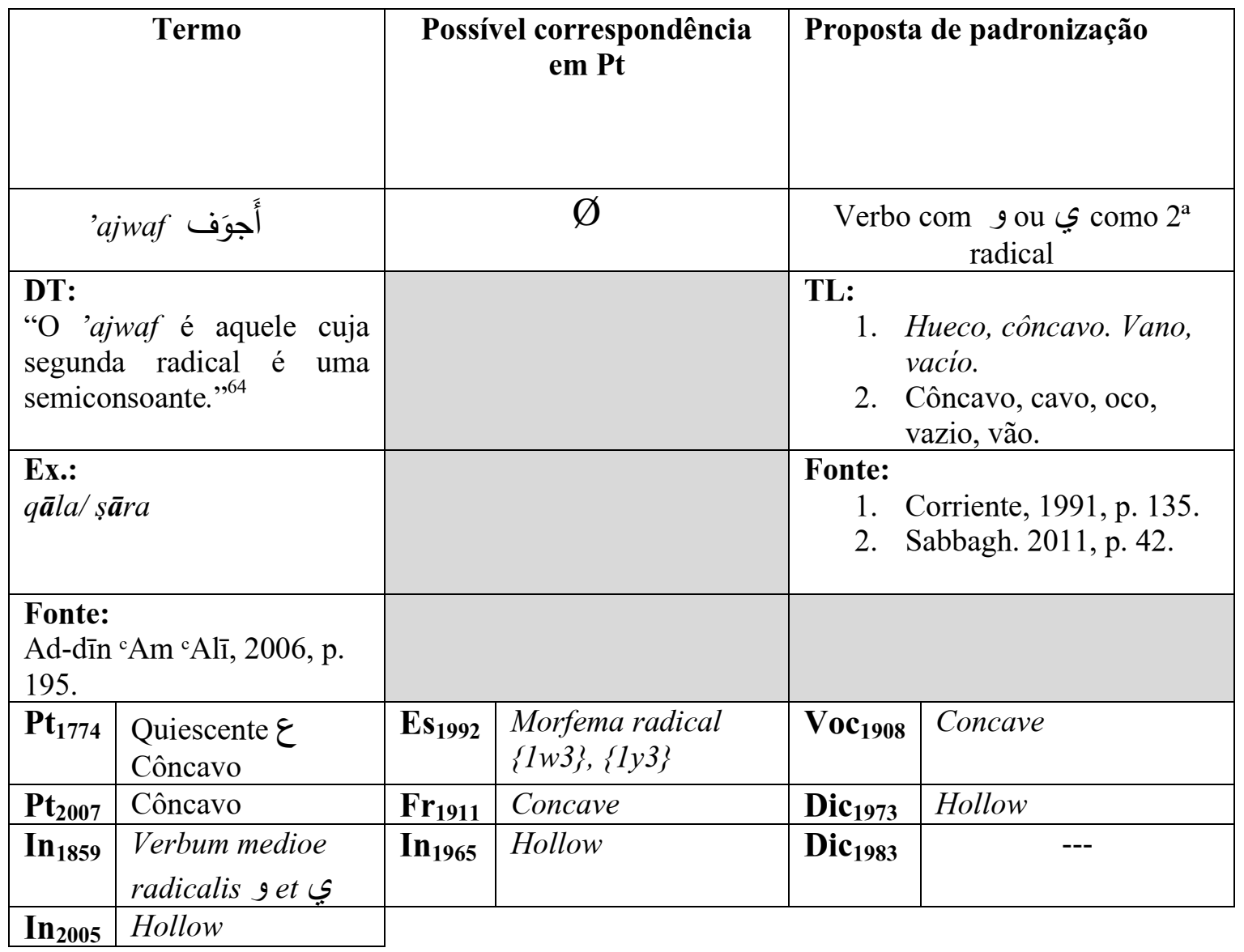

Ao analisar a ficha terminológica acima, observa-se que o termo côncavo, hollow e concave são traduções diretas do termo árabe أَجَوَف 'ajwaf. Algo côncavo indica algo vazio, oco por dentro. Trazendo essa ideia para a proposta classificatória dos verbos árabes, entende-se que um verbo 'ajwaf seria aquele que possui seu meio ou sua posição medial vazia.

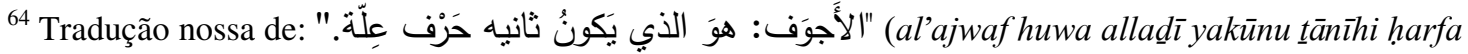
illa.)
} 
O que na realidade acontece com esses verbos é que sua segunda consoante radical genuína, $w \bar{a} w$ ou $y \bar{a}$ ', passa por uma série de mutações previstas e registradas, transformando-se em 'alif, vogal longa, vogal breve e hamza ${ }^{65}$ (Ryding, 2005, p. 431). O caráter instável próprio das semiconsoantes e o padrão vocálico dos paradigmas flexionais são os responsáveis pelas alterações morfológicas elencadas.

Cada gramático não árabe estudado registra as mesmas regras que regem a mutação das semiconsoantes, cada qual seguindo seu parâmetro e sua metodologia, porém, são unânimes nos aspectos abaixo:

a) Quando três sílabas abertas seguirem-se em sucessão imediata e a primeira delas for obrigatoriamente vocalizada em fatha, as semiconsoantes $w \bar{a} w$ ou $y \bar{a}$ ' serão transformadas na vogal longa l 'alif . Exemplo:

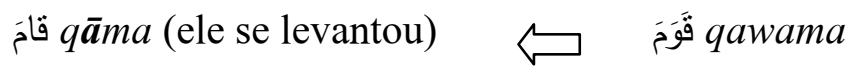

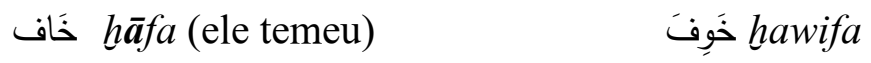

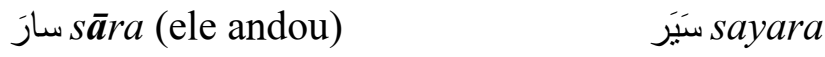

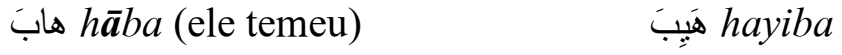

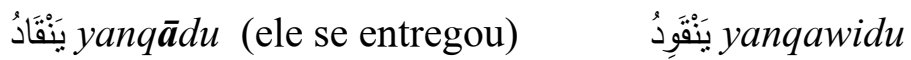

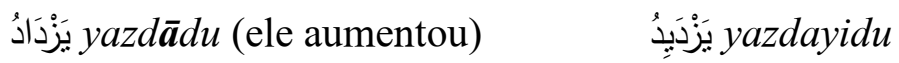

b) Se a primeira radical do verbo for vocalizada, isto é, receber sukūn, as semiconsoantes recuam sua vocalização (sua vogal breve) para a primeira e transformam-se em vogais longas ('alif, wāw e $y \bar{a}$ ') homólogas à vogal breve que a primeira consoante recebeu. Exemplo:

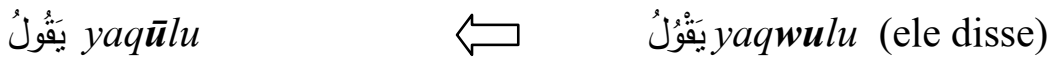

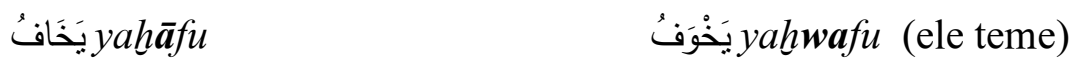

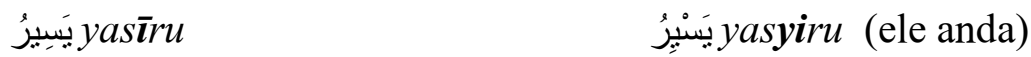

\footnotetext{
${ }^{65}$ Para uma análise pormenorizada desta classe de verbos, ver Wright (1859, p. 78), Haywood \& Nahmad (1965, p. 224), Périer (1911, p. 60).
} 
yَyah $y a \bar{a} b u$

يَهْيَبْ yahyabu (ele teme)

c) Se a terceira consoante radical receber o sukūn, três situações podem ocorrer:

a. Na conjugação do "presente do indicativo", as vogais longas 'alif, wāw e $y \bar{a}$ ' são elididas porque sílabas fechadas não admitem vogal longa.

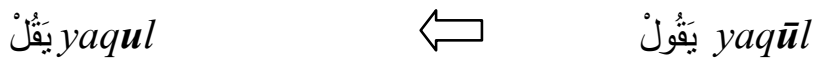

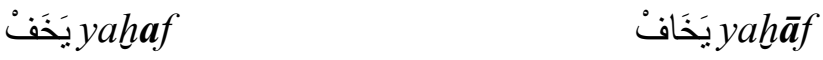

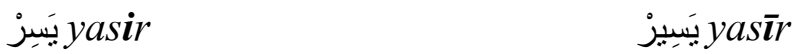

b. No "pretérito perfeito", as semiconsoantes $w \bar{a} w$ e $y \bar{a}$ ' serão elididas, juntamente com sua vocalização, porém modificam a vogal breve $a$ (fatha) da primeira consoante em $u$ (damma) ou $i$ (kasra), respectivamente.

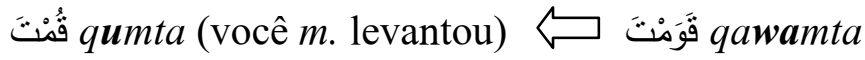

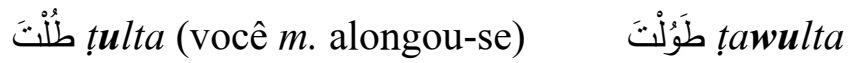

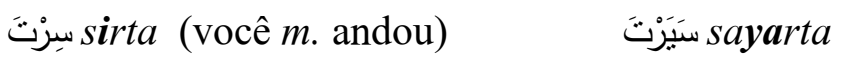

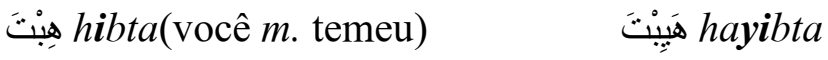

c. Se a semiconsoante $w \bar{a} w$ for vocalizada em $i$ (kasra) também será elidida, porém sua influência modifica a vogal breve $a$ (fatha) da primeira radical, passando a $i$ (kasra).

\section{خِ hifta

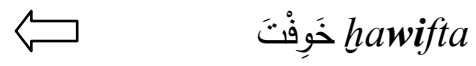

d) As semiconsoantes $w \bar{a} w$ e $y \bar{a}$ ' serão modificadas em hamza, devido ao paradigma do "particípio ativo". Exemplo:

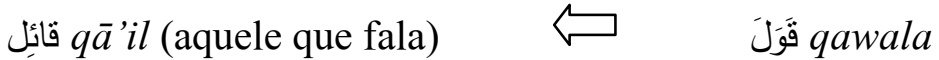

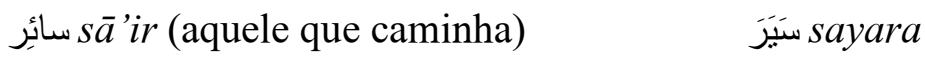


Outras alterações morfológicas ocorrem para atender, também, aos padrões vocálicos de paradigmas verbais, como na forma passiva do "pretérito perfeito", em que é previsto o padrão vocálico $u$ (damma) na primeira radical e um $i$ (kasra) na segunda. Esta última vogal breve modifica as semiconsoantes $w \bar{a} w$ e $y \bar{a}$ ' em $y \bar{a}$ ' e, por harmonização vocálica ${ }^{66}$, o $u$ (damma) da primeira consoante radical é também modificado em $i$ (kasra), como ilustrado abaixo:

\section{qîlla (foi dito) قُقِلَ quwila}

Verifica-se, portanto, que as alterações que ocorrem com as semiconsoantes localizadas na segunda radical do verbo são determinadas, em muito, pelo padrão vocálico do paradigma desejado. Abrantes (1774, p. 24) afirma que as "letras débeis" mudam-se, muitas vezes, por causa de suas próprias vogais, ou da que imediatamente lhes precede. Por isso que a ideia de concavidade não é suficiente para denotar essa classe de verbos, uma vez que, mesmo que a posição de segunda radical fique vazia em virtude das regras acima descritas, sua marca é evidenciada na primeira consoante radical. Assim, propõe-se que a fraseologia especializada verbos com و $و$ ou como $2^{a}$ radical seja adotado em português, pois sua significação é aparente ao leitor especializado, além disso, traça-se um paralelo didático e terminológico com os verbos que possuem as semiconsoantes na primeira radical.

${ }^{66}$ Segundo Mattoso Câmara (1981, p. 134) harmonização vocálica é a mudança do timbre de uma vogal pretônica para harmonizar-se com o da vogal tônica. 
1.2.3 ناقِصَnqis

\begin{tabular}{|c|c|c|c|c|c|}
\hline \multicolumn{2}{|c|}{ Termo } & \multirow{2}{*}{\multicolumn{2}{|c|}{$\begin{array}{c}\begin{array}{c}\text { Possível correspondência } \\
\text { em Pt }\end{array} \\
\text { Defectivo }\end{array}$}} & \multirow{2}{*}{\multicolumn{2}{|c|}{$\begin{array}{c}\text { Proposta de padronização } \\
\text { Verbo com و ou como } 3^{\mathrm{a}} \\
\text { radical }\end{array}$}} \\
\hline \multicolumn{2}{|c|}{ nāqiṣ ناقِص } & & & & \\
\hline \multicolumn{2}{|c|}{$\begin{array}{l}\text { DT: } \\
\text { "O nāqiṣ é aquele cuja } \\
\text { terceira radical é uma } \\
\text { semiconsoante." } 67\end{array}$} & \multicolumn{2}{|c|}{$\begin{array}{l}\text { DT: } \\
\text { "Chamam-se defectivos } \text { os } \\
\text { verbos a que faltam algumas } \\
\text { formas do paradigma." }\end{array}$} & \multicolumn{2}{|c|}{$\begin{array}{ll}\text { TL: } & \\
\text { 1. } & \text { Incompleto. Defectivo } \\
& \text { [gr]. Defectuoso. } \\
\text { 2. } & \text { Defeituoso, } \\
& \text { incompleto. Defectivo } \\
& \text { (verbo). }\end{array}$} \\
\hline \multicolumn{2}{|c|}{$\begin{array}{l}\text { Ex.: } \\
\text { dac } \overline{\boldsymbol{a}} / \text { radiya/ ramì }\end{array}$} & \multicolumn{2}{|c|}{$\begin{array}{l}\text { Ex.: } \\
\text { colorir/ demolir/ abolir }\end{array}$} & \multicolumn{2}{|c|}{$\begin{array}{l}\text { Fonte: } \\
\text { 1. Corriente, 1991, p. } 779 \\
\text { 2. Sabbagh, 2011, p. } 706 . \\
\end{array}$} \\
\hline \multicolumn{2}{|c|}{$\begin{array}{l}\text { Fonte: } \\
\text { Ad-dīn }{ }^{\mathrm{c}} \mathrm{Am}{ }^{\mathrm{c}} \mathrm{Al} \overline{1}, 2006, \mathrm{p} . \\
196 .\end{array}$} & \multicolumn{2}{|c|}{$\begin{array}{l}\text { Fonte: } \\
\text { Azeredo, 2010, p. } 183 .\end{array}$} & \multicolumn{2}{|c|}{ (n) } \\
\hline $\mathbf{P t}_{1774}$ & $\begin{array}{l}\text { Quiescente J } \\
\text { Defectivo }\end{array}$ & Es $_{1992}$ & $\begin{array}{l}\text { Morfema radical } \\
\{12 w\},\{12 y\}\end{array}$ & Voc $_{1908}$ & Défectueux \\
\hline $\mathbf{P t}_{2007}$ & Fraco & $\mathbf{F r}_{1911}$ & Défectueux ${ }^{68}$ & Dic $_{1973}$ & Defective \\
\hline $\mathbf{I n}_{1859}$ & $\begin{array}{l}\text { Verbs of which the } \\
\text { third radical is و } \\
\text { or ي } \\
\text { Verbum tertio } \\
\text { radicalis و et } \\
\text { ي }\end{array}$ & $\operatorname{In}_{1965}$ & $\begin{array}{l}\text { The verb with the } \\
\text { weak final radical } \\
\text { Defective }\end{array}$ & Dic $_{1983}$ & Defective \\
\hline $\mathbf{I n}_{2005}$ & Defective & & & & \\
\hline
\end{tabular}

Se a finalidade desta análise fosse a tradução literal do termo árabe, ficaria acordado que o termo defectivo, proposto pela maioria dos autores pesquisados, trata-se da terminologia exata para referir-se a essa classe de verbos, no entanto, "fazer terminologia (...) não (...) é traduzir.” (Cabré apud Barros, 2004, p. 17).

O termo defectivo não reflete a realidade desta classe, uma vez que os verbos nāqiṣ possuem seu paradigma flexional completo. Eles são caracterizados por

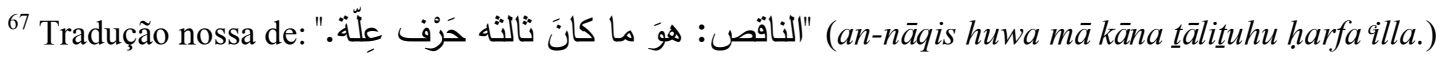

${ }^{68}$ Isto é "defeituoso". (Côrrea, 1970, p. 163)
} 
alterações morfológicas sistemáticas na terceira radical do verbo. Todos os autores pesquisados descrevem as mesmas regras, cada qual utilizando sua metodologia própria. Primou-se pela descrição de Ryding por sua clareza didática ao tratar do tema.

Ryding (2005, p. 463) classifica os verbos nāqiṣ em dois:

a. Aqueles terminados com a semiconsoante $w \bar{a} w$ que serão escritas com 'alif na forma de "pretérito perfeito":

\begin{tabular}{|c|c|c|c|}
\hline Paradigma & Raiz & $\begin{array}{l}\text { "Pretérito } \\
\text { perfeito" }\end{array}$ & Tradução \\
\hline $\begin{array}{l}\text { facala } \\
\text { فَعَلَ yafaculu }\end{array}$ & $\begin{array}{l}\text { دَعَوَ } \\
d a^{c} a w a\end{array}$ & $\begin{array}{l}d a^{c} \bar{a} \\
d{ }^{\prime}\end{array}$ & Convidar \\
\hline $\begin{array}{l}\text { facala } \\
\text { فَعَلَ yَafaculu }\end{array}$ & 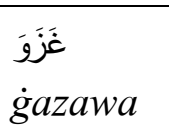 & 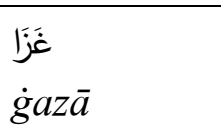 & Conquistar \\
\hline
\end{tabular}

b. Aqueles terminados em $y \bar{a}^{\prime}$. Há duas categorias para os verbos nāqiș com $y \bar{a}$ ' como terceira radical, um terminado em $ى$ 'alif maqșūra (bi șūrat alyā ${ }^{, 69}$ ) na forma do "pretérito perfeito", em que o $y \bar{a}$ ' é restaurado na forma do "presente do indicativo"; o outro é seu oposto, isto é, o yā' mantém-se como última radical no "pretérito perfeito" e o 'alif maqșuta aparece na forma de "presente do indicativo".

c.

\begin{tabular}{|c|c|c|c|c|}
\hline d.aradigma & Raiz & $\begin{array}{l}\text { "Pretérito } \\
\text { perfeito" }\end{array}$ & $\begin{array}{l}\text { "Presente do } \\
\text { indicativo" }\end{array}$ & Tradução \\
\hline $\begin{array}{l}\text { facala } \\
\text { فَعَلَ yafacilu }\end{array}$ & رَمَيَ & $\begin{array}{l}\text { رَمَىى } \\
\text { ramà }\end{array}$ & يََّْْمِي & Arremessar \\
\hline $\begin{array}{l}\text { فَ facila } \\
\text { فَعِلَ yafacalu }\end{array}$ & لَقَيَ & لَقَيَ & 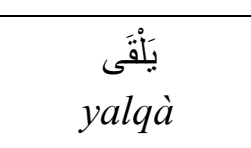 & Encontrar \\
\hline
\end{tabular}

\footnotetext{
${ }^{69}$ Literalmente: 'alif maqșūra à imagem do $y \bar{a}$ '. (Cowan, 2007, p. 129)
} 
As semiconsoantes $w \bar{a} w$ e $y \bar{a}$ ' serão elididas quando o verbo for flexionado em paradigmas que prevejam o diacrítico sukūn sobre a terceira radical, como é o caso, por exemplo, da $2^{\mathrm{a}}$ pessoa do masculino singular do "imperativo".
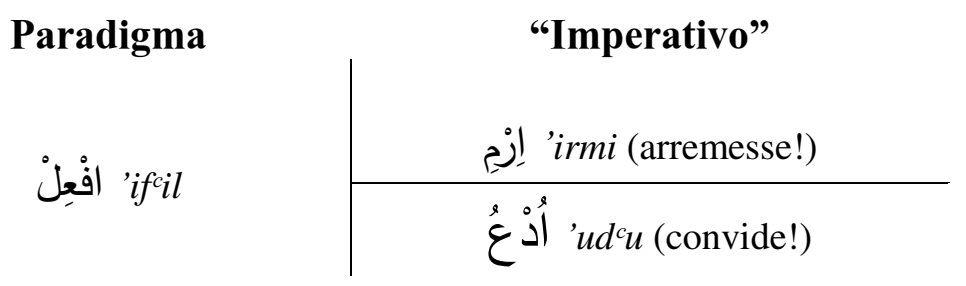

Mais uma vez, observa-se que o padrão vocálico dos paradigmas verbais desempenha papel importante na alteração morfológica das semiconsoantes e determina qual a forma que as mesmas assumirão na raiz. A fim de ratificar esse argumento, citase o verbo رَضِيَ يَرْضنى radiya yarḍà (estar contente), que parece pertencer à segunda categoria proposta pela Ryding (2005, p. 463), no entanto, este verbo tem como raiz رَضِوَ fadiwa e segue o paradigma فَحِلَ falla. Neste, a vogal breve da segunda radical influencia a semiconsoante subsequente, modificando-a para $y \bar{a}$, a partir daí, este verbo seguirá as regras flexionais do grupo a ele semelhante.

Desaconselha-se, então, o uso do termo "defectivo", em português, para expressar esta classe de verbos árabes, uma vez que ambos os fatos gramaticais árabe e português não apresentam correspondênica.

Os verbos defectivos da língua portuguesa são aqueles "a que faltam algumas formas do paradigma”, como afirma Azeredo (2010, p. 183). Segundo o mesmo autor, a defasagem formal é devida à ausência da forma de primeira pessoa do singular do presente do indicativo, o que acarreta a inexistência de todo o presente do subjuntivo. Em árabe, os verbos nāqiṣ, denominados de "defectivos" por alguns gramáticos não árabes, são aqueles que possuem as semiconsoantes $w \bar{a} w$ ou $y \bar{a}$ ' como terceira radical. Estes verbos possuem o paradigma flexional completo.

É interessante notar a opção do gramático francês Périer (1911, p.68) para designar esses verbos, ele usa o vocábulo francês défectueux, que em a tradução literal significa “defeituoso". Ele utiliza o termo défectif para indicar o verbo لَيْنَ laysa ("não ser/ não estar") que de fato possui características defectivas, segundo a definição de 
Azeredo (2010, p. 183), pois se conjuga apenas no "pretérito perfeito", embora sua tradução corresponda ao presente do indicativo português.

Observa-se que os semas principais das definições terminológicas árabes e portuguesas são conflitantes, inviabilizando o termo "defectivo". Propõe-se, assim, a fraseologia especializada verbos com $و \boldsymbol{w} \overline{\boldsymbol{a}} \boldsymbol{w}$ ou $y \bar{a}$ ' como $3^{\mathrm{a}}$ radical para denominar os verbos da classe nāqiș, mantendo-se o paralelo com os termos adotados nos outros dois casos para indicar as posições possíveis das semiconsoantes na raiz verbal. 


\subsection{4 لفيف حَقْرون lafíf maqrūn}

\begin{tabular}{|c|c|c|c|c|c|}
\hline \multirow{2}{*}{\multicolumn{2}{|c|}{ 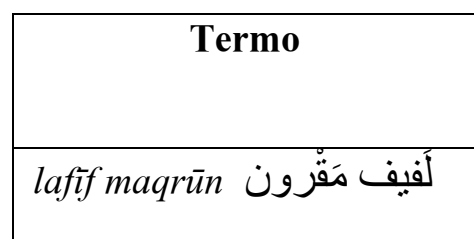 }} & \multicolumn{2}{|c|}{$\begin{array}{c}\text { Possível correspondência } \\
\text { em Pt }\end{array}$} & \multicolumn{2}{|c|}{ Proposta de padronização } \\
\hline & & & $\varnothing$ & Verbo co & $\begin{array}{l}\mathrm{m} \text { duas semiconsoantes } \\
\text { consecutivas }\end{array}$ \\
\hline \multicolumn{2}{|c|}{$\begin{array}{l}\text { DT: } \\
\text { "O lafif maqrūn é aquele } \\
\text { que contém } \\
\text { semiconsoantes duas } \\
\text { consecutivas." }\end{array}$} & & & \multicolumn{2}{|c|}{$\begin{aligned} \text { TL }^{71}: & \\
\text { 1. } & \text { a. Gathered, assembled. } \\
& \text { Mixed. b. Conected, } \\
& \text { joined, linked. } \\
\text { 2. } & \text { a. Mezclado, } \\
& \text { complicado. b. Unido, } \\
& \text { acoplado. }\end{aligned}$} \\
\hline \multicolumn{2}{|c|}{$\begin{array}{l}\text { Ex.: } \\
\text { hawà / lawà }\end{array}$} & & & \multicolumn{2}{|c|}{$\begin{aligned} \text { Fonte: } & \\
\text { 1. } & \text { Wehr, 1976, p. 871/760. } \\
\text { 2. } & \text { Corriente, 1991, p. } \\
& 694 / 621 .\end{aligned}$} \\
\hline \multicolumn{2}{|c|}{$\begin{array}{l}\text { Fonte: } \\
\text { Ad-dīn }{ }^{\mathrm{c} A m}{ }^{\mathrm{c}} \mathrm{Alī}, 2006, \mathrm{p} . \\
196 .\end{array}$} & & & & \\
\hline $\mathbf{P t}_{1774}$ & $\begin{array}{l}\text { Verbo de dous } \\
\text { modos imperfeito } \\
\text { junto } \\
\text { Verbo envolto } \\
\text { junto }\end{array}$ & $\mathbf{E s}_{1992}$ & $\begin{array}{l}\text { Raices doblemente } \\
\text { peculiares }\end{array}$ & Voc $_{1908}$ & $\begin{array}{l}\text { Verb irrégulier dont } \\
\text { lês deux letters se } \\
\text { suivent comme }\end{array}$ \\
\hline $\mathbf{P t}_{2007}$ & $\begin{array}{l}\text { Dupla } \\
\text { irregularidade }\end{array}$ & $\mathbf{F r}_{1911}$ & $\begin{array}{l}\text { Verbe a plusieurs } \\
\text { irrégularités }\end{array}$ & Dic $_{1973}$ & --- \\
\hline $\mathbf{I n}_{1859}$ & $\begin{array}{l}\text { Verbs that are } \\
\text { doubly weak }\end{array}$ & $\operatorname{In}_{1965}$ & Doubly weak verb & Dic $_{1983}$ & $\begin{array}{l}-- \\
\end{array}$ \\
\hline $\mathbf{I n}_{2005}$ & $\begin{array}{l}\text { Doubly weak } \\
\text { "Mixed" verb root }\end{array}$ & & & & \\
\hline
\end{tabular}

Os filólogos árabes denominam لفيف lafif os verbos cuja raiz é composta pelas duas semiconsoantes $w \bar{a} w$ e $y \bar{a}$ ' simultaneamente. Estes são segmentados em duas categorias, a primeira delas indica aqueles verbos em que as semiconsoantes são contíguas, ocupando os radicais medial e final, esta classe chama-se لفيف مَقْرون lafiff

\footnotetext{
70 Tradução nossa de: " اللَفيف المَقرون: وهو الذي يكون فيه حَرفا علّة مُنتاليان (al-lafíf almaqrūn wahuwa allad̄i yakūnu fìhi harfāilla mutatalīāni.)

${ }^{71}$ Como o termo principal em questão é composto por dois vocábulos, decidiu-se subdividir os itens 1 . e 2. (referente às fontes consultadas) em a. e b., a fim de indicar a significação de cada termo em particular. Esta metodologia será utilizada nos próximos termos compostos.
} 
maqrūn. A segunda classe, denominada لفيف مَفْروق lafif mafrūq, refere-se àqueles verbos cujas semiconsoantes são intercaladas por uma "consoante forte/ plena", assim, o $w \bar{a} w$ e o $y \bar{a}$ ' podem ocupar tanto a primeira quanto a terceira consoante radical $^{72}$.

Haywood \& Nahmad (1965, p. 250) afirmam que ambas as classes são de rara ocorrência, contudo, incluem verbos de uso corriqueiro, por isso seu estudo é pertinente.

É comum encontrar análises que incluam a consoante hamza no grupo das "letras fracas" e considerem os verbos que possuem o $w \bar{a} w$, o yā e a hamza como "triplamente irregulares ou fracos". Dos sete autores pesquisados, apenas dois, a saber, Abrantes (1774, p. 237) e Cowan (2007, p. 133) seguem a proposta tradicional árabe, considerando apenas as semiconsoantes como formadoras da classe لفيف lafiff.

Observa-se que não há um consenso entre os gramáticos não árabes estudados quanto à terminologia para designar especificamente o verbo lafíf maqrūn, apenas Abrantes (1774, p. 237) e Machuel (1908, p. 55) restringem os termos adotados, empregando, por exemplo, os vocábulos junto e se suivent $t^{73}$. As referências terminológicas dos outros autores são genéricas, a diferenciação entre as duas classes se dá a partir da explicação e exemplificação dos verbos.

Os termos genéricos para as duas categorias do verbo lafif adotados pelos autores abordados sugerem dois semas diferentes: a irregularidade verbal e a instabilidade de suas consoantes radicais. Viu-se acima que o termo irregular não expressa exatamente o que se passa com os verbos constituídos por semiconsoantes, pois estes seguem o modelo flexional próprio de seu grupo, em que as alterações morfológicas são previstas e determinadas pelo padrão vocálico do paradigma desejado.

O termo "fraco" origina-se na tradição gramatical árabe, que chama de "letras fracas" as vogais longas 'alif, wāw e $y \bar{a}$. Denominar o verbo لفيف lafif como “duplamente fraco" poderia ser uma solução em português, todavia é possível que este

\footnotetext{
${ }^{72}$ Para uma explicação pormenorizada do funcionamento dos verbos لفيف لفيف مَقْرون lafíf maqrūn e مَفْروق lafíf mafrūq, vide Abrantes (1774, p. 237), Wright (1859, p. 91) e Périer (1911, 76).

${ }^{73}$ Lit. "se seguem". (Côrrea, 1970, p. 560)
} 
termo não evoque o significante árabe no leitor interessado de maneira imediata. Por isso que, para indicar o verbo لفيف مَفْرْون lafíf maqrūn em português, sugere-se a fraseologia verbo com duas semiconsoantes consecutivas, uma estrutura mais longa, no entanto, mais aparente. 


\subsection{5 لفيف حَفْروق lafíf mafrūq}

\begin{tabular}{|c|c|c|c|c|c|}
\hline \multirow{2}{*}{\multicolumn{2}{|c|}{\begin{tabular}{|c|} 
Termo \\
لَفِف مَفْروق lafíf mafrūq
\end{tabular}}} & \multicolumn{2}{|c|}{$\begin{array}{c}\text { Possível correspondência } \\
\text { em Pt }\end{array}$} & \multicolumn{2}{|c|}{ Proposta de padronização } \\
\hline & & & $\varnothing$ & Verbo c & $\begin{array}{l}\text { m duas semiconsoantes } \\
\text { intercaladas }\end{array}$ \\
\hline \multicolumn{2}{|c|}{$\begin{array}{l}\text { DT: } \\
\text { "O lafif mafrūq é aquele } \\
\text { que contém } \\
\text { semiconsoantes } \\
\text { consecutivas." }\end{array}$} & & & \multicolumn{2}{|c|}{$\begin{array}{l}\text { TL: } \\
\text { 1. } \\
\text { a. Gathered, assembled. } \\
\\
\text { Mixed. b. Separated, } \\
\text { divided. } \\
\text { 2. } \\
\text { a. Mezclado, } \\
\text { complicado. b. separado, } \\
\text { fendido, dividido. }\end{array}$} \\
\hline \multicolumn{2}{|c|}{$\begin{array}{l}\text { Ex.: } \\
\text { wafă /waqà }\end{array}$} & & & \multicolumn{2}{|c|}{$\begin{array}{l}\text { Fonte: } \\
\begin{array}{l}\text { 1. Wehr, 1976, p. 871/708. } \\
\text { 2. Corriente, 1991, p. } \\
\text { 694/583. }\end{array}\end{array}$} \\
\hline \multicolumn{2}{|c|}{$\begin{array}{l}\text { Fonte: } \\
\text { Ad-dīn }{ }^{\mathrm{c}} \mathrm{Am}{ }^{\mathrm{c}} \mathrm{Al} \overline{1}, 2006, \mathrm{p} . \\
196 .\end{array}$} & & & & \\
\hline $\mathbf{P t}_{1774}$ & $\begin{array}{l}\text { Verbo de dous } \\
\text { modos imperfeito } \\
\text { separado } \\
\text { Verbo envolto } \\
\text { separado }\end{array}$ & $\mathbf{E s}_{1992}$ & $\begin{array}{l}\text { Raices doblemente } \\
\text { peculiares }\end{array}$ & Voc $_{1908}$ & $\begin{array}{l}\text { Verb irrégulier, ayant } \\
\text { um intervalle entre Le } \\
\text { deux lettres, comme } \\
\text { وَشَىى }\end{array}$ \\
\hline $\mathbf{P t}_{2007}$ & $\begin{array}{l}\text { Dupla } \\
\text { irregularidade }\end{array}$ & $\mathbf{F r}_{1911}$ & $\begin{array}{l}\text { Verbe a plusieurs } \\
\text { irrégularités }\end{array}$ & Dic $_{1973}$ & --- \\
\hline $\mathbf{I n}_{1859}$ & $\begin{array}{l}\text { Verbs that are } \\
\text { doubly weak }\end{array}$ & $\mathbf{I n}_{1965}$ & Doubly weak verb & Dic $_{1983}$ & --- \\
\hline $\mathbf{I n}_{2005}$ & $\begin{array}{l}\text { Doubly weak } \\
\text { "Mixed" verb root }\end{array}$ & & & & \\
\hline
\end{tabular}

A linha de raciocínio que rege a análise deste termo é a mesma seguida no termo lafïf maqrūn descrito anteriormente. Os lexemas árabes maqrūn ("ligado, unido") e mafrūq ("separado, dividido") qualificam o termo principal lafíf (mesclado, misturado), no qual as consoantes ditas fortes e as semiconsoantes estão presentes na raiz verbal, em posição consecutiva ou intercalada.

\footnotetext{
${ }^{74}$ Tradução nossa de: "اللَفيف المَفروق: وهو الذي يكون فيه حَرفا علّة غَير مُنتاليين. (al-lafíf almafrūq wahuwa allad̄i yakūnu fìhi harfầilla gayr mutataliyayni.)
} 
Igualmente ao termo discutido em 1.2.4, a maioria dos autores pesquisados não diferencia terminologicamente as categorias maqrūn e mafrūq, empregando um termo que sinalize a dupla irregularidade ou instabilidade da raiz. Apenas Abrantes (1774, p. 245) e Machuel (1908, p. 55) registram a diferença tipológica deste grupo.

Seguindo os mesmos argumentos usados no item anterior, sugere-se, então, a adoção da fraseologia verbo com duas semiconsoantes intercaladas para designar o verbo lafï mafrūq em português.

Com o intuito de retomar a padronização em língua portuguesa das classes tipológicas das raízes verbais árabes, propõe-se a tabela 6:

\begin{tabular}{|c|c|}
\hline $\begin{array}{l}\text { Verbos Puramente } \\
\text { Consonânticos }\end{array}$ & $\begin{array}{l}\text { Verbos Consonânticos e } \\
\text { Semiconsonânticos }\end{array}$ \\
\hline Triconsonântico simples & Verbo com و ou como $1^{a}$ radical \\
\hline Duplicado & Verbo com و ou como 2 2adical ral \\
\hline \multirow[t]{3}{*}{ "Hamzado" } & Verbo com و ou como $3^{\mathrm{a}}$ radical \\
\hline & $\begin{array}{l}\text { Verbo com duas semiconsoantes } \\
\text { consecutivas }\end{array}$ \\
\hline & $\begin{array}{l}\text { Verbo com duas semiconsoantes } \\
\text { intercaladas }\end{array}$ \\
\hline
\end{tabular}

Tabela 6: Tipologia das raízes verbais árabes 


\section{O tempo, o aspecto e o modo verbal árabe e português: um}

\section{panorama}

$\mathrm{O}$ verbo possui duas perspectivas, são elas, o fato e o tempo. (...) $\mathrm{O}$ que indica um fato completo e transcorrido num tempo anterior, é chamado de الفعل الماضي alficl almāộ̄. O que indica um fato incompleto que ocorre no tempo atual ou ocorrerá no futuro, chama-se de الفعل المضارع alficl almuḍāric. O que indica um pedido que acontecerá no futuro chama-se فعل الأمر ficl al'amr. A referência temporal do verbo é o momento da enunciação, então o que se der antes será passado e depois indicará o futuro. ${ }^{75}$ (Alhatīib \& Jațal, 1992, p.142) (Tradução nossa)

$\mathrm{Na}$ descrição do verbo árabe proposta por Alhatî̉b \& Jaṭal (1992, p.142), observam-se as categorias de tempo ("tempo anterior", "tempo atual" e "posterior ao momento da enunciação"), de aspecto ("fato completo" X "incompleto") e de modo ("o que indica pedido"), categorias estas também presentes no sistema verbal português. Outra característica importante na delimitação do tempo em ambas as línguas é o momento da enunciação, isto é, a ocasião em que se dá o ato de fala ou de escrita (Azeredo, 2010, p. 353).

Castilho (2010, p. 418) confirma a proposição dos gramáticos supracitados e postula que o tempo é uma propriedade cuja interpretação deve ser remetida ao momento da enunciação. Ao tomar o sujeito enunciador como referencial, é possível entender as fatias de tempo passado, presente, futuro e representar a anterioridade, simultaneidade e a posterioridade do evento narrado.

Azeredo (2010, p. 353, 358) apresenta variáveis relevantes na compreensão das relações de tempo expressas nas sentenças em português, que também podem ser úteis na compreensão do conceito temporal das frases árabes. São elas:

\footnotetext{
" يدلّ الفعل على أمرين هما الحدث والزمان، (...) ما دلّ على حدث نّّ، ومضى زمنه، ويسمى: الفعل 75

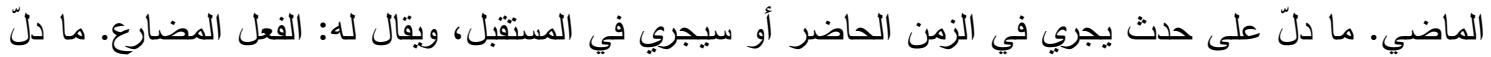

على طلب عمل، سيقع في المستقبل، وهو فعل الأمر • والمقياس الزماني في دلالة الفعل هو لحظة التكلم، فما وقع قبلها كان ماضياً، وما يقع بعدها يُعَدُّ مُستقبلاً."

(yadullu alficl calà 'amrayn humā alhadat wazzamān, (...) mā dalla calà hadat tamma, wamaḍa zamanahu yusamà: alficl almādi. mā dalla calà hadat yajirì fizz-zaman 'aw sayajirī fìl-mustaqbal wa yuqāl lahu: alficl almudāricic. mā dalla calā țalbi camalin, sayaqa'u fil-mustaqbali wa huwa ficl al'amr. walmiqyās

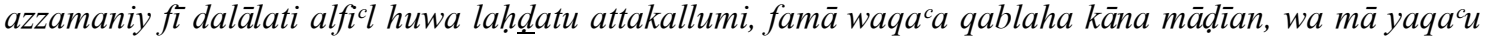
bacdaha yucaddu mustaqbalan).
} 
a) O momento da enunciação;

b) O ponto de referência, isto é, cada uma das etapas (presente, passado, futuro) nas quais se divide a linha do tempo e que ordena a temporalidade das ações expressas;

c) $\mathrm{A}$ perfectividade (concluso) $\mathrm{X}$ imperfectividade (inconcluso) do processo denotado pelo verbo.

Tais variáveis são essenciais na delimitação exata do evento expresso na linha do tempo. O momento da enunciação pode coincidir ou não com o ponto de referência, como em:

(1) ya'kulu Zaydu attufāhata.

Zayd come a maçã.

O verbo ya'kulu/ come tanto em português como em árabe expressa um evento não concluído que está em processo no momento da enunciação, quando a situação de fala/escrita é simultânea à mensagem expressa pelo verbo.

(2) sayadhabu Zaydu 'ilà almadrasati ġadan.

Zayd irá à escola amanhã.

(3) kataba Zaydu alwadifata.

Zayd escreveu o dever.

Os verbos sayadhabu/ irá e kataba/ escreveu indicam que o momento da enunciação não coincide com o ponto de referência expresso pelos verbos. Em (2), o processo é posterior, indicando uma ação futura e, por isso, ainda inconclusa. Em (3) é anterior, referindo-se a um fato passado e totalmente concluído ${ }^{76}$.

As noções de tempo, aspecto e modo configuram-se diferentemente nas línguas estudadas. Enquanto o português dispõe de um quadro flexional extenso e preciso para designar as diferentes noções de tempo passado, presente e futuro; o árabe, como outras

\footnotetext{
76 “(...) não utilizamos as formas temporais unicamente para fixar cronologias dos estados de coisas, situando-nos num tempo real, mensurável pelo relógio (...) e, sim, igualmente, para deslocarmos livremente pela linha do tempo, de acordo com nossas necessidades expressivas, refugiando-nos num tempo imaginário, que escapa à medição cronológica, ou num domínio vago, genérico, impreciso, atemporal." (Castilho, 2010, p. 432)
} 
línguas semíticas, apresenta perspectiva temporal diversa e seu quadro flexional é reduzido, assim como não há significações temporais tão precisas, como nas línguas indoeuropeias (Haywood \& Nahmad, 1965, p. 96), contudo, isso não quer dizer que não seja possível transpor, do português para o árabe, sentenças do tipo:

(4) O funcionário saíra do escritório, quando o chefe o chamou. kana almūaddafu qad gadara almaktaba cindama țalabahu ar-ra'iīs.

Embora não haja, em árabe, uma forma única correspondente para o tempo pretérito mais-que-perfeito simples do indicativo português - saíra, utiliza-se a construção perifrástica (kana + o verbo principal no passado acabado) a fim de denotar um evento concluído e situado em um intervalo de tempo anterior ao ponto de referência passado. Assim, mesmo possuindo um quadro flexional limitado em relação ao português, a língua árabe dispõe de mecanismos que viabilizam expressar as mesmas noções de tempo, como ilustrado no exemplo (4).

Partindo do princípio de que o objetivo primordial desta pesquisa é auxiliar o leitor especializado brasileiro na compreensão dos termos gramaticais do verbo árabe e propor uma padronização destas terminologias, é nosso propósito tentar aproximar, ao máximo, o universo verbal árabe da realidade terminológica dos consulentes lusófonos. Antes, porém, faz-se necessário delimitar os conceitos de tempo, aspecto e modo verbal em ambas as línguas, a fim de verificar até que ponto é possível traçar correspondências e não incorrer em propostas incoerentes.

Lipiński (1997, p. 331), ao estudar comparativamente a gramática das línguas semíticas, comenta que os questionamentos levantados acerca dos verbos estão entre os mais complicados da linguística semítica e que a variada terminologia empregada nos estudos gramaticais não colabora para sua compreensão. $O$ pesquisador critica o posicionamento de autores que chamam formas verbais correspondentes nas diferentes línguas semíticas de "subjuntivo", "jussivo", "coortativo"77, "modal”. Acrescenta ainda que a tendência das análises linguísticas contemporâneas sobre o tempo indo-europeu pode levar a interpretações inadequadas de características básicas do sistema verbal

\footnotetext{
${ }^{77}$ Kelly (1998, p. 166) afirma que o modo coortativo é usado, na gramática do hebraico bíblico, para expressar desejo, intenção, autoencorajamento ou intenção do sujeito de realizar certa ação. O modo jussivo, tanto em hebraico quanto em árabe, é usado para expressar vontade, desejo ou ordem de quem fala. Segundo Dubois et al. (1973, p. 314 apud Moura (org.) 1999, p. 405) os elementos modalizadores são considerados os meios pelos quais um falante manifesta o modo como ele considera seu próprio enunciado, como, por exemplo, o verbo modal dever que exprime uma obrigação além da probabilidade.
} 
semítico, como a distinção entre transitivo e intransitivo, ativo e estativo e o aspecto da ação semítica.

Ainda segundo Lipiński (1997, p. 332), a categoria gramatical do tempo semítico apresenta distinção apenas entre uma ação passada e outra futura. Esta distinção bipartida (passado/futuro) forma "um tipo de tempo" que indica a ordem relativa dos eventos, por exemplo, se algum evento já ocorreu antes do tempo real (ou fictício) da enunciação ou ainda não aconteceu. O autor afirma que a distinção bipartida é comum em um grande número de línguas e que a distinção tripartida entre o passado, o presente e o futuro não é uma característica universal das línguas naturais.

Para o pesquisador supracitado (1997, p. 332), a categoria gramatical do aspecto semítico indica a condição ou a situação das circunstâncias, se elas são permanentes, estáticas, completas ou incompletas.

A categoria de modo denota a maneira como uma ação ou um estado é expresso. Lipiński (1997, p. 333) observa que o modo dos verbos semíticos, chamados de "indicativo", "subjuntivo", "jussivo", "enérgico" são meramente categorias morfossintáticas de coordenação e subordinação ${ }^{78 ;}$ marcadas ou não marcadas por sufixos. Essa diferenciação, em árabe, ocorre da seguinte forma: o modo "indicativo" é marcado pelo diacrítico damma (-u) colocado sobre a última consoante radical do verbo, o "subjuntivo" pelo fatha (-a), o "jussivo" é a forma não marcada, uma vez que o diacrítico característico é o sukūn que indica ausência de vogal breve.

O mesmo autor (1997, p. 335) salienta que a categoria de tempo, no sentido próprio da palavra, está longe de ser comum a qualquer tipo do sistema verbal semítico, entretanto, utilizar a noção de tempo existente nas línguas europeias é a única forma de traduzir o aspecto semítico de maneira inteligível. O assim chamado "presente" ou "futuro" árabe é na realidade o aspecto imperfectivo, indicando basicamente que um processo ainda não alcançou sua completude no momento da enunciação. Este pode também indicar que uma atividade ainda está em progresso ou que um estado está sofrendo a influência de outra atividade ou de outro estado. Em português, podemos traduzi-lo, por exemplo, por presente do indicativo - simples e contínuo, mesmo que o português brasileiro não disponha de uma terminologia para o presente perifrástico/contínuo (Castilho, 2010, p. 431). O chamado "passado" indica o aspecto

\footnotetext{
${ }^{78}$ Em árabe, para que haja a flexão no modo subjuntivo e "jussivo", é necessário que ao verbo mudạaric sejam antepostas partículas específicas que modificam a significação indicativa, como se verificará mais adiante.
} 
perfectivo, indicando que o evento já alcançou sua completude em um tempo anterior à situação de fala/escrita. Dependendo da construção - simples ou perifrástica - tem-se o pretérito perfeito ou mais-que-perfeito do indicativo, por exemplo.

A posição de Wright (1967 apud Ryding, 2005, p. 440) corrobora a argumentação acima ao propor que:

"O perfectivo ou o imperfectivo semítico, por si só, não faz referência às relações temporais do falante (pensador ou escritor) nem de outras ações apresentadas em justaposição a ele. São estas relações precisamente que determinarão em que esfera de tempo (passado, presente ou futuro) o perfectivo ou imperfectivo semítico ficará e por quais de nossos tempos será expresso - se pelo nosso passado, perfeito, mais-que-perfeito, ou futuro do pretérito; pelo nosso presente, imperfeito ou futuro ${ }^{79} . "-$ (Tradução nossa)

Ryding (2005, p. 440) cita que o Árabe Clássico, em teoria, era mais aspectoespecífico do que tempo-específico, contudo, ao lidar com o Árabe Moderno Padrão, alguns linguístas e professores acreditam ser mais pragmático descrever os verbos árabes de acordo com as relações de tempo. Lipiński (1997, p. 346) ratifica esse argumento e acrescenta que a formação dos tempos nas línguas semíticas modernas desenvolveu-se em imitação ao sistema verbal indo-europeu. $\mathrm{O}$ autor afirma ainda que os tempos compostos são parcialmente baseados em formações arcaicas usadas para refletir aspectos particulares e não relações temporais.

A presente pesquisa posiciona-se na vertente tempo-específica, por considerála menos confusa aos aprendizes da língua árabe. Pretende-se, assim, evitar que um estudante, ao se deparar com o termo "imperfectivo", se remeta imediatamente ao pretérito imperfeito da língua portuguesa e acredite que esta categoria árabe designa apenas ações ou estados continuados no passado, o que não reflete a realidade completa do $m u d \bar{a} r i^{c}$ árabe.

A configuração das categorias de tempo, aspecto e modo verbal em português é definida de maneira semelhante ao exposto na tradição gramatical árabe. Castilho (2010, p. 418) define o tempo como "uma propriedade da predicação cuja interpretação

\footnotetext{
79 "A Semitic Perfect or Imperfect has, in and of itself, no reference to the temporal relations of the speaker (thinker or writer) and of other actions which are brought into juxtaposition with it. It is precisely these relations which determine in what sphere of time (past, present, or future) a Semitic Perfect or Imperfect lies, and by which of our tenses it is to be expressed - whether by our Past, Perfect, Pluperfect, or Future-perfect; by our Present, Imperfect, or Future."
} 
tem de ser remetida à situação de fala" e afirma que só se pode entender as fatias do tempo (passado, presente, futuro) tomando como referencial o sujeito falante.

Para este mesmo autor, a categoria de aspecto não depende, como o tempo, da postulação de conceitos como o de intervalo e de inserção do ponto primário na linha do tempo, porém, é praticamente impossível descrever o tempo verbal sem considerar o aspecto simultaneamente. Mattoso Câmara (1981, p. 60) define o aspecto verbal como uma:

Propriedade que tem uma forma verbal, de designar a DURAÇÃO do processo (momentâneo ou durativo) ou o aspecto propriamente dito sob que ele é considerado pelo falante (ex.: em seu começo incoativo; em seu curso e ainda inconcluso - imperfeito; em seu fim e já concluso - perfeito; concluso, mas permanente em seus efeitos permansivo). O aspecto coexiste ao lado da categoria de tempo, constituindo com esta um sistema complexo de categorias verbais, em que, conforme a língua, predomina o aspecto ou o tempo ${ }^{80}$.

O modo verbal representa, segundo Câmara (1981, p. 169), a "propriedade que tem a forma verbal de designar a nossa atitude psíquica em face do fato que exprimimos". Na língua portuguesa, há três modos essenciais, a saber, o indicativo em que um fato é assegurado; o subjuntivo ${ }^{81}$ - em que um fato é enunciado com dúvida ou desejo; imperativo - em que um fato é solicitado ou ordenado.

Os conceitos principais que nortearão esta seção podem ser assim resumidos, como expresso na tabela 7 :

Tempo verbal: $\quad$ Categoria que indica se o fato é anterior, simultâneo ou posterior ao momento da enunciação, tendo como referencial o sujeito enunciador.

Aspecto verbal: $\quad$ Categoria que indica "a duração do processo verbal independente da época em que esse processo ocorre." (Azeredo, 2010, p.206)

Modo verbal: $\quad$ Categoria que indica "a atitude ou ponto de vista do enunciador em relação ao objeto de sua comunicação.” (Azeredo, 2010, p. 209)

Tabela 7: Conceitos de tempo, aspecto e modo verbal

\footnotetext{
${ }^{80}$ Mattoso Câmara (1981, p. 60) explica que os tempos latinos se distribuíam em dois grupos o infectum, correspondente ao aspecto imperfectivo, e o perfectum, que correspondia ao aspecto perfectivo. Como o português e as outras línguas românicas descenderam do latim vulgar, não guardaram esse sistema. $\mathrm{O}$ resquício deste agrupamento se manteve na diferenciação entre o pretério perfeito e imperfeito. Outras distinções aspectuais são expressas por meio de construções perifrásticas, como o verbo auxiliar ter conjugado no presente com um particípio passado invariável, que assinala um fato constante contínuo ou repetido (iterativo) até o momento atual.

${ }^{81}$ Também referido por conjuntivo (Câmara, 1981, p. 169).
} 


\section{1 alficl almā $1 \bar{l}^{82}$}

\begin{tabular}{|c|c|c|c|c|c|c|}
\hline \multicolumn{2}{|r|}{ Termo } & \multicolumn{2}{|c|}{$\begin{array}{c}\text { Possível } \\
\text { correspondência } \\
\text { em Pt } \\
\end{array}$} & \multicolumn{2}{|c|}{$\begin{array}{c}\text { Possível } \\
\text { correspondência } \\
\text { em Pt } \\
\end{array}$} & $\begin{array}{c}\text { Proposta de } \\
\text { padronização: }\end{array}$ \\
\hline \multicolumn{2}{|c|}{ ماضٍ mādin } & \multicolumn{2}{|c|}{ Perfectivo } & \multicolumn{2}{|c|}{$\begin{array}{l}\text { Pretérito Perfeito do } \\
\text { indicativo }\end{array}$} & Pretérito Perfeito \\
\hline \multicolumn{2}{|c|}{$\begin{array}{l}\text { DT: } \\
\text { "O que indica um } \\
\text { fato completo e } \\
\text { transcorrido num } \\
\text { tempo anterior } \\
(\ldots), 84\end{array}$} & \multicolumn{2}{|c|}{$\begin{array}{l}\text { DT: } \\
\text { “(...) representa-se } \\
\text { uma ação pontual, } \\
\text { acabada, isto é, uma } \\
\text { ação cujo começo } \\
\text { coincide com seu } \\
\text { desfecho, tornando- } \\
\text { se irrelevantes as } \\
\text { fases de seu } \\
\text { desenvolvimento. } \\
\text { Temos aqui o } \\
\text { aspecto perfectivo } \\
(\ldots) \text { "..) }\end{array}$} & \multicolumn{2}{|c|}{$\begin{array}{l}\text { DT: } \\
\text { "Representa o fato } \\
\text { como concluído e } \\
\text { situa-se } \\
\text { intervalo de tempo } \\
\text { anterior a um ponto } \\
\text { de referência } \\
\text { presente. (...) O } \\
\text { pretérito perfeito é o } \\
\text { tempo característico } \\
\text { da narração de ações } \\
\text { que compõem um } \\
\text { episódio situado em } \\
\text { época anterior ao } \\
\text { momento } \\
\text { enunciação." da }\end{array}$} & $\begin{array}{ll}\text { TL: } & \\
\text { 1. } & \text { Pasado, } \\
& \text { pretérito, } \\
& \text { transcurrido. } \\
& \text { Perfectivo [gr.]. } \\
\text { 2. } & \text { Passado, } \\
& \text { pregresso, } \\
& \text { decorrido. } \\
& \text { Pretérito Gram. }\end{array}$ \\
\hline \multicolumn{2}{|c|}{$\begin{array}{l}\text { EX.: } \\
\text { kataba/ qāma/'akala }\end{array}$} & \multicolumn{2}{|c|}{$\begin{array}{l}\text { Ex.: } \\
\text { encontrei/ absorveu/ } \\
\text { amarraram }\end{array}$} & \multicolumn{2}{|c|}{$\begin{array}{l}\text { Ex.: } \\
\text { morei/ voltaram/ } \\
\text { chegou }\end{array}$} & $\begin{aligned} & \text { Fonte: } \\
& \text { 1. } \text { Corriente, 1991, } \\
& \text { p. } 723 . \\
& \text { 2. } \text { Sabbagh, } 2011, \\
& \text { p. } 585 . \\
&\end{aligned}$ \\
\hline \multicolumn{2}{|c|}{$\begin{array}{l}\text { Fonte: } \\
\text { Alhatīb \& Jaṭal, } \\
1992, \text { p. } 142 .\end{array}$} & \multicolumn{2}{|c|}{$\begin{array}{l}\text { Fonte: } \\
\text { Castilho, 2010, p. } \\
419 .\end{array}$} & \multicolumn{2}{|c|}{$\begin{array}{l}\text { Fonte: } \\
\text { Azeredo, 2010, p. } \\
359 .\end{array}$} & \\
\hline $\mathbf{P t}_{1774}$ & Pretérito & $\mathbf{E s}_{1992}$ & Perfectivo & Voc $_{1908}$ & $\begin{array}{l}\text { Passé } \\
\text { Prétérit }\end{array}$ & \\
\hline $\mathbf{P t}_{2007}$ & Perfectivo & $\mathrm{Fr}_{1911}$ & Parfait & Dic $_{1973}$ & $\begin{array}{l}\text { Past } \\
\text { Preterite }\end{array}$ & \\
\hline $\operatorname{In}_{1862}$ & Perfect & $\operatorname{In}_{1965}$ & Perfect & Dic $_{1983}$ & Past & \\
\hline $\mathbf{I n}_{2005}$ & Past time & & & & & \\
\hline
\end{tabular}

82 Serão considerados apenas os termos dos tempos simples, tanto dos verbos no mā din quanto no $m u d \bar{a} r i^{c}$. Para uma análise mais abrangente sobre a correspondência entre os tempos e aspectos verbais árabes e ingleses, ver Mohammad, 1982, p. 150 - 183.

${ }^{83}$ A palavra mādin é classificada, de acordo com a teoria gramatical árabe, como 'ism manqūṣ. Todos os vocábulos deste grupo possuem a particularidade de receberem um $y \bar{a}$ ' final quando definidas pelo artigo 'al. Quando aparecem indeterminadas, o mesmo yā' não é grafado, seu vestígio, porém, é o duplo kassra (-in) subscrito à última consoante radical. Por esse motivo, apresentam-se duas transliterações, na presente dissertação, para esse termo, uma indeterminada mādin, e outra determinada almā $\bar{l}$.

84 Tradução nossa de: "(...(mā dalla calà hadatin tonammin wamaḍa zamanuhu (...)) 
Na seção anterior, onde foram discutidos os conceitos acerca do tempo, aspecto e modo verbal em ambas as línguas, observou-se que, em árabe, a diferenciação entre tempos verbais não é tão específica e estreita assim como há em português. A teoria gramatical genuína árabe prioriza e distingue os verbos dois aspectos ${ }^{85}$, perfectivo $m a \bar{d}$ din, e imperfectivo - muḍāric. Ao abranger este tema, os gramáticos não árabes optam, no entanto, ou por seguirem a tradição árabe e agruparem os verbos de acordo com os dois aspectos verbais, ou por reelaborarem esta visão e ajustarem os aspectos às diferentes noções de tempo presentes nas suas próprias línguas de chegada.

$\mathrm{Na}$ ficha terminológica acima, observa-se um posicionamento balanceado entre os autores pesquisados quanto à opção para designar o termo mâdin. Dos dez autores citados, cinco deles optaram por reafirmar a visão aspectual do verbo na terminologia adotada, são eles: Cowan (2007), Wright (1862), Corriente (1992), Périer (1911) e Haywood \& Nahmad (1965). Já os outros cinco, o Frei Abrantes (1774), Ryding (2005), Machuel (1908), Cachia (1973) e Bakalla et. al. (1983) inovaram a terminologia quando propuseram termos voltados aos tempos e não aos aspectos verbais. É interessante notar que o panorama equiparado se dá até mesmo nas traduções literais transcritas, em que Corriente sugere a acepção gramatical "perfectivo" e Sabbagh opta por "pretérito", veiculando a noção de tempo.

Verifica-se, contudo, que os gramáticos que optaram pela terminologia aspectual, são incoerentes na descrição dos fatos gramaticais. Embora Wright (1859, p. 46/1862, p. 1), Périer (1911, p. 16), Haywood \& Nahmad (1965, p. 96) e Cowan (2007, p. 63) utilizem uma terminologia que prima pelo aspecto e não pelo tempo verbal, ao iniciarem sua explanação sobre o tema, afirmam que, em árabe, há dois "tempos verbais" e não aspectos. Observa-se o mesmo tratamento em estudos linguísticos recentes, como em Gomes (2011, p. 56), em que o autor explica os "tempos verbais árabes" utilizando uma terminologia aspecto-específico. Apenas Corriente (1992, p. 148) agrega ambas as categorias em uma só, chamando-as de "coordenadas aspectotemporais", dentro das quais tem lugar a predicação das formas verbais.

\footnotetext{
${ }^{85}$ É claro que a tradição clássica gramatical não emprega propriamente o termo "aspecto", contudo a definição terminológica tanto do termo mādin como do mudāric sugere uma noção aspecto-específica e não tempo-específica. Por essa razão, observa-se na literatura não árabe divergências na padronização desta terminologia, uns seguem as proposições árabes clássicas, outros as reinterpretam, aplicando os conceitos da linguística contemporânea.
} 
Considerando-se as definições terminológicas do termo principal māḍin e suas possíveis correspondências em língua portuguesa, verifica-se que há semas presentes na DT árabe que convergem tanto para semas da possível correspondente ${ }_{1}$ quanto da correspondente . $_{\text {. }}$

A DT árabe esclarece que o fato denotado pelo termo mādin é de natureza completa, acabada. Este sema está presente também na definição terminológica do aspecto perfectivo português, que representa uma ação pontual, acabada. O segundo sema relevante é o "fato transcorrido em tempo anterior". Isso quer dizer que o evento se deu completamente em um tempo passado. A definição terminológica do pretérito perfeito do indicativo abarca este sema da mesma forma. Tanto "perfectivo" quanto "pretérito perfeito do indicativo" são termos potenciais na tarefa de designar māḍin em português. Qual seria a melhor escolha para veicular os conceitos árabes originais e ao mesmo tempo ser aparente ao leitor especializado brasileiro?

Acredita-se que empregar o termo pretérito perfeito, omitindo a especificação de modo, seja a melhor para o consulente em questão, pelos seguintes motivos:

1- Trata-se de uma terminologia aparente a qualquer brasileiro escolarizado;

2- Este termo conjuga a categoria tempo passado - pretérito, e a categoria de aspecto concluído - perfeito;

3- Embora haja a distinção de modo verbal em árabe, assim como há em português, māạdin apresenta apenas o modo indicativo, logo não há a necessidade de demonstrar esse traço na terminologia;

4- A definição terminológica do pretérito perfeito (do indicativo) veicula o mesmo conteúdo da DT árabe.

Por isso, na presente dissertação, o termo mādin será designado por pretérito perfeito. 


\section{alficl almud̄âric}

A categoria aspectual árabe mud̄āric designa ações ou estados incompletos, inacabados que ocorrem no tempo simultâneo à situação de fala/escrita ou ocorrerão em um futuro (próximo ou remoto). O muḍāric ${ }^{86}$, sob determinadas condições morfossintáticas, sofre alteração significativa e passa a expressar, por exemplo, passado negativo, futuro, futuro negativo, imperativo, modificando o tempo, o aspecto e/ou o modo verbal. A tradição gramatical divide o mudạric em quatro grupos, a saber,

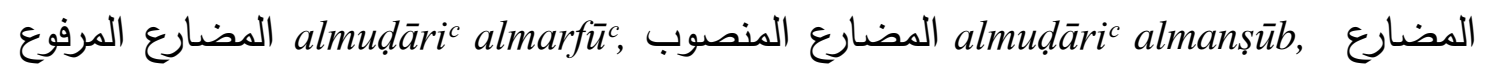
almud̄āric almajzūm, المستقبل المجزوم almustaqbal, cada um destes com uma significação e uso diferenciados.

Nesta seção, todos esses termos serão contemplados e discutidos, porém, antes, julga-se necessário esclarecer o funcionamento de cada termo citado, mecanismo que auxiliará na justificativa da padronização em português.

O árabe é uma língua declinacional, em que há três declinações nominais, a saber, o caso nominativo, acusativo e genitivo. Sintaticamente, chama-se o caso nominativo de $\operatorname{almarf}_{\bar{u}}^{c}$ e este é marcado pelo diacrítico ضَفَّمَ $\operatorname{damma}^{87}$ (-u). O caso acusativo é chamado de almanșūb e marcado pelo diacrítico فَتَحة fatha (-a) ${ }^{88}$. Os verbos almudāaric, da mesma forma que os nomes, recebem os diacríticos ḍamma e fatha além do سُكون sukūn para indicar os três diferentes modos verbais. Assim, o verbo com o diacrítico damma grafado em sua última consoante radical, como em ya'akulu (ele come), será chamado na tradição de almud̄a $r i^{c}$ almarf $\bar{u}^{c}$. O verbo com o diacrítico fatha grafado em sua última radical, como em ya'akula (que ele coma) será chamado de almuḍāric almanșūb.

\footnotetext{
${ }^{86}$ O termo muḍāric, que significa literalmente "semelhante, similar", foi proposto por Sībawayhi (Versteegh, 1997, p. 32) ainda no início da sistematização gramatical árabe, em fins do século VIII. Em seu tratado, Sībawayhi explica que os verbos muḍāric têm as mesmas terminações que os nomes, isto é, o autor sugere a semelhança entre os diacríticos marcadores do modo verbal e os dos casos nominais.

${ }^{87}$ Todo diacrítico marcador dos casos nominais e dos modos verbais estará posicionado na última consoante radical do lexema.

${ }^{88}$ Wright (1859, p. 58) afirma, em nota, que o damma e o fatha do imperfectivo indicativo e do subjuntivo correspondem ao damma e ao fatha dos casos nominais nominativo e acusativo, o que corrobora a proposição de Sībawayhi quanto à semelhança entre os verbos muḍāric e os nomes declinados.
} 
Semanticamente, o verbo almuḍāric $\operatorname{almarf}^{c}$ designa ações incompletas no momento da enunciação ou que estão em curso e se completarão posteriormente. Convencionou-se considerar este como o modo indicativo de ações ou estados expressos pelo verbo, uma vez que o enunciador assegura o fato narrado.

Quando a forma verbal almudāari ${ }^{c}$ almarfī $\bar{u}^{c}$ for antecedida pelas partículas

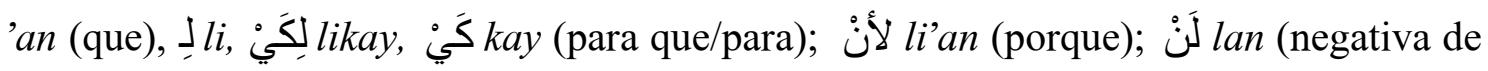
futuro); إذَنْ 'idan (então), haverá a mudança do diacrítico final de damma (-u) para fatha (-a), assim como do ponto de vista do enunciador frente ao fato narrado, isto é, ocorre uma alteração do modo verbal, passando para o subjuntivo, chamado em árabe de almuḍaric almanșūb, modo que expressa a dúvida ou o desejo frente a um fato ou estado citado.

Contrário ao que se possa imaginar, a forma verbal almuḍāric almajzūm não representa, sintaticamente, o caso genitivo ${ }^{89}$. O termo $\mathrm{jazm}^{90}$, que significa "apócope, avocálico, sem acento $^{91,}$ em árabe, refere-se à ausência da vogal breve final na última radical dos verbos. A ausência do marcador modal, ou seja, do damma (-u) e do fatha (a), é representada graficamente pelo sukūn.

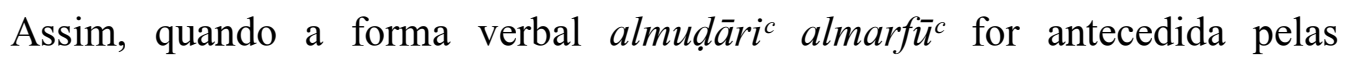

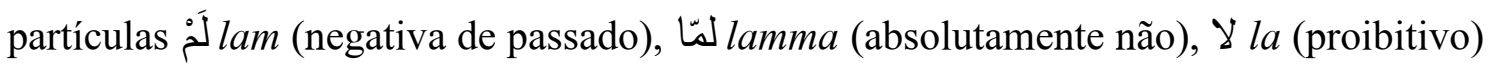
ou $J i^{92}$ (jussivo ou exortativo) a vogal marcadora final damma (-u) é substituída pelo sukūn, passando a ser chamada de almuḍāric almajzūm. Corriente (1992, p. 158) afirma que, morfologicamente, esta forma verbal é mais simples do que as outras duas mencionadas anteriormente e que a ela falta um conteúdo semântico-sintático uniforme, pois, ao ser sempre requerida após uma das partículas supracitadas, ora designa negação, seja do passado ou da situação atual, ora indica uma mudança do modo verbal indicativo para o imperativo.

\footnotetext{
${ }^{89} \mathrm{O}$ caso genitivo é designado pelo termo almajrūr e representado sintaticamente pelo kasra (-i).

${ }^{90}$ Termo principal de onde se deriva o termo almajzum, que significa "o apocopado".

${ }^{91}$ Sabbagh, 2010, p. 232.

${ }^{92}$ Quando a partícula $l i$ for antecedida pelas conjunções $w a$ (e) e $f a$ (então, e) costuma perder sua vogal breve (-i), como, por exemplo, li-yaktub $>$ fal-yaktub. Esta conjugação com tais usos é frequente com a $3^{\text {a }}$ pessoa, raro com a $1^{\mathrm{a}}$ p. e raríssimo com a $2^{\mathrm{a}}$ p. no lugar do imperativo. (Corriente, 1992, p. 158)
} 
A última variação da forma verbal almuḍa $\operatorname{ric}^{c} \operatorname{almarf}^{c}$ ocorre quando a ela for antecedida a partícula سَوف sawfa ou o prefixo wَ, como em sawfa yaktubu ou sayaktubu (ele escreverá). Note que não há alteração no marcador (-u) da última radical do verbo, que indica o modo verbal indicativo. O que importa, neste caso, são os morfemas $[s a w f a]$ e $[s a-]$ indicadores do tempo futuro remoto e imediato, respectivamente, e que são antepostos ao verbo almuḍāric $\operatorname{almarfiu}^{c}$, passando a ser chamados pela teoria gramatical de almustaqbal. 


\section{1 almuḍāric almarfǘc}

\begin{tabular}{|c|c|c|c|c|c|c|c|}
\hline \multicolumn{2}{|c|}{ Termo } & \multicolumn{2}{|c|}{$\begin{array}{c}\text { Possível } \\
\text { correspondência } \\
\text { em Pt }\end{array}$} & \multicolumn{2}{|c|}{$\begin{array}{c}\text { Possível } \\
\text { correspondência } \\
\text { em Pt }\end{array}$} & $\begin{array}{c}\text { Possível } \\
\text { correspondência } \\
\text { em Pt } \\
\end{array}$ & $\begin{array}{c}\text { Proposta de } \\
\text { padronização: }\end{array}$ \\
\hline \multicolumn{2}{|c|}{ 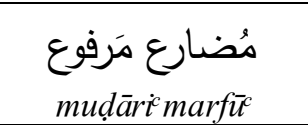 } & \multicolumn{2}{|c|}{ Imperfectivo } & \multicolumn{2}{|c|}{$\begin{array}{c}\text { Presente do } \\
\text { indicativo }\end{array}$} & $\begin{array}{c}\text { Futuro do } \\
\text { presente do } \\
\text { indicativo }\end{array}$ & $\begin{array}{l}\text { Presente do } \\
\text { indicativo }\end{array}$ \\
\hline \multicolumn{2}{|c|}{$\begin{array}{l}\text { DT: } \\
\text { "O que indica um } \\
\text { fato incompleto que } \\
\text { ocorre no tempo } \\
\text { atual ou ocorrerá no } \\
\text { futuro }(. . .) . " 93\end{array}$} & \multicolumn{2}{|c|}{$\begin{array}{l}\text { DT: } \\
\text { “(...) representa uma } \\
\text { predicação que tem } \\
\text { existência tão logo } \\
\text { iniciada, } \\
\text { dispensando seu } \\
\text { desfecho (...)." }\end{array}$} & \multicolumn{2}{|c|}{$\begin{array}{l}\text { DT: } \\
\text { "Representa o fato } \\
\text { como não } \\
\text { concluído, } \\
\text { situando-o num } \\
\text { intervalo de tempo } \\
\text { do qual faz parte o } \\
\text { próprio momento } \\
\text { da enunciação." }\end{array}$} & $\begin{array}{l}\text { DT: } \\
\text { "Representa } \\
\text { fato como não } \\
\text { concluído e o } \\
\text { situa num } \\
\text { intervalo de } \\
\text { tempo posterior } \\
\text { ao presente (...) } \\
\text { ou simultâneo ao } \\
\text { momento da } \\
\text { enunciação (...)." }\end{array}$ & $\begin{array}{l}\text { TL: } \\
\begin{array}{ll}\text { 1. } & \text { a. } \\
& \text { Semejante } \\
& \text {, similar. } \\
& \text { Imperfecti } \\
& \text { vo [gr.]. } \\
& \text { b. } \\
& \text { Indicativo } \\
& \cdot \\
\text { 2. } & \text { a. } \\
& \text { Presente } \\
& \text { (verbo). b. } \\
& \text { Do sujeito } \\
\text { Gram. }\end{array}\end{array}$ \\
\hline \multicolumn{2}{|c|}{$\begin{array}{l}\text { EX.: } \\
\text { yaktubu/yaqūmu/ } \\
\text { ya'kulu }\end{array}$} & \multicolumn{2}{|c|}{$\begin{array}{l}\text { Ex.: } \\
\text { arruma/ } \\
\text { vivem dizendo/ } \\
\text { pôs-se a cantar/ } \\
\text { absorvia }\end{array}$} & \multicolumn{2}{|c|}{$\begin{array}{l}\text { Ex.: } \\
\text { moramos/ volta/ } \\
\text { vendo }\end{array}$} & $\begin{array}{l}\text { Ex.: } \\
\text { saberão/ } \\
\text { pagaremos/ estará }\end{array}$ & $\begin{array}{l}\text { Fonte: } \\
\text { 1. Corriente, } \\
\text { 1991, p. } \\
458 / 303 . \\
\\
\text { 2. Sabbagh, } \\
2011, \mathrm{p} . \\
649 / 628 .\end{array}$ \\
\hline \multicolumn{2}{|c|}{$\begin{array}{l}\text { Fonte: } \\
\text { Alhatīb \& Jațal, } \\
\text { 1992, p. } 142 .\end{array}$} & \multicolumn{2}{|c|}{$\begin{array}{l}\text { Fonte: } \\
\text { Castilho, 2010, p. } \\
419 .\end{array}$} & \multicolumn{2}{|c|}{$\begin{array}{l}\text { Fonte: } \\
\text { Azeredo, 2010, p. } \\
358 \text {. }\end{array}$} & $\begin{array}{l}\text { Fonte: } \\
\text { Azeredo, 2010, p. } \\
361 .\end{array}$ & \\
\hline $\mathbf{P t}_{1774}$ & Futuro & $\mathbf{E s}_{1992}$ & $\begin{array}{l}\text { Imperfectivo } \\
\text { indicativo }\end{array}$ & Voc $_{1908}$ & $\begin{array}{l}\text { Aoriste }^{94} \\
\text { indicatif }\end{array}$ & & \\
\hline $\mathbf{P t}_{2007}$ & $\begin{array}{l}\text { Imperfectivo } \\
\text { Indicativo } \\
\text { simples }\end{array}$ & $\mathbf{F r}_{1911}$ & Imparfait & Dic $_{1973}$ & $\begin{array}{l}\text { Aorist } \\
\text { Imperfect }\end{array}$ & & \\
\hline $\operatorname{In}_{1859}$ & $\begin{array}{l}\text { Imperfect } \\
\text { indicative }\end{array}$ & $\operatorname{In}_{1965}$ & $\begin{array}{l}\text { Imperfect } \\
\text { indicative }\end{array}$ & Dic $_{1983}$ & Present & & \\
\hline $\mathbf{I n}_{2005}$ & $\begin{array}{l}\text { Present } \\
\text { tense }\end{array}$ & & & & & & \\
\hline
\end{tabular}

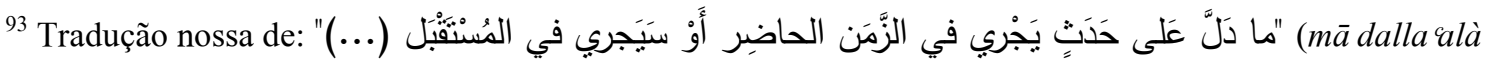
alhadați yajrī fì az-zamani alhāọdiri 'aw sayajī fì almustaqbali (...) )

94 "Forma aspectual e temporal do verbo grego antigo, que preservava a ação pura, sem determinação quanto à duração do processo ou ação ou ao seu acabamento." (Houaiss, 2007) 
A definição terminológica árabe do termo $m u d \operatorname{ạ} i^{c}{ }^{c}$ é a mesma do termo muḍāric ${ }^{c}$ $\operatorname{marf} \bar{u}^{c}$, pois se considera este último a forma base para as alterações modais e temporais advindas da anteposição de partículas ou prefixos.

Observa-se que na DT árabe há três semas principais, a) "fato incompleto, inacabado"; b) “ocorre no tempo contemporâneo"; c) "ocorrerá no futuro". Estes semas representam três ideias diferenciadas em português. Um fato ainda não concluído indica, na gramática portuguesa, o aspecto imperfectivo, que pode referir-se ao tempo passado - o pretérito imperfeito, por exemplo - ao tempo presente e ao tempo futuro. $\mathrm{O}$ segundo sema designa uma ação que ocorre (ou está em curso) no mesmo intervalo de tempo da enunciação, isto é o presente do indicativo português. O terceiro sema referese a uma ação futura, posterior à situação de fala/escrita, tem-se aí o futuro do presente indicativo. Como proceder mediante três correspondentes potenciais em português para designar um único termo árabe?

Da mesma forma como o termo mādin, analisado em 2.1, os autores pesquisados dividem-se entre uma terminologia que expresse o conceito aspectual ou o temporal. O panorama é, contudo, menos equilibrado. Dentre os termos apresentados, apenas $30 \%$ dos autores sugere que muḍa $r^{c} i^{c}$ represente o conceito temporal e mesmo assim as propostas não são homogêneas.

Apesar de os gramáticos abordados descreverem o funcionamento desta categoria verbal como o tempo, a maioria dos autores propõe uma terminologia voltada ao aspecto do verbo. Machuel (1908) e Cachia (1973) propuseram "aoristo" para designar o muḍāric $\operatorname{marf}_{\bar{u}}^{c}$ árabe, termo pertencente à gramática grega antiga que possui o conveniente de expressar em um único lexema a forma aspectual e temporal do verbo grego, porém, esta terminologia grega é distante da realidade gramatical portuguesa como também opaca aos consulentes brasileiros.

Frei Abrantes (1774, p. 125) é o único arabista dentre os citados a lançar mão do termo "futuro" a fim de indicar a forma verbal muḍaric $m a r f \bar{u}^{c}$, reiterando a tendência bipartida do tempo semítico, citada em Lipiński (1997, p. 332). O gramático português afirma que o termo "futuro" compreende o presente e o futuro do indicativo, prevenindo que para isto é preciso que os morfemas [sawfa] e [sa-] antecedam ao verbo. Isto quer dizer que a acepção de futuro está estritamente ligada aos morfemas citados e não à forma verbal independente. Considera-se uma opção inadequada aos leitores lusófonos, pois o termo principal $m u d \bar{a} r i^{c} \operatorname{marfu}^{c}$ apenas indicará o futuro se a ressalva acima for atendida. 
Verificou-se que, mesmo os gramáticos que sugeriram a terminologia aspectual, consideraram sua tradução como presente (ou futuro, se precedido pelos morfemas citados) em suas línguas de chegada. Haywood \& Nahmad (1965, p. 110), por exemplo, propõem o termo imperfective indicative, termo aspecto-modal, em seguida afirmam que este é mais frequentemente traduzido em inglês por presente e futuro. Périer (1911, p. 16), da mesma forma, atesta que o imparfait indica o presente e o futuro em francês.

Como ficou acordado acima, optou-se nesta dissertação por propor a terminologia dos verbos árabes de acordo com as relações de tempo, por considerá-la mais pragmática e aparente ao leitor especializado brasileiro, como também se trata de uma tentativa de evitar mal-entendidos conceituais que possam ser divergentes em árabe e português.

Desta forma, descarta-se o primeiro possível correspondente - "imperfectivo", por considerar que os semas comuns existentes entre os termos "imperfectivo" e muḍaric $\operatorname{marf}^{c} \bar{u}^{c}$, imprescindíveis para a real compreensão do assunto, serão expostos e esclarecidos na medida em que o estudante aprofunde-se neste tema.

A terceira possível correspondência - "futuro do presente indicativo" também não representa um termo adequado em português, porque pode confundir o leitor/estudante, veiculando a ideia de que o muḍāric marf $\bar{u}^{c}$ designe estritamente o futuro, uma inverdade, uma vez que a acepção futura está atrelada à anteposição dos morfemas $[s a w f a]$ e [sa-]. A teoria gramatical árabe moderna chama de mustaqbal a significação futura do $m u d \underline{a} \bar{a} i^{c} \operatorname{marf} \bar{u}^{c}$.

Sugere-se, então, que o presente do indicativo seja empregado na tarefa de designar o termo árabe muḍāric marfüc . Acredita-se que a proposta expresse os semas principais da DT árabe, a saber, "fato incompleto, inacabado" e "ocorre no tempo contemporâneo (ao momento da enunciação)", já que a acepção futura é representada por outro termo e será tratada na seção 4 . 


\section{2 almuḍāric almanșūb}

\begin{tabular}{|c|c|c|c|c|c|}
\hline & Termo & \multicolumn{2}{|c|}{$\begin{array}{c}\text { Possível correspondência } \\
\text { em } \mathrm{Pt}\end{array}$} & \multicolumn{2}{|c|}{ Proposta de padronização } \\
\hline \multicolumn{2}{|c|}{$\begin{array}{l}\text { مُضارع مَنْصوبْ } \\
\text { mud̄āric manșūb }\end{array}$} & \multicolumn{2}{|c|}{ Presente do subjuntivo } & \multicolumn{2}{|r|}{ Subjuntivo } \\
\hline \multicolumn{2}{|c|}{ 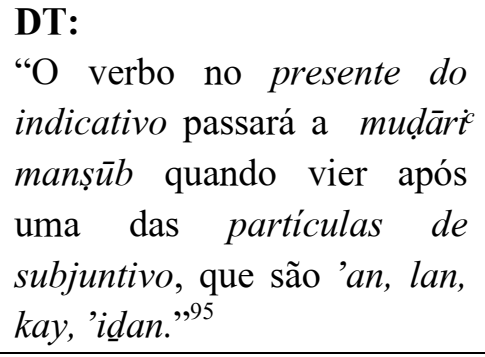 } & \multicolumn{2}{|c|}{$\begin{array}{l}\text { DT: } \\
\text { "Representando o fato como } \\
\text { não concluído, situa-o num } \\
\text { intervalo de tempo } \\
\text { simultâneo ou posterior ao } \\
\text { presente." }\end{array}$} & \multicolumn{2}{|c|}{$\begin{array}{ll}\text { TL: } & \\
\text { 1. } & \text { a. Semejante, similar. } \\
& \text { Imperfectivo [gr.].b. En } \\
& \text { acusativo. Subjuntivo. } \\
\text { 2. } & \text { a. Presente (verbo). b. } \\
& \text { Acusativo. Modo } \\
& \text { conjuntivo } 96\end{array}$} \\
\hline \multicolumn{2}{|c|}{$\begin{array}{l}\text { Ex.: } \\
\text { an yaktuba/ lan yaktuba/ } \\
\text { kay yaktuba }\end{array}$} & \multicolumn{2}{|c|}{$\begin{array}{l}\text { Ex.: } \\
\text { Acretido que eles conheçam } \\
\text { os donos da casa. } \\
\text { Ela quer que nós a } \\
\text { acompanhemos. }\end{array}$} & \multicolumn{2}{|c|}{$\begin{aligned} \text { Fonte: } & \\
\text { 1. } & \text { Corriente, 1991, p. } 458 / \\
& 763 . \\
\text { 2. } & \text { Sabbagh, 2011, 649/ } \\
& 689 .\end{aligned}$} \\
\hline \multicolumn{2}{|c|}{$\begin{array}{l}\text { Fonte: } \\
\text { Alhatīib \& Jațal, 1992, p. } 145 .\end{array}$} & \multicolumn{2}{|c|}{$\begin{array}{l}\text { Fonte: } \\
\text { Azeredo, 2010, p. } 364 .\end{array}$} & & \\
\hline $\mathbf{P t}_{1774}$ & $\begin{array}{l}\text { Subjuntivo } \\
\text { Antithesis }\end{array}$ & $\mathbf{E s}_{1992}$ & $\begin{array}{l}\text { Imperfectivo } \\
\text { subjuntivo }\end{array}$ & Voc $_{1908}$ & Subjontif [verbe] \\
\hline $\mathbf{P t}_{\mathbf{2 0 0 7}}$ & Modo subjuntivo & $\mathbf{F r}_{1911}$ & Subjonctif & Dic $_{1973}$ & Subjunctive \\
\hline $\mathbf{I n}_{1859}$ & Subjuntive & $\operatorname{In}_{1965}$ & $\begin{array}{l}\text { Imperfect } \\
\text { subjunctive }\end{array}$ & Dic $_{1983}$ & Subjunctive mood \\
\hline $\mathbf{I n}_{2005}$ & Subjuntive & & & & \\
\hline
\end{tabular}

Ao observar a ficha terminológica acima, verifica-se que o termo árabe muḍāric manșūb possui uma abordagem já padronizada nas línguas em foco, pois todas consideram-no como a forma correspondente ao modo subjuntivo do verbo, no entanto, se as definições terminológicas forem levadas em conta, pode-se afirmar que não há semas aparentes em comum.

$\mathrm{O}$ aprofundamento no assunto tanto em árabe quanto em português, por sua vez, permite reconhecer características comuns que justifiquem a padronização do termo subjuntivo. Corriente (1992, p. 157) afirma que:

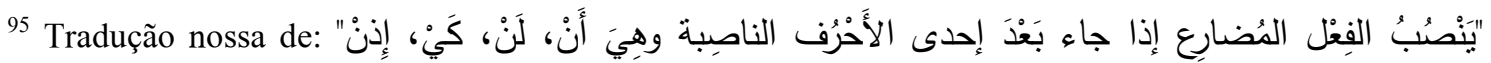
(yanșubu alfit almud̄āric 'idā jā' bacda 'ihdà al'alhruf an-nāṣiba wa hiya 'an, lan, kay, 'id̄an.)

96 "O Subjuntivo ou CONJUNTIVO é o modo verbal destinado desde o indo-europeu a assinalar que o processo é apenas admitido em nosso espírito e, portanto, passível de dúvida, em oposição ao indicativo." (Câmara, 1981, p. 225)
} 
No aspecto imperfectivo, o verbo árabe distingue três modos, cujo uso depende em uns casos de conotações semântico-sintáticas (como o caráter da oração subordinada ou independente, o que respectivamente pode exigir a seleção do subjuntivo ou indicativo $(\ldots)^{97}$-(Tradução e grifos nossos)

O fato de a oração subordinada exigir a seleção do chamado modo subjuntivo árabe - muḍāric manșūb, é comum ao que acontece em português, como atestado por Bechara (1999, p. 280), uma vez que "modo subjuntivo ocorre normalmente (...) nas orações subordinadas em que o fato é considerado como incerto, duvidoso ou impossível de se realizar".

Como em português, o que determina a subordinação é a presença de conjunções subordinativas que conectarão as duas orações. Em árabe, o mesmo processo se dá, pois quando uma das partículas 'an (que), likay, kay, li (para que/para), li'an (porque), 'idan ${ }^{98}$ (então) antecede o verbo no presente do indicativo (termo proposto nesta dissertação), funcionará como conector entre as duas orações, como em:

(5) 'uridu 'an 'usāfira 'ilà aš-šarqi al'awsați.

Quero viajar para o Oriente Médio. (= quero que eu viaje)

(6) waṣlat almudarrisatu 'ilà almadrasati likay tudarrisa țulābiha.

A professora chegou à escola para que ensine a seus alunos.

A máxima acima apenas não se aplica à partícula lan, porque não funciona como partícula subordinativa, por não conectar orações. Esta inicia as sentenças, imprime ao verbo a conotação negativa e transfere sua significação do presente indicativo para o futuro. Cowan (2007, p. 99) explica que a estrutura profunda da partícula lan é uma contração de la yakūna 'an ("não é possível que seja"), o que justifica a inclusão desta partícula no grupo das subordinativas.

\footnotetext{
97 "En el aspecto imperfectivo, el verbo árabe distingue tres modos, cuyo uso depende en unos casos de connotaciones semántico-sintácticas (como el carácter de la oración de subordinada o independiente, lo que respectivamente puede exigir la selección de subjuntivo o indicativo) (...)"

${ }^{98}$ Há na literatura outras partículas subordinativas possíveis, as citadas são pois as mais frequentes.
} 
A marca sintática do modo subjuntivo árabe consiste na alteração do marcador de modo da última radical - o damma indicativo passa a fatha subjuntivo ${ }^{99}$, assim como ilustrado abaixo:

(7) 'usāfiru 'ilà aš-šarqi al'awsați bacd šahraini.

Viajo para o Oriente Médio em dois meses. (modo indicativo)

(8) lan 'usâfira 'ilà aš-šarqi al'awsați.

Não viajarei para o Oriente Médio. (modo subjuntivo)

Preferiu-se apenas o termo subjuntivo ao presente do subjuntivo a fim de padronizar em português o termo mudāaric manșūb, devido à acepção de futuro negativo decorrente da partícula lan.

\footnotetext{
${ }^{99}$ Há cinco formas verbais do presente do indicativo que não possuem o damma final indicativo, pois carregam em si além dos prefixos, sufixos indicadores da pessoa do discurso a que pertencem. São elas a $2^{\mathrm{a}} \mathrm{p}$ fem. sing., $2^{\mathrm{a}}$ e $3^{\mathrm{a}} \mathrm{p}$ dual sing. e $2^{\mathrm{a}}$ e $3^{\mathrm{a}} \mathrm{p}$ masc. pl. Quando a estas formas verbais forem antecedidas as partículas do subjuntivo ou as do modo apocopado (que será visto em seguida), haverá a apócope do $n \bar{u} n$ sufixal. Estas cinco formas verbais são chamadas na teoria árabe de al'af'al alhamsa.
} 


\section{almud̄āric almajzūm}

\begin{tabular}{|c|c|c|c|c|c|}
\hline & Termo & Possí & $\begin{array}{l}\text { el correspondência } \\
\text { em Pt }\end{array}$ & Propo & sta de padronização \\
\hline & مُضَارع مَجْزْه & & Imperativo & & Apocopado \\
\hline $\begin{array}{l}\text { DT: } \\
\text { "O ver } \\
\text { indicati } \\
\text { majzūm } \\
\text { uma d } \\
\text { regem e } \\
\text { lam, lan } \\
\text { la (proib }\end{array}$ & $\begin{array}{l}\text { o no presente do } \\
\text { passará a mud̄arit } \\
\text { quando vier após } \\
\text { s partículas que } \\
\text { ta forma, são elas: } \\
\text { ma, li (imperativo), } \\
\text { tivo). }{ }^{100,}\end{array}$ & $\begin{array}{l}\text { DT: } \\
\text { “(...) o } \\
\text { se usa } \\
\text { enuncia } \\
\text { ordem, } \\
\text { pedido. }\end{array}$ & $\begin{array}{l}\text { modo imperativo (...) } \\
\text { em frases com que o } \\
\text { dor expressa uma } \\
\text { uma exortação, um }\end{array}$ & $\begin{array}{l}\text { TL: } \\
1 . \\
2 . \\
\end{array}$ & $\begin{array}{l}\text { Semejante, similar. } \\
\text { mperfectivo [gr.].b. } \\
\text { Cortado. Marcado con } \\
\text { azm. Apocopado. } \\
\text { Presente (verbo). b. } \\
\text { apocopado (verbo no } \\
\text { mperativo ou no } \\
\text { assado negativo). }\end{array}$ \\
\hline $\begin{array}{l}\text { Ex.: } \\
\text { lam yakt } \\
\text { ya'kul }\end{array}$ & b/ liyaqūm/lamma & $\begin{array}{l}\text { Ex.: } \\
\text { "Acord } \\
\text { e ajud } \\
\text { mão d } \\
\text { coisas 1 }\end{array}$ & $\begin{array}{l}\text { a, meu bem, acorda/ } \\
\text { o teu madrugar/ a } \\
\text { dia transborda/ de } \\
\text { ara te dar" }\end{array}$ & $\begin{array}{c}\text { Fonte: } \\
1 . \\
2 .\end{array}$ & $\begin{array}{l}\text { Corriente, 1991, p. } 458 / \\
12 . \\
\text { abbagh, 2011, p. } 649 / \\
06 .\end{array}$ \\
\hline $\begin{array}{l}\text { Fonte: } \\
\text { Alhatîib }\end{array}$ & Jațal, 1992, p. 148. & $\begin{array}{l}\text { Fonte: } \\
\text { Azered }\end{array}$ & 2010, p. 210 & & \\
\hline $\mathbf{P t}_{1774}$ & Apócope & $\mathbf{E s}_{1992}$ & $\begin{array}{l}\text { Imperfectivo } \\
\text { apocopado }\end{array}$ & Voc $_{1908}$ & $\begin{array}{l}\text { Conditionnel } \\
\text { Aoriste apocopé }\end{array}$ \\
\hline $\mathbf{P t}_{2007}$ & Modo jussivo & $\operatorname{Fr}_{1911}$ & Conditionnel & Dic $_{1973}$ & $\begin{array}{l}\text { Apocopate } \\
\text { Jussive }\end{array}$ \\
\hline $\mathbf{I n}_{1859}$ & Jussive & $\operatorname{In}_{1965}$ & Imperfect jussive & Dic $_{1983}$ & Jussive mood \\
\hline $\mathbf{I n}_{2005}$ & Jussive & & & & \\
\hline
\end{tabular}

Considerando as definições terminológicas do termo árabe muḍāric majzūm e do termo português "imperativo" há apenas um sema que sugere alguma identidade entre ambas, trata-se da acepção de imperativo determinada pela anteposição da partícula $l i$ ao verbo no presente do indicativo. Pode-se dizer que o la (proibitivo) também tangencie a significação imperativa, pois uma vez que se proíbe algo, ordena-se que tal ação não seja executada.

Três termos foram os escolhidos pelos autores em questão na tarefa de designar o termo árabe muḍāic majzūm, são eles "apócope/apocopado", “jussivo" e "condicional".

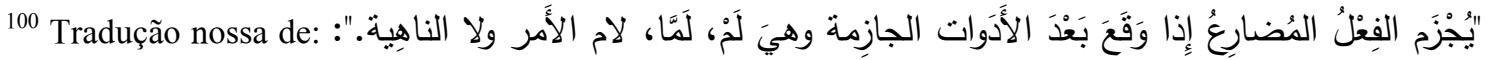
(yujzam alfit almuḍārí 'idāa waqáa bacda al'adawāt aljāzima wa hiya lam, lamma, lām al'amr wa lā annāhiya.)
} 
O termo "condicional” traduz um uso raro da forma muḍāric majzūm que são as construções condicionais. Segundo Cowan (2007, p. 103), o mud̄āric majzūm ou o pretérito perfeito será antecedido pelas partículas 'in ou 'iḍa, constituindo uma condição que pode ser cumprida:

(9) 'in taḍib tuḍrab. (muḍāric majzūm)/ 'in darabta duribta. (pretérito perfeito)

Se golpeares, serás golpeado.

O termo "jussivo" está registrado no Dicionário Eletrônico Houaiss da Língua Portuguesa (2007) como "relativo ao modo imperativo". Relaciona-se aos usos do muḍāric majzūm, após as partículas $l i$ e la, indicando ordem/pedido e proibição, respectivamente. Os gramáticos árabes afirmam que esta é uma maneira mais educada para se ordenar ou pedir algo.

O termo "apocopado" refere-se não ao traço semântico deste modo, e sim à morfologia do marcador modal nos verbos. Quando um verbo no presente do indicativo, cuja marca modal é o damma, for antecedido pelas partículas lam, lamma, li, la, este marcador modal sofrerá apócope ${ }^{101}$ e será substituído pelo diacrítico árabe $s u k \bar{u} n$, que indica ausência de um fonema vocálico. As pessoas do discurso, cuja última radical não termina em damma, impossibilitando a substituição pelo sukūn, seguirão o descrito na nota 100 .

Segundo Cowan (2007, p. 104), o uso mais frequente do modo muḍāric majzūm ocorre quando esta forma é antecedida pelas partículas lam e lamma. A primeira nega o verbo e leva sua significação para o pretérito perfeito e a segunda equivale a "ainda ... não" ou "não ... ainda".

(10) lam 'afham kalāmahu.

Não entendi as palavras dele.

(11) lamma yafham macnà hadihi alkalimati.

Ele ainda não compreendeu o significado desta palavra.

101 “Desaparecimento de um fonema em fim de vocábulo.” (Câmara, 1981, p. 57) 
Assim, propõe-se que seja adotado, em português, o termo apocopado para designar o modo verbal árabe muḍāric majzūm, porque:

1) o termo "condicional" é pouco usado, não refletindo todas as possibilidades do modo verbal árabe;

2) o termo "jussivo" limita-se ao uso imperativo deste modo, excluindo seu uso mais frequente;

3) o termo "apocopado" reflete a característica principal dos verbos muḍāric majzūm, isto é, ter sua vogal marcadora do modo apocopada e substituída pelo sukūn.

O termo apocopado pode até não ser um termo totalmente aparente ao leitor brasileiro distante dos estudos linguísticos, contudo, o fenômeno fonético da apócope está presente na gramática portuguesa e, por isso, registrado nos melhores dicionários de língua comum existentes hoje em dia. 


\section{4 -almustaqbal}

\begin{tabular}{|c|c|c|c|c|c|}
\hline & Termo & \multicolumn{2}{|c|}{$\begin{array}{c}\text { Possível correspondência } \\
\text { em Pt }\end{array}$} & \multicolumn{2}{|c|}{ Proposta de padronização } \\
\hline \multicolumn{2}{|c|}{ مُسْتَقْبْلَ mustaqbal } & \multicolumn{2}{|c|}{ Futuro do presente } & & Futuro \\
\hline \multicolumn{2}{|c|}{$\begin{array}{l}\text { DT: } \\
\text { "O tempo futuro é formado } \\
\text { pela prefixação ou do } \\
\text { morfema } s a-\text { ou da partícula } \\
\text { sawfa ao verbo no tempo } \\
\text { presente do indicativo. }{ }^{102, "}\end{array}$} & \multicolumn{2}{|c|}{$\begin{array}{l}\text { DT: } \\
\text { "Representa o fato como não } \\
\text { concluído e o situa num } \\
\text { intervalo de tempo posterior } \\
\text { ao presente (...) ou } \\
\text { simultâneo ao momento da } \\
\text { enunciação (...)". }\end{array}$} & \multicolumn{2}{|c|}{$\begin{array}{ll}\text { TL: } & \\
\text { 1. } & \text { The future. } \\
\text { 2. } & \text { Futuro, porvindouro. }\end{array}$} \\
\hline \multicolumn{2}{|c|}{$\begin{array}{l}\text { Ex.: } \\
\text { sayaktubu/ sawfa yaqūmu/ } \\
\text { saya'kulu }\end{array}$} & \multicolumn{2}{|c|}{$\begin{array}{l}\text { Ex.: } \\
\text { saberão/ pagaremos/ estará }\end{array}$} & \multicolumn{2}{|c|}{$\begin{array}{l}\text { Fonte: } \\
\text { 1. Wehr, 1976, p. } 742 . \\
\text { 2. } \\
\text { Sabbagh, 2011, p. } 636 .\end{array}$} \\
\hline \multicolumn{2}{|c|}{$\begin{array}{l}\text { Fonte: } \\
\text { Ryding, } 2005, \text { p. } 442 .{ }^{103}\end{array}$} & \multicolumn{2}{|c|}{$\begin{array}{l}\text { Fonte: } \\
\text { Azeredo, 2010, p. } 361 .\end{array}$} & & \\
\hline $\mathbf{P t}_{1774}$ & Futuro & $\mathbf{E s}_{1992}$ & Futuro & Voc $_{1908}$ & Futur \\
\hline $\mathbf{P t}_{2007}$ & Futuro & $\mathbf{F r}_{1911}$ & Futur & Dic $_{1973}$ & Future \\
\hline $\mathbf{I n}_{1859}$ & Future & $\operatorname{In}_{1965}$ & Future & Dic $_{1983}$ & Future \\
\hline$I_{2005}$ & Future tense & & & & \\
\hline
\end{tabular}

O que indica um fato incompleto que ocorre no tempo contemporâneo ou ocorrerá no futuro, chama-se de alficl almudạrici. (Alhatīi \& Jațal, 1992, p.142) - (Nossa tradução)

De acordo com a citação acima, verifica-se que tanto o presente do indicativo quanto o futuro pertencem ao aspecto imperfectivo árabe, informação determinante para a aproximação de ambas as definições terminológicas, que, a princípio, não compartilham nenhum sema.

De fato, o tempo futuro árabe deriva-se do presente, isto é, todas as formas verbais de ambos os tempos flexionam-se igualmente, a particularidade do futuro está na anteposição da partícula sawfa ou do prefixo $s a^{104}$ ao verbo. Semanticamente, há uma diferença entre esses dois morfemas, a partícula sawfa indica um futuro mais

\footnotetext{
102 Tradução nossa de: "The future is formed by prefixing either the morfeme sa- or the particle sawfa to the presente tense indicative verb."

103 Não foi verificada uma definição terminológica para o termo mustaqbal nos manuais árabe-árabes consultados, uma vez que o mesmo deriva-se do verbo mud̄aric marfūu. Por isso, citou-se aqui uma definição retirada de uma gramática árabe em língua inglesa.

${ }^{104}$ Os morfemas [sawfa] e [sa-] são denominados na tradição árabe pelo termo harf al'istqbāl ou, literalmente, "partícula da espera".
} 
distante, mais remoto, enquanto o prefixo $s a$ - refere-se ao futuro imediato. (El-Daḥdāḥ, 1997, p. 172)

Embora os gramáticos estudados não compartilhem da mesma visão quanto à descrição dos verbos segundo a noção aspectual ou temporal, como visto acima, todos concordam com o termo "futuro" para designar o termo árabe mustaqbal.

Assim, sugere-se que seja seguida a tendência dos autores pesquisados e adotese o termo futuro a fim de expressar, em português, o termo árabe mustaqbal.

Considerando que a gramática portuguesa abarca diferentes nuances de tempo (pretérito, presente e futuro) para os modos indicativo e subjuntivo, e que, diferentemente, os modos subjuntivo e apocopado árabes não disponham de tantas variações temporais, não se verifica a necessidade de manter o sintagma adjetival "do presente" após o termo "futuro".

\section{4. فِعْل الأَّْْر - ficl al'amr}

\begin{tabular}{|c|c|c|c|c|c|}
\hline & Termo & Possí & $\begin{array}{l}\text { el correspondência } \\
\text { em Pt }\end{array}$ & Propo & ta de padronização \\
\hline ficl al' & فِعْل الأََْ & & Imperativo & & Imperativo \\
\hline $\begin{array}{l}\text { DT: } \\
\text { "O que i } \\
\text { acontece } \\
\text { se fil al"c }\end{array}$ & $\begin{array}{l}\text { dica um pedido que } \\
\text { á no futuro chama- } \\
m r^{105,}\end{array}$ & $\begin{array}{l}\text { DT: } \\
\text { “(...) o } \\
\text { se usa } \\
\text { enuncia } \\
\text { ordem, } \\
\text { pedido. }\end{array}$ & $\begin{array}{l}\text { modo imperativo (...) } \\
\text { em frases com que o } \\
\text { dor expressa uma } \\
\text { uma exortação, um }\end{array}$ & $\begin{array}{l}\text { TL: } \\
\text { 1. } 1 \\
2 .\end{array}$ & $\begin{array}{l}\text { nperativo (verbo). } \\
\text { mperativo }[g r] \text {. }\end{array}$ \\
\hline $\begin{array}{l}\text { Ex.: } \\
\text { 'uktub/q }\end{array}$ & & $\begin{array}{l}\text { Ex.: } \\
\text { "Penet } \\
\text { reino dc }\end{array}$ & $\begin{array}{l}\text { a surdamente no } \\
\text { s palavras." }\end{array}$ & $\begin{array}{r}\text { Fonte: } \\
1 . \\
2 . \\
\end{array}$ & $\begin{array}{l}\text { abbagh, } 2011 \text {, p. } 98 \text {; } \\
\text { 'orriente, } 1991 \text {, p. } 20\end{array}$ \\
\hline $\begin{array}{l}\text { Fonte: } \\
\text { Alhatīb d }\end{array}$ & Jațal, 1992, p. 142. & $\begin{array}{l}\text { Fonte: } \\
\text { Azered }\end{array}$ & 2010, p. 210 & & \\
\hline $\mathbf{P t}_{1774}$ & Imperativo & Es $_{1992}$ & Imperativo & Voc $_{1908}$ & Impératif \\
\hline $\mathbf{P t}_{2007}$ & Imperativo & $\mathrm{Fr}_{1911}$ & Impératif & Dic $_{1973}$ & Imperative \\
\hline $\mathbf{I n}_{1859}$ & Imperative & $\operatorname{In}_{1965}$ & Imperative & Dic $_{1983}$ & Imperative \\
\hline $\mathbf{I n}_{2005}$ & Imperative & & & & \\
\hline
\end{tabular}

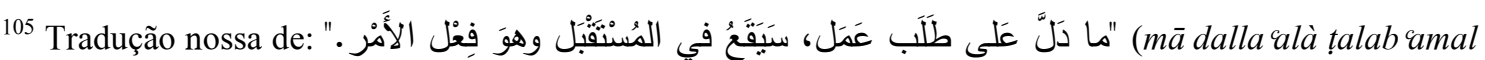
sayaqau fí almustaqbal wa huwa fil al'amr.)
} 
Percebe-se, após análise da ficha terminológica acima, que a correspondência entre o modo verbal árabe 'amr e o imperativo português é estritamente direta. Em ambas as línguas, há concordância entre o sema principal definidor deste modo: indicar um pedido/ordem. Por esse motivo, não se observam discordâncias entre os autores pesquisados, todos adotaram em suas línguas de chegada o mesmo termo correspondente.

Tal correspondência facilita a compreensão deste processo verbal pelo estudante estrangeiro, uma vez que é possível tecer comparações diretas com sua língua materna. Por isso, propõe-se que seja mantida a padronização do termo imperativo para designar o termo árabe 'amr.

\section{Os verbos läzim e $\operatorname{muta}^{c} a d d i n^{106}$ e a transitividade verbal}

Sempre se reconheceu a propriedade das classes predicadoras (verbos, adjetivos, advérbios e preposições) de exigir/ demandar /articular /

/subcategorizar determinados termos/ argumentos que lhes completem/ determinem/ especifiquem o sentido, constituindo juntamente com eles o predicado sentencial. (...) Denomina-se transitividade essa propriedade. (Castilho, 2010, p. 262)

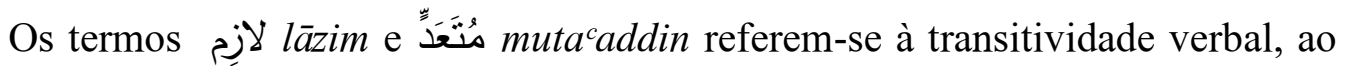
menos num primeiro olhar. Lipiński (1997, p. 331) exorta que interpretações inadequadas de alguns autores levam à confusão de características básicas do sistema verbal semítico, como, por exemplo, o traço transitivo e intransitivo dos verbos, uma vez que não correspondem exatamente à realidade descrita nas línguas indo-europeias.

Na epígrafe acima, Castilho define a transitividade verbal como a capacidade do verbo de exigir determinado argumento que lhe complete a significação. Em português, este argumento (complemento/objeto) pode ser direto ou indireto (quando introduzido pela preposição "a", segundo a classificação tradicional). Castilho defende ainda que a transitividade consista no "princípio da conexidade sintática, que faz da

\footnotetext{
${ }^{106} \mathrm{O}$ termo mutacaddin pertence ao grupo do 'ism manqūss, assim como o termo mädin.. Por esse motivo, apresentam-se duas transliterações para o termo, uma indeterminada mutacaddin, e a outra determinada almutacaddī.
} 
sequência de palavras uma sentença simples" (p. 328). Para ele, esta é uma propriedade da sentença e não do verbo que a constrói. Não haveria assim verbos exclusivamente transitivos ou intransitivos, seu uso na frase é que explicitaria a opção do falante. Os exemplos abaixo extraídos de Castilho (2010, p. 263) embasam sua argumentação:

(12) Vivo bem.

(13) Vivo uma vida boa.

No primeiro caso, o verbo "viver" é classificado como intransitivo, porque ele por si só constitui o predicado de uma oração (Azeredo, 2010, p. 213). Já no segundo uso, o falante selecionou um objeto direto para completar o sentido da predicação verbal.

Perini (2003, p. 162) rebate este tipo de proposição, dizendo que posicionamentos como o de Castilho têm como consequência o esvaziamento da noção de transitividade, que a tornaria supérflua. Suas críticas dão suporte a uma nova proposta de análise dos verbos que podem exigir, recusar ou aceitar livremente complemento $^{107}$.

Mattoso Câmara (1981, p.235) explica que o termo "transitivo", dado a tais verbos em latim, decorreu da possibilidade destes poderem passar (lat. transire) para a voz passiva, numa transformação em que o objeto direto é feito sujeito paciente. Os verbos intransitivos já não admitem esta transformação. Embora o termo "transitividade" seja sinônimo de predicação completa, o conceito estrito latino é aplicado também à língua portuguesa.

De acordo com a descrição presente na teoria gramatical árabe acerca dos verbos lāzim e mutacaddin, verificam-se semelhanças estreitas assim como divergências fundamentais com relação ao princípio da transitividade verbal.

Os gramáticos árabes Alḩawṣ (1987, p. 164) e Almacrī (2002, p. 52) concordam que os verbos lāzim são aqueles que necessitam apenas do sujeito para que a predicação verbal seja completa, plena de significado. Por esta definição conclui-se que os referidos verbos correspondem aos "intransitivos" portugueses, porque sozinhos constituem o predicado da oração (Azeredo, 2010, p. 213).

\footnotetext{
${ }^{107}$ Embora enriquecedores, esses embates teóricos não constituem o escopo desta pesquisa. Para mais detalhes, ver Castilho (2010, p. 262), Perini (2003, p. 162) e Azeredo (2010, p. 212).
} 
Frei Abrantes (1774, p.295) salienta que os verbos lāzim, ou intransitivos, não selecionam objeto, contudo, se a eles seguirem algum complemento, este será preposicionado. O que não quer dizer que tal complemento corresponda ao "objeto indireto" português. A gramática árabe classifica sua função simplesmente como sintagma preposicional ${ }^{108}$, o conceito de "objeto indireto" assim como ocorre na língua portuguesa é inexistente na língua árabe.

Outra semelhança que ratifica a correspondência com o verbo intransitivo português é o fato de as orações constituídas pelo verbo lāzim não poderem ser transpostas para a voz passiva.

O termo mutacaddin designa aqueles verbos que exigem, além do sujeito, um complemento que especifique sua significação sentencial, assegurando uma comunicação satisfatória. O complemento destes verbos é chamado, na teoria gramatical, de مَفْعول بِ mafcūl bihi, e estará sempre no caso no acusativo.

O fato de o complemento do verbo árabe, mafcūl bihi, apresentar-se no caso acusativo constitui um forte indício para a correspondência com o "objeto direto" português, cuja função sintática descende do acusativo latino. Assim sendo, há a

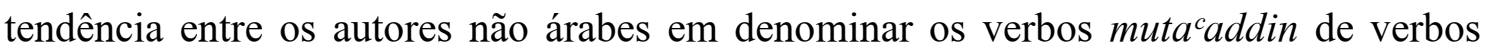
transitivos, no entanto, não há, em árabe, a oposição entre verbo transitivo direto e indireto, com seus respectivos objetos.

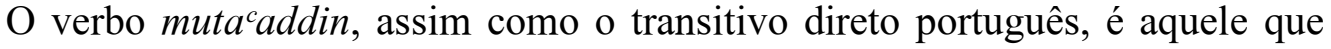
atende às exigências para a transformação da voz ativa para a passiva, em que o objeto direto passa a sujeito paciente da oração. A única diferença em ambas as línguas é que não é de interesse árabe recuperar o sujeito ativo por meio do agente da passiva, assim como ocorre em português.

\footnotetext{
${ }^{108}$ Os termos que designam preposição e sintagma nominal pós-preposição, em árabe, são harf jarr e ’ism majrūr, respectivamente.
} 
5.1 alficl allāzim - الفِعْل اللازِمِ

\begin{tabular}{|c|c|c|c|c|c|}
\hline \multicolumn{2}{|r|}{ Termo } & \multicolumn{2}{|c|}{$\begin{array}{c}\text { Possível correspondência } \\
\text { em Pt }\end{array}$} & \multicolumn{2}{|c|}{ Proposta de padronização } \\
\hline \multicolumn{2}{|c|}{ لازِمِ lāzim } & \multicolumn{2}{|c|}{ Intransitivo } & \multicolumn{2}{|r|}{ Intransitivo } \\
\hline \multicolumn{2}{|c|}{$\begin{array}{l}\text { DT: } \\
\text { "O verbo lāzim é aquele cujo } \\
\text { sujeito é suficiente para } \\
\text { completar o sentido da } \\
\text { oração, não necessitando de } \\
\text { mafúl bihi. }{ }^{110 "}\end{array}$} & \multicolumn{2}{|c|}{$\begin{array}{l}\text { DT: } \\
\text { “O verbo intransitivo típico é } \\
\text { aquele que constutui por si só } \\
\text { o predicado de uma oração. } \\
(\ldots) \text { (... }\end{array}$} & \multicolumn{2}{|c|}{$\begin{array}{l}\text { TL: } \\
\text { 1. Intransitivo (verbo). } \\
\text { 2. Intransitive. }\end{array}$} \\
\hline \multicolumn{2}{|c|}{$\begin{array}{l}\text { Ex.: } \\
\text { dahika ar-rajulu. } \\
\text { (O homem sorriu.) } \\
\text { nāma at-tiflu bākiran. } \\
\text { (A criança dormiu cedo.) }\end{array}$} & \multicolumn{2}{|c|}{$\begin{array}{l}\text { Ex.: } \\
\text { O dinheiro sobrava. } \\
\text { Seu filho nasceu. } \\
\text { A mancha sumirá. }\end{array}$} & \multicolumn{2}{|c|}{$\begin{aligned} \text { Fonte: } & \\
\text { 1. } & \text { Sabbagh, 2011, p. } 566 . \\
\text { 2. } & \text { Al-Mawrid, 1995, p. } \\
& 910 .\end{aligned}$} \\
\hline \multicolumn{2}{|c|}{$\begin{array}{l}\text { Fonte: } \\
\text { Almarī, 2002, vol. 1, p. } 52 .\end{array}$} & \multicolumn{2}{|c|}{$\begin{array}{l}\text { Fonte: } \\
\text { Azeredo, 2010, p. } 213 .\end{array}$} & & \\
\hline $\mathbf{P t}_{1774}$ & Intransitivo & $\mathbf{E s}_{1992}$ & --- & Voc $_{1908}$ & Intransitif(verbe) \\
\hline $\mathbf{P t}_{2007}$ & --- & $\mathbf{F r}_{1911}$ & Instransitif & Dic $_{1973}$ & Intransitive \\
\hline $\operatorname{In}_{1859}$ & Instransitive & $\operatorname{In}_{1965}$ & Instransitive & Dic $_{1983}$ & Intransitive verb \\
\hline $\mathbf{I n}_{2005}$ & Instransitive & & & & \\
\hline
\end{tabular}

Observou-se que a "transitividade verbal" em árabe não constitui um assunto deveras explorado e esmiuçado pelos estudiosos não árabes. Interessante notar que, até mesmo em livros didáticos e gramáticas árabe-árabe, o tema é abordado diferentemente, ou seja, quando o material é destinado a nativos, verifica-se a explanação plena desta característica verbal, ao passo que quando o foco é o ensino de árabe para estrangeiros a descrição é mais superficial, contando somente com a diferenciação básica e pertinente aos leitores alvo ${ }^{111}$.

Os gramáticos estudados, com exceção de Abrantes e Périer, apenas mencionam os termos "intransitivo" e "transitivo" quando discutem a categoria dos verbos e/ou dos nomes flexionados em acusativo. Alguns deles tangenciam o tema, outros, por sua vez, omitem-no.

${ }^{109} \mathrm{O}$ termo lāzim, que classifica os verbos com predicação completa, não deve ser confundido com a construção tipicamente coloquial lāzim 'an ("é preciso que..."). Este sintagma é formado pelo agentivo lāzim + partícula subjuntiva 'an e admite a inserção de uma oração que complete seu significado.

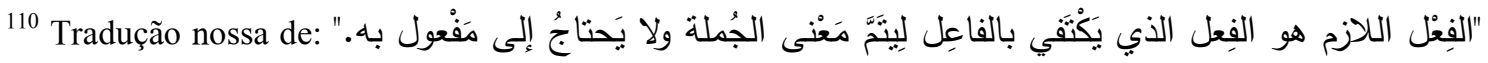

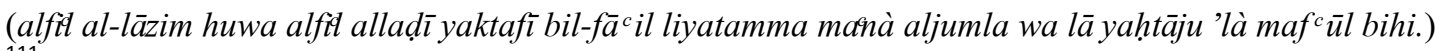

${ }^{111}$ Ver diferença na abordagem em Almacrī (2002, p. 52) e Alḩawș (1987, p.164). 
Frei Abrantes (1774, p. 295) oferece uma descrição completa sobre o tema, tal como é encontrado nas gramáticas árabes para nativos. $\mathrm{O}$ arabista português trata do tema no capítulo reservado à "Regência dos verbos". Neste, não há referência ao termo árabe genuíno, entretanto, pela definição apresentada para o "verbo intransitivo", deduzse que este se trata do verbo árabe lāzim.

Igualmente a Abrantes, Périer (1908, p. 199) reserva uma seção para discutir a regência dos verbos, em que trata do verbo designado por intransitif, no entanto, este autor restringe os verbos "intransitivos" como sendo aqueles que selecionam um complemento preposicionado. De fato, esta é uma possibilidade do verbo lāzim, porém não a sua essência. O sema principal deste verbo consiste em possuir uma predicação completa, juntamente com seu sujeito, assim como apresentado na DT árabe na ficha terminológica acima.

Wright (1859, p. 28) e Ryding (2005, p. 455/683) mencionam o termo "intransitivo" ao abordarem cada forma verbal derivada. Haywood \& Nahmad (1965, p. 393) apresentam o termo lāzim, designando-o por "intransitivo" no capítulo reservado ao "Uso dos casos". Nas três gramáticas supracitadas, não há maiores explicações e detalhamentos sobre o tema; evidenciam-se somente referências ao termo.

Em Corriente (1992) e Cowan (2007) não foi encontrada nenhuma citação ou referência ao termo árabe lāzim, nem ao possível termo correspondente "intransitivo". Corriente (1992, p. 195) aproxima-se da DT árabe acima ao definir "o sintagma verbal simples" como uma flexão verbal finita no pretérito perfeito, presente do indicativo ou imperativo ${ }^{112}$, como, por exemplo, a sentença imperativa qul, que significa "diga" e que possui predicação completa. Corriente (1992, p. 205) aborda os complementos preposicionados, contudo, não nomeia o tipo de verbo que seleciona tal complementação.

Ao analisar a ficha terminológica, verifica-se que, de fato, há correspondência entre os semas das definições terminológicas árabe e portuguesa. O sema principal que sinaliza a correspondência direta é não selecionar objeto que complete a predicação, 0 verbo por si só apresenta sentido completo.

Além disso, outra semelhança evidenciada entre o verbo árabe lāzim e o português "intransitivo" consiste na possibilidade de anexação de constituintes

\footnotetext{
112 Os termos "pretérito perfeito", "presente do indicativo" e "imperativo" não foram utilizados por Corriente (1992, p. 195) na citação original. Os termos originais foram substituídos pela terminologia proposta nesta pesquisa e já discutidas nas seções 2 a 4.
} 
preposicionados à sentença que não alterem a classe sintática destes verbos (Azeredo, 2010, p. 213), como, por exemplo:

(14) Seu filho nasceu no exterior.

O sintagma preposicional em itálico indica o local do nascimento do menino sem alterar a transitividade o verbo nascer.

(15) Marrartu bi-ššāaric (Andei pela rua.)

Da mesma forma como em português, o sintagma preposicional em itálico e negrito indica o local percorrido, e não altera a transitividade do verbo árabe andar. Além disso, como mencionado anteriormente, o verbo lāzim não admite transposição para a voz passiva árabe.

Por isso, sugere-se que seja seguida a tendência dos autores não árabes pesquisados e listados acima em designar o verbo árabe lāzim por intransitivo em português, pois foi verificada a correspondência direta entre ambos os termos e os processos que denotam. 


\section{2 alficl almutac addi}

\begin{tabular}{|c|c|c|c|c|c|}
\hline & Termo & \multicolumn{2}{|c|}{$\begin{array}{c}\text { Possível correspondência } \\
\text { em Pt }\end{array}$} & \multicolumn{2}{|c|}{ Proposta de padronização } \\
\hline \multicolumn{2}{|c|}{ mutacaddin مُنَعَدِّد } & \multicolumn{2}{|c|}{ Transitivo } & \multicolumn{2}{|r|}{ Transitivo } \\
\hline \multicolumn{2}{|c|}{$\begin{array}{l}\text { DT: } \\
\text { "O verbo mutacaddī é aquele } \\
\text { cujo sujeito não é suficiente, } \\
\text { necessita do mafūl bihi para } \\
\text { completar o sentido da } \\
\text { oração. }{ }^{113 ",}\end{array}$} & \multicolumn{2}{|c|}{$\begin{array}{l}\text { DT: } \\
\text { "Outros, ao contrário, } \\
\text { requerem, para cabal } \\
\text { integridade do predicado, a } \\
\text { presença de um ou mais } \\
\text { termos que lhes completem a } \\
\text { compreensão. São os verbos } \\
\text { transitivos." }\end{array}$} & \multicolumn{2}{|c|}{$\begin{array}{ll}\text { TL: } & \\
\text { 1. } & \text { Transitivo (verbo). } \\
\text { 2. } & \text { Transitivo. }\end{array}$} \\
\hline \multicolumn{2}{|c|}{$\begin{array}{l}\text { Ex.: } \\
\text { haṣada alfalāhu az-zaraca. } \\
\text { (O agricultor colheu a } \\
\text { plantação.) } \\
\text { kataba alwaladu ar-risālata. } \\
\text { (O menino escreveu a carta.) }\end{array}$} & \multicolumn{2}{|c|}{$\begin{array}{l}\text { Ex.: } \\
\text { Resumirei a história. } \\
\text { Descasque o abacaxi. } \\
\text { Não acredito em fantasmas. }\end{array}$} & \multicolumn{2}{|c|}{$\begin{array}{l}\text { Fonte: } \\
\text { 1. Sabbagh, 2011, p. } 596 . \\
\text { 2. } \text { Corriente, 1991, p. } 500 .\end{array}$} \\
\hline \multicolumn{2}{|c|}{$\begin{array}{l}\text { Fonte: } \\
\text { Almarī, 2002, vol. 1, p. } 52 .\end{array}$} & \multicolumn{2}{|c|}{$\begin{array}{l}\text { Fonte: } \\
\text { Lima, 2002, p. } 238 .\end{array}$} & & \\
\hline $\mathbf{P t}_{1774}$ & Transitivo & $\mathbf{E s}_{1992}$ & Transitivo & Voc $_{1908}$ & Transitif (verbe) \\
\hline $\mathbf{P t}_{2007}$ & Transitivo & $\mathbf{F r}_{1911}$ & Transitif & Dic $_{1973}$ & Transitive \\
\hline $\mathbf{I n}_{1859}$ & Transitive & $\mathrm{In}_{1965}$ & Transitive & Dic $_{1983}$ & Transitive verb \\
\hline $\mathbf{I n}_{2005}$ & Transitive & & & & \\
\hline
\end{tabular}

A ficha terminológica acima evidencia que o caráter transitivo do verbo árabe foi abordado por todos os autores pesquisados, mesmo que em graus diferenciados e sem mencionar o termo árabe mutac $^{c}$ addin, na maioria das vezes.

Abrantes (1774, p. 299) e Périer (1911, p. 197) detalham as nuances do verbo mutacaddin, assim como está presente nas gramáticas árabes para nativos. Frei Abrantes é ainda mais minucioso que Périer, destacando todos os usos possíveis dos verbos que selecionam argumento interno para complementar sua predicação.

Wright $(1859$, p. 28) menciona somente quais as formas verbais derivadas são transitivas, assim como faz no caso intransitivo. O motivo do autor não tocar na complementação verbal, aspecto indispensável da língua, justifica-se no prefácio da

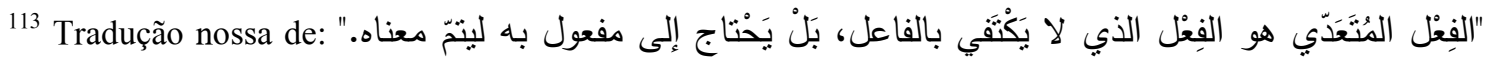
(alficl almutacddī huwa alficl allad̄i la yaktafí bil-făcil bal yahtāju 'ilà maf́ūl bihi liyatamma macanāhu.) É interessante notar que o significado original do vocábulo é "transcender, exceder, passar além, ir além, passar por cima".
} 
gramática, onde explica que abordará apenas a ortografia e a morfologia árabe na presente obra, a sintaxe constitui o foco do número seguinte. Em seu volume II, Wright (1862, p. 31) retoma o assunto detalhadamente, apresenta a terminologia árabe e reafirma o termo transitive verbs para os verbos que regem seu complemento em acusativo.

Haywood \& Nahmad (1965, p. 393) apresenta a terminologia árabe ao lado do termo inglês transitive, quando estuda os nomes acusativos, uma vez que o objeto direto

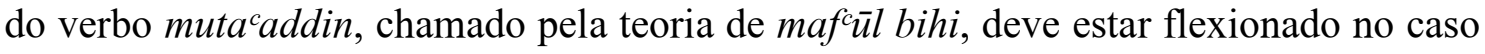
acusativo, obrigatoriamente.

Corriente (1992, p. 197) cita os "verbos transitivos" no capítulo reservado ao que o autor chama de "extensões nominais do sintagma verbal", onde tratará dos sintagmas nominais flexionados no caso acusativo. Não há menção ao termo original mutacaddin.

Ryding (2005, p. 172) aborda os "verbos transitivos" quando estuda o caso acusativo e ao detalhar as formas derivacionais das raízes verbais. A autora disponibiliza, ao final de sua gramática, um glossário de termos técnicos, onde há a

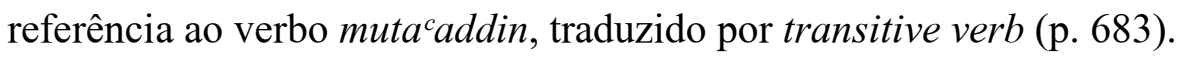

Cowan (2007, p. 94) emprega o termo "verbo simples transitivo" quando trata da forma passiva dos verbos no presente. O termo "transitivo" é mencionado novamente ao tratar das formas derivacionais verbais (p. 147).

Mesmo que Lipińsk (1997, p. 331) afirme que a transitividade verbal conhecida nas línguas indo-europeias não corresponda exatamente à realidade linguística semítica, todos os gramáticos e lexicógrafos investigados lançam mão do termo "transitivo" para designar a categoria dos verbos mutacaddin. Além deste fato, as definições terminológicas de ambas as línguas possuem semas concordantes, o que permite concluir que denotam processos linguísticos coincidentes, ou pelo menos, semelhantes.

Desta forma, propõe-se que seja seguida a padronização internacional e adotese, em português, o termo transitivo ${ }^{114}$ para designar o verbo árabe em questão.

\footnotetext{
${ }^{114}$ Tanto o verbo unta $^{c}$ addin árabe quanto o transitivo português apresentam subdivisões não abordadas nesta pesquisa, pois foi seguida a orientação dos materiais didáticos árabes voltados para estrangeiros que apresentam apenas a segmentação básica entre os verbos lāzim - intransitivos e mutacaddin - transitivos.
} 


\section{A voz do verbo árabe e português: categorias correspondentes?}

A voz verbal, em português, pode ser definida como sendo "a forma sintática que o predicado assume para atribuir um papel semântico ${ }^{115}$ ao respectivo sujeito" (Azeredo, 2010, p. 270). Expressa-se por meio de recursos sintáticos que definem padrões formais determinados para o sintagma verbal. Qualquer verbo está propenso a variações morfológicas e flexionais, contudo, distinções de voz é caráter privativo dos verbos transitivos diretos.

Distinguem-se três vozes verbais na língua portuguesa, a ativa, a passiva e a reflexiva. A tradição gramatical propõe que, na voz ativa, o verbo atribua ao sujeito o papel de /agente/ e ao objeto direto o papel de /paciente/:

(16) A menina comeu um pedaço de bolo.

Mattoso Câmara (1981, p. 244) explica que a denominação "ativa” é decorrente do tratamento dado ao verbo, ou seja, quando este é considerado uma ação, uma atividade de determinado ser sujeito de quem parte o processo verbal.

Azeredo (2010, p. 270) acrescenta que a voz ativa é comum aos verbos transitivos e intransitivos e que o papel de /agente/ atribuído ao sujeito é apenas um dentre os possíveis. A voz ativa é expressa formalmente por um sintagma verbal simples, assim como não há um recurso gramatical particular que a determine, por isso, é considerada como a "forma não marcada do sistema de vozes".

O verbo passivo, ao contrário do ativo, atribui ao sujeito o papel de /paciente/ e ao complemente direto o papel de /agente/. Em outras palavras, esta é a forma explícita de se atribuir ao paciente da ação verbal o papel de sujeito da oração (Azeredo, 2010, p. 273).

(17) As roseiras são podadas pelo jardineiro.

\footnotetext{
${ }^{115}$ Castilho (2010, p. 253) assim define os papeis temáticos (ou semânticos): "são traços semânticos atribuídos por um predicador ao seu escopo". Segundo o autor, os papeis temáticos dispõem de uma base cognitiva universal, diferindo das categorias estritamente sintáticas que possuem particularidades nas diferentes línguas naturais. Não há, também, uma correspondência biunívoca entre as funções sintáticas de sujeito, complemento e adjunto e os papeis semânticos de agentivo, beneficiário, passivo, entre outros que lhes são atribuídos. Para maiores detalhes, ver Castilho (2010, p. 253-258).
} 
A voz passiva, própria dos verbos transitivos diretos, é formalmente marcada pelo verbo auxiliar ser seguido do particípio do verbo principal; esta, portanto, constitui a formação passiva padrão ${ }^{116}$.

O mesmo conteúdo objetivo expresso pela voz passiva pode ser veiculado por meio de sua forma ativa correspondente:

(18) O jardineiro poda as roseiras.

Perini (2003, p. 218) alerta para o fato de que esta correspondência é parcial, pois apesar de toda passiva possuir uma ativa correspondente, a recíproca não é verdadeira, uma vez que há verbos que não admitem o traço de passividade, como o verbo ter, típico de construções ativas ${ }^{117}$.

Azeredo (2010, p. 274) ensina que se as sentenças (17) e (18) forem comparadas fora de contexto, estas podem ser consideradas formas diferentes para o mesmo significante, todavia, há motivações discursivas ou pragmáticas que selecionam uma ou outra forma. A construção passiva possui a particularidade de realçar o paciente e permitir a omissão do real agente da ação verbal, como em:

(19) As roseiras são podadas.

(20) Podam-se as roseiras.

Na frase (20), chamada de passiva sintética ou pronominal (Azeredo, 2010, p. 274), o agente do processo verbal encontra-se obrigatoriamente indeterminado, isto é, trata-se de uma estratégia sintática de indeterminação do sujeito /agente/, pois o item "roseiras" é considerado o sujeito sentencial /paciente/. Certos linguístas prevêm a estrutura ativa "poda-se roseiras", em que o constituinte "roseiras" é classificado como objeto direto e o sujeito sentencial /agente/ encontra-se indeterminado.

No terceiro tipo, a voz reflexiva, o verbo atribui ao sujeito o papel de /agente/ e /paciente/, simultaneamente:

(21) A menina enfeitou-se para a festa.

\footnotetext{
${ }^{116}$ Castilho (2010, p. 436) distingue entre a voz passiva típica (ou padrão) e resultativa, formada pelo verbo estar + particípio do verbo principal. Segundo o mesmo autor (p. 437), a forma passiva resultativa é mais frequente em narrativas, textos de instrução e em outras situações em que se precise tirar consequências de um estado de coisas anterior.

${ }^{117}$ Se excluído seu emprego no sentido de "considerar", como, por exemplo, ele é tido por louco.
} 
Nesta, o sujeito e o objeto são correferenciais (Castilho, 2010, p. 437), em que "menina" e "se" referem-se ao mesmo indivíduo. A voz reflexiva é característica dos verbos transitivos direto, assim como a voz passiva.

Considerações minuciosas acerca das vozes do verbo português podem ser encontradas em qualquer gramática da língua, recomenda-se a verificação em Castilho (2010), Azeredo (2010), Perini (2003) por disponibilizarem ao leitor uma visão que, embora perpasse as proposições normativas, descreve o português brasileiro sob o prisma das análises linguísticas contemporâneas.

Passa-se agora à gramática árabe, com o intuito de investigar se esta língua apresenta distinções de voz, assim como as línguas indo-europeias, que possibilitem estabelecer uma correspondência direta com os verbos ativos e passivos portugueses.

Quanto à relação entre o predicado e o sujeito sentencial, a teoria gramatical segmenta os verbos em المبني للمعلوم almabnī lil-maclūm e المبني للمجهول almabnì lilmajhül. Estes termos podem ser traduzidos, de modo literal, por "o construído para o conhecido" e "o construído para o ignorado", respectivamente.

$\mathrm{O}$ primeiro termo refere-se àquelas construções em que o sujeito agente aparece explícito, determinado, ou seja, é conhecido tanto pelo falante quanto por seu interlocutor.

(22) kasara aš-šubāka.

Ele quebrou a janela.

(23) mašāt albintu fìl-ḥadīqati.

A menina caminhou pelo jardim.

Observa-se que o sujeito é conhecido e determinado em ambas as sentenças acima, mesmo que em (22) sua posição não esteja sintaticamente preenchida em árabe, pode ser recuperada no pronome chamado "oculto" "118, diferentemente de (23), em que o item "menina" representa o sujeito sentencial.

Orações deste tipo são denominadas em árabe de almabnī lil-maclūm. Pode-se afirmar que esta classe represente a forma não marcada, uma vez que abarca todas as orações em que o sujeito sentencial é semanticamente conhecido pelo falante e por seu

${ }^{118}$ Conhecido, em árabe, pelo termo ضُamīr mustatir, "pronome oculto", é depreendido por meio da flexão verbal e não por um lexema explícito na frase. 
interlocutor. Assim como a forma ativa portuguesa, que inclui tanto os verbos transitivos quanto os intransitivos, a construção sentencial árabe almabnī lil-maclūm abrange tanto os verbos lāzim - intransitivos (23) como mutacadin - transitivos (22).

O segundo termo indica aquelas sentenças onde o sujeito agente não é expresso, é ignorado, consciente ou inconscientemente. Quando um falante árabe utiliza a construção almabnī lil-majhūl, ou ele não sabe quem praticou a ação expressa pelo verbo ou não é de seu interesse comunicá-lo. Se o agente da oração for mencionado, a construção almabnī lil-maclūm deve ser usada (Cowan, 2007, p. 67). Não se observa correspondência semântica entre sentenças almabnī lil-maclūm e almabnī lil-majhūl, ao contrário do que o ocorre em português, em que uma oração passiva possui sua correspondente ativa, comunicando o mesmo conteúdo objetivo (Azeredo, 2010, p. 274).

Em português, é possível afirmar que as orações abaixo (24) e (25) veiculam o mesmo conteúdo, ainda que a escolha por uma ou outra tenha motivações discursivas ou pragmáticas específicas. O mesmo não pode ser dito das orações árabes (26) e (27), pois na última não há menção quanto ao sujeito /agente/ da ação verbal de escrever. Tem-se aí uma indeterminação do sujeito.

(24) O escritor famoso escreveu este livro.

(25) Este livro foi escrito pelo escritor famoso.

(26) kataba alkātibu almašhūru had̄ā alkitaba. (igual a 24)

(27) kutiba had̄a alkitabu. (Escreveu-se este livro./ Este livro foi escrito.)

É importante citar que apenas as orações que possuem verbo transitivo podem ser transpostas da forma almabnī lil-maclūm para a almabnī lil-majhūl. Esta exigência também é vigente na língua portuguesa, quando da transformação da voz ativa para a passiva, esta característica é uma das motivações para que os gramáticos não árabes designem estas formas pela terminologia "ativa" e "passiva".

No entanto, Corriente (1992, p. 162) critica os gramáticos não árabes que costumam utilizar os termos "voz ativa e passiva" em suas línguas. Segundo o autor, esta terminologia possui o inconveniente de coincidir apenas parcialmente com o conteúdo semântico dos termos almabnī lil-maclūm e almabnī lil-majhūl, por esse motivo que a opção terminológica do gramático espanhol foi a única que destoou das outras presentes na ficha que será analisada em seguida. 
Morfologicamente, o verbo almabn̄̄ lil-maclūm difere do almabnī lil-majhūl somente pelo paradigma vocálico, tanto do presente do indicativo ${ }^{119}$ quanto do pretérito perfeito.

Considerando os pontos acima apresentados, destacam-se as seguintes características, formalizadas na tabela 8 , que visam auxiliar a designação destes dois termos árabes em português:

\begin{tabular}{|l|c|c|c|c|}
\cline { 2 - 5 } \multicolumn{1}{c|}{} & \multicolumn{2}{c|}{ Português } & \multicolumn{2}{c|}{ Árabe } \\
\cline { 2 - 5 } \multicolumn{1}{c|}{} & Voz ativa & Voz passiva & $\begin{array}{c}\text { almabnī } \\
\text { lil-maclūm }\end{array}$ & $\begin{array}{c}\text { almabnī } \\
\text { lil-majhūl }\end{array}$ \\
\hline Semelhança & $\begin{array}{c}\text { Forma } \\
\text { não } \\
\text { marcada }\end{array}$ & $\begin{array}{c}\text { Verbos } \\
\text { transitivos } \\
\text { direto }\end{array}$ & $\begin{array}{c}\text { Forma não } \\
\text { marcada }\end{array}$ & $\begin{array}{c}\text { Verbos } \\
\text { transitivos }\end{array}$ \\
\hline Diferença & $\begin{array}{c}\text { Sujeito } \\
\text { /agente/ }\end{array}$ & $\begin{array}{c}\text { Sujeito } \\
\text { /paciente/ }\end{array}$ & $\begin{array}{c}\text { O sujeito é } \\
\text { conhecido, } \\
\text { determinado. } \\
\text { Pode ser } \\
\text { /agente/ ou } \\
\text { /paciente/ }\end{array}$ & $\begin{array}{c}\text { Sujeito } \\
\text { ignorado, } \\
\text { indeterminado. } \\
\text { Sujeito } \\
\text { /paciente/ }\end{array}$ \\
\hline
\end{tabular}

Tabela 8: Semelhanças e diferenças entre a voz ativa/ passiva árabe e portuguesa

${ }^{119}$ A construção do verbo almabnī lil-majhūl, no presente, é feita colocando o damma na primeira consoante radical e o fatha na penúltima, como, por exemplo, yuktabu ("é escrito"). E no pretérito perfeito, basta colocar o damma na primeira consoante radical e o kasra na penúltima, como em kutiba ("foi escrito"). 


\section{1 alficl almabnī lil-maclūm}

\begin{tabular}{|c|c|c|c|c|c|}
\hline \multicolumn{2}{|r|}{ Termo } & \multicolumn{2}{|c|}{$\begin{array}{c}\text { Possível correspondência } \\
\text { em Pt }\end{array}$} & \multicolumn{2}{|c|}{ Proposta de padronização } \\
\hline \multicolumn{2}{|c|}{$\begin{array}{c}\text { المَبْني للِلمَعْلُوم } \\
\text { almabnī lil-madūm }\end{array}$} & \multicolumn{2}{|c|}{ Voz ativa } & \multicolumn{2}{|r|}{ Voz ativa } \\
\hline \multicolumn{2}{|c|}{$\begin{array}{l}\text { DT: } \\
\text { "O verbo almabnī lil-madūm } \\
\text { é aquele cujo sujeito é } \\
\text { conhecido. }{ }^{120, "}\end{array}$} & \multicolumn{2}{|c|}{$\begin{array}{l}\text { DT: } \\
\text { "Costuma-se dizer que na } \\
\text { voz ativa o sujeito pratica a } \\
\text { ação, é o agente." }\end{array}$} & \multicolumn{2}{|c|}{$\begin{aligned} & \mathbf{T L}^{\mathbf{1 2 1}} \text { : } \\
& \text { 1. } \text { Sabido. Ativo (verbo). } \\
& \text { 2. } \text { Conocido, } \\
& \text { determinado. Activo, } \\
& \text { agentivo [gr]. } \\
&\end{aligned}$} \\
\hline \multicolumn{2}{|c|}{$\begin{array}{l}\text { Ex.: } \\
\text { kasara alwaladu aš-šubāka. } \\
\text { (O menino quebrou a janela.) }\end{array}$} & \multicolumn{2}{|c|}{$\begin{array}{l}\text { Ex.: } \\
\text { Laura penteia Clarisse. } \\
\text { O menino quebrou a janela. }\end{array}$} & \multicolumn{2}{|c|}{$\begin{aligned} \text { Fonte: } & \\
\text { 1. } & \text { Sabbagh, 2011, p. } 569 . \\
\text { 2. } & \text { Corriente, 1991, p. } 531 .\end{aligned}$} \\
\hline \multicolumn{2}{|c|}{$\begin{array}{l}\text { Fonte: } \\
\text { Almarī 2002, vol. 1, p. } 55 .\end{array}$} & \multicolumn{2}{|c|}{$\begin{array}{l}\text { Fonte: } \\
\text { Azeredo, 2010, p. } 270 .\end{array}$} & & \\
\hline $\mathbf{P t}_{1774}$ & Activo & $\mathbf{E s}_{1992}$ & Agentivo & Voc $_{1908}$ & Voix active \\
\hline $\mathbf{P t}_{2007}$ & Ativo & $\mathbf{F r}_{1911}$ & Actif & Dic $_{1973}$ & Active voice \\
\hline$I_{1859}$ & Active & $\operatorname{In}_{1965}$ & Active & Dic $_{1983}$ & Active voice \\
\hline $\mathbf{I n}_{2005}$ & Active & & & & \\
\hline
\end{tabular}

A ficha terminológica acima mostra que houve consenso quanto à padronização do termo almabnī lil-maclūm, uma vez que a maioria dos autores não árabes pesquisados tenha adotado como correspondente o termo "voz ativa". A exceção foi o gramático espanhol Corriente que preferiu agentivo à "voz ativa" para designar o termo em estudo, justificando que tanto o termo "voz ativa" quanto "voz passiva" coincide apenas parcialmente com o conteúdo semântico dos verbos almabnī lil-maclūm e almabnī lil-majhūl (Corriente, 1992, p. 162).

Segundo o dicionário eletrônico Houaiss (2007), "agentivo" apresenta duas acepções linguísticas. Na primeira é tido como "relativo a agente", na segunda, reflete o “caso ou declinação que exprime o agente (aquele que pratica a ação)”. Já a DT do termo árabe em análise define-o como "aquele cujo sujeito é conhecido" e não aquele

\footnotetext{
120 Tradução nossa de: "العفل المبني للمعلوم هو الذي يُعْرَفُ فاعلُهُ. (alficl almbnī lil-maclūm huwa allad̄i yucrafu fāciluhu.)

${ }^{121}$ O lexema المبني, presente em ambos os termos, significa exatamente “o construído”, como já foi traduzido anteriormente, não foi incluído neste campo da ficha.
} 
cujo sujeito é o agente da ação expressa pelo verbo, definição correspondente à voz ativa portuguesa.

Observe as sentenças abaixo:

(28) laciba al'awlādu kurata-l-qadami.

Os meninos jogaram bola.

(29) infataḥa albābu.

A porta abriu-se.

Ambos os verbos acima são tratados, em árabe, como almabnī lil-maclūm, tanto o padrão vocálico dos verbos laciba ("jogar") e infataha ("abrir-se") quanto o sujeito sentencial presente e conhecido confirmam esta informação. Em (28), o sujeito "os meninos" efetivamente corresponde ao /agente/ do verbo "jogar", porém em (29), não se pode afirmar que "a porta" seja apenas o /agente/ da ação "abrir-se" e sim seu /agente/ e /paciente/, isto porque o verbo infataḩa pertence à forma derivacional VII que denota o conceito reflexivo-passivo (Gomes, 2011, p. 66).

Para o processo verbal almabnī lil-maclūm, o que importa é que o sujeito sentencial seja conhecido e determinado pelo falante e por seu interlocutor, sendo ele agente da ação verbal, como ocorre na voz ativa portuguesa e encontra-se ilustrado em (28), ou não, como presente no exemplo (29) onde o sujeito "porta" não representa apenas o agente da ação "abrir".

Retorna-se, portanto, ao termo adotado pelos outros autores, considerando a já mencionada explicação de Câmara (1981, p. 244). Este afirma que o verbo chamado de "ativo" é tido como uma ação, uma atividade de determinado ser. Esta explicação para os verbos ativos portugueses coincide com os verbos almabnī lil-maclūm, que, embora possam denotar conceito reflexivo-passivo, informam uma ação.

Por isso, propõe-se que seja adotada, em língua portuguesa, a terminologia voz ativa para designar o termo árabe almabnī lil-maclūm. 


\section{2 alficl almabnī lil-majhūl}

\begin{tabular}{|c|c|c|c|c|}
\hline \multicolumn{2}{|r|}{ Termo } & $\begin{array}{c}\text { Possível correspondência } \\
\text { em Pt }\end{array}$ & \multicolumn{2}{|c|}{ Proposta de padronização } \\
\hline \multicolumn{2}{|c|}{ 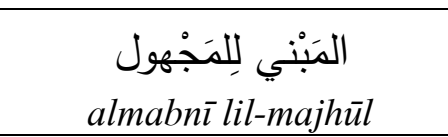 } & Voz passiva & \multicolumn{2}{|r|}{ Voz passiva } \\
\hline \multicolumn{2}{|c|}{$\begin{array}{l}\text { DT: } \\
\text { "O verbo almabnī lil-majhūl } \\
\text { é aquele cujo sujeito não é } \\
\text { conhecido. } 22, "\end{array}$} & $\begin{array}{l}\text { DT: } \\
\text { "Por sua vez, a voz passiva } \\
\text { se caracteriza formalmente } \\
\text { pela presença do verbo } \\
\text { auxiliar ser seguido de } \\
\text { participio e semanticamente } \\
\text { por atribuir ao sujeito, } \\
\text { regularmente, o papel de } \\
\text { paciente ou ser afetado pelo } \\
\text { processo que o verbo } \\
\text { exprime; (...)." }\end{array}$ & \multicolumn{2}{|c|}{$\begin{aligned} \text { TL: } & \\
\text { 1. } & \text { Ignorado, } \\
& \text { desconhecido, } \\
& \text { anônimo. Verbo } \\
& \text { passivo Gram. } \\
\text { 2. } & \text { Desconocido. Voz } \\
& \text { passiva }[\mathrm{gr}] .\end{aligned}$} \\
\hline \multicolumn{2}{|c|}{$\begin{array}{l}\text { Ex.: } \\
\text { kusira a ̌̌- ̌̌s } b \bar{a} k u . \\
\text { (A janela foi quebrada.) }\end{array}$} & $\begin{array}{l}\text { Ex.: } \\
\text { Clarisse é penteada por } \\
\text { Laura. }\end{array}$ & \multicolumn{2}{|c|}{$\begin{aligned} \text { Fonte: } & \\
\text { 1. } & \text { Sabbagh, 2011, p. } 608 . \\
\text { 2. } & \text { Corriente, 1991, p. } 131\end{aligned}$} \\
\hline \multicolumn{2}{|c|}{$\begin{array}{l}\text { Fonte: } \\
\text { Almarī, 2002, vol. 1, p. } 55 .\end{array}$} & $\begin{array}{l}\text { Fonte: } \\
\text { Azeredo, 2010,p. } 271 .\end{array}$ & & \\
\hline $\mathbf{P t}_{1774}$ & Passivo & \begin{tabular}{l|l} 
Es $_{\mathbf{1 9 9 2}}$ & Voz no-agentiva \\
\end{tabular} & Voc $_{1908}$ & Passif \\
\hline $\mathbf{P t}_{2007}$ & Passivo & Passif & Dic $_{1973}$ & Passive voice \\
\hline $\mathbf{I n}_{1859}$ & Passive & Passive & Dic $_{1983}$ & Passive voice \\
\hline $\mathbf{I n}_{2005}$ & Passive & & & \\
\hline
\end{tabular}

Se a análise deste termo árabe fosse iniciada pelas definições terminológicas apresentadas, poderia ser declarado que os termos almabnī lil-majhūl e "voz passiva" não representam processos linguísticos correspondentes, no entanto, esta discussão ultrapassa o conteúdo das definições na busca de indícios que justifiquem o porquê que nove entre dez autores pesquisados utilizaram o termo "passivo" a fim de designar os verbos almabnī lil-majhūl.

Verificou-se que a tendência em relacionar verbos almabnī lil-majhūl com a voz passiva das línguas indo-europeias remonta, pelo menos, ao século XVIII, quando a primeira gramática árabe em português foi escrita em (1774). Frei Abrantes (1774, p. 162) não tece grandes considerações acerca desta estrutura, demonstra apenas como se

\footnotetext{
${ }^{122}$ Tradução nossa de: "العفل المبني للمجهول هو الذي لا يُعْرَفُ فاعلُهُ. (alficl almabnī lil-majhūl huwa allad̄i lā yucrafu făciluhu.)
} 
dá a alteração flexional da forma ativa para passiva, assim como determina quais os tempos e os modos que se adaptam a tal construção.

Wright $(1859$, p. 45) enumera quatro situações que selecionam o uso do verbo almabnì lil-majhūl, são elas:

a) Quando Deus ou algum ser superior é indicado como autor do ato;

b) Quando o sujeito agente é ignorado ou não conhecido ao certo;

c) Quando o enunciador não deseja nomeá-lo;

d) Quando a atenção do interlocutor está mais direcionada à pessoa afetada (paciente) pelo fato do que no agente da ação.

Soma-se aos usos anteriores uma quinta possibilidade, citada por Corriente (1992, p. 163) e por Haywood \& Nahmad (1965, p. 144), trata-se das sentenças impessoais, como os verbos yuqālu (“diz-se"), dukira (“mencionou-se").

Das cinco possibilidades de uso descritas acima, verifica-se que, com exceção da primeira, o denominador comum é a omissão do agente da ação. A teoria gramatical árabe prescreve o uso da forma almabnī lil-majhūl quando não se sabe ou não é de interesse citar o agente da ação verbal. Quando o mesmo é mencionado, "não se pode usar a voz passiva" (Cowan, 2007, p. 67), prefere-se, então, a forma ativa do verbo. Por esse motivo, Périer (1911, p. 201) afirma que a estrutura almabnī lil-majhūl é pouco usada em árabe. Em português, a voz passiva abre o precedente para a omissão do sujeito /agente/, uma vez que a voz passiva "aparece quando se deseja ressaltar o resultado de uma ação anterior" (Castilho, 2010, p. 437) e não seu agente. Este pode ser introduzido na sentença passiva padrão por meio do complemento preposicionado chamado de agente da passiva, ou nem mesmo ser mencionado, como ocorre nas passivas pronominais (ou sintéticas), nas quais o agente encontra-se obrigatoriamente indeterminado (Azeredo, 2010, p. 274).

Devido a influências das línguas indo-europeias, Corriente (1992, p. 162) e Haywood \& Nahmad (1965, p. 143) alertam para o fato de que é possível encontrar na língua árabe contemporânea sentenças formadas com verbo almabnī lil-majhūl, em que o agente da ação esteja presente e seja introduzido pelos sintagmas preposicionados min tarafi e هِنْ فِنْ طِ min qibali ("por parte de"), contudo, estes não constituem usos genuínos árabes, são frutos de traduções, mais comuns em textos jornalísticos. 
Ryding (2005, p.657) propõe que, em árabe, há duas maneiras de se expressar as construções passivas, uma flexional ou interna e a outra derivacional. A passiva flexional refere-se exatamente ao processo expresso pelo termo almabnī lil-majhūl. Chama-se flexional ou interna porque depende da flexão interna do verbo, isto é, da alteração de seu padrão vocálico.

A passiva derivacional indica as três formas verbais derivadas ${ }^{123}$ que veiculam um significado reflexivo-passivo, apesar de pertencerem à estrutura verbal ativa, ou seja, aquela cujo sujeito sentencial é conhecido e determinado. Ryding (2005, p. 657) salienta que tais formas verbais refletem um estado resultativo do objeto, como ilustrado na oração abaixo:

(30) fataḥtu albābu fa'infataha.

Abri a porta e ela se abriu.

Wright (1859, p. 46) adverte que o conceito passivo expresso pelo tipo flexional e derivacional não podem ser tomados como idênticos, este é considerado como efetivo ou resultativo, como Ryding explicita; enquanto aquele é a forma tida como puramente passiva.

Corriente (1992, p. 162) optou pela terminologia não-agentivo para designar o termo árabe almabnī lil-majhūl. Esta atende à delimitação proposta pela DT árabe, cujo sema principal é sujeito /agente/ não ser conhecido, determinado. O sujeito sintático que aparece neste tipo de estrutura sentencial é denominado, na teoria gramatical, $n a$ ’ $b$ alfăcil - "o substituto do sujeito", o que na realidade indica o sujeito/paciente/, ou seja, não agentivo.

Verifica-se, então, que o processo verbal almabnī lil-majhūl constitui uma estratégia de indeterminação do sujeito /agente/ da ação verbal e que, na verdade, o sujeito sentencial apenas preenche esta posição sintática. Da mesma forma acontece com a voz passiva pronominal (ou sintética) portuguesa que funciona como estratégia de indeterminação do sujeito/agente/. A fim de se manter um paralelismo didático entre a terminologia proposta para o termo anterior almabnī lil-maclūm - voz ativa, sugere-se

\footnotetext{
${ }^{123}$ As três formas verbais derivadas que denotam o conceito reflexivo-passivo são a forma $\mathrm{V}$ - تَفَعَّلَ

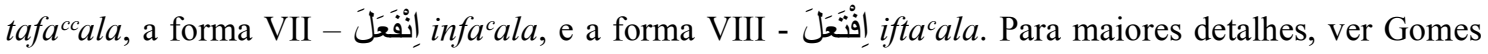
(2010, p. 64).
} 
que seja mantido o termo voz passiva, uso já padronizado entre a maioria dos autores pesquisados, na tarefa de designar os verbos almabnī lil-majhūl. 
7. الأَفْعال الناقِصَة al'af'āl an-nāqiṣa

\begin{tabular}{|c|c|c|c|}
\hline Termo & $\begin{array}{c}\text { Possível } \\
\text { correspondência }{ }_{1} \text { em } \\
\text { Pt }\end{array}$ & $\begin{array}{c}\text { Possível } \\
\text { correspondência }{ }_{2} \text { em } \\
\text { Pt }\end{array}$ & $\begin{array}{c}\text { Proposta de } \\
\text { padronização: }\end{array}$ \\
\hline أَفْعال ناقصةة & Verbo defectivo & Verbo de ligação & $\begin{array}{l}\text { Verbo kāna e seus } \\
\text { semelhantes }\end{array}$ \\
\hline $\begin{array}{l}\text { DT: } \\
\text { "São verbos que } \\
\text { introduzem frases } \\
\text { nominais (sujeito e } \\
\text { predicativo), levam } \\
\text { o sujeito para o caso } \\
\text { nominativo (...) e o } \\
\text { predicativo para o } \\
\text { caso acusativo (...)." }\end{array}$ & $\begin{array}{l}\text { DT: } \\
\text { "Chamam defectivos } \\
\text { os verbos a que faltam } \\
\text { algumas formas do } \\
\text { paradigma." }\end{array}$ & $\begin{array}{l}\text { DT: } \\
\text { "Estes verbos, que } \\
\text { jamais exprimem } \\
\text { ação, denominam-se } \\
\text { 'verbos de ligação' } \\
\text { (também conhecidos } \\
\text { comor 'verbos } \\
\text { copulativos' ou } \\
\text { 'verbos } \\
\text { predicativos'), mas } \\
\text { em alguns pontos se } \\
\text { assemelham aos } \\
\text { verbos auxiliares: } \\
\text { formam um conjunto } \\
\text { limitado de elementos } \\
\text { e indicam } \\
\text { basicamente } \\
\text { diferenças aspectuais } \\
\text { no sentido de } \\
\text { 'conceptualização do } \\
\text { estado e coisas'." }\end{array}$ & $\begin{array}{ll}\text { TL: } & \\
\text { 1. } & \text { Defectivo } \\
& \text { (verbo). } \\
\text { 2. } & \text { Defective } \\
& {[g r] .}\end{array}$ \\
\hline $\begin{array}{l}\text { Ex.: } \\
\text { kāna alwaladu } \\
\text { marīdan. } \\
\text { (O menino estava } \\
\text { doente.) } \\
\text { 'așbaha alwaladu } \\
\text { marīdan. } \\
\text { (O menino ficou } \\
\text { doente.) } \\
\text { ma zälla alwaladu } \\
\text { marịdan. } \\
\text { (O menino continua } \\
\text { doente.) }\end{array}$ & $\begin{array}{l}\text { Ex.: } \\
\text { Colorir: Eu coloro* o } \\
\text { desenho. } \\
\text { Demolir: Eu demolo* } \\
\text { a casa velha. }\end{array}$ & $\begin{array}{l}\text { Ex.: } \\
\text { As águas são turvas. } \\
\text { As águas estão } \\
\text { turvas. } \\
\text { As águas ficam } \\
\text { turvas. } \\
\text { As águas continuam } \\
\text { doentes. }\end{array}$ & $\begin{aligned} \text { Fonte: } & \\
\text { 1. } & \text { Sabbagh, } \\
& 2011, \text { p. } 706 . \\
\text { 2. } & \text { Corriente, } \\
& 1991, \text { p. } 779 .\end{aligned}$ \\
\hline $\begin{array}{l}\text { Fonte: } \\
\text { Almarī, 2002, vol. } \\
\text { 2, p. } 50 .\end{array}$ & $\begin{array}{l}\text { Fonte: } \\
\text { Azeredo, 2010, p. } 183 .\end{array}$ & $\begin{array}{l}\text { Fonte: } \\
\text { Azeredo, 2010, p. } \\
213 .\end{array}$ & \\
\hline
\end{tabular}




\begin{tabular}{|c|c|c|c|c|c|}
\hline $\mathbf{P t}_{1774}$ & $\begin{array}{l}\text { Verbos } \\
\text { deficiente }\end{array}$ & $\mathbf{E s}_{1992}$ & $\begin{array}{l}\text { Verbos } \\
\text { modificadores }\end{array}$ & Voc $_{1908}$ & $\begin{array}{l}\text { Verbes } \\
\text { incomplets } \\
\text { ( كان et ses } \\
\text { analogues) }\end{array}$ \\
\hline $\mathbf{P t}_{2007}$ & $\begin{array}{l}\text { As "irmãs" } \\
\text { de kāna }\end{array}$ & $\mathrm{Fr}_{1911}$ & $\begin{array}{l}\text { Verbes } \\
\text { d'existence } \\
\text { (كان et ses } \\
\text { analogues) }\end{array}$ & Dic $_{1973}$ & $\begin{array}{l}\text { Incomplete, } \\
\text { defective or } \\
\text { relative } \\
\text { kāna }\end{array}$ \\
\hline $\mathrm{In}_{1862}$ & $\begin{array}{l}\text { Incomplete, } \\
\text { defective or } \\
\text { relative } \\
\text { kāna }\end{array}$ & $\operatorname{In}_{1965}$ & $\begin{array}{l}\text { The verb كان } \\
\text { kāna and its } \\
\text { sisters }\end{array}$ & Dic $_{1983}$ & $\begin{array}{l}\text { Defective } \\
\text { verbs }\end{array}$ \\
\hline $\mathbf{I n}_{2005}$ & $\begin{array}{l}\text { Defective } \\
\text { verbs }\end{array}$ & & & & \\
\hline
\end{tabular}

O termo nāqiṣ é polissêmico em árabe, pois pode referir-se tanto à constituição morfológica de certos verbos, quanto à função de outros verbos. El-Dahahạ (1997, p. 346), autor de A Pocket Dictionary of Arabic Grammatical Nomenclature, registra ambas as acepções.

A terminologia relacionada à morfologia foi tratada quando da análise dos verbos aṣ-șahīh e almuctal, na seção 1.2.3. Decidiu-se, nesta dissertação, designar o verbo nāqis por meio da terminologia "verbos com و ou como $3^{\text {a }}$ radical" ao invés de seguir a tendência dos gramáticos não árabes em chamá-lo de "verbo defectivo".

O termo أَفْعال ناقصة 'afcāl nāqiṣa, ou os verbos nāqiṣa ${ }^{124}$ refere-se a um grupo delimitado de verbos que se diferencia dos demais da língua porque não possuem a capacidade de referenciar um acontecimento, uma ação, restando-lhe como única função referenciar o tempo. Por este motivo que, segundo Alhatīb \& Jațal (1992, p. 91), tais verbos introduzem as frases nominais, pois estas não contêm a marcação de temporalidade, sendo responsáveis apenas pela descrição do sujeito por meio do

\footnotetext{
${ }^{124} \mathrm{O}$ termo nāqișa constitui o plural de nāqiș, quando este é utilizada como adjetivo de fil (verbo) diz-se fì nāqiș, no singular, e 'afäl nāqișa, no plural.
} 
predicativo, assim como ocorre nas sentenças predicativas portuguesas, cujo verbo é o de ligação.

Corriente (1992, p. 227) afirma que além do traço temporal, estes verbos acrescentam à oração um matiz semântico de índole aspectual. Observe os exemplos abaixo:

(31) kāna alwaladu marīdan.

O menino estava doente. (atributo adquirido)

(32) 'așbaḥa alwaladu marīdan.

O menino ficou doente. (atributo resultativo)

(33) ma zäla alwaladu marīdan.

O menino continua doente. (atributo persistente)

Nos três exemplos acima, traços aspectuais diferentes foram acrescidos às sentenças na medida em que os verbos nāqișa (em negrito) foram substituídos.

Ao introduzir as frases nominais, os verbos nāqișa modificam a declinação do predicativo, que originalmente deve estar no nominativo, passa a acusativo. Eis a principal função deste grupo de verbos no âmbito sintático.

Verifica-se que gramáticos árabes e não árabes empregam esta característica sintática como definição destes verbos. Considera-se, portanto, inadequado tal posicionamento, pois a alteração do caso nominativo para o acusativo do constituinte predicativo é uma consequência da inserção dos verbos nāqișa na frase nominal e não a característica essencial dos mesmos.

O lexema nāqiș pode ser traduzido por "deficiente, falho, imperfeito, incompleto" (Sabbagh, 2010, p. 706). Estes verbos são assim chamados, na teoria gramatical, por dois motivos, primeiro por não serem capazes de referenciar o fato e, segundo, pela incompletude de seu significado, ou seja, eles necessitam do predicativo para que seu sentido na frase seja completo (Almacrī, 2002, p. 40).

Neste sentido, os gramáticos árabes seccionam estes verbos em três grupos: 
a) Aqueles que se conjugam no presente do indicativo, no pretérito perfeito e no imperativo ${ }^{125}$. São eles: كانَ kāna (ser/estar), أَصْبَحَ 'aṣbaha (amanhecer ${ }^{126}$; tornar-se, vir a ser; ficar), أَمْنَىى 'amsā (anoitecer; ficar;

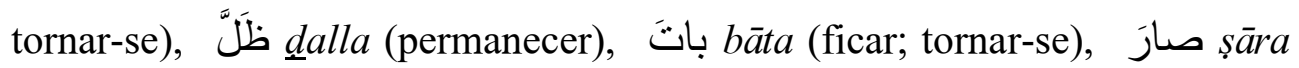
(ficar; tornar-se).

b) Aqueles que se conjugam apenas no presente do indicativo e no pretérito perfeito $^{127}$. São eles: ما زالَ mā zāla (continuar, permancer), ما بَرِحَ $m \bar{a}$

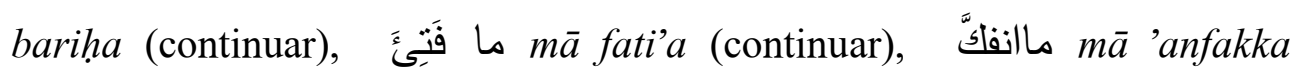
(continuar).

c) Aqueles chamados de جامِدة jāmida ou inflexíveis, porque são conjugados somente no pretérito perfeito, são eles: لَبَسنَ $\operatorname{lin}^{128}$ (não ser/não estar), دامَ $m \bar{a}$ dāma (continuar, durar).

Devido à semelhança no comportamento sintático destes verbos, são também conhecidos na teoria gramatical árabe pelo sintagma terminológico أَخَوات كانَ 'ahawāt kāna, "as irmãs de kāna", literalmente.

Certos verbos nāqișa podem funcionar como verbos auxiliares, o verbo kāna é o exponencial, pois correntemente participa da formação dos tempos compostos. A forma verbal árabe correspondente ao pretérito imperfeito do indicativo português é formada pelo verbo kāna no pretérito perfeito seguido pelo presente do indicativo do verbo principal, como em:

(34) kuntu 'aqra'u kațīran țiwāl tụfūlatī.

\footnotetext{
${ }^{125}$ Chamados de نَامَّة النَّصَرُّف tāmma at-tașarruf ou "conjugação completa”.

${ }^{126}$ A acepção "amanhecer" do verbo 'aṣbaḥa e "anoitecer" de 'amsā refere-se à mudança de estado que o indivíduo pode sofrer durante a noite até a manhã e durante o dia até a noite, respectivamente, contudo, este significado caiu em desuso, conforme Cowan (2007, p. 174) afirma em nota, sendo mais utilizado com o sentido indicado acima.

${ }^{127}$ Chamados de ناقصة النَّصَرُْف nāqisa at-tașarruf ou "conjugação incompleta".

${ }^{128}$ Embora o verbo laysa siga apenas o paradigma do pretérito perfeito, semanticamente denota o presente do indicativo, sendo traduzido por "não ser, não estar".
} 
Eu costumava ler muito ao longo da minha infância.

Se o verbo principal após kāna estiver conjugado no pretérito perfeito, como em (35), a construção expressa uma ação passada acabada, anterior a outra ação também passada, que corresponde ao pretérito mais-que-perfeito (simples/composto) da língua portuguesa.

(35) kāna qad wașala as-safîru masǟ aljumacati.

O embaixador tinha chegado sexta a noite.

De acordo com Ryding (2005, p. 636) os verbos mā zāla e șāra também podem ser usados como verbos auxiliares, o primeiro com o sentido de continuidade e o segundo denotando o início de ação do verbo principal ou sua continuação. Ambos devem ser seguidos pelo presente do indicativo do verbo principal.

Após analisar a ficha terminológica apresentada acima, observa-se que, à primeira vista, o termo árabe 'afcāl nāqișa nada tem em comum com os termos portugueses "verbo defectivo" e "verbo de ligação". As definições terminológicas do termo principal e dos possíveis correspondentes em língua portuguesa não mostram nenhuma interseção sêmica, porém, se forem consideradas as explicações acerca dos verbos nāqiṣa aqui delineadas, serão evidenciados aspectos semelhantes tanto com os "verbos defectivos" quanto com os "verbos de ligação", os quais se encontram resumidos a seguir, na tabela 9 : 


\begin{tabular}{|c|c|c|}
\hline \multicolumn{3}{|c|}{ Semelhanças } \\
\hline 'af'āl nāqișa & Verbo defectivo & Verbo de ligação \\
\hline Não exprimem ação & --- & Jamais exprimem ação \\
\hline $\begin{array}{l}\text { Introduzem frases nominais } \\
\text { (sujeito+predicativo) }\end{array}$ & --- & $\begin{array}{l}\text { Participam de sentenças } \\
\text { predicativas, unem o sujeito a } \\
\text { seu atributo (predicativo) }\end{array}$ \\
\hline Indicam diferenças aspectuais & --- & Indicam diferenças aspectuais \\
\hline $\begin{array}{c}\text { Podem atuar como verbos } \\
\text { auxiliares }\end{array}$ & --- & $\begin{array}{c}\text { Assemelham-se aos verbos } \\
\text { auxiliares }\end{array}$ \\
\hline $\begin{array}{l}\text { Falta a significação completa, } \\
\text { necessitando do predicativo }\end{array}$ & $\begin{array}{l}\text { Falta a forma de } 1^{\text {a }} \text { pessoa do } \\
\text { singular do presente do } \\
\text { indicativo }\end{array}$ & --- \\
\hline $\begin{array}{c}\text { Falta a conjugação do } \\
\text { imperativo e/ou do presente } \\
\text { do indicativo }\end{array}$ & $\begin{array}{c}\text { Falta o subjuntivo presente e } \\
\text { a } 2^{\mathrm{a}} \text { pessoa singular do } \\
\text { imperativo }\end{array}$ & \\
\hline
\end{tabular}

Tabela 9: Semelhanças entre 'afăl nāqișa, verbo defectivo e verbo de ligação

Percebe-se que o termo 'afcāl nāqișa compartilha mais semelhanças com o "verbo de ligação" do que com o "verbo defectivo", no entanto, os termos defectivel "defeituoso", designando os verbos nāqișa, figuram 50\% das obras pesquisadas, além dos dicionários que registram tal acepção para o campo linguístico. Acredita-se que a correspondência 'af'āl nāqișa e defective verbs tenha-se originado da tradução literal do verbete $n \bar{a} q i s$, que admite este sentido.

$\mathrm{Na}$ língua portuguesa, não se verifica uma correspondência entre os verbos nāqișa e os defectivos, a única semelhança é que, ao primeiro, falta uma significação completa e, ao segundo, a forma de $1^{\text {a }}$ pessoa singular do presente do indicativo. Por essa razão, desaconselha-se empregar o termo "defectivo" para denominar, em português, os verbos em estudo.

Os verbos nāqișa e os de ligação (ou predicativos) compartilham aspectos importantes que justificariam sua adoção na tarefa de designar estes verbos árabes, todavia há diferenças profundas no funcionamento destes dois grupos de verbos. Os verbos $n \bar{a} q i s \underline{\text { a }}$, ao introduzirem frases nominais, modificam a declinação do predicativo e até mesmo sua terminologia, que passa a ser chamado de habar kāna ("o predicativo de kāna), por exemplo. Esta é a característica sintática mais importante de todos os verbos nāqișa. Tal processo não acontece com os verbos de ligação, até porque não há diferenciação de casos em português. Assim, descarta-se, também, o termo "verbo de

\footnotetext{
${ }^{129}$ Mattoso Câmara (1981, p. 90) explica que "a inexistência da flexão é uma questão de desuso, o que faz essa flexão ser abolida da norma linguística e ser considerada contrária à eufonia.”
} 
ligação", a fim de evitar mal entendidos que prejudiquem a apreensão deste item gramatical árabe por parte do estudante brasileiro.

Corriente (1992, p. 227) optou por incluí-los nos chamados verbos modificadores, porque modificam o sintagma verbal, acrescentando à predicação certas nuances semânticas de traços temporais e aspectuais. Neste grupo, ele reuniu não apenas o verbo kāna e seus semelhantes (quanto ao comportamento sintático), mas também os verbos por ele chamados de incoativos e de possibilidade, os quais não correspondem aos verbos nāqișa.

Périer (1911, p. 195), Machuel (1908, p. 60), Haywood \& Nahmad (1965, p. 274) e Cowan (2007, p.173) optaram pelo emprego do sintagma terminológico أَخَوات كانَ 'ahawāt kāna, "as irmãs de kāna”, adaptado às suas línguas de chegada. Périer e Machuel optaram por utilizar o lexema analogues ao invés de "irmãs" em francês.

Como não foi evidenciada uma correspondência direta entre os termos árabe 'afcāl nāqișa e os portugueses "verbo defectivo" e "verbo de ligação", acredita-se que seja mais coerente seguir a orientação de quatro dentre os dez autores supracitados e adotar, em português, o sintagma terminológico verbo kāna e seus semelhantes para designar o termo árabe em questão. Acredita-se que esta será uma terminologia aparente ao leitor especializado que buscar tal informação. 


\title{
8. alfil almujarrad wa almazìd
}

Ao estudar os termos árabes المَجَرَّبد almujarrad almaild, que se referem à formação dos verbos, observou-se que, da teoria gramatical que os envolve, revelamse características morfológicas semelhantes aos da língua portuguesa. Tais semelhanças podem ser explicadas sob a ótica da corrente linguística gerativa. Neste sentido, Katamba (1994, p. 9) afirma que

\begin{abstract}
"Reconhecidamente, as línguas diferem entre si, mas as diferenças estruturais entre elas ocorrem dentro de um limite bastante estreito, sancionado pela Gramática Universal ${ }^{130}$. (...) no que diz respeito à formação de palavras, princípios de construção muito similares são recorrentes nas línguas. A faculdade linguística da mente é essencialmente a mesma em todos os seres humanos. Por isso que as línguas podem diferir umas das outras dentro de limites predeterminados pela neurologia e fisiologia do cérebro humano, que determina a natureza da Gramática Universal." ${ }^{\text {131 }}$ (Tradução nossa)
\end{abstract}

Katamba prossegue explicando que a diferença entre as gramáticas adquiridas por falantes do inglês e do árabe, por exemplo, pode ser atribuída à experiência individual, isto é, à realidade linguística a que cada criança é submetida. Esta seleciona a gramática específica de uma língua determinada, que varia dentro do limite previsto pela Gramática Universal.

Isto sugere, então, que as línguas naturais compartilham características estruturais que permitem ao pesquisador estabelecer paralelos teóricos que auxiliam a descrição linguística e sua análise contrastiva. Sendo assim, verificou-se a importância de delimitar conceitos árabes e portugueses presentes na gramática de ambas as línguas e pertinentes ao estudo dos dois termos árabes em questão. Os conceitos a serem delimitados são raiz, radical e afixo. A partir deste ponto, será possível estabelecer os

\footnotetext{
${ }^{130}$ De acordo com Chomsky, a Gramática Universal é a faculdade da mente que determina a natureza tanto da aquisição linguística em uma criança e quanto da competência linguística. (Katamba, 1994, p. 8) 131 "Admittedly, languages differ from each other, but the structural differences between them occur within the fairly narrow range sanctioned by Universal Grammar. (...) with regard to word-formation, very similar word-building principles recur in languages after languages. The language faculty of the mind is essentially the same in all humans. Hence languages can only differ from each other within the limits predetermined by neurology and physiology of human brain, which determine the nature of Universal Grammar."
} 
paralelos necessários à análise terminológica e padronização de ambos termos árabes em língua portuguesa.

Katamba (1994, p. 41) define raiz como "o núcleo irredutível de uma palavra $^{132}$, com absolutamente nada mais a ele ligado". Trata-se da parte sempre presente, mas com possíveis modificações, nas várias manifestações de um lexema ${ }^{133}$. Como exemplo, apresenta-se o lexema português AMAR que possui como raiz am- e encontra-se presente nos vocábulos ${ }^{134}$ "amarei", "amante", “amados", "amador". Azeredo (2010, p. 143) compartiha da visão acima e define "raiz" como sendo o morfema ${ }^{135}$ que serve de base mórfica da palavra e que responde por seu núcleo semântico.

As definições propostas por Mattoso Câmara (1981, p. 205) e Lima (2002, p. 193) não destoam das citadas acima, contudo, ambos os autores acrescentam que, ao lado do conceito sincrônico de raiz já mencionado, há o conceito diacrônico da gramática histórica indo-europeia. Segundo Mattoso Câmara, gramática histórica define raiz como o segmento fônico originário correspondente a um morfema indoeuropeu. Com a evolução das línguas indo-europeias, no entanto, as raízes genuínas desfizeram-se ou modificaram-se sensivelmente, incorporando elementos mórficos distintos. Por exemplo, o lexema português COMER já não apresenta mais a raiz indoeuropeia $-e d$, que aparece no latim comedere. Sincronicamente, a raiz portuguesa é com-, que corresponde diacronicamente ao prefixo latino. Por isso, Mattoso conclui que importa ao estudo do português apenas o conceito sincrônico de raiz.

Lima (2002, p. 193) considera que, para efeitos da análise elementar da estrutura das palavras em português, não se busca ascender à determinação das raízes, parte-se geralmente do radical, definido pelo mesmo gramático como "o morfema que funciona como o segmento lexical da palavra, opondo-se ao segmento que lhe assinala (por meio de outros morfemas) as flexões e a derivação.” De acordo com Katamba (1994, p. 45), o radical é a parte da palavra que ocorre antes de qualquer afixo flexional/ derivacional ser a ele adicionado, como, por exemplo, pedrinha, em que [pedr-]

\footnotetext{
132 "Unidade autônoma constituída de um ou vários morfemas." (Azeredo, 2010, p. 143)

${ }^{133}$ Lexema é o item lexical abstrato listado no dicionário, como, por exemplo, LER. As formas "leu", "lia", "lerei” são as manifestações textuais concretas do lexema LER. (Katamba, 1994, p. 18)

${ }^{134}$ Vocábulo designa as diferentes formas que um lexema ou palavra gramatical pode assumir no texto, em virtude de sua especificação morfossintática. (Azeredo, 2010, p. 142)

${ }_{135}$ Katamba $(1994$, p. 20$)$ esclarece que o termo "morfema" é usado para indicar a menor unidade indivisível com conteúdo semântico ou função gramatical com a qual as palavras são formadas.
} 
representa o radical (e a raiz) deste lexema e [-inha] é o morfema derivacional que indica diminutivo. Ao contrário do exemplo acima, há vocábulos em que a raiz e o radical não são coincidentes. Em cantarolar, por exemplo, a raiz é [cant-] e o radical é [cantarol-].

Quanto aos afixos ou morfemas derivacionais, Azeredo (2010, p. 143) explica que estes "juntam-se a bases léxicas (morfemas lexicais) para a criação de novos lexemas". Em português, há dois tipos de afixos, os prefixos, que são aqueles inseridos antes do radical, e os sufixos, aqueles que se inserem após o radical, como em transformar e felicidade, respectivamente.

A perspectiva da análise morfológica árabe difere das propostas teóricas contemporâneas, o que, a princípio, inviabilizaria um paralelo estrito entre conceitos árabes e portugueses. Ryding (2005, p. 44) explica que em fins do século VIII e início do IX d.C., os primeiros gramáticos árabes desenvolveram teorias morfológicas sofisticadas que divergem das teorias linguísticas ocidentais, entretanto, como este trabalho destina-se, em primeiro lugar, aos leitores especialistas brasileiros, optou-se por seguir a linha de análise da linguística ocidental, sem perder o ponto de vista árabe.

A جُر , A teoria gramatical árabe-árabe emprega dois termos distintos, a saber, jidr ou laṣl, a fim de designar o conceito de raiz. Como mencionado anteriormente na seção 1., a grande maioria dos verbos árabes possui raiz triconsonantal, porém as quadriconsonânticas não são de rara existência (Wright, 1859, p. 27). Ao lado destas, Ryding $\left(2005\right.$, p. 47) inclui as raízes com cinco consoantes ${ }^{136}$, fruto de empréstimos linguísticos recentes. Lipiński (1997, p. 201) salienta que a presença das raízes biconsonantais nas línguas semíticas não pode ser negada, há no Árabe Moderno Padrão uma quantidade reduzida de palavras bilíteras as quais só podem ser explicadas à luz de uma investigação diacrônica. Sendo assim, serão consideradas nesta pesquisa apenas as raízes constituídas por três ou quatro consoantes.

$\mathrm{Na}$ visão árabe, a raiz de um verbo derivado, por exemplo, corresponde à origem tri ou quadriconsonantal do mesmo. Para se descobrir a essência do verbo, é

\footnotetext{
${ }^{136}$ Há, na língua, raízes quadriconsonantais genuínas, fruto de reduplicação de raízes bilíteras, como $w-s-$ $w-s$ e $h-m-h-m$. Há também aquelas raízes de quatro e cinco consoantes que entraram na língua árabe por meio de empréstimos recentes, como a raiz $t-l-f-n$ que dá o verbo telefonar e $b-r-n-m-j$, que dá o verbo programar. (Ryding, 2005, p. 47)
} 
preciso desnudá-lo, retirando todos os morfemas derivacionais e flexionais que o compõem. Tais morfemas representam as أَحْرُف الزّبِادة 'aḥruf azziyāda, as "letras de acréscimo"137, em tradução literal, responsáveis pela derivação e/ou flexão do verbo.

Segundo Lipiński (1997, p. 201), a maioria das palavras das línguas semíticas é analisada como sendo uma combinação de três consoantes e uma ou mais vogais. Esta concepção foi fortemente defendida no século X, por Hayyudj de Fez, cujas ideias são comumente seguidas até hoje. De acordo com esta análise tradicional, as três consoantes, chamadas de radicais, formam a menor unidade lexical da língua e constituem a sua raiz. Assume-se que este elemento semântico básico seja especificado a partir do momento que as 'aḥruf azziyāda, "letras de acréscimo", são acrescidas a ele. Assim, as "letras de acréscimo" ou restringem o significado da raiz, servindo como morfema lexical, como em kitāb (livro), ou determinam sua categoria gramatical, atuando como morfema gramatical ${ }^{138}$, como em kataba (ele escreveu).

A raiz árabe $k-t-b$, por exemplo, carrega o sentido abstrato relacionado à "escrita". Todos os verbos ou nomes dela derivados estarão dentro deste campo semântico. Observe abaixo:

\begin{tabular}{|c|c|}
\hline RAIZ abstrata - "escrita" & 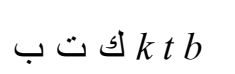 \\
\hline $\begin{array}{l}\text { Escrever (ele escreveu) }{ }^{139} \text { - a forma verbal mais } \\
\text { próxima à raiz }\end{array}$ & كَataba \\
\hline Manter correspondência, escrever a & كاتَبَ kātaba \\
\hline Fazer escrever, ditar & أَكْنَبَ \\
\hline Inscrever-se, registrar-se & إِكْنَبَ 'iktataba \\
\hline Escritor & كاتِب kātib \\
\hline Livro & Kitāa \\
\hline
\end{tabular}

\footnotetext{
${ }^{137}$ Há uma técnica tradicional árabe utilizada para memorização das "letras de acréscimo", trata-se da سَأُلنمونيها sa'altumūnīhā ("vocês me perguntaram isto"), que reúne todos os itens capazes de alterar a morfologia de raízes, por meio do mecanismo de derivação ou flexão. Os morfemas derivacionais e

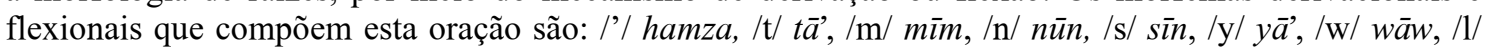
lam, /h/ hä, as vogais breve /a/, /u/ e /i/, as vogais longas $/ \overline{\mathrm{a}} /, / \overline{\mathrm{u}} / \mathrm{e} / \overline{\mathbf{1}} /$, e o diacrítico $\check{s} a d d a / \check{\omega} /$, que indica duplicação de consoante.

${ }^{138}$ Azeredo (2010, p. 143) explica que os morfemas pertencem a duas ordens principais: morfema lexical, aquele que serve de base/radical de um lexema, e morfema gramatical, aquele que pode ser base de uma palavra gramatical (outr-o, minh-a, el-a) ou ocupar posição periférica (en-capuz-ar, feli-cidade).

${ }^{139}$ Como não há infinitivo em árabe, considera-se a forma mais próxima à raiz como se fosse o infinitivo, contudo, se traduzida literalmente refere-se a terceira pessoa do singular do pretérito perfeito.
} 
Lipiński (1997, p. 202) reitera que a raiz, como menor unidade lexical, seja ela bi/tri/quadriconsonantal, consiste apenas na base abstrata de uma família de palavras de uma língua, não existindo como uma realidade viva no idioma falado, devido a sua constituição se dar somente por consoantes, o que a torna impronunciável. Ao contrário do que ocorre em português, por exemplo, em que há bases mórficas - raízes, que correspondem a morfemas livres, isto é, aqueles que sozinhos constituem palavras, como em mar, feliz, capuz, capim (Azeredo, 2010, p. 143).

Ryding (2005, p. 45), representante da teoria linguística gerativa, considera que a morfologia árabe baseia-se em morfemas descontínuos interligados, expressos pela raiz consonantal e pelo paradigma ${ }^{140}$, que consiste no modelo que os vocábulos derivados seguem, sendo formado tanto pelo padrão vocálico (das vogais breves) quanto pelas 'aḥruf azziyāda ou "letras de acréscimo", conforme a ilustração abaixo:

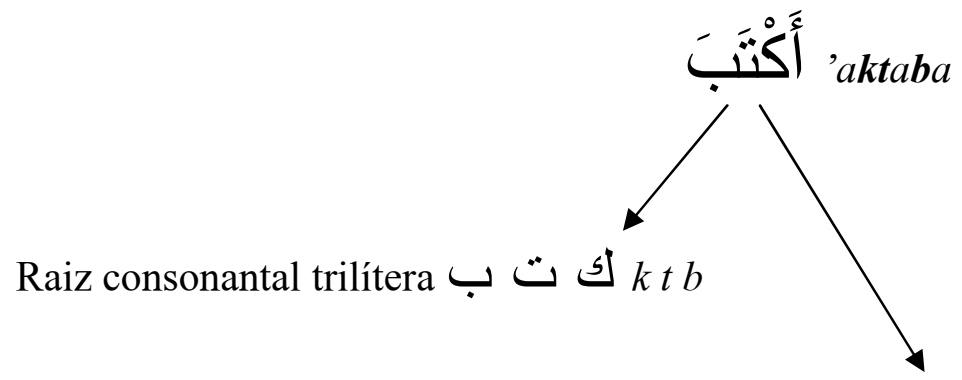

Paradigma verbal da forma IV (' $\left.a_{-}{ }_{-}{ }_{-} a\right)^{141}$ que veicula, por excelência, os conceitos factitivo e causativo (Gomes, 2011, p. 64)

Para Ryding (2005, p. 47-48), a raiz árabe consiste em um morfema preso porque não pode ocorrer isoladamente, visto ser composta apenas por consonante o que a torna impronunciável, e descontínuo - por aceitar inserções internas. Trata-se do núcleo semântico ao redor do qual uma ampla possibilidade de vocábulos pode ser derivada, de acordo com o paradigma no qual for inserido. Como foi dito acima, o paradigma é também um morfema preso e descontínuo, constituído por uma ou mais

\footnotetext{
${ }^{140}$ É costume encontrar nas análises linguísticas sobre a língua árabe a afirmação de que os morfemas descontínuos consistem na raiz consonantal e no padrão vocálico, como se verifica em Schramm (1962, pp. 360-375). Preferiu-se utilizar o termo "paradigma" ao invés de "padrão vocálico", nesta dissertação, porque há consoantes que participam da formação destes padrões ou modelos os quais serão interligados com as raízes consonantais.

${ }^{141}$ Gomes $(2011$, p. 61) afirma que os paradigmas de derivação verbal foram formulados por gramáticos árabes dos séculos VII e VIII d.C. e chamados por eles de وَزَّ wazn - "métrica, padrão". Os arabistas convencionaram chamá-los de formas numeradas por algarismos romanos I a XV. Cada espaço em branco marcado pelo símbolo underline (\lrcorner ) representa o local onde as consoantes radicais serão colocadas.
} 
vogais e certas consoantes, as "letras de acréscimo", e as posições fixas que receberão as consoantes radicais da raiz, as quais são chamadas na teoria gerativa de slots (do inglês "espaço"). O paradigma geralmente possui significado gramatical, como, por exemplo, em kātib - escritor, cujo paradigma _ $\bar{a}_{-} i_{-}$representa o agentivo do verbo.

$\mathrm{Na}$ teoria gramatical árabe descrita por ocidentais, o termo radical refere-se a cada consoante que compõe a raiz, seja ela bi, tri ou quadriconsonantal (Cowan, 2007, p. 63) e (Lipiński, 1997, p. 202). Verifica-se, então, que a definição árabe para o termo radical diverge da mesma proposta para o termo português, caracterizando-se assim uma situação de polissemia.

Os afixos ou morfemas derivacionais representam as 'ahruf azziyāda - as "letras de acréscimo", na tradição árabe. Tais consoantes e vogais (breves e longas) podem, de acordo com o paradigma, ocorrer antes, dentro ou depois da raiz, constituindo o prefixo, o infixo e o sufixo, respectivamente. Katamba (1994, p. 44) afirma que o infixo é um morfema característico das línguas semíticas, como o árabe e o hebraico, por exemplo.

Após a explanação acerca dos três conceitos selecionados, observe a tabela contrastiva abaixo:

\begin{tabular}{|l|c|c|c|}
\cline { 2 - 4 } \multicolumn{1}{c|}{} & RAIZ & RADICAL & AFIXO \\
\hline Língua Árabe & $\begin{array}{c}\text { Menor unidade } \\
\text { lexical, composta } \\
\text { por três ou quatro } \\
\text { consoantes }\end{array}$ & $\begin{array}{c}\text { Cada consoante que } \\
\text { compõe a raiz }\end{array}$ & $\begin{array}{c}\text { Prefixo, infixo e } \\
\text { sufixo }\end{array}$ \\
\hline Língua Portuguesa & $\begin{array}{c}\text { Núcleo não } \\
\text { segmentável de uma } \\
\text { palavra }\end{array}$ & $\begin{array}{c}\text { Morfema lexical ao } \\
\text { qual se ligam } \\
\text { morfemas } \\
\text { derivacionais ou } \\
\text { flexionais. Também } \\
\text { é chamado de base }\end{array}$ & Prefixo e sufixo \\
\hline
\end{tabular}

Tabela 10: Raiz, radical e afixo em árabe e português 


\section{1 - mujarrad}

\begin{tabular}{|c|c|c|c|c|c|}
\hline & Termo & \multicolumn{2}{|c|}{$\begin{array}{c}\text { Possível correspondência } \\
\text { em Pt }\end{array}$} & \multicolumn{2}{|c|}{ Proposta de padronização } \\
\hline \multicolumn{2}{|c|}{ mujarrad دُجَرَّد } & \multicolumn{2}{|c|}{ Raiz } & \multicolumn{2}{|r|}{ Primitivo } \\
\hline \multicolumn{2}{|c|}{$\begin{array}{l}\text { DT: } \\
\text { "São aqueles [verbos] cujas } \\
\text { consoantes são primitivas e } \\
\text { não se soma à raiz letra } \\
\text { alguma. São divididos em } \\
\text { mujarrad trilítero e mujarrad } \\
\text { quadrilítero." } 142\end{array}$} & \multicolumn{2}{|c|}{$\begin{array}{l}\text { DT: } \\
\text { "Raiz é o morfema originário } \\
\text { e irredutível que contém o } \\
\text { núcleo significativo comum a } \\
\text { uma família linguística }{ }^{143} \text {." }\end{array}$} & \multicolumn{2}{|c|}{ 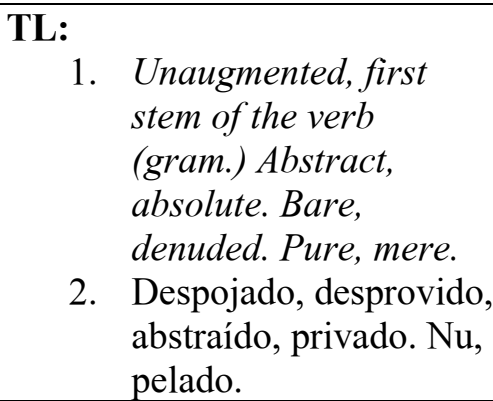 } \\
\hline \multicolumn{2}{|c|}{$\begin{array}{l}\text { Ex.: } \\
\text { kataba (escrever) } \\
\text { darasa (estudar) } \\
\text { tarjama (traduzir) }\end{array}$} & \multicolumn{2}{|c|}{$\begin{array}{ll}\text { Ex.: } & \\
\text { pedri-inha } & \text { pur- } a \\
\text { pedr-ada } & \text { pur-íssima } \\
a \text {-pedr-ejar } & \text { de-pur- } a r\end{array}$} & \multicolumn{2}{|c|}{$\begin{aligned} \text { Fonte: } & \\
\text { 1. } & \text { Al-Mawrid, 1995, p. } \\
& 978 . \\
\text { 2. } & \text { Sabbagh, 2011, p. } 606 .\end{aligned}$} \\
\hline \multicolumn{2}{|c|}{$\begin{array}{l}\text { Fonte: } \\
\text { Almarī, 2002, vol. 10, p. } 18 .\end{array}$} & \multicolumn{2}{|c|}{$\begin{array}{l}\text { Fonte: } \\
\text { Lima, 2002, p. } 193 .\end{array}$} & & \\
\hline $\mathbf{P t}_{1774}$ & $\begin{array}{l}\text { Simples e nu } \\
\text { Primitivo }\end{array}$ & $\mathbf{E s}_{1992}$ & $\begin{array}{l}\text { Raíz } \\
\text { triconsonántical } \\
\text { cuadriconsonántica } \\
\text { simples }\end{array}$ & Voc $_{1908}$ & Primitif(verbe) \\
\hline $\mathbf{P t}_{2007}$ & $\begin{array}{l}\text { Simples de três ou } \\
\text { quatro radicais }\end{array}$ & $\mathbf{F r}_{1911}$ & Primitif & Dic $_{1973}$ & Unaugmented \\
\hline $\operatorname{In}_{1859}$ & $\begin{array}{l}\text { Ground form } \\
\text { Form I }\end{array}$ & $\operatorname{In}_{1965}$ & $\begin{array}{l}\text { Simple } \\
\text { Root form of the } \\
\text { verb }\end{array}$ & Dic $_{1983}$ & Abstract \\
\hline $\mathbf{I n}_{2005}$ & $\begin{array}{l}\text { Base form } \\
\text { Form I } \\
\text { Stripped } \\
\end{array}$ & & & & \\
\hline
\end{tabular}

Literalmente traduzido por "nu", "desprovido", "simples", “abstrato", o termo árabe mujarrad representa a forma verbal morfologicamente mais simples (Ryding, 2005, p. 434), isto é, a mais próxima à raiz consonantal de três ou quatro letras.

Ao cotejarem-se as definições terminológicas apresentadas, verifica-se que não há semas em comum que sugira a padronização deste termo árabe pelo termo português

\footnotetext{
142 Tradução nossa de: المجرَّد ما كانت حروفه أصلية ولم يُزَزْ عليها حرفٍ ويقسّم إلى المجرّد الثناثي، والمجرّد " (almujarrad mā kānat hurūfahu 'așliya walam yujad calayhā harfin wayuqassimu 'ilà

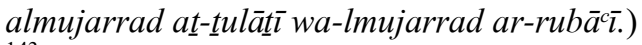

143 "Pertencem à mesma família as palavras que possuem o mesmo radical, que, às vezes, coincide com a raiz." (Lima, 2002, p. 215)
} 
"raiz". Viu-se acima que o conceito de raiz em ambas as línguas são semelhantes na medida em que contém a significação lexical de determinado grupo de palavras, entretanto, em português, a raiz consiste em uma unidade não segmentável, já em árabe, este núcleo significativo pode ser intercalado por outro morfema, chamado de paradigma, que acrescentará novos sentidos à base mórfica original.

Dentre os sete gramáticos não árabes estudados, apenas dois deles, a saber, Haywood \& Nahmad (1965, p. 151) e Ryding (2005, p. 434) dissertaram sobre o termo mujarrad, tecendo considerações interessantes sobre ele e sua contraparte, o verbo mazìd.

O panorama terminológico presente na ficha acima permite observar que, apesar de não haver um tratamento homogêneo, todas as opções de termos apresentadas perpassaram características inerentes ao termo mujarrad. Abrantes (1774, p. 130), Haywood \& Nahmad (1965, p. 151), Corriente (1992, p. 149), Cowan (2007, p. 138) salientam a simplicidade morfológica desta forma verbal. Abrantes (1774, p. 139) emprega, também, o termo "primitivo" repetidas vezes a fim de designar a forma mais simples de determinada "conjugação derivada", em suas palavras.

Wright (1859, p. 27) e Ryding (2005, p. 434) chamam-na de forma base ou forma I, referindo-se a primeira forma das derivações verbais, isto é, àquela mais próxima à raiz verbal, seria o mesmo que dizer a forma mais simples do verbo. Esta opção é coerente com a gramática árabe, no entanto, não foi priorizada nesta dissertação devido à estratégia didática do paralelismo terminológico entre os termos.

Périer (1911, p. 15) e Machuel (1908, p. 19) empregam o termo "primitivo" para designar os verbos mujarrad, os quais de fato o são, se for considerada a definição de Mattoso Câmara (1981, p. 205) na qual afirma que o vocábulo primitivo é aquele cujo morfema lexical corresponde ao radical primário ou à raiz, em alguns casos. Por exemplo, "escrever" corresponde ao verbo árabe kataba, cujo morfema lexical e a raiz são $k-t-b$.

Cachia (1973, p. 82) registrou o termo unaugmented ou "não aumentado", isto é, esta forma verbal não é aumentada/derivada por nenhuma das "letras de acréscimo". A ideia central é esta, no entanto, "não aumentado" representa um termo opaco aos especialistas brasileiros. 
Bakalla et al. (1983, p. 88) optaram pela acepção "abstrata", um sentido possível do lexema, contudo distante da realidade linguística deste termo.

Desta forma, sugere-se que seja adotado em português o termo primitivo a fim de designar o termo árabe mujarrad, porque, além de este ser transparente ao leitor brasileiro, não remete a um conceito português conflitante com outro árabe, uma vez que primitivo, em ambas as línguas, é tudo aquilo que "coincide com sua origem" (Houaiss, 2007). 


\section{2 - mazìd}

\begin{tabular}{|c|c|c|c|c|c|}
\hline \multicolumn{2}{|r|}{ Termo } & \multicolumn{2}{|c|}{$\begin{array}{c}\text { Possível correspondência } \\
\text { em Pt }\end{array}$} & \multicolumn{2}{|c|}{ Proposta de padronização } \\
\hline \multicolumn{2}{|c|}{ mazìd } & \multicolumn{2}{|c|}{ Derivado } & \multicolumn{2}{|r|}{ Derivado } \\
\hline \multicolumn{2}{|c|}{$\begin{array}{l}\text { DT: } \\
\text { "O verbo mazīd é o verbo } \\
\text { mujarrad com a afixação de } \\
\text { uma das 'letras de } \\
\text { acréscimo' ou com a } \\
\text { duplicação de uma de suas } \\
\text { consoantes } \\
\text { originais." }\end{array}$} & \multicolumn{2}{|c|}{$\begin{array}{l}\text { DT: } \\
\text { "Por sua vez, os que provêm } \\
\text { de outras palavras se chamam } \\
\text { derivados." }\end{array}$} & \multicolumn{2}{|c|}{$\begin{array}{l}\text { TL: } \\
\text { 1. Derivado. } \\
\text { 2. Augmented. Derived } \\
\\
\text { stem of a verb. }\end{array}$} \\
\hline \multicolumn{2}{|c|}{$\begin{array}{l}\text { Ex.: } \\
\text { takātaba (corresponder-se) } \\
\text { darrasa (ensinar) }\end{array}$} & \multicolumn{2}{|c|}{$\begin{array}{l}\text { Ex.: } \\
\text { pôr - transpôr } \\
\text { ceder - exceder, preceder }\end{array}$} & \multicolumn{2}{|c|}{$\begin{aligned} \text { Fonte: } & \\
\text { 1. } & \text { Sabbagh, 2011, p. } 633 . \\
\text { 2. } & \text { Al-Mawrid, 1995, p. } \\
& 1028 .\end{aligned}$} \\
\hline \multicolumn{2}{|c|}{$\begin{array}{l}\text { Fonte: } \\
\text { Almarīi, 2002, vol. 10, p. } 18 .\end{array}$} & \multicolumn{2}{|c|}{$\begin{array}{l}\text { Fonte: } \\
\text { Azeredo, 2010, p. } 157 .\end{array}$} & & \\
\hline $\mathbf{P t}_{1774}$ & $\begin{array}{l}\text { Conjugação } \\
\text { derivada }\end{array}$ & $\mathbf{E s}_{1992}$ & $\begin{array}{l}\text { Verbo de raíz } \\
\text { triconsonántical } \\
\text { cuadriconsonántica } \\
\text { derivado }\end{array}$ & Voc $_{1908}$ & Verbe derivé \\
\hline $\mathbf{P t}_{\mathbf{2 0 0 7}}$ & Verbo derivado & $\mathbf{F r}_{1911}$ & Formé derivé & Dic $_{1973}$ & Augmented \\
\hline $\operatorname{In}_{1859}$ & Derived form & $\operatorname{In}_{1965}$ & Derived form & Dic $_{1983}$ & --- \\
\hline $\mathbf{I n}_{2005}$ & $\begin{array}{l}\text { Augmented } \\
\text { Extended verb } \\
\text { form (II-X) }\end{array}$ & & & & \\
\hline
\end{tabular}

Ao contrário do verificado em sua contraparte, a ficha terminológica do verbo mazīd apresenta homogeneidade nas escolhas dos termos. Observa-se que sete entre os dez autores optaram por qualificar o verbo mazīd com o adjetivo "derivado". Dois dentre eles, a saber, Cachia (1973, p. 11) e Ryding (2005, p. 434) chamaram-no de augmented, ou "aumentando", termo em paralelo ao proposto para o verbo mujarrad unaugmented.

Se o verbo mujarrad, ou primitivo, segundo nossa proposta de padronização, é aquele morfologicamente mais simples, o termo mazìd designa todos os verbos cuja forma é morfologicamente mais complexa (Ryding, 2005, p. 434). Tal complexidade

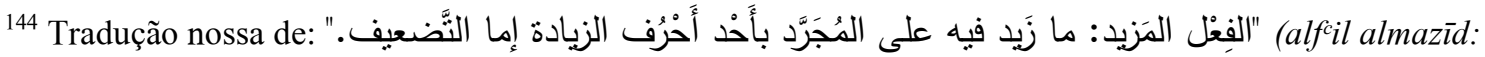
mā zayd fìhi 'alà almujarrad bi'aḥd 'ahruf azziyād 'imā at-tad'îf.)
} 
advém da afixação das 'aḥruf azziyāda, ou "letras de acréscimo", à raiz verbal, gerando verbos derivados.

As raízes trilíteras apresentam quinze paradigmas derivacionais, denominados pelos arabistas de formas (I-XV), das quais a primeira corresponde à forma primitiva e as cinco últimas são de raríssima ocorrência no Árabe Moderno Padrão (Wright, 1859, p. 27) e (Gomes, 2011, p. 59). Já as raízes quadrilíteras apresentam apenas quatro possibilidades de paradigmas derivacionais. Cada paradigma citado acrescenta novas nuances de sentido à raiz, formando novos verbos. Teoricamente, todos os paradigmas derivacionais podem ser aplicados às raízes existentes na língua, contudo, na prática, nenhuma raiz lexical conjuga-se em todas as formas (Ryding, 2005, p. 434) e (Gomes, 2011, p. 59) ${ }^{145}$.

A forma I, chamada também de forma base, por conta da simplicidade de sua estrutura, representa a forma verbal mais próxima à raiz abstrata, representanto outra maneira de designar o verbo mujarrad. A partir desta forma I, são afixados os morfemas derivacionais que constituirão os quinze paradigmas derivacionais verbais possíveis na língua árabe.

Então, se o verbo mujarrad consiste na forma base/primária/primitiva da qual os verbos mazìd são derivados, e denominou-se o termo mujarrad de "primitivo", logo se sugere que seja adotado o termo derivado a fim de designar em português o verbo mazìd. Tal proposta de padronização não se pauta apenas no silogismo acima, mas também se fundamenta em ambas as definições terminológicas apresentadas, nas quais é possível constatar coincidência de semas, mesmo a portuguesa sendo mais abrangente que a árabe.

\footnotetext{
${ }^{145}$ Para uma descrição das nuances semânticas das formas derivacionais, ver Gomes (2011).
} 
9. - 'afâl almuqāraba wa ar-rajā' wa aš-šurūc

\begin{tabular}{|c|c|c|c|c|c|}
\hline \multicolumn{2}{|r|}{ Termo } & \multicolumn{2}{|c|}{$\begin{array}{l}\text { Possível correspondência } \\
\text { em Pt }\end{array}$} & \multicolumn{2}{|c|}{ Proposta de padronização } \\
\hline \multicolumn{2}{|c|}{ 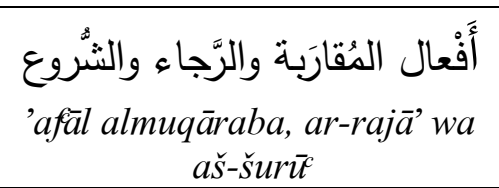 } & \multicolumn{2}{|c|}{ Verbo auxiliar } & \multicolumn{2}{|c|}{$\begin{array}{l}\text { Verbos de iminência, de } \\
\text { possibilidade e de } \\
\text { incoatividade }\end{array}$} \\
\hline \multicolumn{2}{|c|}{$\begin{array}{l}\text { DT: } \\
\text { “(...) como se este verbo fosse } \\
\text { um dos verbos semelhantes a } \\
\text { kāna, porque executam sua } \\
\text { função sintática, isto é, } \\
\text { introduzem frases nominais, } \\
\text { levando o sujeito nominal } \\
\text { para o nominativo e o } \\
\text { predicativo para } \\
\text { acusativo."146 o }\end{array}$} & \multicolumn{2}{|c|}{$\begin{array}{l}\text { DT: } \\
\text { “(...) auxiliares são os verbos } \\
\text { que precedem o verbo } \\
\text { principal com a função de } \\
\text { exprimir os conteúdos } \\
\text { gramaticais }{ }^{147} \\
\text { referidos.” }\end{array}$} & \multicolumn{2}{|c|}{$\begin{aligned} \text { TL: } & \\
\text { 1. } & \text { a. Aproximação; b. } \\
& \text { Esperança; c. Advento. } \\
\text { 2. } & \text { a. Approach; b. Hope, } \\
& \text { expectation; c. } \\
& \text { Beginning. }\end{aligned}$} \\
\hline \multicolumn{2}{|c|}{$\begin{array}{l}\text { Ex.: } \\
\text { kāda/'awšaka } \\
\text { asà } \\
\text { 'ahada/ bada'a/ šaraca }\end{array}$} & \multicolumn{2}{|c|}{$\begin{array}{l}\text { Ex.: } \\
\text { O agricultor começa a colher } \\
\text { bananas. } \\
\text { O agricultor pode colher } \\
\text { bananas. }\end{array}$} & \multicolumn{2}{|c|}{$\begin{aligned} \text { Fonte: } & \\
\text { 1. } & \text { Sabbagh, 2011, p. } \\
& 666 / 329 / 395 . \\
\text { 2. } & \text { Al-Mawrid, 1995, p. } \\
& 1.085 / 577 / 668 .\end{aligned}$} \\
\hline \multicolumn{2}{|c|}{$\begin{array}{l}\text { Fonte: } \\
\text { Almarī, 2002, vol. 2, p. } 53 .\end{array}$} & \multicolumn{2}{|c|}{$\begin{array}{l}\text { Fonte: } \\
\text { Azeredo, 2010,p. } 203 .\end{array}$} & & \\
\hline $\mathbf{P t}_{1774}$ & $\begin{array}{l}\text { Verbos de } \\
\text { vizinhança }\end{array}$ & $\mathbf{E s}_{1992}$ & $\begin{array}{l}\text { Verbos } \\
\text { modificadores }\end{array}$ & Voc $_{1908}$ & Verbe de aproximité \\
\hline $\mathbf{P t}_{2007}$ & $\begin{array}{l}\text { As “irmãs" de } \\
\text { kāna }\end{array}$ & $\mathbf{F r}_{1911}$ & Verbe de possibilité & Dic $_{1973}$ & $\begin{array}{l}\text { Verb of } \\
\text { appropinquation } \\
\text { Verb of beginning }\end{array}$ \\
\hline $\operatorname{In}_{1859 / 1862}$ & --- & $\mathbf{I n}_{1965}$ & $\begin{array}{l}\text { Verb kāda } \\
\text { Verb asà }\end{array}$ & Dic $_{1983}$ & -- \\
\hline $\mathbf{I n}_{2005}$ & --- & & & & \\
\hline
\end{tabular}

Segundo a tradição gramatical árabe, os verbos em questão são divididos em três grupos a partir de seu valor semântico. Os verbos muqāraba indicam a aproximação do acontecimento expresso pelo verbo principal. Os verbos rajā’ referem-

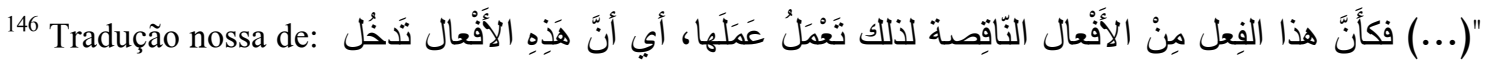
faka'anna had̄a alfit min al'afäl an-nāqisa lidalik toamalu camalahā, 'ay 'anna hadihi al'afäl tadhul calà aljumla al'ismiya fatarfau almubtada' wa yusammà 'ismuhā, wa inșubu alhabar wa yusammà habaruhā.)

${ }^{147}$ De acordo com Azeredo (2010, p. 202), os conteúdos gramaticais "abrangem as noções de tempo/modo, número/pessoa e outras duas ordens de variações: a 'estrutura interna' do processo (aspecto e desdobramentos da ação) e a 'atitude enunciativa' (modalidade)".
} 
se à expectativa da ocorrência da ação expressa pelo verbo principal. E os verbos $\breve{s} u r \bar{u} c$ designam o início de um processo expresso pelo verbo principal.

Os gramáticos consultados, a saber, Almacrī (2002, vol. 2, p. 53), Alhațīb \& Jațal (1993, p. 96) e Alhawș (1987, p. 157), concordam quanto à descrição gramatical e ao número de itens verbais classificados em cada grupo. Alhawș, no entanto, insere outros exemplos de verbos menos usados. Decidiu-se citar, nesta dissertação, apenas os mais frequentes.

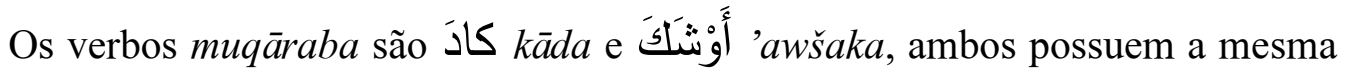
significação - "estar a ponto de, estar prestes a" (Sabbagh, 2011, p. 547/116). Podem ocorrer tanto no presente do indicativo quanto no pretérito perfeito.

O verbo rajā’ mais frequente é عَسَى asā que quer dizer “talvez, quiçá, eu espero" (Al-Mawrid, 1995, p. 761). Seu uso mais frequente se dá na $3^{\mathrm{a}}$ pessoa masculina singular do pretérito perfeito, embora remeta a uma significação do presente indicativo ou futuro (Haywood \& Nahmad, 1965, p. 269).

Alhațīb \& Jaṭal (1993, p. 96) afirmam que šurūce é todo o verbo que indica o princípio de uma ação. Consistem nos chamados verbos incoativos ou inceptivos em português. Há, contudo, exemplos predeterminados de verbos empregados nesta função e que assumem o sentido de "começar, iniciar, pôr-se a" (Sabbagh, 2011, 395), são eles,

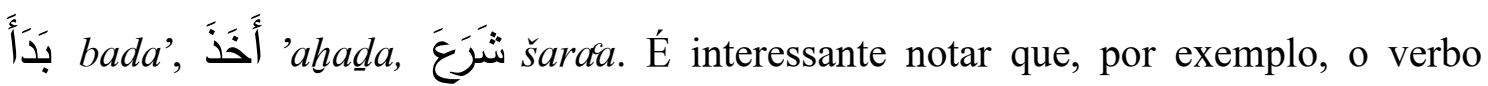
'ahada possui outro significado principal - "pegar, tomar", porém quando é utilizado nesta função, incorpora o sentido deste grupo de verbos.

E como o estudante/pesquisador reconhecerá tal uso específico? Por meio da sintaxe. Estes três grupos de verbos possuem uma sintaxe particular, já apresentada na definição terminológica proposta. Trata-se de verbos cujo comportamento sintático assemelha-se a kāna, por introduzirem frases nominais, modificando a sintaxe original do predicativo do sujeito (de nominativo passa a acusativo). Por esse motivo, alguns dos gramáticos não árabes pesquisados incluem o estudo destes verbos no capítulo reservado a kāna e seus semelhantes. 
Há, entretanto, uma diferença fundamental e determinante entre os verbos $m u q \bar{a} r a b a, r a j \bar{a}, ’ \check{s} u r \bar{u} c$ e $k \bar{a} n a$ (e seus semelhantes). Estes introduzem as frases nominais, modificando o caso do predicativo do sujeito, o qual pode ser representado por um adjetivo ou uma oração, como mostra os exemplos abaixo:

(36)

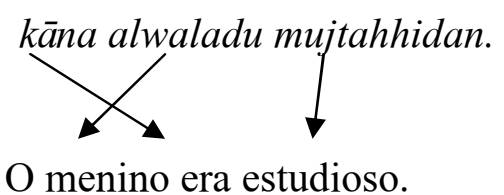

(37)

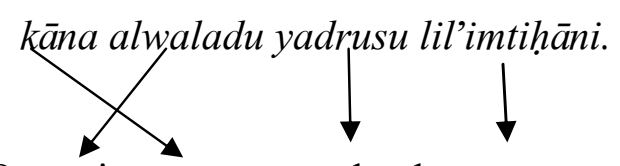

O menino estava estudando para a prova.

No primeiro exemplo, mujtahhidan representa o predicativo do sujeito que se encontra no caso acusativo. Já no segundo, o adjetivo foi substituído pela oração yadrusu, literalmente "ele estuda", que passa a ocupar o lugar sintático de acusativo.

Os verbos muqāraba, rajāa,' šurūc, da mesma forma, introduzem uma frase nominal, modificando o caso do predicativo do sujeito, contudo, sua posição sintática acusativa somente poderá ser preenchida por uma oração, como nos exemplos abaixo:

(38)

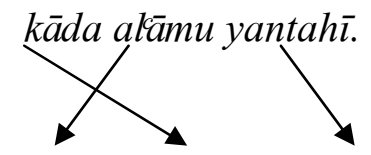

$\mathrm{O}$ ano está prestes a terminar.

(39) 'ahada attalju yanhamiru.

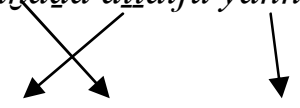

A neve começou a cair em abundância.

Em (38), a oração yantahī, literalmente "ele termina”, ocupa a posição sintática acusativa. Igualmente ocorre em (39), em que a oração yanhamiru ("ele cai em abundância") completa o sentido da oração maior iniciada pelo verbo 'ahada e ocupa a posição sintática acusativa do predicativo do sujeito. 
Outra característica importante destes verbos consiste na possibilidade/impossibilidade de virem seguidos pela conjunção أَنْ 'an. Os verbos $m u q \bar{a} r a b a$ e rajāa podem ou não vir seguidos por esta conjunção, já os verbos $\check{s} u r \bar{u}$, obrigatoriamente, não podem ser sucedidos pela mesma. A presença ou ausência desta conjunção não implica mudança de significado.

Observe a tabela 11 abaixo, em que constam os principais traços destes verbos:

\begin{tabular}{|c|c|c|c|c|}
\hline & Exemplo & Valor semântico & Tempo verbal & Conjunção ’an \\
\hline $\begin{array}{l}\text { Verbos } \\
\text { muqāraba }\end{array}$ & $\begin{array}{c}\text { kāda } \\
\text { 'awašaka }\end{array}$ & $\begin{array}{l}\text { Aproximação do } \\
\text { evento principal }\end{array}$ & $\begin{array}{c}\text { Presente do } \\
\text { indicativo ou } \\
\text { pretérito perfeito }\end{array}$ & Com ou sem \\
\hline Verbos rajā & cas $\bar{a}$ & $\begin{array}{l}\text { Expectativa do } \\
\text { evento principal }\end{array}$ & Pretérito perfeito & Com ou sem \\
\hline Verbos šurūc & $\begin{array}{l}\text { 'ahada } \\
\text { bada' } \\
\text { šaraa }\end{array}$ & $\begin{array}{l}\text { Início do evento } \\
\text { principal/incoativo }\end{array}$ & Pretérito perfeito & $\begin{array}{l}\text { Absolutamente } \\
\text { sem }\end{array}$ \\
\hline
\end{tabular}

Tabela 11: Características principais dos verbos muqāraba, rajāe šurū

Dentre os autores pesquisados, Abrantes (1774, p. 305), Périer (1911, p. 82), Haywood \& Nahmad (1965, p. 269), Corriente (1992, p. 227) e Cowan (2007, p. 173) discutem o comportamento destes verbos, ou simplesmente notificam sua existência por meio de exemplos. Verifica-se, também, que nos vocabulários/dicionários terminológicos pesquisados, dois autores apresentaram termos correspondentes somente à categoria dos verbos muqāraba.

Abrantes (1774, p. 305) reserva um parágrafo para a explicação destes verbos que chamou de "verbos de vizinhança". Segundo ele, a justificativa para esta terminologia está na sua significação. De fato, os verbos muqāraba possuem o significado de "estar perto", mas no sentido de "estar prestes a" acontecer algo no sentido temporal, e não no sentido de proximidade física que justifique o termo adotado pelo gramático português. Como sua explanação é bastante reduzida, não é possível ao leitor especializado desfazer o mal entendido gerado. 
Périer (1911, p. 82) escreve um pequeno parágrafo acerca do verbo cas $\bar{a}$, denominado-o como "verbo de possibilidade" a partir de sua tradução. Haywood \& Nahmad (1965, p. 269) falam sobre os verbos 'asā e $k \bar{a} d a$, nesta ordem e sem apresentar sua respectiva terminologia árabe - rajā’e muqāraba. Cowan (2007, p. 173), por sua vez, inclui o verbo $k \bar{a} d a$ nos exemplos dados para explicar o verbo kāna e seus semelhantes, sem nem ao menos discorrer separadamente sobre as diferenças existentes entre estes verbos como explicitado acima.

Corriente (1992, p. 227) inclui estes três grupos de verbos dentro da seção que chamou de "verbos modificadores", subdivididos em três:

a. Verbos "ser" e "tornar-se", em que agrupou kāna e seus semelhantes, bem como os verbos muqāraba (kāda/'awšaka);

b. Verbos incoativos, ou seja, ou verbos $\check{s ̌ u r u}^{\text {; }}$

c. Verbos de possibilidade, isto é, os verbos raja

Com esta classificação e terminologia, acredita-se que o gramático abrangeu a diferenciação semântica entre estes verbos, exceto no grupo a., em que apresenta apenas a tradução literal dos verbos kāda e 'awšaka, sem explicações sintáticas. Ao leitor iniciante pode parecer que tanto os verbos kāda e 'awšaka quanto kāna e seus semelhantes possuem o mesmo uso.

Corriente (1992, p. 228) considera que todos esses verbos listados funcionam como auxiliares e ocupam a posição normal do verbo na sentença, isto é, antecedendo o sujeito ao qual, geralmente, seguirá o verbo principal modificado semanticamente.

O posicionamento sintático dos "verbos modificadores" descrito por Corriente assemelha-se ao descrito por Azeredo (2010, p. 203) para os verbos auxiliares portugueses que, de acordo com a definição terminológica acima, "são aqueles que precedem o verbo principal com a função de exprimir os conteúdos gramaticais", denotando as noções aspectuais (constante, progressiva, incoativa, reiterativa, iterativa) e as atitudes enunciativas (possibilidade, permissão, obrigação, necessidade), como ilustrado nos exemplos abaixo:

(40) A chuva começa a cair forte. (aspecto incoativo)

(41) A chuva está prestes a cair. (aspecto iminente) 
(42) A moça está varrendo o quintal. (aspecto progressivo)

(43) A moça pode varrer o quintal. (possibilidade/permissão)

(44) A moça deve varrer o quintal. (possibilidade/obrigação)

Outro argumento que confirmaria a designação dos verbos árabes em análise pelo termo "auxiliar" encontra-se em Castilho (2010, p. 445), o qual diz que, quando dois verbos ocorrem em adjacência e selecionam o mesmo sujeito, o primeiro verbo é o auxiliar e o segundo é o verbo principal (ou pleno) auxiliado. De fato, nos exemplos (38) e (39), vê-se dois verbos selecionando um único sujeito.

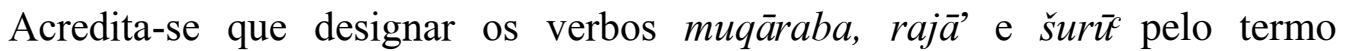
“auxiliar" seja problemático, porque o verbo kāna e seus semelhantes também possuem esta capacidade, isto é, em determinados contextos podem atuar como verbos auxiliares como descrito na seção 7 .

Desta forma, sugere-se que os verbos muqāraba, rajā' e $\check{s} u r \bar{u}$ sejam designados, em português, pelo sintagma terminológico verbos de iminência, de possibilidade e de incoatividade. 


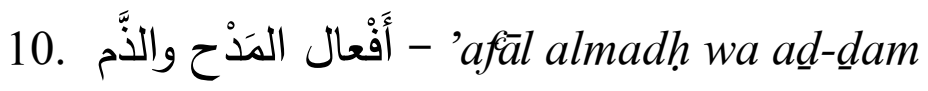

\begin{tabular}{|c|c|c|c|c|c|}
\hline \multicolumn{2}{|c|}{ Termo } & \multicolumn{2}{|c|}{$\begin{array}{c}\text { Possível correspondência } \\
\text { em } \mathrm{Pt}\end{array}$} & \multicolumn{2}{|c|}{ Proposta de padronização } \\
\hline \multicolumn{2}{|c|}{ 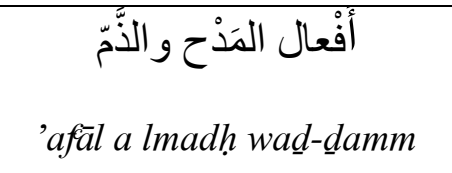 } & \multicolumn{2}{|r|}{$\varnothing$} & \multicolumn{2}{|c|}{ Verbos de elogio e depreciação } \\
\hline \multicolumn{2}{|c|}{$\begin{array}{l}\text { DT: } \\
\text { "Os verbos madh e damm } \\
\text { são verbos invariáveis, } \\
\text { utilizados apenas no } \\
\text { pretérito perfeito para } \\
\text { construir a estrutura de } \\
\text { elogio e depreciação. Cada } \\
\text { estrutura seleciona } \\
\text { obrigatoriamente } \\
\text { atributo de elogio ou } \\
\text { depreciação." } 148\end{array}$} & & & \multicolumn{2}{|c|}{\begin{tabular}{|l} 
TL: \\
1. \\
\\
\\
a.Elogio, louvor; b. \\
\\
repreensãa, crítica, reprovação, \\
vitupério. \\
2. \\
a. Alabanza, loa, elogio; \\
b. censura, reproche, \\
crítica.
\end{tabular}} \\
\hline \multicolumn{2}{|c|}{$\begin{array}{l}\text { Ex.: } \\
\text { nima/ habbad̄ā } \\
\text { bi'sa/ lā habbad̄a }\end{array}$} & & & \multicolumn{2}{|c|}{\begin{tabular}{|l} 
Fonte: \\
1. Sabbagh, 2011, p. $620 /$ \\
\\
320. \\
2. \\
\\
\\
$712 / 270$.
\end{tabular}} \\
\hline \multicolumn{2}{|c|}{$\begin{array}{l}\text { Fonte: } \\
\text { Alhawș, 1987, p. } 216 .\end{array}$} & & & & \\
\hline $\mathbf{P t}_{1774}$ & $\begin{array}{l}\text { Verbos de louvar e } \\
\text { vituperar }\end{array}$ & $\mathbf{E s}_{1992}$ & $\begin{array}{l}\text { Verbos nima/ } \\
\text { ḥabbad̄ā y bi'sa/ lā } \\
\text { ḥabbad̄ā }\end{array}$ & Voc $_{1908}$ & $\begin{array}{l}\text { Verbes de louange et } \\
\text { bláme }\end{array}$ \\
\hline $\mathbf{P t}_{2007}$ & $\begin{array}{l}\text { Verbos nima } \\
\text { (nimat) e bi'sa } \\
\text { (bi'sat) }\end{array}$ & $\mathbf{F r}_{1911}$ & $\begin{array}{l}\text { Verbes de louange et } \\
\text { bláme }\end{array}$ & Dic $_{1973}$ & $\begin{array}{l}\text { Verbs of praise and } \\
\text { blame }\end{array}$ \\
\hline $\operatorname{In}_{1859}$ & $\begin{array}{l}\text { Verbs of praise } \\
\text { and blame }\end{array}$ & $\operatorname{In}_{1965}$ & --- & Dic $_{1983}$ & --- \\
\hline $\mathbf{I n}_{2005}$ & --- & & & & \\
\hline
\end{tabular}

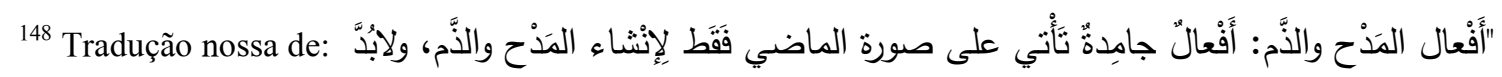

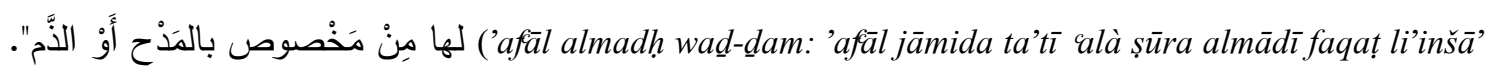
almadh wad-dam wa lā budda lahā min mahșūs bilmadh 'aw ad-dam.) 
De acordo com a tradição gramatical árabe, os termos madh e damm referemse a uma estrutura frasal específica que exalta ou deprecia o sujeito sentencial. Almærī (2002, vol. 8, p.40), por exemplo, utiliza o sintagma terminológico 'uslūb almadh waddamm, literalmente "estilo/ gênero madh e damm”, ao invés de chamá-los unicamente de "verbos", já que os mesmos exigem uma forma particular de emprego.

A definição terminológica presente na ficha acima informa que os verbos madh e damm são invariáveis e conjugam-se apenas no pretérito perfeito. Segundo Alhawș. (1987, p. 216), isto se dá porque estes verbos apresentam-se em um único estilo e indicam um fato, um estado que não exige mudança temporal, ou seja, o elogio ou a depreciação de algo/alguém não necessita da marcação do tempo ou modo.

Os verbos específicos que veiculam a ideia madh e $\underline{d a m m}$ são:

\begin{tabular}{|c|c|c|c|}
\hline Verbos madh & 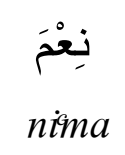 & $\begin{array}{c}\text { حَبَّنّا } \\
h a b b a \underline{d} \bar{a}^{149}\end{array}$ & $\begin{array}{l}\text { "ser bom”, “que } \\
\text { excelente é..." }\end{array}$ \\
\hline Verbos $\underline{d} a m m$ & بَّْسَ & $\begin{array}{c}\text { لا حَبَّذا } \\
\text { lā hִabbada }\end{array}$ & $\begin{array}{c}\text { "ser mau", "que } \\
\text { mau é..." }\end{array}$ \\
\hline
\end{tabular}

Tabela 12: Verbos madh e damm

Estes quatro verbos acima elencados flexionam-se apenas na $3^{a}$ pessoa singular masculina e feminina, embora Corriente (1992, p. 257) afirme que as formas femininas sejam raras e opcionais. Wright (1859, p. 97), por sua vez, salienta que ocasionalmente podem ocorrer as formas verbais de $3^{\mathrm{a}}$ pessoa masculina dual e plural.

O autor supracitado (1859, p. 97) observa ainda que a vocalização original dos verbos nima e bi'sa é, respectivamente, naima e ba'isa. O gramático justifica a mudança vocálica, pautando-se em um fenômeno fonético que abrange os verbos do tipo faila e faula, cuja segunda radical é um fonema faríngeo ou laríngeo. Neste caso, a vogal breve da segunda radical é transferida para a primeira, exatamente como ocorre com os verbos nima e bi'sa ${ }^{150}$.

\footnotetext{
${ }^{149}$ Os verbos habbaḍa e la habbada constituem uma fusão do verbo habba ("fazer-se querido") com o pronome demonstrativo $d \bar{a}$ ("este"). A partícula $l \bar{a}$ anteposta ao verbo corresponde a sua negativa.

${ }^{50}$ As consoantes 'ayn e hamza que ocupam a segunda radical dos verbos nima e bi'sa são classificadas, fonologicamente, como consoante faríngea, fricativa, sonora e consoante laríngea, oclusiva, surda, respectivamente. (Jubran, 2004, p. 23)
} 
Corriente (1992, p. 256) trata destes verbos no capítulo reservado ao estudo das orações exclamativas. Para o gramático espanhol, os verbos madh e $\underline{d} a m m$ servem para exclamar os conceitos de excelência e seu contrário. Tais verbos podem vir seguidos de:

a) Um sujeito determinado:

nima al'ustād $\underline{d} u$. Que bom professor!

bi’sa arrajulu alkādibu. É mau o homem mentiroso.

b) Por um acusativo de especificação ${ }^{151}$ :

bi’sa jawāban. Que resposta má!

c) Por uma subordinada nominalizada por $m \bar{a}$ :

nima mä facalta. Que bem o que você fez!

Cowan (2007, p. 173), após tratar dos verbos de "surpresa e admiração", inclui uma nota modesta a respeito dos verbos nima e bi'sa, sem dissertar acerca de suas características principais.

Embora Périer (1911, p. 82) escreva um reduzido parágrafo, neste há os traços determinantes sobre o tema, bem como os quatro exemplos de verbos que veiculam a ideia madh e damm. O gramático francês selecionado designa estes verbos árabes pelo sintagma terminológico verbes de louange et de bláme.

Dentre os dez autores pesquisados, três deles, a saber, Ryding (2005), Haywood \& Nahmad (1965) e Bakalla et al. (1983) não discorreram sobre os verbos em questão. Os sete autores restantes tocaram no assunto, mesmo que alguns tenham o feito reduzidamente. Cinco dentre estes sete autores, a saber, Abrantes (1774, p. 306), Wright (1859, p. 97), Machuel (1908, p. 56), Périer (1911, p. 82), Cachia (1973, p. 12/59), pautaram sua escolha terminológica na tradução do termo árabe 'afäl almadh wa addam para suas línguas de chegada. Corriente (1992, p. 256) e Cowan (2007, p. 173) optaram por utilizar os principais representantes deste grupo - verbos nima e bi'sa - na tarefa designá-lo.

Acredita-se que a tradução tenha sido opção majoritária, pois não há em português, francês, inglês, nem em espanhol, fatos gramaticais que viabilizassem comparação entre estas línguas e o árabe, com relação a estes verbos específicos.

\footnotetext{
${ }^{151}$ Chamado, em árabe, de تَمَييز tamyīz.
} 
Por isso, sugere-se que seja observada, em língua portuguesa, a tendência seguida pela maioria dos gramáticos e dicionaristas não árabes pesquisados, isto é, que seja adotado o sintagma terminológico verbos de elogio e depreciação a fím de designar o termo árabe 'afäl almadh wa ad-dam. O sintagma terminológico sugerido, pode não remeter a nenhuma comparação gramatical com a língua portuguesa, contudo, é aparente ao leitor especializado brasileiro.

Neste terceiro capítulo, analisaram-se dez termos principais e dezesseis termos secundários, segundo os princípios metodológicos estabelecidos no capítulo anterior. Todos os termos investigados fazem parte do domínio morfossintático do verbo árabe, embora observe-se que determinadas terminologias refletem a mistura de critérios classificatórios originada na designação elaborada pelos primeiros gramáticos árabes.

A padronização terminológica proposta no presente capítulo teve como princípio motivador o público alvo, isto é, o leitor especializado brasileiro. Espera-se que os termos sugeridos sejam aparentes e auxiliem didaticamente o ensino de língua árabe no Brasil. O capítulo seguinte contém a sistematização dos vinte e seis termos organizados em forma de glossário, de acordo com a definição de Barros (2004): uma "lista de unidades terminológicas acompanhadas de seus equivalentes em outras línguas". 


\section{Capítulo IV}

\section{Glossário da Terminologia Verbal Morfossintática}

O glossário ${ }^{152}$ elaborado possui as seguintes características principais:

a. Não apresentar definições;

b. Listar as unidades terminológicas verbais árabes do domínio gramatical morfossintático;

c. Apresentar seus equivalentes em língua portuguesa.

Reitera-se que este glossário terminológico destina-se aos leitores especializados brasileiros, em primeiro lugar, sejam eles pesquisadores ou estudantes de língua árabe. Acredita-se que este material de consulta também seja útil aos leitores especializados de além-mar, visto que, em Portugal, há tradição no estudo da língua árabe devido ao legado linguístico, histórico, cultural deixado por este povo durante os séculos em que estiveram ativamente presentes na Península Ibérica. Espera-se que o produto deste trabalho terminológico possa auxiliar também os arabófonos que tenham a língua portuguesa como objeto de estudo.

Chegou-se ao total de vinte e seis termos árabes, os quais serão listados no glossário árabe-português e organizados considerando sua ordem alfabética árabe. A ordem sistemática foi previamente seguida quando da análise dos mesmos. A disposição dos termos, isto é, sua direção da leitura será, portanto, da direita para a esquerda, segundo a ordem da escrita árabe. O termo principal estará em negrito, sendo seguido por sua transliteração em itálico e pela proposta de padronização em português.

Considerou-se, nos termos árabes compostos, a primeira letra tanto do primeiro vocábulo quanto do segundo a fim de se precisar a ordem alfabética. Não foi levado em consideração o artigo definido $a l$, presente em alguns termos, no momento da ordenação.

\footnotetext{
152 Adotou-se, nesta dissertação, a definição de Barros (2004, p. 144) para o termo "glossário", como mencionado no capítulo I.
} 
Já o glossário português-árabe contará com o termo principal em negrito, que corresponde à proposta de padronização, o equivalente em árabe e sua transliteração em itálico. A ordenação destes verbetes seguirá a ordem alfabética portuguesa.

Passa-se, agora, aos glossários terminológicos: 


\section{Glossário Árabe-Português da Terminologia Verbal Morfossintática}

\begin{tabular}{|c|c|c|}
\hline Verbos com و ou como $2^{a}$ radical & 'ajwaf & أَجَوَف \\
\hline Verbos de elogio e depreciação & 'afäl almadh wad-dam & أَفَعال المَدْح والَّمَ \\
\hline $\begin{array}{l}\text { Verbos de iminência, de } \\
\text { possibilidade e de incoatividade }\end{array}$ & $\begin{array}{l}\text { 'afāl almuqāraba war- } \\
\text { rajā' waš-šurūc }\end{array}$ & أَفْعال المُقارية والَرَّجاء \\
\hline Verbo kāna e seus semelhantes & afcāl nāqișa & أَفْعال ناقصة \\
\hline Triconsonântico simples & sālim & 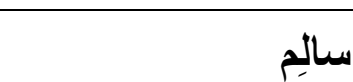 \\
\hline Puramente consonântico & șahịh & \\
\hline Verbo & $f i c l$ & فِعْل \\
\hline Imperativo & fid al'amr & فِعْلَ الأَمْز \\
\hline Intransitivo & lāzim & لازِم \\
\hline $\begin{array}{l}\text { Verbo com duas semiconsoantes } \\
\text { intercaladas }\end{array}$ & lafif mafrūq & تَفْروق \\
\hline $\begin{array}{l}\text { Verbo com duas semiconsoantes } \\
\text { consecutivas }\end{array}$ & lafïf maqrūn & مَقْرون \\
\hline Pretérito Perfeito & mädin & \\
\hline Voz passiva & almabnī lil-majhūl & المَبْني لِلمَجْهول \\
\hline Voz ativa & almabnì lil-maclūm & المَبْنْي لِلمَعْلوم \\
\hline Transitivo & mutacaddin $^{c}$ & مُنَتَدَدٍ \\
\hline Verbos com و ou como $1^{a}$ radical & mițāl & 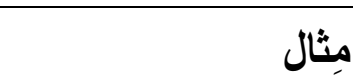 \\
\hline
\end{tabular}




\begin{tabular}{|c|c|c|}
\hline Primitivo & mujarrad & مُجَرَّد \\
\hline Derivado & mazid & 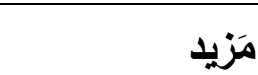 \\
\hline Futuro & mustaqbal & مُسنْتَقْبَلْ \\
\hline Apocopado & muḍāric majzūm & مُضارِع مَجْزوم \\
\hline Presente do indicativo & muḍāric $\operatorname{marf}^{c}$ & مُضارِعِ مَرْفوع \\
\hline Subjuntivo & muḍāric manșūb & مُضارِع مَنْصوب \\
\hline Duplicado & $m u d a^{c c} a f$ & مُضَعَفْتف \\
\hline Consonântico-semiconsonântico & $m u^{c} t a l$ & مُعْتَلَ \\
\hline "Hamzado" & mahmūz & مَهْهوز \\
\hline Verbos com و ou como $3^{a}$ radical & nāqis & ناقِص \\
\hline
\end{tabular}




\section{Glossário Português-Árabe da Terminologia Verbal Morfossintática}

\begin{tabular}{|c|c|c|}
\hline Apocopado & مُضنارِع مَجْزوم & muḍāric majzūm \\
\hline $\begin{array}{l}\text { Consonântico- } \\
\text { semiconsonântico }\end{array}$ & مُعْنَ & $m u^{c} t a l$ \\
\hline Derivado & مَزيد & mazìd \\
\hline Duplicado & مُضَعَََّف & $m u d a^{c c} a f$ \\
\hline Futuro & 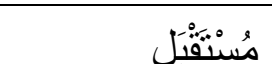 & mustaqbal \\
\hline "Hamzado" & & mahmüz \\
\hline Imperativo & فِعْل الأََْ & fid al'amr \\
\hline Intransitivo & لازِم & lāzim \\
\hline Presente do indicativo & مُضسارِع مَرْفوع & muḍāaric marfiüc \\
\hline Pretérito Perfeito & & mādin \\
\hline Primitivo & مُجَرَّد & mujarrad \\
\hline Puramente consonântico & صَحيح & șaḥihh \\
\hline Subjuntivo & مُضـارِع مَنْصوب & muḍāicic manșūb \\
\hline Transitivo & مُنَعَدٍَِ & mutacaddin $^{c}$ \\
\hline Triconsonântico simples & 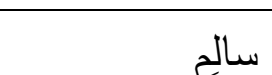 & sālim \\
\hline Verbo & فِعْل & $f i c l$ \\
\hline $\begin{array}{l}\text { Verbo com duas } \\
\text { semiconsoantes consecutivas }\end{array}$ & لفيف مَفْروق & lafif mafrūq \\
\hline
\end{tabular}




\begin{tabular}{|c|c|c|}
\hline $\begin{array}{l}\text { Verbo com duas } \\
\text { semiconsoantes ligadas }\end{array}$ & لفيف مَقْرون & lafï maqrūn \\
\hline Verbo $k \bar{a} n a$ e seus semelhantes & أَفْعال ناقصة & af'āl nāqișa \\
\hline $\begin{array}{l}\text { Verbos com و ou como } 1^{a} \\
\text { radical }\end{array}$ & مِثنال & mitāal \\
\hline $\begin{array}{l}\text { Verbos com و ou como } 2^{a} \\
\text { radical }\end{array}$ & أَجَفَ & 'ajwaf \\
\hline $\begin{array}{l}\text { Verbos com و ou como } 3^{a} \\
\text { radical }\end{array}$ & ناقِص & nāqiș \\
\hline Verbos de elogio e depreciação & أَفْعال المَذْح والَّمَ & $\begin{array}{l}\text { 'afäl almadh } \\
\text { wad-dam }\end{array}$ \\
\hline $\begin{array}{l}\text { Verbos de iminência, de } \\
\text { possibilidade e de incoatividade }\end{array}$ & وأَفْعال المُقاربة والرَّجاء & $\begin{array}{l}\text { 'afäl almuqāraba } \\
\text { war-rajā } \\
\text { waš-šur } \bar{u}\end{array}$ \\
\hline Voz ativa & المَبْني لِلمَعْلوم & $\begin{array}{l}\text { almabnī lil- } \\
\text { maclūm }\end{array}$ \\
\hline Voz passiva & المَبْني للِمَجْهول & $\begin{array}{l}\text { almabnī } \\
\text { majhūl }\end{array}$ \\
\hline
\end{tabular}




\section{Considerações Finais}

Neste trabalho, discutiu-se a terminologia morfossintática do verbo árabe proposta pela teoria gramatical e presente nos manuais contemporâneos de ensino desta língua para nativos e estrangeiros. Revisou-se como este conjunto de termos foi transmitido para quatro línguas modernas - inglês, francês, espanhol e português, por meio da análise de sete gramáticas do árabe escritas por arabistas de nacionalidades diversas e pertencentes a épocas diferentes.

Verificou-se que a terminologia genuína árabe adotada pelos primeiros gramáticos é coerente com cada processo linguístico descrito. Mesmo que no estágo atual da língua não fosse possível identificar o embasamento teórico para determinado termo, a um breve olhar diacrônico desvendavam-se as razões pelas quais os linguístas fizeram tal opção. A título de exemplo, tem-se o termo muḍaric que em tradução literal quer dizer "semelhante, similar". Como esclarecido na nota 86 , este termo foi proposto por Sībawayhi em fins do século VIII, sinalizando a semelhança existente entre este grupo de verbos e os nomes declináveis. Para este gramático, os diacríticos marcadores de caso eram "semelhantes" aos marcadores modais presentes nos verbos mudâric.

Observou-se que, embora os termos adotados pelos gramáticos não árabes em suas línguas maternas sejam fruto de reflexão linguística (conclusão a partir da descrição gramatical de cada autor), todos perpassam o significado literal do termo árabe genuíno, ainda que a tradução não seja o produto final.

Dos vinte e seis termos em análise, constatou-se que dez já possuíam um uso vernáculo padronizado nas línguas abordadas. Oito terminologias já padronizadas foram mantidas em língua portuguesa, por acreditar ser pertinente e aparente ao leitor especializado brasileiro e lusófono em geral. Foi verificada, também, correspondência gramatical entre esses processos linguísticos árabes e portugueses. Os termos padronizados e mantidos são: 


\begin{tabular}{|c|c|}
\hline verbo & fid \\
\hline subjuntivo & mudāaricmanșub \\
\hline futuro & mustaqbal \\
\hline imperativo & fid al'amr \\
\hline intransitivo & lāzim \\
\hline transitivo & mutaaddin \\
\hline voz ativa & mabnī lil-madūm \\
\hline voz passiva & mabnì lil-majhūl \\
\hline
\end{tabular}

Apenas dois termos padronizados não foram mantidos, pois não eram eficientes em demonstrar ao leitor suas diferenças específicas. Foram sugeridos termos aparentes ao público alvo e mais eficientes na tarefa de designar a característica principal destes verbos. Não se observou nenhum item gramatical português que viabilizasse uma correspondência direta ou indireta com ambos os itens árabes. São eles:

\begin{tabular}{c|c}
$\begin{array}{c}\text { verbos com duas semiconsoantes } \\
\text { consecutivas }\end{array}$ & lafíf maqrün \\
\hline $\begin{array}{c}\text { verbos com duas semiconsoantes } \\
\text { intercaladas }\end{array}$ & lafíf mafrū $q$ \\
\end{tabular}

Dos dezesseis termos restantes cujos usos não se encontram padronizados nas quatro línguas de chegada investigadas, cinco apresentam correspondência com processos gramaticais portugueses que propiciaram a sugestão de novos termos direcionados ao leitor especializado brasileiro, tendo como base de contraste a própria língua portugesa. São eles:

\begin{tabular}{|c|c|}
\hline pretérito perfeito & $m \bar{a} \underline{d} \bar{\imath} n$ \\
\hline presente do indicativo & muḍāaic marfüc \\
\hline apocopado & muḍāic majzūm \\
\hline primitivo & mujarrad \\
\hline derivado & mazìd \\
\hline
\end{tabular}


Os últimos onze termos cujos usos não se encontram padronizados e não há possibilidade de correspondência gramatical com o português são:

\begin{tabular}{|c|c|}
\hline puramente consonântico & șaḥhh \\
\hline triconsonântico simples & sālim \\
\hline duplicado & mudacaf \\
\hline "hamzado" & mahmūz \\
\hline consonântico-semiconsonântico & mutal \\
\hline verbos com و ou como $1^{a}$ radical & mițāl \\
\hline verbos com و ou como $2^{a}$ radical & 'ajuaf \\
\hline verbos com و ou $3^{a}$ radical & nāqiș \\
\hline verbo kāna e seus semelhantes & afcāl nāqișa \\
\hline $\begin{array}{l}\text { verbos de iminência, de possibilidade e de } \\
\text { incoatividade }\end{array}$ & $\begin{array}{c}\text { 'afäl almuqāraba war-rajā' } \\
\text { wašs-šurūc }\end{array}$ \\
\hline verbos de elogio e depreciação & 'afäl almadh wad-dam \\
\hline
\end{tabular}

Para os termos acima, duas possibilidades se levantaram: ou algum termo não padronizado, contudo, aparente ao público pretendido foi adaptado em português, ou foi criada uma terminologia nova e específica para o leitor brasileiro cujo interesse de pesquisa e estudo seja a língua árabe.

Considera-se relevante retormar alguns pontos já discutidos ao longo da dissertação. O primeiro deles refere-se à regularidade flexional dos verbos. Todo paradigma flexional árabe é previsto e regular, o que implica variação da raiz é a presença do $w \bar{a} w$ ou $y \bar{a}$, entre as consoantes radicais, bem como o padrão vocálico de determinada forma verbal. Por isso, evitou-se empregar a terminologia "regular" ou “irregular" para as tipologias das raízes verbais.

O segundo ponto relaciona-se às denominadas 'ahruf ak illa, ou "letras fracas". Para os árabes, o $w \bar{a} w$ e o $y \bar{a}$ ' possuem um duplo estatuto funcional. Podem, juntamente ao 'alif, desempenhar o papel das vogais longas, ou compor ao lado das "consoantes fortes" a constituição das raízes verbais e nominais. Em árabe, a dupla função é imediatamente reconhecida na palavra em foco. Os conflitos podem ser gerados nas 
análises não árabes a partir da adaptação de conceitos estrangeiros, como vogal, consoante e semiconsoante/semivogal.

Quanto ao tramento dado às categorias de tempo, modo e aspecto verbal, optou-se pela perspectiva tempo-específica para a padronização das terminologias em português, mesmo concordando que a língua árabe seja genuinamente aspectoespecífica. Há dois motivos preponderantes para esta preferência, o primeiro pauta-se no objeto de estudo desta pesquisa - a língua contemporânea, constantemente influenciada por outras línguas modernas tempo-específicas. O segundo motivo é exatamente a aproximação de conceitos e terminologias do leitor alvo deste trabalho, falante nativo de uma língua cuja categoria de tempo é bem determinada.

Outro ponto a ser retomado refere-se à voz passiva como estratégia de indeterminação do sujeito /agente/ em ambas as línguas. Observou-se que tanto em português como em árabe, a voz passiva do verbo é utilizada com a intenção discursiva de não informar o sujeito /agente/ da ação verbal. Além disso, o árabe demonstra-se semanticamente mais coerente neste quesito, se comparado à língua portuguesa. Diz-se: “o menino nasceu”, utilizando a voz ativa portuguesa e "وُلَدَ الَوَلَدُد wulida alwaladu (lit. “o menino foi nascido"), empregando a voz passiva árabe. O verbo "nascer”, em língua árabe, apresenta-se apenas na voz passiva, pois aquele que nasce será sempre/paciente/.

Não há consenso entre os gramáticos árabes quanto aos "verbos de elogio e depreciação". Alguns não os consideram verbos e sim um "estilo", por serem invariáveis e de uso limitado. No entanto, decidiu-se mantê-los entre os verbos árabes, porque há outros na língua também invariáveis, como o verbo laysa, e porque partiu-se da classificação de manuais árabes voltados ao ensino da língua para estrangeiros, os quais abarcam o estudo destes verbos.

Dicionários bilingues, glossários especializados, entre outras obras de referência são fundamentais no processo de aquisição de uma língua estrangeira e devem ser vistos como obra didática básica (Barros, 2004, p. 73). Por esse motivo, espera-se que este trabalho sirva, ainda que modestamente, de ferramenta didática no ensino do árabe no Brasil e entre a comunidade lusófona interessada no tema, assim como auxilie o estudante no percurso de aprendizagem desta língua cuja a expressividade é inegável no cenário internacional, seja por motivos políticos, 
diplomáticos, comerciais ou simplesmente culturais e linguísticos. Seus falantes nativos ultrapassam a marca de 270 milhões de pessoas, dividas em mais de vinte países, além de ser uma das seis línguas oficiais da ONU, juntamente com o inglês, francês, espanhol, russo e chinês.

Acredita-se ainda que a pertinência deste material alcance os leitores árabes que desejam aprender (ou estejam aprendendo) a língua portuguesa. Há iniciativas governamentais para a implementação do ensino regular de língua portuguesa em alguns países árabes, como, por exemplo, Líbano, Síria, Marrocos, devido à contínua integração destes povos com o Brasil ou Portugal. Foi refletindo sobre esta realidade que se decidiu apresentar a ordem português-árabe dos mesmos termos listados no glossário árabe-português.

A decisão pelo enfoque na classe verbal foi motivada por um interesse particular, mas, sobretudo, pela necessidade de se restringir o escopo desta pesquisa. A importância de se estudar as terminologias gramaticais árabes ultrapassa os limites do verbo. Sugerimos, portanto, que haja prosseguimento neste trabalho terminológico e seja aprofundado e ampliado para as classes dos nomes e das partículas. Gostaríamos que esta pesquisa sirva de ponto de partida para que outros pesquisadores inconformados com a carência de estudos na padronização terminológica desta área, produzam outras ferramentas didáticas para o ensino de árabe no Brasil. 


\section{Referências Bibliográficas}

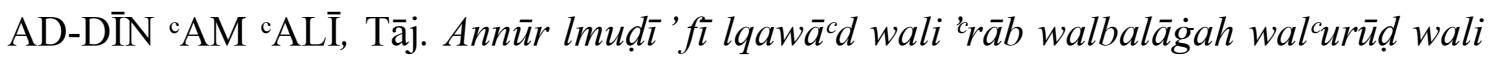
'mlā.' Damasco: Dār lfikr, 2006.

ALHATĪB, Hasām \& JAṬAL, Mușțafā. Allugiatu alcarabiyatu ligaayri almutahașișīn alkitābu al'alwalu. Damasco: Mudīriyat alkutub almaṭbū'āt aljamiyat, 1992-1993.

ALHAAWȘ, 'Aḥmad. Qiṣatu-licrāb, 'uslūb mutațawwir fì-lqawācid wa-licrāb. Damasco: Aț̣abcat arrābicat, 1987.

ALMA'RĪ, Šawqī. Almawsī̄a an-nahawyya lmaysara: biuslūb tacalīmī mutamayazī. Damasco: Dār lhārit, 2002, v. 1-10.

ABRANTES, Fr. António Baptista. Instituições da língua arabiga para o uso das Escolas da Congregação da Terceira Ordem. Lisboa: Regia Officina Typografica, 1774.

AL-KAROURI, AbdulMuneim M. The inflectional morphology of verbs in classical arabic. Khartoum University Press, 1996.

ALMEIDA, Gladis Maria de Barcellos. "O percurso da terminologia: de atividade prática à consolidação de uma disciplina." In: TRADTERM. São Paulo: Humanitas/FFLCH/USP, 2003, v. 9, p. 211-222.

ALVES, Maria Ieda. "Terminologia e neologia." In: TRADTERM. São Paulo: Humanitas/FFLCH/USP, 2003, v. 9, p. 53-70.

AUGUSTO DIAS, Cláudia. "Terminologia: conceitos e aplicações." In: Ci. Inf. Brasília: jan./abr. 2000, v. 29, n.1, p. 90-92.

AZEREDO, José Carlos. Gramática Houaiss da língua portuguesa. São Paulo: Publifolha, 2010, 3. ed.

BAALBAKI, Ramzi. Review of books: Al-Mubarrad's refutation of Sībawayhi and the subsequent reception of the kitāb by Monique Bernards. In: Journal of American Oriental Society. American Oriental Society, v. 119, n. 3, 1999, p. 532-533.

BAALBAKI, Dr. Rohi. Al-Mawrid, A modern Arabic-English dictionary. Beirut: Dar El-Ilm LilMalayin, 1995. 
BACCIN, Paola G. Italianismos na terminologia gastronômica na cidade de São Paulo: um modelo de glossário. Tese de doutoramento. São Paulo: USP, 2003.

BAKALLA, Dr. Muhammad et al. A dictionary of modern linguistic terms: EnglishArabic \&Arabic-English. Beirut: Librairie du Liban, 1983.

BARBOSA, M. Aparecida. "Dicionário, vocabulário, glossário: concepções." In: Constituição da Normalização Terminológica no Brasil/Ieda Maria Alves (org.). São Paulo: Humanitas/FFLCH/CITRAT/USP, 2001, 2. ed., p. 23-45.

BARROS, Lídia A. Curso Básico de Terminologia. São Paulo: Editora da Universidade de São Paulo, 2004.

BECHARA, Evanildo. Moderna gramática portuguesa. Rio de Janeiro: Editora Lucerna, 1999, 37. ed.

BELMOUHOUB, Rachid. Larousse langues orientales. Lire et écrire l'arabe. Paris: Larousse, 2006.

BATESON, Mary Catherine. Arabic language handbook. Washington: Center for Applied Studies, 1967.

BORGES, Marlise F. "Identificação de sintagmas terminológicos em Geociências.” In: Temas de Terminologia/Krieger \& Maciel (org.). São Paulo: Humanitas/FFLCH/USP \& Editora da Universidade/UFRGS, 2001, p.431-433.

BULOS, Afif A. The Arabic triliteral verbs: A Comparative Study of Grammatical Concepts and Processes. Beirut: Khayats, 1965.

CACHIA, Pierre. Dictionary of Arabic grammatical terms, Arabic-English/EnglishArabic. Beirut \& London: Librairie du Liban \& Longman, 1973.

CAMARA, J. Mattoso Jr. Dicionário de linguística e gramática. Petrópolis: Editora Vozes, 1981.

CASTILHO, Ataliba T. de. Nova gramática do português brasileiro. São Paulo: Contexto, 2010, 1. ed.

CINTRA, Anna Maria Marques et al. "Linguagens documentárias e terminologia". In: Constituição da Normalização Terminológica no Brasil/Ieda Maria Alves (org.). São Paulo: Humanitas/FFLCH/CITRAT/USP, 2001, 2. ed., p.17-22.

COMPANY, Houghton M. The american heritage dictionary. Boston: New York, 1991, $2^{\text {nd }}$ College Edition.

CÔRREA, Roberto Alvim. Dicionário escolar francês-português/português-francês. Rio de Janeiro: FENAME/Ministério da Cultura, 1970, 5. ed. 
CORREIA, Margarita. "Neologia e terminologia”. In: Terminologia: questões teóricas, métodos e projectos. Lisboa: Publicações Europa-América, 1998, p. 59-74.

CORRIENTE, F. Dicionario Arabe-Español. Barcelona: Editorial Herder, 1991, Tercera Edicion.

. Gramática Árabe. Barcelona: Editorial Herder, 1992.

COWAN, David. Gramática do árabe moderno: uma introdução/ David Cowan: tradução de Safa A. A. Jubran. São Paulo: Globo, 2007.

DEMAI, Fernanda M. Um dicionário terminológico da área de ortopedia técnica: descrição e análise. Dissertação de Mestrado. São Paulo: USP, 2006.

EL-DAHDAH, Antoine. A pocket dictionary of Arabic grammatical nomenclature. Beirut: Librairie du Liban Publishers, 1997.

FARIA, Ernesto. Gramática superior da língua latina. Rio de Janeiro: Livraria Acadêmica, 1958.

FERREIRA, Aurélio B. H. Novo dicionário da língua portuguesa. Rio de Janeiro: Nova Fronteira, 1986.

FINATTO, Maria José B. "Definição terminológica: fundamentos teóricometodológicos para sua descrição e explicação". In: Temas de Terminologia/Krieger \& Maciel (org.). São Paulo: Humanitas/FFLCH/USP \& Editora da Universidade/UFRGS, 2001a, pp. 434-435.

- "Microestrutura no dicionário terminológico: bases teóricas e orientações metodológicas em direção ao seu tratamento formal”. In: Temas de Terminologia/Krieger \& Maciel (org.). São Paulo: Humanitas/FFLCH/USP \& Editora da Universidade/UFRGS, 2001b, p. 285-296.

GAUDEFROY-DEMOMBYNES, M. \& BLACHÈRE, R. Grammaire de L'Arabe Classique. Paris: Librairie Orientale et Américaine, 1937.

GOMES, Elias M. Mil e um verbos árabes: uma proposta lexicográfica. Dissertação de Mestrado. São Paulo: USP, 2011.

HAYWOOD, J. A. \& NAHMAD, H. M. A new Arabic grammar of written language. London: Lund Humphries, 1965.

HOUAISS, Antônio. Dicionário eletrônico Houaiss de língua portuguesa. Rio de Janeiro: Editora Objetiva, 2007.

HOURANI, Albert. Uma história dos povos árabes. São Paulo: Companhia das Letras, 2001. 
JUBRAN, Safa Abou-Chahla. "Para uma romanização padronizada de termos árabes em textos de língua portuguesa." In: Tiraz. USP, Ano 1 (2004). São Paulo: Humanitas/FFLCH/USP, 2004, p. 16-29.

- Árabe e Português: Fonologia Contrastiva. São Paulo: Edusp/Fapesp/CEAR, 2004.

KATAMBA, Francis. Modern linguistics morphology. London: Macmillan Press, 1994.

KELLY, Page H. Hebraico Bíblico: uma gramática introdutória./ Page Kelly; tradução de Marie Ann Wangen Krahn. São Leopoldo, 1998, 7. ed.

KRIEGER, Maria da Graça; \& FINATTO, Maria José Borcorny. Introdução à terminologia: teoria e prática. São Paulo: Contexto, 2004.

KRIEGER, Maria da Graça. “A face linguística da Terminologia.” In: Temas de Terminologia/Krieger \& Maciel (org.). São Paulo: Humanitas/FFLCH/USP \& Editora da Universidade/UFRGS, 2001, p. 22-32.

KRIEGER, Maria da Graça. "O termo: questionamentos e configurações." In: TRADTERM. São Paulo: Humanitas/FFLCH/CITRAT/USP, 2001, n. 7, p.111140.

KRIEGER, Maria da Graça. "Sobre Terminologia e seus objetos”. In: Temas de Terminologia/Krieger \& Maciel (org.). São Paulo: Humanitas/FFLCH/USP \& Editora da Universidade/UFRGS, 2001, p. 34-38. . "Terminologia revisitada." In: Temas de Terminologia/Krieger \&

Maciel (org.). São Paulo: Humanitas/FFLCH/USP \& Editora da Universidade/UFRGS, 2001, p. 47-60.

LIMA, Rocha. Gramática normativa da língua portuguesa. Rio de Janeiro: José Olympio Editora, 2002, 42. ed.

LIPIŃSKI, Edward. Semitic languages, outline of a comparative grammar. Leuven: Peeters, 1997.

LOGUERCIO, Sandra D. "Da falta de equivalência à paráfrase." In: Temas de Terminologia/Krieger \& Maciel (org.). São Paulo: Humanitas/FFLCH/USP \& Editora da Universidade/UFRGS, 2001, p. 415-421.

MACIEL, Anns Maria Becker. "Pertinência pragmática e nomenclatura de um dicionário terminológico." In: Temas de Terminologia/Krieger \& Maciel (org.). São Paulo: Humanitas/FFLCH/USP \& Editora da Universidade/UFRGS, 2001a, p. 275-284. 
MACIEL, Anns Maria Becker. "Terminologia, linguagem de especialidade e dicionários." In: Temas de Terminologia/Krieger \& Maciel (org.). São Paulo: Humanitas/FFLCH/USP \& Editora da Universidade/UFRGS, 2001b, p. 39-46.

MCCARTHY, John J. Formal problems in semitic phonology and morphology. Doctoral dissertation (1979), MIT (distributed by IULC, republished New York. Garland, 1982b).

MACHUEL, L. Principaux termes techniques de la grammaire Arabe. Tunis : Société Anonyme d'Imprimerie Rapide, 1908.

MOHAMMAD, Mahmoud Dawood. The semantics of tenses and aspects in English and Modern Standard Arabic. Dissertation submitted to the Faculty of the Graduate School of Georgetown University in partial fulfillment for the degree of Doctor of Philosophy in Applied Linguistics. Washington: 1982.

MOURA, Denilda (org.) Os múltiplos usos da língua. Maceió : EdUFAL.

OWENS, Jonathans. "Models for interpreting the development of Medieval Arabic Grammatical Theory." In: Journal of the American Oriental Society. v. 111, No 2 (Apr. - Jun., 1991) p. 225-238.

PAIVA, Maria Helena. "Unidades monoverbais e pluriverbais, diacronia e tratamento informático no corpus metalinguístico do português quinhentista.” In: Revista de Estudos Linguísticos da Universidade do Porto. v. 1, 2006, p. 107-142.

PÉRIER, Augustin. Nouvelle grammaire Arabe. Paris: Editeur Ernest Leroux, 1911.

PERINI, Mário A. Gramática descritiva do português. São Paulo: Editora Ática, 2003.

PIETROFORTE, Antônio V. S. \& LOPES, Ivã C. “A semântica lexical.” In: Introdução à Linguística II: princípios de análisel José Luiz Fiorin (org.). São Paulo: Contexto, 2003, p. 111-135.

ROMAN, André. Grammaire de l'arabe. Paris: Presses Universitaires de France, 1990.

RYDING, Karin C. A Reference Grammar of Modern Standard Arabic. New York: Cambridge University Press, 2005.

SABBAGH, Alphonse Nagib. Dicionário Português-Árabe. Beirut : Librairie du Liban Publishers, 2004.

SABBAGH, Alphonse Nagib. Dicionário Árabe-Português. Rio de Janeiro: Ministério da Cultura, Fundação Biblioteca Nacional \& Almádena Editora, 2011.

SAUSSURE, F. Curso de Linguística Geral. São Paulo: Cultrix, 2006, 27.ed. 
SCHRAMM, Gene. “An outline of Classical Arabic Verb Structure.” In: Linguistic Society of America. Language, v. 38, n. 4, (Oct - Dec 1962), p. 360-375. Disponível em: <www.jstor.org/stable/410672>. Acesso em 18 mar. 2010.

SILVA, Eloiza Teresinha F. da. Dicionário técnico bilíngue inglês-português da subárea do Check-list. Dissertação de Mestrado. São Paulo: USP, 2009.

SILVA, Thaïs Cristófaro. Fonética e Fonologia do Português: roteito de estudos e guia de exercícios. São Paulo: Contexto, 2001, $4^{\mathrm{a}} \mathrm{ed}$.

SMART, J.R. Arabic. UK: Teach yourself books, 1986.

SOUSA, Fr. João de. Vestigios da lingua arabica em Portugal, ou Lexicon Etymologico das palavras, e nomes portuguezes, que tem origem arabica. Lisboa: Officina da Academia Real das Sciencias, 1789.

SUBHI, Hamawi (compilação). Al-Munjed fi-Luğat al- ${ }^{\circ}$ Arabyyiat al-Mưāșirat. Beirut: Dār al-Mašriq, 2001, 2a edição.

VARGENS, João Baptista M. \& CAFFARO, Paula da C. (org.). Arabismo: um tema e suas representações no Brasil e em Portugal. Rio Bonito: Almádena, 2010.

VERSTEEGH, Kees. Landmarks in linguistic thought III: The Arabic Linguistic Tradition. London and New York: Routledge, 1997.

. "Linguistic Contacts between Arabic and Other Languages." In: Arabic, T. 48, Fasc. 4, Linguistique Arabe: Sociolinguistique et Histoire de la Langue. Brill, 2001, p. 470-508.

. "The Arabic Terminology of Syntactic Position.” In: Arabia, T. 25, Fasc. 3, Brill, 1978, p. 261-281.

VON KEMNITZ, Eva-Maria. Portugal e o Magrebe (séculos XVIII/XIX). Pragmatismo, inovação e conhecimento nas relações diplomáticas. Portugal: Colecção Biblioteca Diplomática do MNE - Série D \& Ministério dos Negócios Estrangeiros, 2010.

ZEKRI, Mostafa \& BAPTISTA, Jorge. Manual de Iniciação ao Árabe. Portugal: Serviços Gráficos da Universidade do Algarve, 2002. 
WEHR, Hans. A dictionary of modern written Arabic. New York: Spoken Language Services Inc, 1976, $3^{\text {rd }}$ edition.

WIGHTWICK, Jane \& GAATAR, Mahmoud. Verbs and Essentials of Grammar. New York: MacGraw Hill, 2008.

WRIGHT, William. A grammar of the Arabic language. London: Convent Garden, v. I (1859) e v. II (1862) 